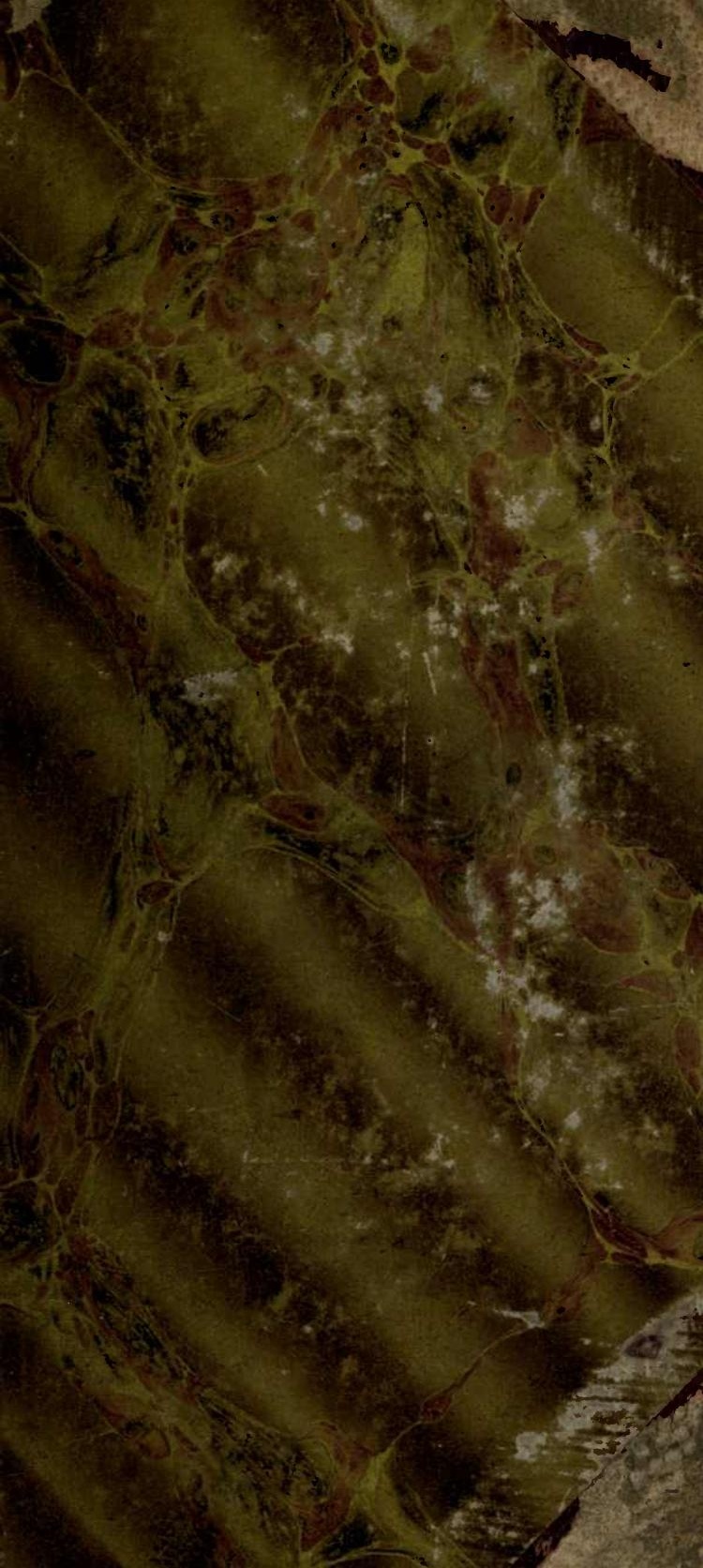




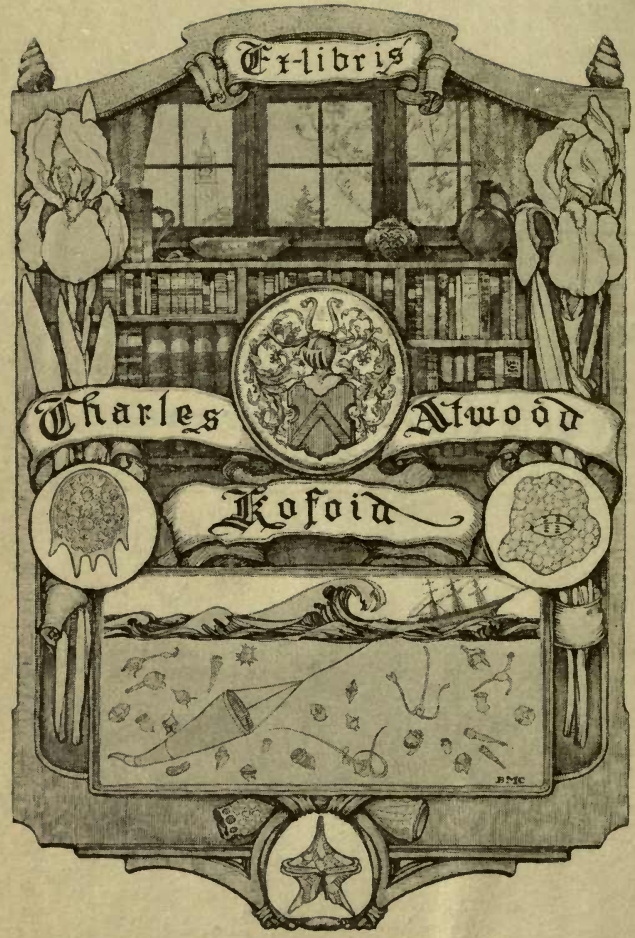




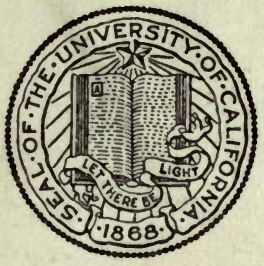

THE LIBRARY $\mathrm{OF}$

THE UNIVERSITY OF CALIFORNIA

\author{
PRESENTED BY
}

PROF. CHARLES A. KOFOID AND

MRS. PRUDENCE W. KOFOID

\title{
PALEONTOLOGY LIBRARY
}

\author{
IEARTH \\ SCIENCES \\ LIBRARY
}




\section{7.}

F
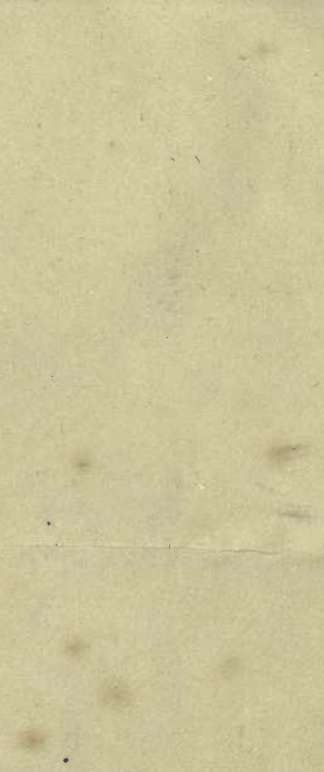

a

.

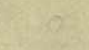






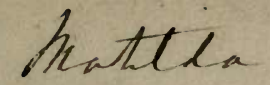

Abxonden

\title{
CATALOGUE
}

\author{
OF \\ MARINE POLYZOA \\ IN
}

THE COLLECTION

OF THE

BRITISH MUSEUM.

. PART II.

CHEILOSTOMATA (PART.).

LONDON:

PRINTED BY ORDER OF THE TRUSTEES.

1854. 


\section{Gift of C. A. Kofoid}

\section{PALEONTOLOGY LIBRARY}

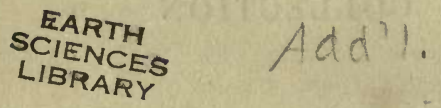

PRINTED BY TAYLOR AND FRANCIS, RED LION COURT, FLEET STREET. 


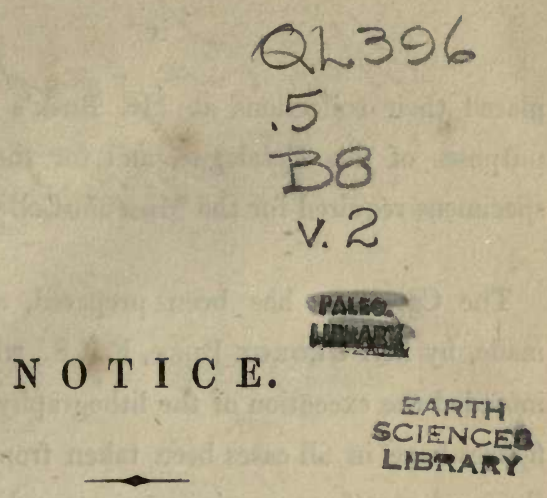

IN the present Catalogue it is intended to comprise figures and descriptions of all the species of Marine Polyzoa in the Collection of the British Museum, and from typical specimens therein contained.

This Collection, already valuable, especially in the possession of Dr. Johnston's specimens, has recently been materially augmented by the addition of numerous Australian and other forms, many of them new, procured by Mr. J. Macgillivray, on the voyage of H.M.S. Rattlesnake. It has also been much enriched by the liberality of Charles Darwin, Esq., F.R.S., Dr. J. Hooker, F.R.S., Dr. Lyall, R.N., R. M‘Andrew, Esq., F.R.S., J. S. Bowerbank, Esq., F.R.S., The Rev. David Landsborough, Mrs. Gatty, Miss Cutler, Professor Edward Forbes, F.R.S., Dr. Greville, J. Hyndman, Esq., Joshua Alder, Esq., Dr. W. Stanger, the late W. Thompson, Esq., of Belfast, and others, who have 
placed their collections at Mr. Busk's disposal, for the purposes of this Catalogue, and for the selection of the specimens required for the Museum Collection.

The Catalogue has been prepared, and the drawings made, by Mr. George Busk, F.R.S., who has also superintended the execution of the lithography. The magnified figures have in all cases been taken from nature, and for the most part from specimens preserved in fluid, in order to ensure a more natural aspect than that afforded by dried specimens. As they have been drawn with the aid of the camera lucida, and to a scale which is given with each plate or figure, the absolute and relative proportions of the different objects will be at once obvious.

JOHN EDWARD GRAY.

1 Dec. 1853. 


\section{LIST OF SPECIES.}

Family 10. Membraniporida ...... Page

Gen. 1. Membranipora ............. 56

1. M. membranacea.......... 56

2. M. pilosa.............. 56

3. M. coriacea ........... 57

4. M. umbonata ........... 57

5. M. lineata $\ldots \ldots \ldots \ldots \ldots \ldots, 58$

6. M. Flemingii $\ldots \ldots \ldots \ldots \ldots, 58$

7. M. Rozieri ........... 59

8. M. Rosselii ............ 59

9. M. calpensis .......... 60

10. M. stenostoma ......... 60

11. M. cervicornis ........... 60

12. M. Lacroixii........... 60

13. M. cyclops ............. 61

14. M. monostachys ......... 61

15. M. magnilabris $\ldots \ldots \ldots \ldots \ldots$. 62

16. M. galeata $\ldots \ldots \ldots \ldots \ldots, 62$

Gen. 2. Lepralia ................ 63

* Armatx.

1. L. Brongniartii ......... 65

2. L. Landsborovii .......... 66

3. L. galeata $\ldots \ldots \ldots \ldots \ldots, 66$

4. L. reticulata $\ldots \ldots \ldots \ldots \ldots, 66$

5. L. marionensis.......... 67 
6. Lepralia auriculata

7. L. concinna............. 67

8. L. verrucosa............ 68

9. L. violacea ........... 69

10. L. spinifera ............ 69

11. L. trispinosa $\ldots \ldots \ldots \ldots \ldots .70$

12. L. coccinea ........... 70

13. L. linearis $\ldots \ldots \ldots \ldots \ldots \ldots 71$

14. L. alata ............ 71

15. L. monoceros .......... 72

16. L. bicristata........... 72

17. L. margaritifera ......... 72

18. L. ciliata ............. 73

19. L. Gattyæ ............ 73

20. L. Hyndmanni $\ldots \ldots \ldots \ldots .74$

21. L. personata .......... 74

22. L. depressa ........... 75

23. L. Lyallii .............. 75

** Inarmatæ.

24. L. variolosa ............ 75

25. L. nitida ............ 76

26. L. annulata ........... 76

27. L. bispinosa........... 77

28. L. Peachii ........... 77

29. L. ventricosa .......... 78

30. L. melolontha .......... 78

31. L. innominata .......... 79

32. L. punctata ........... 79

33. L. figularis $\ldots \ldots \ldots \ldots \ldots \ldots \quad 80$

34. L. pertusa $\ldots \ldots \ldots \ldots \ldots \ldots \quad 80$

35. L. pallasiana .......... 81

36. L. cucullata ............ 81

37. L. labiosa............ 82

38. L. labrosa $\ldots \ldots \ldots \ldots \ldots \ldots \quad 82$

39. L. simplex .......... 82

40. L. areolata ........... 82

41. L. adpressa ........... 82

42. L. Malusii $\ldots \ldots \ldots \ldots \ldots \ldots 83$

43. L. granifera ........... 83

44. L. hyalina $\ldots \ldots \ldots \ldots \ldots \ldots 84$

45. L. discreta ........... 85

46. L. annularis $\ldots \ldots \ldots \ldots \ldots 85$ 
Fam. 11. Celleporide................... 85

Gen. 1. Cellepora ................ 85

* Adnate.

1. C. pumicosa............ 86

2. C. Hassallii ............ 86

3. C. vitrina ............. 87

4. C. bispinata.............. 87

5. C. mamillata .......... 87

** Erect.

6. C. ramulosa............ 87

7. C. Skenei.............. 88

8. C. fusca ............. 88

Fam. 12. Escharidat................... 88

Gen. 1. Eschara................. 89

1. E. foliacea ............ 89

2. E. contorta ............ 89

3. E. urceolata ............. 90

4. E. platalea ............. 90

5. E. lichenoides ........... 90

6. E. fuegensis............ 90

7. E. decussata ........... 91

8. E. flabellaris $\ldots \ldots \ldots \ldots \ldots, 91$

9. E. gracilis ............. 91

10. E. gigantea ........... 91

11. E. cervicornis .......... 92

Gen. 2. Retepora $\ldots \ldots \ldots \ldots \ldots \ldots \ldots . \ldots 9$

1. R. cellulosa ............. 93

2. R. beaniana............. 94

3. R. phœnicea ........... 94

Fam. 13. Vinculariad

Gen. 1. Vincularia................ 96

1. V. ornata............ 96 
Fam. 14. Selenariade................ Page 97

Gen. 1. Cupularia .............. 97

1. C. guineensis $\ldots \ldots \ldots \ldots \ldots .98$

2. C. Owenii $\ldots \ldots \ldots \ldots \ldots \ldots 99$

3. C. Lowei ............ 99

4. C. stellata $\ldots \ldots \ldots \ldots \ldots \ldots 99$

5. C. pyriformis ......... 100

Gen. 2. Lunulites ................. 100

1. L. gibbosa ............ 100

2. L. capulus ........... 100

3. L. philippinensis......... 101

4. L. cancellata .......... 101

Gen. 3. Selenaria ............... 101

1. S. maculata ............ 101 


\title{
CATALOGUE
}

\author{
OP \\ MA R I E POLYZOA.
}

Fam. 10. Membraniporid E.

Char. Polyzoary membranaceo-calcareous or calcareous, expanded, encrusting, sometimes foliaceous, contorted and suberect. Cells horizontal, quincuncial or serial.

Flustra, Linn.

Flustradx, Gray, Cat. B. M. 145, 1848.

Celleporidæ (part.), Johnston, Brit. Zooph. ed. 2. p. 263.

Sy nopsis of Genera.

* Cells more or less open in front, with raised margins.

1. Membranipora.

** Cells disposed in a radiate manner; closed in front.

2. LePralia. 


\section{Membranipora.}

Polyzoary encrusting or suberect, foliaceous and contorted, spreading irregularly. Cells more or less irregularly disposed or quincuncial, with raised margins; a greater or less extent of the front membranaceous and flexible.

Eschara (part.), Pallas, Elench.

Flustra, Linn., Müller, Esper, Berkeley, Lamarck (part.), Grant, Fleming (part.), Risso, Johnston, Transact. Newc. Soc. ii. Lamouroux, Hist. d. Pol. p. 96 (part.).

Membranipora, Johnston, B.Z.; W. Thompson; Hassall.

Discopora (part.), Lamarck, An. s. V. ii. 248, 1836.

Annulipora, Gray, App. B. R.

Conopeum, Gray, App. B. R.

Callopora, Gray, App. B. $R$.

Amphiblestrum, Gray, App. B. R.

Micropora, Gray, App. B. R.

1. Membranipora membranacea. Pl. LXVIII. fig. 2. Cells oblong, with a short blunt spine at each upper angle.

Flustra membranacea, Linn. Syst. 1301 ; Fabric. Faun. Grœnl. 437 ; Müller, Zool. Dan. Prod. 253; Ellis \& Soland. Zooph. 18; Fleming, Brit. Anim. 536; Johnston in Trans. Newc. Soc. ii. 265 ; Blainville, Actinol. 450 ; Couch, Zooph. Cornw. 55 ; Corn. Faun. iii. pl. 2l. fig. 2; O. Fabr. Faun. Grœnl. p. 437. n. 446.

Flustra telacea, Lam. Anim. s. Vert. ed. 2. ii. 223 (not F. memb. p. 225).

Membranipora membranacea, Blainv. Actin. 447.

$H a b$. European Seas : common, spreading on fucus, sometimes suberect or free.

\section{Membranipora pilosa. Pl. LXXi.}

Cell prolonged below. A movable spine or vibraculum below the lower margin of the aperture, sometimes aborted; an irregular number of marginal spines. Wall of cell cribriform.

Irregular spongy foliaceous Coralline, Ellis, Corall. 73. no. 4. pl. 31 .

Eschara pilosa, Pallas, Elench. 50; Moll, Seerinde, p. 41. pl. 1 \& 2. figs. 5 \& 6 .

Flustra pilosa, Linn. Syst. 1301; Müll. Zool. Dan. Prod. 253 ;

Ellis and Soland. Zooph. 13; Esper, Pflanz. Flust. t. 4. figs. 1, 2 ; Berk. Syn. i. 214; Lamk. Anim. s. Vert. ii. 159, ed. 2. ii. 224 ; Blainv. Dict. Sc. Nat. 1x. 415; Grant, Edin. New Phil. Journ. iii. 111 ; Flem. Brit.Anim. 537 ; Risso, L'Europ. Mérid. 
v. 335 ; Johnst. Trans. Newc. Soc. ii. 265. pl.9. fig. 5 ; Lister, Phil. Trans. 1834, 384. pl. 12. fig. 2 ; Templeton, Mag. Nat. Hist. ix. 469.

Membranipora pilosa, Johnst.Brit.Zooph.280. pl.34. figs. 10-12; Couch, Corn. Faun. iii. 119; Van Beneden, Recherch.53. figs. 1-10; Johnst. Hist. Brit. Zooph. ed. 2. 327. t. 56. fig. 6.

Flustra dentata, Ellis and Soland. Zooph. 15; Turt. Brit. Faun. 209 ; Lamk. Hist. Anim. s. Vert. ii. 158, ed. 2. ii. 224 ; Templeton, Mag. Nat. Hist. ix. 469.

Flustra lineata, Esper, Pflanz. Flust. t. 6 (? not good).

Membranipora pilosa, Farre, Phil. Trans. 1837, 412. t. 27. figs. $1-5$.

Membranipora pilosa var. $\beta$, Johnst. Brit. Zooph. 327.

Eschara millepora, Ellis, Corall.t.29. fig. D; Ellis, Phil. Trans. abridg. x. 492. t. 12. fig. $4 \mathrm{D}$.

Membranipora stellata, W. Thompson, Ann. Nat. Hist. v. 101 ; Hassall, Ann. Nat. Hist. vii. 369.

Annulipora pilosa, Gray, List Brit. Rad.p. 107.

Annulipora dentata, Gray, List Brit. Rad. p. 107.

$H a b$. European Seas; on Laminariæ and many other sea-weeds, very common.

When encrusting very slender fuci, it much resembles the Electra verticillata of Lamouroux, H.d. Polypes, p. 120 ; and is $F$. pilosa, var. $\gamma$. reaumuriana of Moll. (l.c. p. 46 . fig. $6 \mathrm{~A}-\mathrm{H})$.

3. Membranipora coriacea. Pl. LXXIII. figs. 4, 5.

Front of cells broadly elliptical ; margin elevated into a small tuberosity on each side of the base of the mouth. Anterior surface punctate. Ovicells with a projection in front.

Flustra coriacea, Esper, Pflanz. Flust. t. 7. fig. 2 ; Johnst. Hist. Brit. Zooph. ed. 2. p. 349. t. 56. fig. 8.

Discopora coriacea, Lamk. Hist. ed. 2. ii. 251; Lamx. Encyc. 255; Blainv. Dict. Sc. Nat. 1x. 411 ; Man. Act. 446.

Micropora coriacea, Gray, List Brit. Rad. p. 115.

$H a b$. European Seas; encrusting shells.

4. Membranipora umbonata. Pl. LXXIII. figs. 6, 7 .

Front of cell broadly elliptical; margin scarcely raised. A spine on each side of the mouth. A projecting avicularium on the front of the cell.

$H a b$. Van Diemen's Land; on fucus. Mrs. Smith, from $W$.

Thompson.

The very prominent umbonate avicularium on the front of the cell suffices to distinguish this species of Membranipora. The 
figure in Plate LXXIII. is not good, as it is drawn from a specimen apparently without the oral spines, which usually exist in and are in fact a prominent characteristic of the species. The margin of the cells is scarcely raised, except in the older ones in the centre of a patch, and the disposition towards a radiating arrangement of the cells approximates this species, perhaps too closely, to Lepralia.

\section{Membranipora lineata. Pl. LXI. fig. 1.}

Cells oval, separate, the margin armed with numerous slender spines, erect or bent inwards.

Flustra lineata, Linn. Syst. 1301; Müll. Zool. Dan. Prod.253; Fabr. Faun. Grænl.437 ; Jameson, Wern. Mem. i. 563; Couch, Zooph. Cornw. 55; Corn. Faun. iii. 124; W. Thompson, Ann. Nat. Hist. v. 253; Johnst. Hist. Brit. Zooph. ed. 2. p. 349. t. 66 . fig. $4, \&$ p. 350 .

Flustra spinifera, Johnst. Trans. Newc. Soc. ii. 266. pl. 9. fig. 6. Flustra hirta, Lamour. Corall. 111 ; Bosc, Vers, iii. 119 ; Risso, L'Europ. Mérid. v. 334.

Callopora lineata, Gray, List Brit. Rad.p. 109.

$H a b$. European Seas; common; and according to Lamouroux it also occurs in Greenland, on stones, shells and fuci.

Although some forms of Lep. nitida occasionally present a considerable resemblance to this species, there can be no doubt of their being perfectly distinct.

6. Membranipora Flemingil. Pl. LXI. fig. $2 . \quad$ Pl. LXXXIV. figs. 4, 5, 6 . Pl. CIV. figs. 2, 3, 4.

Front of cell ovate, very broad below ; margin thick, granular ; front of cell partially filled in by a calcareous, granular expansion. A projecting avicularium on each side below the margin of the aperture, or sometimes one, in the centre; $0-2-7$ spines on the upper margin of aperture. Ovicell galeate.

Flustra mernbranacea, Müll. Zool. Dan. Prod. 253. no. 3054; Zool.Dan. iii. 63. t. 117. figs. 1, 2; Fabr. Faun. Grœnl. 437; Lamour. Corall. 47; M.-Edw. Lamk. Hist. ed. 2. ii. 225; Blainv. Man. Act. 450.

Membranipora membranacea, Johnst. Hist. Brit. Zooph. ed. 2. p. 328.t.56. fig. T, \& p. 478; not Blainv. Dict. Sc. Nat. 412.

Flustra unicornis, Flem. Edin. Phil. Journ. ii. 87; Flem. Brit. Anim. 236; Blainv. Act. 450 ; Johnst. Tr. Newc. Soc. ii. 266. Membranipora unicornis, Blainv. D. S. N. Ix. 412; Man. Act. 447.

Flustra tuberculata, Johnst. Br. Zooph. 289; Bosc, Vers, iii. 143. 
Flustra Peachii, Couch, Rep. Cornw. Polytechnic Soc. 81 (see Johnst. Brit. Zooph. 478). Amphiblestrum membranaceum, Gray, List B. R. 110. $H a b$. European Seas; Australia? : on stones and shells.

The above synonyms are assigned to this species chiefly on the authority of Dr. Johnston, but several of them are probably erroneous. No species presents greater diversities of form than the present; and specimens will occasionally be met with, especially from deep water, in which, from the almost entire absence of the spines and avicularia, great difficulty will be experienced in the determination; careful inspection, however, of various parts of the patch, especially at the growing edge, if it be in the growing state, will usually suffice to trace its relationship to the form assumed as the type of the species. The figures given in the different plates referred to, afford but a faint notion of the endless varieties induced by age, wear and situation, particularly as to depth, of this protean form. I have ventured to assign a new term to it, because the specific name ' membranacea' belongs, as I think, of priority, to another species; and Dr. Fleming's name, 'unicornis,' is so inapplicable that its retention seems scarcely justifiable.

\section{Membranipora Rozieri. PI. LXV. fig. 6.}

Front of cell elliptical ; mouth orbicular, with a raised margin and small tuberosity on each side ; an oval or elongated opening on each side of the front of the cell immediately below the mouth. Ovicell globose, carinate in front.

Flustra Rozieri, Audouin, Savigny, Egypt. pl. 8. fig. 9. $H a b$. Rio de Janeiro, Darwin. On fucus.

Notwithstanding the above habitat, from which only have I seen a specimen, collected by Mr. Darwin, there can be no doubt of the identity of the form with that so beautifully figured by Savigny.

\section{Membranipora Rosselit. Pl. C. fig. 2.}

Front of cells oval, wide, or elongated; the lower half of the area filled in by a calcareous granulated expansion; margin finely beaded. Ovicell flattened in front.

Flustra Rosselii, Audouin, Expl. 240; Savigny, Egypt.pl. 10. fig. il.

Hab. Orkney. Coast of Devon (Start)?, Bowerbank. Bay of Gibraltar, $M^{*}$ Andrew, Landsborough. 
9. Membranipora calpensis, n. sp.? Pl. CIV. figs. 5, 6.

Front of cell oval, elongated ; margins elevated, smooth ; anterior surface of cell punctate.

$H a b$. Bay of Gibraltar, M'Andrew, Landsborough. Egean Sea,

$E$. Forbes. On fuci, shells and stones, and sometimes scarcely attached to anything.

A fine and, apparently, abundant species which I am unable positively to reconcile with any published description, and therefore venture to assign a name to. It seems at present to be confined to the Mediterranean, but no figure at all approaching it occurs among those of Savigny, unless it be that of Flustra Latreillei, pl. 14. fig. 8 .

10. Membranipora stenostoma, n. s. Pl. C. fig. 1.

Front of cell pyriform ; margins elevated, smooth, not grooved; surface of cell smooth, or subgranular, a long spine on each side of the mouth, which is very narrow. Avicularia scattered over the polyzoary; mandible triangular acute.

Hab. Tasmania, Mrs. Smith (W. Thompson). East Falkland Islands, 4 to 10 fathoms, Darwin.

11. Membranipora cervicornis, n. s. Pl. C. fig. 3.

Front of cell oblong or oval; a strong and much-projecting process arising from each upper angle of the aperture, branching like a stag's horn and bending over the front of the cell, usually meeting and inosculating; several other simple or forked, marginal spines. Ovicell galeate, crowned with a small avicularium? Hab. —?

This very curious species is at once distinguishable by the processes on each side of the upper part of the cell, which, projecting at a right angle, branch out in the manner of the antlers of a stag, and usually uniting in front by one or more of the branches, cover and protect the open front of the cell in a very effectual manner. The colour of the polyzoary is purplish.

12. Membranipora Lacroixir. Pl. LXIX. Pl. CIV. fig. I.

Front of cell oval, either entirely occupied by a membrane, or partially filled in by a calcareous, granulated expansion all round the circumference, but wider inferiorly; margin granulated; usually an avicularium on either side below the aperture, and occasionally a marginal spine (usually obsolete or worn off) on each side above. 
Flustra distans, Hassall, Ann. Nat. Hist. vii. 369; Johnst. Brit. Zooph. 350. pl. 57. figs. 11, 12.

? Flustra hibernica, Hassall, Ann. \& Mag. Nat. Hist. vi. 172. t. 7 . fig. 1 ; vii. 370 .

? Lepralia pedilostoma, part., Johnst. Brit. Zooph. 315.

Membranipora membranacea?, Johnst. Brit. Zooph. 350.

Flustra Peachii, Couch, 9th Rep. Cornw. Polyt. Soc. 81.

Flustra Lacroixii, Savigny, Egypt. t. 10. fig.9.

Flustra Savartii, Aud. Exp. i. 240; Savigny, Egypt. t. 10. fig. 10. Membranipora Peachii, Couch, Corn. Faun. iii. 120. t. 22. fig. 13. Conopeum reticulum, Gray, List Brit. Rad. p. 108.

$\mathrm{H} a \mathrm{~b}$. European Seas, common, spreading like a network over stones and dead shells. It occurs (?) also in Australia.

This species, the identity of which with the Millepora reticulum of Esper may be doubted, and which is certainly distinct from what is described as Discopora reticulum in Lamarck (Hist. ii. 250. ed. 2), and probably therefore from the Membranipora reticulum of Blainville (Man. d'Actinol.447), is indubitably the same with Flustra Lacroixii, Audouin, and apparently also with the succeeding figure of $F$. Savartii ; and I have therefore, in the uncertainty of the older appellation of Esper, and at the same time to avoid confusion with those of Lamarck and Blainville, adopted that of Audouin, as the next in order of time, to the exclusion of Dr. Hassall's name of $F$. distans, and Mr. Couch's of F. Peachii, both of which doubtless refer to one and the same species.

\section{Membranipora cyclops, n. s. Pl. LXV. fig. 3 .}

Front of cells oval; margin very much raised, beaded; a single avicularium below the aperture.

$H a b$. New Zealand. On fucus.

Very much like the preceding, but differing in the single instead of two avicularia below the aperture.

\section{Membranipora monostachys, n. s. Pl. LXX.}

Cells distant in the younger portions of the polyzoary, attenuated downwards, and disposed more or less in linear series. Aperture oval ; margin thin, beaded or granular, a single acuminate submarginal spine below the aperture. Scattered avicularia over the polyzoary.

$H a b$. Britain (east coast?). In the mouths of rivers and estuaries, or in brackish water, spreading upon shells and stones, sometimes erect, free, foliaceous and contorted.

This species, which has probably been confounded with $M$. 
Lacroixii, to which, in the older state especially, it bears an extremely close resemblance, seems nevertheless to me to be quite distinct. It usually forms a delicate gauze-like coat upon shells and stones, and is then quite calcareous, though very delicate and thin ; but it also occurs in a more membranaceous condition and growing in an irregular foliaceous form of a greenish colour (dry). The only specimen of this sort that has come under my notice was kindly furnished by Dr. Landsborough ; it was found by Mr. Higham of Norwich in brackish water and in considerably sized masses. It can hardly, perhaps, be regarded as purely a marine form, and will be found I imagine more abundantly in rivers near the sea, or in shallow estuaries, than in the sea itself. It occurs in great plenty on shells and stones on the muddy bottom of the river Deben in Suffolk. I have also a specimen very like this species from St. Vincent, one of the Cape de Verde Islands.

\section{Membranipora magnilabris, n. s. Pl. LXV. fig. 4.}

Front of cell oval ; upper margin semicircular, much raised; moveable lip very large, occupying the entire semicircular upper third of the front of the cell, remainder of the front of cell depressed, membranous or semicalcareous, punctured.

Hab. Abrolhos Islet (Atlantic), Darwin. Algoa Bay, Bowerbank. On shell.

Very remarkable for the large size of the cells and the very great dimensions of the moveable lip; this part, as usual, is composed of a semicircular rim of horny matter; but besides this, the membrane stretching across the semicircle is further supported by two slender bars of horny substance, which extend from the side of the base to the centre of the bow, where they meet. This species might be regarded as the type of the cheilostomatous Polyzoa, and from its comparatively large size would probably be an interesting subject for examination in the living state.

\section{Membranipora galeata, n. s. Pl. LXV. fig. 5 .}

Front of cell oval; two pointed marginal spines on each side, towards the top. Ovicell galeate, widely open beneath, crowned with a large oblong avicularium.

$H a b$. East Falkland Islands, 4 to 10 fathoms, Darwin. On Laminaria.

Colour dark purple. 


\section{Lepralia.}

Polyzoarium adnate, crustaceous, spreading from a centre in a more or less circular form ; composed of contiguous or connected, calcareous, decumbent cells, the walls of which are complete in front.

Eschara (sp.), Moll, Seerinde; Pallas, Elench. Lepralia, Johnst. Brit. Zooph. ed. 2. p. 300; Gray, List Brit. Rad. p. 148 (part.).

Berenicea, Flem. Brit.An. 533, 1828 ; not Lamx. Exp. 80, 1821 ; nor Peron.

Escharina, sp., M.-Edw. Lamk. Hist. ed. 2. ii. 230 ; Gray, App. p. 148.

Escharoide, sp., M.-Edw. Lamk. Hist. ed. 2. ii. 259 ?

Cellepora, sp., Oken, Lehrb. Nat. 86, 1815; Audouin, Expl. Savigny, Egypt. (part.); Lamouroux (part.); Hagenow (part.). Flustra, id. ib.; Lamouroux (part.).

Discopora, Lamarck, Hist. (part.); Gray, App. p. 148 (part.); Lamouroux, Exp. Méth. (part.)

Cribrillina, Herentia, Escharella, Porella, Celleporella (all spec.), Gray, App. List Brit. Rad. pp. 147, 148, 149.

The very great number of species included under the above generic definition renders some subdivision of them indispensably requisite for the convenient determination of any particular form. In the absence of more precise knowledge respecting the living animals, we are not, I conceive, at present in a condition to propose a satisfactory natural arrangement, and the following disposition of the species therefore must only be regarded as artificial and contrived solely for the purpose of convenient reference.

\section{Synopsis of the Species of LEPRALIA.}

1. Armata. Species provided with either avicularia or vibracula.

A. Species having avicularia.

a. Median and single.

* Superior (above the mouth).

1. L. Brongniartii ......... 65

** Inferior (below the mouth).

2. L. Landsborovii........ 66

3. L. galeata .......... 66

4. L. reticulata ......... 66

5. L. marionensis ....... 67 
6. L. auriculata $\ldots \ldots \ldots \ldots \ldots \quad 67$

7. L. concinna ......... 67

8. L. verrucosa ......... 68

9. L. violacea.......... 69

ß. Avicularia double, or azygous and lateral; on each cell, or irregularly distributed throughout the polyzoary.

10. L. spinifera ......... 69

11. L. trispinosa $\ldots \ldots \ldots \ldots \ldots$. 70

12. L. coccinea........... 70

13. L. linearis .......... 71

14. L. alata ............ 71

15. L. monoceros.......... 72

16. L. bicristata ........ 72

17. L. margaritifera........ 72 (L. punctata (subinde)).

B. Species having vibracula.

18. L. ciliata .......... 73

19. L. Gattyæ ........... 73

20. I. Hyndmanni ........ 74

21. L. personata ......... 74

22. L. depressa $\ldots \ldots \ldots \ldots \ldots \quad 75$

23. L. Lyallii .......... 75

2. Inarmatæ. Species without either avicularia or vibracula.

a. With oral spines.

24. L. variolosa ......... 75

25. L. nitida............ 76

26. L. annulata $\ldots \ldots \ldots \ldots, 76$

27. L. bispinosa ......... 77

28. L. Peachii .......... 77

29. L. ventricosa.......... 78

30. L. melolontha $\ldots \ldots \ldots \ldots 78$

31. L. innominata $\ldots \ldots \ldots \ldots 79$

32. L. punctata ......... 79 (L. Malusii (subinde)).

$\beta$. With the mouth unarmed.

33. L. figularis.......... 80

34. L. pertusa ........... 80

35. L. pallasiana ......... 81

36. L. cucullata ........ 81 
Page

37. L. labiosa .......... 82

38. L. labrosa ........... 82

39. L. simplex ......... 82

40. L. areolata.......... 82

41. L. adpressa ......... 82

42. L. Malusii ........... 83

43. L. granifera ......... 83

44. L. hyalina .......... 84

45. L. discreta.......... 85

46. L. annularis ......... 85

1. Armatæ.

A. With avicularia.

a. Median and single.

* Superior.

1. Lepralia Brongniarti. Pl. LXXXI. figs. 1, 2, 3, 4, 5 .

Cells ovate, smooth, or transversely ringed, distinct, or separated by reticulated spaces; mouth circular; each cell with an avicularium at the summit above the mouth. Ovicell pyramidal, carinate in front, crowned by an avicularium.

Cellepora Brongniartii, Aud. Expl. i. 240, from Savig. Egypt. Polyp. t. 10. fig. 6.

Lepralia tenuis, Hassall, Ann.\& Mag. Nat. Hist. vii. 412; Johnst. Hist. Brit. Zooph. ed. 2. p. 303. t. 54. fig. 2.

Lepralia catenata, Peach, MSS.

Lepralia assimilis, Johnst. Hist.Brit.Zooph. ed.2. p. 304 ; Gray, List Brit. Rad. p. 117.

Lepralia Jacotini, Gray, List Brit. Rad. p. 117.

$\mathrm{Hab}$. Britain : common on shells, stones and fuci. Ayrshire, $\mathrm{Dr}$. Landsborough. Ireland, W. Thompson.

A very curious and interesting form, and one subject to great variety according to age and depth. It is remarkable for the number of avicularia with which the polyzoary is furnished. Besides the avicularium at the summit of each cell, or nearly so, or at that of the ovicell when it exists, the interspaces between the cells are studded with innumerable minute organs of the same 
kind, as will be apparent in fig. 1. Pl. LXXXI. There is often a prominent process beneath the mouth and projecting over it, as shown in fig. 5 , which represents the form I believe described by Dr. Hassall under the name of $L$. assimilis. Another peculiarity of this species is the extraordinary difference of dimensions exhibited in the cells of different specimens. The cells in Plate LXXXI. are all drawn to the same scale.

\section{** Avicularium inferior, or below the mouth.}

\section{Lepralia Landsborovir. Pl. LXXXVI. fig. 1 .}

Cells ovate, coalescent, separated by raised lines ; surface granular; mouth raised, circular, with a large and wide spout-like sinus below, within which is an avicularium?

Lepralia Landsborovii, Johnst. Hist. Brit. Zooph. ed. 2. p. 310. t. 54. fig. 9; Gray, List Brit. Rad.p. 119. Hab. Coast of Ayrshire, Landsborough. On Pecten opercularis.

The only specimen I have seen, or of which I can hear, is the one in the British Museum Collection. This gives the idea of an old or imperfect condition, and consequently the characters above assigned, and perhaps the species itself, may be regarded as only provisionally retained.

\section{Lepralia galeata, n. s. Pl. XCIV. figs. 1, 2.}

Cells ovato-ventricose, punctured all over; mouth orbicular, entire, unarmed; an avicularium immediately below the mouth; mandible oval. Ovicell globose, punctured.

Hab. Falkland Islands, T. del Fuego, Darwin. On fucus and shell.

4. Lepralia reticulata. Pl. XC. fig. 1. Pl. XCIII. figs. 1, 2. PI. CII. fig. 1.

Cells ovate-elongated; interspaces punctured; mouth raised, with a thin margin and a channelled sinus in the lower lip, two to three spines on the upper margin; a central avicularium immediately below the mouth; mandible acute. Ovicell globular, punctured, its opening bounded below by the meeting of its sides above the avicularium.

Lepralia reticulata, J. Macgillivray, Ann. \& Mag. Nat. Hist. ix. 467 ; Johnst. Hist. Brit. Zooph. ed. 2. p. 317. t. 55. fig. 10 ; Gray, List Brit. Rad. p. 120. 
?Flustra Montferrandii, Audouin, Expl. i. 240 ; Savigny, pl. 9. fig. 14.

Hab. Britain (south coast?): abundant on Eschara foliacea. Budleigh Salterton, Devon, Miss Cutler. Coast of Norfolk, Lieut. Thomas. Jersey, Mrs. Gatty. Egean Sea, E. Forbes. Copeland Islands, Bay of Belfast, deep water, W. Thompson. New Zealand, Dr. Lyall. (Pl. CII. fig. 1.)

The drawing in Plate XC. was made from a bad specimen and does not show the spines, which usually appear to exist only on the marginal cells.

5. Lepralia marionensis, n. s. Pl. XCVI. figs. $1,2$.

Cells ovate, distinct, punctured; mouth orbicular, a little raised above ; in front of the lower lip a large avicularium, with a spoonshaped mandible. Ovicell globose; surface granular; sides of the opening of the ovicell prolonged so as to enclose the avicularium.

Hab. Marion Islands, 80 fathoms, Dr. Hooker.

6. Lepralia auriculata. Pl. LXXXIX. figs. 4, 5, 6 .

Cells subovate or rhomboidal, usually quite immersed, and disposed in linear series, frequently punctured, especially round the margin; separated from each other by raised lines; mouth orbicular, with a shallow sinus below ; two to three oral spines ; a minute avicularium on an eminence immediately below the sinus of the lower lip; mandible crescentic. Ovicell subglobose, depressed, usually immersed, punctured.

Lepralia auriculata, Hassall, Ann.\& Mag. Nat. Hist. ix. 412; Johnst. Hist. Brit. Zooph. ed. 2. p. 310. t. 54. fig. 8; Gray, List Brit. Rad.p. 119.

Hab. Orkney, Lieut. Thomas, R.N. Belfast Bay, W. Thompson. Coast of Suffolk, G. B. Isle of Wight, id. Egean Sea, E. Forbes (var.). ?E. Falkland Islands, 4-10 fathoms, Darwin. Bray, Burnham, Norfolk, Hassall. Scilly, M`Andrew. On shell.

Attention to the position and form of the avicularia will at once suffice to distinguish $\boldsymbol{L}$. linearis, auriculata and trispinosa; species, as Dr. Johnston observes, very closely allied in general habit.

7. Lepralia concinna, n. s. Pl. XCIX.

Cells oval, rounded, or rhomboid in outline when deeply im- 
mersed; mouth rounded, immersed or level (never raised); a minute avicularium with semicircular or rounded mandible on or within the middle of the lower lip, which sometimes projects into a rostrum. Ovicell small, deeply immersed, inconspicuous, not punctated.

$H a b$. Copeland Islands, Belfast Bay, deep water, on shell and stone, $W$. Thompson. Belfast Bay, 20-25 fathoms, on shell, $i d$.

Forms an elegant close covering to stones and shells. The species appears to have been hitherto undistinguished, having apparently been confounded with L.immers a or trispinosa, Johnst., $L$. variolosa, \&c., but it is clearly distinct and readily characterized by the mouth, which is never raised, and usually, in the older portions of the patch, deeply immersed; its form is wide above and contracted below, but without the sinus of $L$. reticulata and trispinosa; nor is it furnished with any spines; and the central avicularium on the lower lip is within, or at all events immediately on, or forming part of the margin of the mouth, and not a little below it as in $L$. reticulata, in which species, moreover the mandible is acute. From $L$. auriculata also it differs in the absence of oral spines.

\section{Lepralia verrucosa. Pl. LXXXVII. figs. 3,4. Pl. XCIT. fig. 6 .}

Cells immersed at the base, ventricose, front rising into a strong pyramidal rostrum or umbo, from which ridges radiate towards the sides and bottom; surface usually verrucose; mouth orbicular, upper margin deeply immersed, sometimes rising on each side into a blunt tooth-like process, and sinuous in front, sometimes quite plain; an avicularium with semicircular mandibles on the upper side of the rostrum or umbo. Ovicells - ?

? Cellepora verrucosa, Esper, Cellep. t. 2. figs. 1, 2; not Discopora verrucosa, Lamk. Hist. ii. 164, ed. 2. ii. 248.

? Lepralia Johnstoni, Bean, MSS.

Lepralia verrucosa, $W$. Thompson, Ann. Nat. Hist. xiii. 441 ; Johnst. Hist. Brit. Zooph. ed. 2. p. 316. t. 56. fig. 3.

Lepralia reticulata, Couch, Corn. Faun. iii. 117. pl. 22. fig. 9. Discopora verrucosa, Gray, List Brit. Rad. p. 126.

Hab. Scarborough, Bean. Scotland (Ayrshire?), Dr. Landsborough.

The avicularium on the upper side of the projecting rostrum or umbo is to a great degree concealed by that process in front, but will be observed if the specimen be turned in such a direction that a view of the upper side of the projection is obtained. 
9. Lepralia violacea. Pl. LXXXVII. figs. 1, 2. Pl. CX. fig. 1 (var. cruenta).

Cells ovate or pyriform, surface uneven; mouth suborbicular; an avicularium immediately below the middle of the lower lip, with an acute mandible pointing upwards, and in the centre of the front of the cell a perforation? or depression.

Lepralia violacea, Johnst. Hist. Brit. Zooph. ed. 2. p. 325. t. 57. fig. 9.

Escharella violacea, Gray, List Brit. Rad.p. 125. $H a b$. Isle of Man, E. Forbes. Cornwall, C. W. Peach. Bay of

Gibraltar, M`Andrew, Dr. Landsborough. Orkney?, Dr. Greville.

Colour blue or purple, sometimes very deep : like many other Lepralia it is liable to be much overgrown or thickened, but in any state it may be recognized by the depressions left by, or the vestiges of the suboral avicularium and the central hollow. Specimens in this condition I have received from Dr. Greville, collected in the Orkneys, remarkable for the great thickening of the cell-wall and their deep purple or rather crimson colour.

B. Avicularia either double, or if single, on one side of the cell : on every cell, or irregularly distributed on the polyzoary.

10. LePralia SPINIFera. Pl. LXXVI. figs. 2,3. PI. LXXX. figs. 4, 5, 6,7. Pl. LXXXI. figs. 6, 7. Pl. XCI. figs. $1,2$.

Cells ovate, ventricose, surface punctate or granular; usually a central umbo in front, upon which is occasionally articulated a long spine ; often a raised avicularium on each side at the top of the cell close to the mouth; mouth with a narrow sinus in the lower lip, and three to eight marginal spines (often wanting). Ovicell globose, with grooves radiating from the centre.

? Eschara spongites, Moll, Seerinde, p. 37. pl. 1. fig. 3.

Lepralia ciliata, Hassall, Ann. \& Mag. Nat. Hist. vi. 171, \& vii. 367. pl. 9. fig. 2.

Lepralia spinifera, Johnst. Hist. Brit.Zooph. i. 324.pl. 57. fig. 6 ; Gray, List Brit. Rad. p. 122.

Lepralia unicornis, Johnst. (op. cit. p. 320. pl. 57. fig. 1.)

Berenicea coccinea, Johnst. Trans. Newc. Soc. ii. 267. pl. 12. fig. 5.

Lepralia coccinea, Johnst. Brit. Zooph. 278. pl. 34. figs. 1-3; Hassall, Ann. \& Mag. Nat. Hist. vii. 367; Couch, Corn. Faun. iii. 115 ; W. Thompson, Ann. Nat. Hist. v. 253. 
Escharina unicornis, Gray, l. c. p. 124.

Hab. Isle of Wight, G. B. Coast of Devon, Miss Cutler. Bay of Gibraltar, Landsborough, $M^{\bullet}$ Andrew. ? Port Natal, $W$.

Stanger. On fuci and shells.

From the comparison of numerous specimens in all forms and stages, I feel satisfied of the identity of L. spinifera (Hassall) and L. unicornis (Johnston). The peculiar sculpture of the ovicell, conjoined with the sinus in the lower lip and the lateral avicularia, are sufficiently characteristic, without the often-wanting central umbo and articulated spine.

\section{Lepralia trispinosa. Pl. LXXXV. figs. 1, 2. Pl. XCVIII. Pl. CII. fig. 2.}

Cells ovate, usually punctured round the edge ; mouth raised, with a thin border, lower lip forming a sinuous spout, two or three spines above; occasionally an avicularium on the side of the cell; mandible acute, pointing upwards and outwards.

Discopora trispinosa, Johnst. Edinb. Phil. Journ. xiii. 322.

Berenicea trispinosa, Johnst. Trans. Newc. Soc. ii. 268.

Lepralia trispinosa, Johnst. Brit. Zooph. p. 280. pl. 34. fig. 5;

Couch, Corn. Faun. iii. 118 ; J. Macgillivray, Ann. \& Mag. Nat. Hist. ix. 467 ; Johnst. Hist. B. Z. ed. 2. p. 324. t. 57. fig. 7; Gray, List Brit. Rad. p. 122.

Lepralia variolosa, var. a, Johnst. Brit. Zooph. ii. 317. pl. 55. fig. 8.

Var. a. With a rostrum below the mouth.

Hab. Coast of England, Scotland and Ireland, common. Cape Horn, 40 fathoms, Darwin.

Notwithstanding the great diversity in aspect of different specimens, the characters above given will in most cases be recognized in one part or another of the polyzoary, and will suffice to distinguish the species from those with which it has apparently been confounded, viz. L. variolosa, concinna, and $L$. Peachii (L. immersa, Johnst.).

\section{Lepralia coccinea. Pl. LXXXVIII.}

Cells oval or shortly cylindrical; mouth with a central mucro on the lower lip and two lateral teeth; several (six) spines above; an avicularium on each side close to the mouth. Ovicell globular, surface granular.

Cellepora coccinea, Abildgaard, Müll. Zool. Dan. iv. 30. t. 146. figs. 1, 2; Lamk. Anim. s. Vert. ed. 2. ii. 259. 
Berenicea coccinea, Flem. Brit. Anim. p. 533; Johnst. Edin. Phil. Journ. xiii. 222.

Lepralia coccinea, Johnst. Hist. Brit.Zooph. ed. 2. p. 322. t. 57. figs. $2,3$.

Lepralia tridentata, Couch, Corn. Faun. p. 115. pl. 22. fig. 5.

Var. $\beta$. With a triangular slit or loop on each side of the aperture. Lepralia appensa, Hassall, Ann. \& Mag. Nat. Hist. vii. 367. pl. 9. fig. 3.

Lepralia ansata, Johnst. Hist.Brit.Zooph.ed.2.p.307.t.54.fig.12. Lepralia Ballii, Johnst. Hist. Brit.Zooph. ed.2.p. 321.t.56. fig. 5. Escharina coccinea, Ballii, ansata, Gray, List Brit. Rad. p. 124. $H a b$. Portaferry, Ireland; Belfast Bay ; Isle of Wight, W.Thompson. Start Point, I. S. Bowerbank. Sidmouth, Mrs. Gatty. Coast of Ayrshire, Landsborough. Isle of Man, E. Forbes. Cornwall, C. Peach. St. Andrews, Prof. Reid. Falmouth, Cocks. Off the Tees, Lieut. Thomas, R.N. On stones and shells, \&c.

Comparison of the various figures will suffice to show the identity of all these forms. This species is one of those which undergoes a remarkable change in deep water, becoming very strong and thick, and the spines are often worn off.

\section{Lepralia linearis. Pl. LXXXIX. figs. 1, 2, 3.}

Cells completely immersed, much depressed, rhomboidal or subovate, disposed in linear series, and separated from each other by a raised line; mouth orbicular, with a sinus below; two to three oral spines; a small avicularium on a rounded mamillary eminence on either side of the cell in front, sometimes single and central ; mandible acute, triangular. Ovicell globose, prominent, punctured.

Lepralia linearis, Hassall, Ann. \& Mag. Nat. Hist. vii. 368. pl. 9. fig. 8 ; Johnst. Hist. Brit.Zooph. ed.2.p.308.t.54.fig.11. Herentia linearis, Gray, List Brit. Rad. p. 123.

Hab. Start Point, J. S. Bowerbank. Coast of Suffolk, G. B. Orkney, Barlee. Beaufort Dyke, 110-147 fathoms, Captain Beechey, R.N. Roundstone, W. Thompson. Carrickfergus, $i d$. Strangford Loch, id. Belfast Bay, 20 to 25 fathoms, $i d$. Mediterranean, $M^{*}$ Andrew. East of Kingstown Harbour, and Giant's Causeway, Hassall. On shell.

\section{Lepralia alata, n. s. Pl. LXXIX. fig. 3.}

Cells immersed; outline oval or subrotund ; front with grooves radiating to a central eminence or umbo; mouth suborbicular, with two to three spines above; a small avicularium on each side of the body about or below the middle, directed horizontally outwards.

Hab. Cape Horn, 40 fathoms, on pebble, Darwin. 
Its nearest congener is Lepralia verrucosa; it is, however, much smaller, and distinguished by the lateral, alar avicularia. In the older state the appearance of the polyzoary is very confused, and the peculiar characters are only to be sought at the growing edge, and in the younger or more recent cells.

\section{Lepralia monoceros, n.s. Pl. XCIII. figs. 5, 6.}

Cells immersed, outline more or less oval, broad above, pointed below; surface punctured; mouth narrow, transverse, a strong projecting rostrum on the lower margin; a very strong and long articulated spine on one side only of the mouth. Ovicell pyramidal, hollowed inferiorly in front, and often crowned with a small avicularium on the summit; numerous scattered avicularia of larger and smaller size on or between? the cells, throughout the polyzoary.

Hab. Straits of Magellan, 10 to 20 fathoms ; Tierra del Fuego;

Patagonia, $48^{\circ} 56^{\prime}$ S. L., 19 fathoms ; Falkland Islands, 4 to

10 fathoms; Cape Horn, 40 fathoms, Darwin. On stone and fuci.

A very peculiar and remarkable form, readily distinguishable by the enormous azygos spine on one side of the mouth, which appears to be articulated to a short basal joint by a constricted portion composed of cartilaginous or horny substance.

\section{Lepralia bicristata. Pl. XCIV. figs. $3,4,5$.}

Cells ovate, ventricose, punctured round the margin, with a central umbo perforated above; occasionally a small avicularium with a pointed mandible on one side of the cell near the top; mouth straight below, with four to six oral spines. Ovicell globose, with two raised keels running across it from side to side. Hab. Cape Horn, 40 fathoms, Darwin.

\section{Lepralia margaritifera. Pl. CI. figs. 5,6 .}

Cells deeply immersed, outline marked by punctures; front of cell raised into an elevated umbo; mouth very large, nearly round, with a thickened margin; numerous larger and smaller oval avicularia dispersed all over the polyzoarium, usually one on the side of the mouth of each cell. Ovicell immersed, umbonate in front.

F. margaritifera, Quoy \& Gaimard, Voy. de l'Uranie, pl. 92. figs. $7,8$.

Hab. Tierra del Fuego, on shell, Darwin. 
B. Species having vibracula.

18. Lepralia ciliata. Pl. LXXiV. figs. 1, 2. Pl. LXXViI. figs. $3,4,5$.

Cells ovate or subglobose, surface granular, an elongated acuminate vibraculum on one side of the body; a semilunar pore frequently on an eminence in the middle of the front of the cell, above the centre; mouth with numerous (five to seven) spines; lower lip straight, entire. Ovicell globose, surface granular.

Eschara ciliata, var. $\beta$, Pall. Elench. 38.

Eschara vulgaris, var. $\beta$, Moll, Seerinde, p. 62. pl. 3. fig. 11.

Cellepora ciliata, Linn. Syst. 1286; Fabr. Faun. Gronl. 434. no. 441.

Berenicea utriculata, Flem. Brit. Anim. 533.

Lepralia ciliata, Johnst. Brit. Zooph. 279. pl. 34. fig. 6 ; Couch, Corn. Faun. iii. 118. pl. 22. fig. $10 ; W$. Thompson, Ann. Nat. Hist. v. 253; J. Macgillivray, Ann. \& Mag. Nat. Hist. ix. 467 ; Johnst. Hist. Brit. Zooph. ed. 2. p. 323. pl. 57. figs. 4, 5 ; Gray, List Brit. Rad. p. 121.

Lepralia insignis, Hassall, Ann. \& Mag. Nat. Hist. vii. 368. t. 9. fig. 5 ; Couch, Corn. Faun.t. 22. fig. 11; J.Macgillivray, Ann. \& Mag. Nat. Hist. ix. 467.

Lepralia ciliata, var. $\beta$, Johnst. Brit. Zooph. ed. 2. p. 323.

Flustra Genisii, Aud. Expl. p. 239, from Savig. Egypt. Rept. t. 9. fig. 5 .

Escharina vulgaris, part., M.-Edw. Lamk. Hist. ed. 2. 231 ?; Gray, List Brit. Rad. p. 123.

Hab. Britain (South Coast?); Mediterranean? Savigny. Belfast Bay, W. T. America, Pallas, non vidi. Beaufort Dyke, 110 to 145 fathoms, Capt. Beechey.

The spines are frequently wanting in old and worn, or perhaps deep water specimens. On careful inspection, however, the stumps of them may usually be observed, but the existence of the opening for the vibraculum on the side of the body, and the crescentic opening in the middle, will, together, always suffice, in every state, to distinguish the present from any other British form.

19. Lepralia Gattya. Pl. LXXXIII. fig. 6.

Cells ovate, pointed inferiorly, raised in front or umbonate, punctate, with shallow radiating grooves; mouth rounded above, lower lip straight; five oral spines, the base of which is black; a slender vibraculum on each side at the top of the cell; a semilunar pore in front above the centre. Ovicells globose, punctured. 
? F. coronata, Aud. i. 239. pl. 9. f. 6.

Lepralia Gattyæ, Landsborough, Hist. Brit. Zooph.pl. 18 fig. 71. Hab. Sidmouth, Mrs. Gatty. On Phyllophora rubens, Jersey, J. Alder.

This very pretty species, to which my attention was first drawn by Mrs. Gatty, appears hitherto to have escaped recognition, and as the British Fauna is indebted to that acute observer for this addition, her name has been assigned to it. In some respects it hears a very close resemblance to the figures of $F$. coronata, Audouin, Savign. Egypt. pl. 9. f. 6, but I am inclined to think that it is distinct from that species, and in fact it seems to me that $F$. coronata and $F$. umbracula of the same work are identical; if so, the ovicells of $F$. umbracula are so peculiar as at once to. remove any suspicion of the former species being one and the same with $L$. Gattya; but besides this, $F$. coronata appears to want the central umbo which exists in all specimens of $L$. - Gattya; and the cells, if correctly drawn, are much wider below than those of the latter species, which terminate inferiorly in an acute point. The resemblance, however, between the two is very close, and should $F$. coronata and $F$. umbracula really not be identical, a very strong suspicion would arise of the identity of the former with $L$. Gattyæ.

20. Lepralia Hyndmanni. Pl. LXXXVII. figs. 5, 6, 7, 8.

Cells subglobose, raised in front; mouth orbicular, with a sinus in the middle of the lower lip; a long slender setose vibraculum on one side of the body. Ovicell small, arcuate.

Lepralia Hyndmanni, Johnst. Hist. Brit. Zooph. ed. 2. p. 306. t. 54 . fig. 6 .

Herentia Hyndmanni, Gray, List Brit. Rad. p. 122.

Hab. Sana Island, Hyndman. Belfast Bay, W. Thompson.

Beaufort Dyke, off the west coast of Scotland, dredged by

Capt. Beechey in 110-145 fathoms.

21. Lepralia personata, n. s. Pl. XC. figs. 2, 3, 4.

Cells oval, surface granular; mouth with a straight lower lip and five to seven spines above; a long vibracular process on one side of the body, and a central semilunar pore. Ovicell prominent, subglobose, with the lower lip very much produced and projecting.

Hab. East Falkland Islands, 4-10 fathoms, Darwin. On stones and fucus.

Except in the much larger size of the cells and the greater comparative length of the vibraculum, this form closely ap- 
proaches Lep. ciliata; the difference in the form of the ovicell, however, - a striking and peculiar feature in the present species, -appears amply sufficient to justify their separation. The form of the ovicell in F. (L.) umbracula (Aud.Expl.i. p. 239 ; Savign. Egypt. pl. 9. fig. 3) is very similar apparently to that of $L$. personata, as is also in some degree that of the ovicells of $L$. galeata mihi, Pl. XCIV. figs. 1,2 ) and of $L$. reticulata (Pl. XCIII. figs. 1,2$)$.

22. Lepralia depressa, n. s. Pl. XCI. figs. 3, 4.

Cells quite immersed, depressed, the upper margin only being slightly raised; outline suborbicular or suboval; mouth contracted in the middle, the lower half being filled in by a horny membrane, lip slightly thickened; a semicircular penthouse-like projection a short distance above the mouth; a vibraculum on the side of the cell nearly on a level with the mouth.

$H a b$. Egean Sea, on fucus, loosely attached, $E$. Forbes.

23. Lepralia Lyallit, n. s. Pl. CIII. fig. 6.

Cells oval, walls thin, verrucose or rugose; mouth raised, margin thickened, with a spout-like sinus in front, and five to six spines on the sides and above; a small vibraculum on many of the cells, on one side near the top.

Hab. New Zealand, on fucus, Dr. Lyall, R.N.

\section{Inarmatæ.}

Without either avicularia or vibracula.

a. With oral spines.

24. Lepralia variolosa. Pl. LXXIV. figs. $3,4,5$. Pl. LXXV.

Cells oval, immersed or subimmersed, usually disposed in linear series; punctured or areolated round the margin, granular (sometimes punctured) in front ; mouth rounded or subquadrangular, with two to four close-set spines quite at the summit; lower lip with a projecting mucro and an internal bifid denticle. Ovicells deeply immersed, also areolated round the margin.

Lepralia variolosa, Johnst. Brit. Zooph. 278. pl. 34. fig. 4; Hassall, Ann. \& Mag. Nat. Hist. vii. 367 ; Couch, Zooph. Cornw. 50 ; Corn. Faun. iii. 116. pl. 22. fig. 6; W. Thompson, Ann. Nat. Hist. v. 253; Johnst. Hist. Brit. Zooph. ed. 2. p. 317. t. 55. figs. \&, 9 . 
Var. $\beta$. Lip with a denticle on the proximal margin, Johnst. Brit. Zooph. ed. 2. 317. t. 55. fig. 9.

Escharella variolosa, Gray, List Brit. Rad.p. 125.

Lepralia ovalis, Hassall, Ann. Nat. Hist. ix. 413 ; Johnst. Brit. Zooph. ed. 2. p. 307. pl. 56. fig. 1.

Mr. Peach appears to have noticed two marginal spines in this species, although the absence of spines enters into the characters given to it by the learned author of British Zoophytes; which is the more to be wondered at, since he quotes Mr. Couch's figure (pl. 22. fig. 6), in which three spines are represented. But as the next figure of what Mr. Couch terms $L$. vinca does not exhibit the smallest difference from that of his $L$. variolosa, I find it difficult to determine to what either of his forms really belongs. This synonym, therefore, must be admitted with great dubiety. This is one of the species which, when overgrown, is difficult of immediate recognition.

\section{Lepralia nitida. Pl. LXXVI. fig. 1 .}

Cells ovate, raised in front; wall composed of four to nine ribs on each side, the spaces between which are filled up by a diaphanous membrane; mouth with four to six oral spines. Ovicell subglobose, surface granular. (Occasionally an avicularium on a small eminence at the lower point of the cell, or irregularly scattered in the interstices between the cells.)

Cellepora nitida, Fabr. Faun. Gronl. 435. no. 443.

Cellepora (Escharoide) nitida, M.-Edw. Lamk. Anim. s. Vert. ed. 2 . ii. 259.

Berenicea nitida, Flem. Brit. Anim. 533.

Lepralia nitida, Johnst. Brit. Zooph. 277.pl.34. fig. 7 ; Hassall, Ann. \& Mag. Nat. Hist. vii. 367 ; W. Thompson, Ann. Nat. Hist. v. 253; Couch, Corn. Faun. ii. 114. pl.22. fig. 3; Gray, List Brit. Rad. p. 120.

Hab. Coast of Devon, Miss Cutler. Start Point, J. S. Bowerbank. Coast of Ayrshire, Landsborough. Isle of Man, $E$. Forbes. Scarborough, Bean. Berwick Bay, Johnston. Coast of Cornwall, Peach. Strangford Loch, W. Thompson. On shell and stone.

\section{Lepralia annulata. Pl. LXXVII. fig. 1.}

Cells ovate, distinct; front slightly keeled, with five to seven shallow grooves on each side, each groove with a series of perforations; mouth suborbicular, margin thickened in the fertile cells, projecting into a mucro above and below ; three distant 
oral spines (wholly wanting in the fertile cell). Ovicell very small, inconspicuous, deeply immersed.

Cellepora annulata, Fabr. Faun. Gronl. 436. no. 444; Turt. Gmel. iv, 641.

Lepralia annulata, Johnst. Hist. Brit. Zooph. ed. 2. p. 313. t. 55. figs. 2, 3; Gray, List Brit. Rad. p. 122.

Cellepora (Escharoide) bimucronata, Lamx. Corall. 41 ; Lamk. Anim. s. Vert. ed. 2. ii. 260.

Eschara bimucronata, Moll, Eschara, 65. t. 3. fig. 18. $H a b$. Coast of Ayrshire, Landsborough. Shetland, Barlee.

The distinctness and usually larger size of the cells in this species, their having only three to four distant (the two lateral of which are much stronger than the others) oral spines, which are almost always, if not always, totally obsolete in the fertile cells, the peculiar arrangement of the pores, and, above all, the invariable absence of avicularia on each side of the mouth, will suffice to distinguish it from the deep-sea, thickened, or overgrown form of L. punctata, figured in Pl. XC. figs. 5, 6, to the mouth of which that of the fertile cells of $L$. annulata bears a very close resemblance.

\section{Lepralia bispinosa. Pl. LXXX. figs. 1, 2, 3, 4 .}

Cells ovate, elongated, sometimes shorter and ventricose; mouth rotund or subquadrangular, with two long spines on the upper margin, and a strongly projecting mucro in front of the lower lip.

Lepralia bispinosa, Johnst. Hist. Brit. Zooph. ed. 2. p.326. t. 57. fig. 10.

Discopora bispinosa, Gray, List Brit. Rad.p. 126.

Hab. Coast of Devon, Miss Cutler. Berwick Bay, Johnston. On shell.

\section{Lepralia Peachil. Pl. LXXXII. fig. 4. Pl. XCVII.}

Cells globose, subimmersed, often punctured round the margin; surface granular or smooth; mouth suborbicular, with a thickened, slightly raised border, and six spines; a simple or bifid denticle on the lower lip, and usually a rostrum in front of the mouth. Ovicells immersed, with two spines in front of it on each side.

Lepralia Peachii, Johnst. Hist. Brit. Zooph. ed. 2. p. 315. t. 54. figs. 5, 6; Gray, List Brit. Rad. p. 118.

Lepralia immersa, Johnst. Hist. Brit.Zooph. ed. 2. p. 325. pl. 57. fig. 8.

Escharella immersa, Gray, List Brit. Rad.p. 125. 
Berenicea immersa, Flem. Brit. Anim. 533.

? Berenicea flava, Johnst. Trans. Newc. Soc. ii. 268.

- Hab. Start Point, J. S. Bowerbank. Orkney, Lieut. Thomas.

Coast of Devon, Miss Cutler. Belfast Bay, 20 to 35 fathoms,

$W$. Thompson. Compton Bay, Isle of Wight, id. Dalkey,

id. Beaufort Dyke, 110 to 147 fathoms, Captain Beechey.

Notwithstanding the apparently marked distinction between the typical forms of $L$. variolosa, $L$. ventricosa, and $L$. Peachii, some difficulty will be found in distinguishing them under certain conditions of age and overgrowth, or when much worn. In $L$. variolosa the ovicell is always deeply immersed, and has in front of it a single spine, or the stump of a single spine only, on each side; the normal number of oral spines in this species appearing to be two to three (in the former case it constitutes, as I imagine, L. ovalis, Hassall). In $L$. Peachii the ovicell is also immersed, but not so deeply, and always has two, or the remains of two, oral spines on each side in front of it, the normal number of these spines being, in this species, six ; whilst in L. ventricosa, besides the more erect position, generally, of the upper part of the cell, the greater elevation of the mouth, \&c., the ovicell is, comparatively speaking, free or much raised, shows, I believe, no spine in front of it, or one only, and the number of oral spines is invariably, or nearly so, four. With respect to the association of $L$. Peachii and immersa, Johnst., there can, I think, upon inspection of the figures in Brit. Zooph., be no doubt of its propriety.

29. Lepralia ventricosa. Pl. LXXXII. figs. 5, 6. Pl. LXXXIII. fig. 5. Pl. XCI. figs. 5, 6.

Cells distinct above, or raised, immersed at the base, ventricose, ovate or subglobose; mouth orbicular, with a thickened raised margin ; a bifid denticle on the lower lip, and four (rarely more) marginal spines; surface granular or irregularly striated; usually a pointed or broad mucro in front of the mouth. Ovicells globular, prominent.

Lepralia ventricosa, Hassall, Ann. \& Mag. Nat. Hist. vii. 412; Johnst. Hist. Brit. Zooph. ed. 2. p. 305. t. 54. fig. 5; Gray, List Brit. Rad. p. 118.

Hab. Start Point, J. S. Bowerbank. Belfast Bay, W. Thompson.

Strangford Loch, id. Beaufort Dyke, 110 to 147 fathoms,

Captain Beechey.

30. Lepralia melolontha. Pl. LXXXV. fig. 3.

Cells distant, in linear series, obovate; a pointed conical 
ascending process at the lower end; wall composed of six to eight contiguous ribs on each side; mouth suborbicular, with a projecting tubular process on each side, and two slender oral spines above. Ovicell —?

I.epralia melolontha, Landsborough's Pop. Brit. Zooph. p. 18. pl. . fig. 70 .

Hab. Estuary of the Thames, Lieut. Thomas, on shell. East Coast! Mrs. Gatty; Busk.

A very peculiar species, though in the costate structure of the cell approaching $L$. nitida, and to which it seems, perhaps, too closely allied. It grows in linear series, which branch out in an arborescent manner, closely adhering to the surface of dead shells. These branches, in process of growth, become more and more crowded, and finally coalesce into a continuous expansion. I tirst noticed this form in the year 1852, on some shells dredged at the mouth of the Thames by Lieut. Thomas, R.N., and afterwards found it on the coast of Suffolk, near the mouth of the Orwell ; and about the same time it was found and its peculiarities observed by Mrs. Gatty.

31. Lepralia innominata. Pl. LXXXVI. figs. 2, 3.

Cells subglobose or ovate, rising in front into an umbo or short keel ; furrowed, the grooves radiating from the central line; mouth suborbicular, with the lower lip straight ; four to six marginal spines; a perforation a little below the mouth and above the umbo.

Lepralia innominata, Couch, Corn. Faun. iii. 114. pl. 22. fig. 4 ; Johnst. Hist. Brit. Zooph. ed. 2. p. 320. t. 55. fig. 12; Gray, List Brit. Rad. p. 121.

Lepralia pectiuata, Peach, MS.

Hab. Start Point, J. S. Bowerbank. Coast of Cornwall, Peach. Off Sana Island, G. C. Hyndman. On shell.

32. Lepralia punctata. Pl. XC, figs. 5, 6. Pl. XCII. fig. 4. Pl. XCVI. fig. 3.

Cells subcylindrical, irregular, frequently wholly immersed, foraminiferous, the punctures obscurely rowed transversely; mouth oblong, transverse, occasionally very narrow, lower lip projecting, mucronate; four to six spines above, often wanting. Ovicell pyramidal, obscurely keeled in front, and sometimes crowned with a small avicularium at the apex; occasionally a small avicularium on one or both sides at the upper part of the body close to the mouth.

Lepralia arenacea, Bean, MS. 
Lepralia punctata!, Hassall, Ann. \& Mag. Nat. Hist. vii. 368 . pl. 9. fig. 7 ; Johnst. Hist. Brit. Zooph. ed. 2. p. 312. t. 55 . fig. 1. 478.

Cribrilina punctata, Gray, List Brit. Rad. p. 117.

$H a b$. Britain, not uncommon. Bangor, Co. Down, $W$. Thompson. Macgilligan, $i d$. Ayrshire, Dr. Landsborough. Start Point, Devon, J. S. Bowerbank.

Notwithstanding the high authority of Mr. Bean and of $\mathrm{Mr}$. Peach, there is no doubt that Dr. Hassall is quite right in assigning spines to the margin of the mouth. It is a very protean species, and in the old and deep-water condition requires some discrimination to distinguish it.

\section{B. With an unarmed mouth.}

33. Lepralia figularis. Pl. LXXIII. figs. 1, 2, 3.

Cells deeply immersed, confluent; central and upper portion of the front raised into an oval area, marked with five to six rows of punctures in shallow grooves radiating from the centre, and around the border of the raised area a series of eminences, either perforate at the apex or prolonged into short tubular processes ; mouth orbicular, unarmed. Ovicell globose, lofty, with a central keel and a pyriform or lunate fossa on each side.

Lepralia figularis, Johnst. Hist. Brit. Zooph. ed. 2. p. 314. t. 56. fig. 2; Gray, List. Brit. Rad, p. 119.

Hab. Cornwall, Peach. Jersey, J. Alder.

34. Lepralia pertusa. Pl. LXXVIII. Pl. LXXiX. figs. 1, 2.

Cells ovate-ventricose, distinct or rhomboid, depressed, immersed, separated by a raised line, punctured; mouth orbicular, even, or slightly sinuated below; margin thickened, unarmed, usually an irregular tubercle below the mouth. Ovicells globose, punctured.

Cellepora pertusa, Esper, Pflanz. Cellep. p. 149. t. 10. fig. 2.

Lepralia pertusa, Johnst. Hist. Brit. Zooph. ed. 2. p. 311. t. 54. fig. 10; Gray, List Brit. Rad. p. 119.

Escharina pertusa, M.-Edwards, Lamk. Anim. s. Vert. ed. 2. ii. 232.

Cellepora perlacea, W. Thompson, Ann \& Mag. Nat. Hist. x. 20.

Escharina perlacea, M.-Edwards, Lamk. Anim. s. Vert. ed. 2. ii. 234.

Hab. Orkney, Lieut. Thomas, R.N. Dartmouth, E. Forbes. Isle of Man, $i d$. Cornwall, Peach. Off Sana Island, G. C. Hyndman. On shells and stone. ? Australia, Macgillivray. 
The figures given in this Catalogue will convey some idea of the multiplicity of forms assumed by this protean species.

\section{Lepralia pallasiana. Pl. LXXXIII. figs. $1,2$.}

Cells ovato-ventricose, surface verrucose, reticulate; mouth contracted below the middle, raised, with a plain thickened margin; lower lip straight.

Eschara pallasiana, Moll, Seerinde, p. 64. pl. 3. fig. 13.

Flustra hibernica, Hassall, Ann. \& Mag. Nat. Hist.vi. 172. pl. 7 . fig. $1, \&$ vii. 370. (The figure quoted "represents a posterior view of the cells, the wall of each cell posteriorly being absent.")

Lepralia pedilostoma, Hassall, Ann. \& Mag. Nat. Hist. vii. 368. pl. 9. fig. 4.

Lepralia pediostoma, Johnst. Hist. Brit. Zooph. ed. 2. p. 315. t. 54. fig. 7; Couch, Corn. Faun. p. 113. pl. 22. fig. 14.

Cellepora pallasiana, Lamx. Polyp. Flex. p. 95. no. 190; Encyclop. p. 184. no. 22.

Hab. Jersey, Alder. Off Copeland Islands, Bay of Belfast, deep water, $W$. Thompson. Dublin Bay; Plymouth Sound, Hassall. Cornish coast, very plentiful, Peach. Coast of Ayrshire, Landsborough. Berwick Bay (very rare), G. Johnston. Coast of Devon, Miss Cutler.

36. Lepralia cucullata, n. s.? Pl. XCVI. figs. 4, 5 .

Cells ovate, black, surface granular; mouth looking forwards, orbicular, upper margin usually arching over like a hood. Ovicell $\longrightarrow$ ?

? Cellepora Mangnevillana, Audouin, Expl. i. 239 ; Savigny, Egypt. pl. 8. fig. 6 (non Lamouroux). $H a b$. Egean Sea, $E$. Forbes.

In the absence of ovicells in the specimens in my possession, it is impossible to determine whether or no the present is identical with the species figured by Savigny, to which however, in other respects, it bears a very close resemblance. This form, although named by Audouin Mangnevillana, is clearly not the one intended by Lamouroux under that appellation (vid. Polyp. Flex. p. 890. pl. 1. fig. 3.a. B). A species of the same black colour, and in all respects resembling the present except in the less obliquity of the mouth and the absence of the raised upper border, occurs in Gibraltar Bay (Dr. Landsborough). The latter form is very like $L$. reticulata. 
37. Lepralia labiosa, n. s. Pl. LXXXV. figs. 4, 5 .

Cells pyriform or elongated and narrow at bottom, wide above, surface verrucose ; mouth horizontal, rounded, with a deep sinus in front and an enormously thick, rounded projecting lip. Ovicell small, globose or subpyramidal; surface granular or verrucose.

Hab. Falkland Islands, Darwin. Completely incrusting a fucus, but readily detached.

Cells rounded and apparently unattached behind; they are of large size and very strongly constricted, of a deep brown colour.

38. Lepralia labrosa, n. s. Pl. XCII. figs. 1, 2, 3.

Cells ovate, punctured, disposed in linear series, branching from a common centre ; mouth orbicular, with a much-raised, thickened and expanded lip, which is usually deficient above. Ovicell globose, smooth, recumbent.

Hab. Off Copeland Islands, Belfast Bay, deep water, W. Thompson. On the inside of a dead shell.

Perhaps a variety of $L$. ventricosa.

39. Lepralia simplex. P1. LXXXIV. figs. 1, 2 .

Cells ovate, ventricose, erect superiorly and free; walls smooth, dense; mouth raised, suborbicular, or slightly sinuated below, with a thickened margin, usually an umbo on the front of the cell.

Lepralia simplex, Johnst. Hist. Brit. Zooph. ed. 2. p. 305. t. 54. fig. 4; Gray, List Brit. Rad. p. 118.

Hab. Belfast Bay, $2 C-35$ fathoms, $W$. Thompson. Off Sana Island, G. C. Hyndman.

40. Lepralia areolata, n. s. Pl. LXXXIII. figs. 3, 4.

Cells subovate or diamond-shaped, depressed, quite immersed, quincuncial, outlines marked by raised lines; surface granular; mouth suborbicular, with a sinus below and a raised and thickened margin.

Hab. Straits of Magellan, 10-20 fathoms, Darwin. On stone.

41. Lepralia adpressa, n. s. Pl. CII. figs. 3, 4.

Cells quincuncial, oval, depressed, surface marked with grooves radiating from the lower border of the mouth; surface smooth; mouth rounded above, contracted below the middle, and with a straight lip below; margin slightly raised and thickener.

Hab. Chiloe, 96 fathoms, on shell, Darwin. 
Forms a very closely adpressed crust on the outside of a small univalve shell.

\section{Lepralia Malusii. Pl. Cill. figs. 1, 2, 3, 4.}

Cells ovate, frequently truncate at each end; front, especially round the margin, punctured with numerous stelliform pores; a central lunate pore; mouth rounded above, straight below, sometimes armed with three to four oral spines, sometimes forked. Ovicell smooth, sometimes porcellanous, grooved around the upper border, adnate to the front of the cell above.

Eschara Malusii, Audouin, Expl. i. 239; Savigny, Egypt. pl. 8. fig. 8.

Cellepora Macry, W. Thompson, Ann.\& Mag. Nat. Hist. x. 20 (not Chiaje?, nor M.-Edwards).

Lepralia biforis, Johnst. Hist. Brit. Zooph. ed. 2. p. 314. Herentia biforis, Gray, List Brit. Rad.p. 123.

Hab. Start Point, J. S. Bowerbank. Killinchy, Co. Down, $W$.

Thompson. Roundstone, id. S. Patagonia, 48 fathoms; T. del Fuego; Falkland Islands, Darwin. New Zealand, Dr. Lyall, R.N. On shells, stones and fuci.

As there can be no doubt of the identity of this species with that figured by Savigny, I have thought it right to apply Audouin's name. The species is so peculiar as to require no additional observations, unless it were to draw attention to the uncertain occurrence and form of the oral spines in it. The ovicell in the South American forms is of a brownish hue; and in all the specimens from that region the cells appear to be much larger than in the more common European form. The cells adhere to the object upon which the Lepralia is placed by means of a central flattened disc, and not by the entire surface (Ṕ. CIII. fig. 3).

43. Lepralia granifera. Pl. LXXVII. fig. 2. Pl. XCV. figs. 6,7 .

Cells ovate or elongated, walls usually thin and vitreous, with rare punctures, particularly round the margin; an umbo a short distance below the mouth, sometimes wanting, and above that a minute round pore ; mouth crescentic above, straight below, unarmed. Ovicell globose, raised, punctured.

Var. $a$. cornuta. A conical ascending process on each side of the mouth.

Lepralia granifera, Johnst. Hist. Brit.Zooph. ed. 2. p. 309. t. 54. fig. 7 ; Gray, List Brit. Rad. p. 118. 
? Flustra impressa, Audouin, Expl. i. 240 ; Savigny, Egypt.pl. 10. fig. 7; (non Lamarck, ii. 222; nor Moll, Esch. p. 51 . no. 7. pl. 2. fig. 9).

Hab. Coast of Ayrshire, Landsborough. Sidmouth, Mrs. Gatty. Holy Island and Berwick Bay, G. Johnston. Isle of Man, E. Forbes. Coast of Cornwall, Peach. Var. a. Lambay Island, W. Thompson. Portram, Ireland, Mrs. Gatty. On shells, stones and fuci.

44. Lepralia hyalina. Pl. LXXXII. figs. 1, 2, 3. Pl. XCV. figs. 3, 4, 5. Pl. CI. figs. 1, 2.

Cells subcylindrical, elongated or compressed and raised in front, suberect, the wall thin, transparent and smooth; mouth circular, frequently with a contracted, often subtubular sinus below, the upper or posterior margin much raised, sharp. Ovicell globular, erect, free, punctured.

Var. $\beta$. cornuta. With a thick short tubular process on each side of the mouth.

Var. $\gamma$. depressa. Cells flattened, adpressed, contiguous.

Cellepora hyalina, Linn. Syst. 1286; Fabric. Faun. Grcenl. 435. no. 442; Esper, Cellep. t. 1. figs. 1, 2; Lamx. Corall. 38; Bosc, Vers, iii. 148; Oken, Lehrb. Nat. 86 (non Cavolini nec Chiaje).

Berenicea hyalina, Hassall, Ann. \& Mag. Nat. Hist. vii. 367.

Cellepora personata, Chiaje, Mem. iii. 39. t. 34. figs. 17, 18, ovarian cell.

Escharina personata, Lamk. An. s. V. ii. 236. no. 24.

Lepralia hyalina, W. Thompson, Ann. Nat. Hist. v. 253; Johnst. Hist. Brit. Zooph. ed. 2. p. 301. t. 54. fig. 1.

Var. $\beta$. Wall of the cells thicker, calcareous and opake.

Lepralia cylindrica, Hassall, Ann. \& Mag. Nat. Hist. vii. 368. pl. 9. fig. 6.

Var. $\gamma$. Cells heaped, usually opake and calcareous.

? Cellepora ovoidea, Lamx. Corall. 38. pl. 1. fig. 1 ; Blainv. Act. 444 ; Lamk. Anim. s. Vert. ed. 2. ii. 259; Lamx. Exp. Méth. 2. t. 64. figs. 4, 5; D. Chiaje, Anim. s. Vert. Nap. iii. 38. t. 34. fig. 33 .

Celleporella hyalina, Gray, List Brit. Rad.p. 128.

$H a b$. Britain, common, on Laminaria and other fuci. Ireland, common, W. Thompson. Cornwall, Peach. Orkney, Lieut. Thomas, R.N. California, Dr. Sinclair. Cape of Good Hope, Harvey. W. Greenland, $73^{\circ} 20^{\prime}$ N., $57^{\circ} 20^{\prime}$ W. Var. $\beta$. California, Dr. Sinclair. Var. $\gamma$. E. Falkland Island, 4-10 fathoms, Darwin (Pl. CI. figs. 1, 2). 
45. Lepralia discreta. Pl. CI. figs. 3,4 .

Cells decumbent, cylindrical, ringed, widely distant and connected to each other by tubular processes; mouth contracted, orbicular. Ovicell decumbent, slightly keeled in front, flattened, and wider above, not punctured.

Hab. E. Falkland Islands, 4-10 fathoms. T. del Fuego, Darwin.

California, (from) Dr. Greville.

The three latter species, viz. L. hyalina, annularis and discreta, form a very natural group, with which $L$. granifera might not improperly be conjoined, and perhaps also L. tenuis.

\section{Lepralia annularis. Pl. XCV. figs. 1, 2.}

Cells decumbent, cylindrical, disposed side by side in concentric circular rows; mouth contracted, orbicular, with a strong tubular process on each side. Ovicell decumbent, acuminate, not punctured.

Eschara annularis, Moll, Seerinde, p. 39. pl. 1. fig. 4 ; Pallas, Elench. Zooph. p. 48. sp. 13 (sed sp. 9 huj. gen.); Boddaert in Pall. Belg. p. 59.

Escharina concentrica, Lamarck, ed. 2. ii. 237; Lamouroux, Polyp. Flex. p. 108.

Hab. Cape of Good Hope, W. H. Harvey. Algoa Bay. On fucus.

\section{Fam. 11. Celleporida.}

Polyzoarium composed of cells more or less vertical to its axis or plane, heaped together, or irregularly overlying each other.

\section{Cellepora.}

Polyzoarium calcareous, rigid, adnate or erect; composed of urceolate, suberect, contiguous cells, heaped together irregularly or arranged quincuncially. An ascending rostrum on one or both sides of the mouth, furnished with an avicularium.

Cellepora, sp., O. Fabricius, Faun. Groenl.; Johnst. Brit.Zooph. ed. 2. p. 295; Linn. System; Müller, Zool. Dan. Prod.; Berk. Syn.; Stewart, Elements; Lamarck, An. s. Vert. (part.); Lamouroux, Hist. Polyp. Flex. p. 85 (part.); Fleming, Brit. An.; Olivi, Zool. Adr.

Spongites, Oken, Lehrb. Nat. 85, 1815.

Tubipora (part.), Linn. Syst. Nat.

Millepora, Pall. Elenchus; Ellis \& Solander (part.).

Eschara (part.), Pallas, Elench. 
* Adnate, globose, or spreading.

1. Cellepora pumicosa. Pl. CX. fig.

Glomerous, cells heaped, ovate or pyriform; mouth orbicular ; rostrum large, pointed; avicularium, on the internal aspect, oval. Ovicell small, recumbent.

Porous Eschara, Ellis, Corall. 75. no. 7. pl. 27. fig. f, F. \& 72. pl. 30. fig. $d$, D.

Tubipora verrucosa, Linn. Syst. ed. 10. 789.

Cellepora pumicosa, Linn. Syst. 1286 ; Müll. Zool. Dan. Prod. 253; Berk. Syn. 1. 212; Stew. Elem. ii. 428. pl. 12. figs. 16, 17, copied from Ellis; Lamk. Anim. s. Vert. ii. 170, ed. 2. ii. 256; Lamx. Corall. 40 ; Flem. Brit. Anim. 532; Johnst. Trans. Newc. Soc. ii. 267; Templeton, Mag. Nat. Hist. ix. 469; Couch, Zooph. Cornw.48; Corn. Faun. iii. 110. pl. 20. figs. 4, 5 ; Johnst. Hist. Brit. Zooph. ed. 2. p. 295. t. 52. figs. 1, 2, 3; Gray, Hist. Brit. Rad. p. 129.

Cellepora verrucosa, Linn. Syst. 1286 ; Fabric. Faun. Grœnl. 434 ; Oliv. Zool. Adriat. 229.

Cellepora spinosa, Turt. Brit. Faun. 205.

Millepora pumicosa, Pall. Elench. 254; Ellis \& Soland. Zooph. 135; Jameson, Wern. Mem. i. 560 ; Stew. Elem. ii. 428.

Flustra bullata?, Ellis \& Soland. Zooph. 16; Stew. Elem. ii. 436. Madrepora verrucaria, Esper, Madrep. t. 17. figs. c, C \& b, B. $\mathrm{Hab}$. Britain and Seas of Europe, common. California, Dr. Sinclair. ? Bass's Strait, Macgillivray. ? Tasmanja, —?

2. Cellepora Hassallit. Pl. CIX. figs. 4, 5, 6 .

Cells cylindrical; mouth suborbicular or subquadrangular, lower lip mucronate, an ascending avicularium overlooking the mouth on each side. Ovicell punctured or striped, with a semilunar mark in front.

Cellepora bimucronata, Hassall, Ann. \& Mag. Nat. Hist. vii. 367. pl. 9. fig. 1 (non Lamouroux, Hist. Pol. Flex. p. 93).

? Eschara bimucronata, Moll, Eschar. p. 65. no. 15. pl. 3. fig. 18. Lepralia Hassallii, Johnst. Brit. Zooph. i. 304. pl. 54. fig. 3.

Celleporina Hassallii, Gray, List Brit. Rad. p. 128.

Hab. Coast of Ayrshire, Landsborough. Dublin Bay?, Hassall. On fucus and shells.

In a very beautiful and perfect specimen of this species, growing apparently on Laminaria, for which I am indebted to the kindness of Dr. Landsborough, the lower lip is produced into a very distinct and curiously formed mucro, and the structure of the lateral avicularia is remarkably well displayed. The cells are smooth and hyaline, and scarcely, if at all, ventricose, and I 
am therefore very much in doubt, with Dr. Johnston, whether this form is to be referred to the C. bimucronata of Lamouroux.

\section{Cellepora vitrina.}

Cells ovate, ventricose; mouth simple, orbicular; rostrum anterior, wanting in the marginal cells. Ovicell shallow, open in front, recumbent.

Cellepora ritrina, Johnst. Brit. Zooph. i. 300; Couch, Corn. Faun. pt. 3. p. 109. pl. 22. fig. 1.

Hab. Coast of Cornwall, not rare, Couch. Portaferry, Ireland,

$W$. Thompson.

The figure of this species has been accidentally omitted, but will be given, with others, in a supplementary part of this Catalogue.

4. Cellepora bispinata, n. s. Pl. CXX. figs. 1, 2.

Cells ovate, elongated, surface granular; mouth orbicular or subquadrangular; rostrum anterior, with a very minute avicularium on one side; two long oral spines on the opposite margin. Hab. Tasmania, Mrs. Smith; J. D. Hooker. On fucus.

5. Cellepora mamillata, n. s. Pl. CXX. figs. $3,4,5$.

Cells ovate, ventricose, immersed, forming an incrusting polyzoarium, the surface of which is studded with mamillary projections; mouth orbicular; rostrum large, conical, with a large avicularium on the internal face, sometimes a conical spine on the opposite side of the mouth.

Hab. Coast of Patagonia, Darwin.

\section{** Erect.}

6. Cellepora ramulosa. Pl. CiX. figs. 1, 2, 3.

Polyzoarium composed of dichotomous or irregularly dividing cylindrical branches. Cells ovate, slender; rostrum with a small avicularium on one side. Ovicell subglobose.

Cellepora ramulosa, Linn. Syst. 1285; Müll. Zool. Dan. Prod. 253; Flem. Brit. Anim. 532; Johnst. Trans. Newc. Soc. ii. 267. pl. 12. figs. 3, 4; Lamk. Anim. s. Vert. ed. 2. ii. 258; Thompson, Ann. \& Mag. Nat. Hist. vii. 481; Hassall, ibid. vii. 367 ; Couch, Zooph. Cornw. 49; Corn. Faun. iii. 110. pl. 20. fig. 2; Macgilliv. Ann. \& Mag. Nat. Hist. ix. 467; Johnst. Hist. Brit. Zooph. ed. 2. p. 296. t. 52. figs. 4, 5; Gray, List Brit. Rad.p. 129.

Cellepora pumicosa var., Pallas, Elench. 255; Ellis \& Soland. Zooph. 136.

Cellepora lævis, Macgilliv. Ann.\& Mag. Nat. Hist. ix. 467. $\mathrm{Hab}$. Britain, from Shetland to the South. 


\section{Cellepora Skenei. Pl. CXXiI.}

Polyzoarium much compressed, lobes bifid or trifid; cells ovate, subventricose, punctated, slightly raised; mouth orbicular, with a strong mucro in front, having an avicularium on its inner aspect near the apex.

Millepora Skenei, Ellis \& Soland.Zooph.135; Turt. Brit. Faun. 204 ; Stew. Elem. ii. 427.

Cellepora palmata, Flem. Brit. Anim. 532.

Cellepora Skenei, Johnst. Trans. Newc. Soc. ii. 267; Couch, Zooph. Cornw. 49; Corn. Faun. iii. 111 ; W. Thompson, Ann. \&. Mag. Nat. Hist. xv. 322 ; Johnst. Hist. Brit. Zooph. ed. 2. p. 297. t. 52. figs. 6, 7, 8; Gray, List Brit. Rad. p. 130.

Hab. Aberdeen, Skene. Zetland, Fleming. Coasts of Northumberland and Berwickshire, not rare, G. J. Off the Deadman, "rare," R. Q. Couch. Eastern coast of Ireland, Miss Ball. On shell.

8. Cellepora fusca, n. s. Pl. CXIX. fig. 2. Pl. CXX. fig. 6 .

Polyzoarium compressed, undulated. Cells ovate, ventricose, subimmersed, very irregular; mouth orbicular, with a raised, regular, or unevenly thickened margin; usually a strong rostrum on one side, with an avicularium on its inner aspect; numerous scattered avicularia, of various sizes and different forms, distributed over the polyzoarium. (Colour deep fuscous purple.)

Hab. Bass's Strait, Macgillivray.

Fam. 12. Escharide.

Polyzoarium erect, rigid, foliaceous and expanded, lobate or reticulated. Cells disposed quincuncially in the same plane, on one or both sides of the polyzoarium.

Escharidæ (part.), Johnst. Brit. Zooph. i. 329.

Lepraliana (part.), Gray, List Brit. Rad.p. 116, \& Reteporana, ib. p. 130 .

Synopsis of Genera.

* Cells on both sides.

1. Eschara.

** Cells on one side only.

2. Retepora. 


\section{Eschara.}

Polyzoarium foliaceous and expanded, or branched and sublinear. Cells disposed on both surfaces, back to back, immersed, coalescent, horizontal to the plane of the axis.

Eschara, Ray; Fleming, Brit. Anim. 531 ; Johnst. Brit. Zooph. ed. 1. 297, ed.2.350; Lamk. Syst. 375 ; Hist. ii. 173, ed. 2. 265 ; Gray, List Brit. Rad. p. 126.

Eschara, sp., Pallas, Zooph. 40; Moll.

Nullipora, sp., Solander.

Cellepora, sp., Esper.

* Polyzoary more or less expanded, foliaceous.

1. Eschara foliacea. Pl. CVI. figs. 4, 5, 6, 7.

Cells ovate or rhomboidal, obscurely punctured or granular; mouth contracted about the middle, with a small avicularium on the middle of the lower lip.

Eschara retiformis, Raii Syn. 1. 31; Flem. Brit. Anim. 531. Stony foliaceous Coralline, Ellis, Corall. 71. no. 3. pl.30. fig. a, A, B, c; Borl. Cornw. 239. pl. 24. fig. 6.

Eschara fascialis, Pall. Elench. 42 ; Moll, Seerinde, p. 36. pl. 1. fig. 2 .

Millepora foliacea, Ellis \&. Solander, Zooph. 133.

Millepora fascialis, Linn. Gm. p. 3785. sp. 14; Marsigli, Hist. phys. de la Mer, p. 148. t. 33. fig. 160.

Cellepora lamellosa, Esper, Cellep. p. 146. t. 6. figs. 1-5.

Eschara foliacea, Lamk. Anim. s. Vert. ii. 174, ed. 2. ii. 266; Blainv. Actinol. 428. pl. 75. fig. 3; Milne-Edwards, Ann. des Sc. Nat. vi.36.pl.3. fig. 1; Couch, Zooph. Cornw.60; Corn. Faun. iii. 131 ; Johnst. Hist. Brit. Zooph. ed.2. p. 351. t. 67 ; Gray, List Brit. Rad. p. 126.

$H a b$. Britain, common, especially on the south coast; Mediterranean, $M^{*}$ Andrew.

2. Eschara contorta, n. s. Pl. CVIII. figs. 1, 2, 3 .

Cells ovato-ventricose, punctured; mouth orbicular, with a small mucro in front, and an ascending, spathulate avicularium on each side ; usually one or two smaller avicularia on the front and sides of the body.

Hab. Algoa Bay. 
** Polyzoary divided into branching lobes.

3. Eschara urceolata, n.s. Pl. CV. figs. $4,5,6$.

Cells elongated, pitcher-shaped; surface granular; mouth subquadrangular; lower margin produced into a long conical rostrum, at the base of which, on the upper side, is a semicircular avicularium.

$H a b$. Algoa Bay.

4. Eschara platalea, n. s. Pl. CV. figs. 1, $2,3$.

Pl. CVIII. fig. 4.

Cells ovate, acute inferiorly, with a depressed area below the mouth in front, at the bottom of which is a simple pore. Avicularia irregularly scattered over the polyzoary, rare, with a spoon-shaped mandible.

Hab. Bass's Strait; off Cape Capricorn, Australia, Macgillivray.

5. Eschara lichenoides. Pl. CVI. figs. 1, 2, 3.

Cells ovate, punctured in the centre by three to four stellate pores, which soon coalesce into a single apparent opening; mouth suborbicular ; a small prominent avicularium on each side immediately below the mouth, looking outwards.

Eschara lichenoides, Milne-Edwards, sur les Eschares, p. 31.pl. 2. fig. 3; Lamarck, ed. 2. ii. 268; Seba, Mus. 3. t. 100. fig. 10; Lamouroux, Encyc. p. 375; Cuvier, Règ. Anim. ed. 2. t. 3. p. 316; Blainville, Man. d'Actinol.p. 428.

$H a b$. Bass's Strait; off Cape Capricorn ; between Cumberland Island and Point Slade (Australia), Macgillivray. Algoa Bay.

This appears so closely to accord with the description of $E$. lichenoides, M.-Edw., that I have little doubt it is that species; either this or the preceding certainly is, perhaps both.

\section{Eschara fuegensis, $n$. s. Pl. CVII. figs. 1, 2, 3.}

Cells pyriform, arched above the mouth; a central pore in front, and an avicularium pointing obliquely inwards and upwards on each side; mouth crescentic (in age the mouth becomes perfectly circular and very small, the cells and the interstices being covered and filled up with a perforated overgrowth). $H a b$. Coast of S. Tierra del Fuego, 30 fathoms, Darwin. 
7. Eschara decussata. Pl. CVII. figs. 4, 5, 6 .

Cells ovate, mostly separated by raised lines, between which and the central ovate portion of the front is a shallow sulcus; an avicularium with an acute mandible pointing upwards on the middle immediately below the subcrescentic mouth.

Eschara decussata, $M$.-Edw., Lamk. ed. 2. ii. p. 267; $M$.-Edw., sur les Eschares, p. 40. pl. 4. fig. 2. Hab." Seas of Australia, Macyillivray.

Whatever obscurity may attach to $E$. lichenoides, M.-Edw., there can be no doubt about the present species being the one intended by that author.

8. Eschara flabellaris. Pl. CVII. figs. 7, 8, 9, 10.

Polyzoary flabellate, attached by a flexible stem composed of horny tubes. Cells ovato-ventricose, punctured; a crescentic pore a little below the mouth, and an avicularium on the side and upper part of the cell; mandible acute, pointing directly outwards. Ovicells globose, prominent, subgranular or smooth. Hab. Algoa Bay.

9. Eschara gracilis. Pl. CVIII. figs. 5, 6,7.

Polyzoary composed of slender, slightly compressed, subcylindrical branches. Cells deeply immersed, pyriform, bulging above; an elongated central pore (? avicularium); in the quite young cells a mamillary projection on each side a little below the mouth; mouth orbicular, with a minute denticle below.

Millepora tenella, Esp. Suppl. i. t. 20.

Eschara gracilis, Lamouroux, Encyc. p. 375; Blainville, Man. d'Actinol.p. 428 ; Lamarck, An. s. Vert. ii. 268. ed. 2 ; M.Edwards, sur les Eschares, p. 28. pl. 2. fig. 2.

Hab. Bass's Strait, parasitic on Catenicella elegans ; Macgillivray.

The closed cells noticed by M.-Edwards are not improbably ovicells.

10. Eschara gigantea, n. s. Pl. CXIX. fig. 3.

Polyzoary very thick and solid, lobes wide, undulated. Cells smooth, solid, ventricose, ovate or subhexagonal, immersed and coalescent; a deep penthouse-like projection above the mouth, the lower lip of which projects.

Hab. South Patagonia, Darwin. 
11. Eschara cervicornis. Pl. CIX. fig. 7. Pl. CXIX. fig. 1.

Polyzoary much branched, compressed. Cells at the growing extremities ovate, elongated; mouth orbicular, lower margin sinuated and projecting, with a semicircular avicularium within the sinus. In the older parts of the polyzoary the cells are deeply immersed, the mouth often subtubular and projecting, or immersed and sinuated below with the avicularium as above.

? Poro cervino, Imperato, Hist. Nat. p. 630 (1572); ? Bonanni, Museum Kirch. p. 286. fig. 13 (1709).

? Porus cervinus minor, Marsigli, Hist. physique de la Mer, (1525) p. 63. pl. 32. fig. 152.

Millepora cervicornis, Ellis \& Solander, (1786) p. 134 ; Pallas, Elenchus Zoophyt.; Stewart's El. ii. p. 427; Turton, Brit. Fauna, 204.

Millepora compressa, Sow. Brit. Miscell. 83. pl. 41; Jameson, in Wern. Mem. i. 560 ; Oken, Lehrb. 86 ?

Eschara cervicornis, Lam. Hist. Nat. des An. s. V. ed. 2. ii. 267 ; Lamouroux, Encycl. p. 374 ; Blainville, Dict. d. Sc. Nat. xv. 297, \& Man. d'Actinologie, p. 428 ; M.-Edwards, Sur les Eschares, p. 15. pl. 1, \& pl. 2. fig. 1.

Cellepora cervicornis, Couch, Zooph. Cornw. 49 ; Cornish Fauna, pt. 3. p. 111. pl. 20. fig. 1 .

Porus cervinus, Borlase, Cornw. 240. t. 24. fig. 7 (not Marsigli). Millepora alcicornis, Esp. Millep. t. 5, 6, 7.

Hab. Start Point? from J. S. Bowerbank.

From the figures of Cellepora cervicornis given (Brit. Zooph. pl. 53), that species would appear to differ from the present, not only in habit, but more particularly and importantly in the shape of the oral apertures in the older or immersed portions of the polyzoary. In the specimen from which the figures in this Catalogue were taken, and the present description drawn up, the characters so exactly accord with those assigned to it and figured by M. Milne-Edwards, that I cannot entertain a doubt upon the identity of the form 1 have had before me and the one he has in view. The exact habitat of my specimen is unfortunately not quite certain : I have it marked Britain, but am not sure whether Mr. Bowerbank procured it, or had it from the coast of Devon, or from the Orkneys or Shetland ; in any case, however, it is a British species, and until further evidence is offered of another much-resembling form, I must entertain grave doubts as to the existence of a distinct one so nearly allied as that figured in Hist. of Brit. Zoophytes; and this notwithstanding the opinion of M. Milne-Edwards to the contrary (l. c. p. 16).

It is to be remarked, that in the older parts of the polyzoary of my specimen, the surface presents numerous protuberant 
cells, scattered irregularly over it, and which if multiplied, as under circumstances it is quite conceivable they might be, would afford the heaped or confused aspect and structure of the genus Cellepora, and make it accord with figs. 4 \& 5 of Dr. Johnston's plate. The genus requires further research.

\section{Retepora.}

Polyzoarium foliaceous, calcareous, reticulated. Cells immersed, opening on one surface only.

Millepora, Linn. (part.) ; Ellis \& Solander; Esper ; Marsigli, Hist. ; Cuvier, Règn. Animal (spec.).

Retepora, Imperato, Hist. Nat.; Lamarck, ii. 274; Risso, L'Europe Mérid.; Flem. Brit. An. ; Stark, Elem. ii.; Blainv. Actin.; Couch, Corn. Faun.; Johnst. Brit. Zooph. i. 353; Goldfuss (part.) ; Hagenow (part.).

? Frondipora, Oken, Lehrb. 63, 1815; Blainville, M. d'Actinologie.

1. Retepora cellulosa. Pl. CXXI. figs. 3-8. Pl. CXXili. figs. 5,6 .

Polyzoarium turbinate or crateriform, undulated, curled, rising, with a sort of peduncle. Cells subcylindrical ; a prominent rostrum in front of the mouth, having a minute avicularium on one side at the base; a marginal spine on each side of the mouth; scattered avicularia of various sizes and forms dispersed over the polyzoarium.

'Stony Eschara' of Imperatus ' full of holes like a net,' Ellis, Corall. p. 72 . pl. 25 d, D, F.

Retepora eschara marina, Imperato, Hist. Nat. p. 630 (cited by Ellis).

? Millepora cellulosa, Jameson, Wern. Mem. i. 560; Turt. Brit. Faun. 205; Stew. Elem. ii. 427; Cavolini, Pol. Mar. p. 64. pl. 3. figs. $12 \& 13$.

Millepora foraminosa, Ellis \& Soland. Zooph. 138. pl. 26. fig. 2. Frondipora cellulosa, Oken, Lehrb. Nat. 63.

Millepora Retepora, Borl. Cornw. 240. pl. 24. fig. 8; Pallas, Elench. p. 243.

Retepora reticulata, Johnst. Hist. Brit. Zooph. ed. 2. p. 353 ; Couch, Corn. Faun. iii. 130.

? Frondipora reticulata, Blainv. ibid. 406. pl. 69. fig. 1.

? Frondipora clathrata, Oken, Lehrb. Nat. 64.

Manchette de Neptune, Daubenton, Ic. t. 23. 
Retepora cellulosa, Lamouroux, Exp. Méth. des Polyp. p. 41. pl. 26. fig. 2 ; Deslongchamps, Encyclop. Zooph. p. 669 ; Cuvier, Règne Anim. ed.2. iii. 316; Schweigger, Handb.p.431; Blainv. Man. d'Actin. p. 433. pl. 76. fig. 1; ? Reuss, Fossil Polyp. d. Wien. Tertiar-Beckens, p. 47. pl. 6. fig. 34 .

? Retepora frustulata, Lamarck, l. c. p. 279.

? Retepora vibicata, Goldfuss, Pet. Germ. i. 103. t. 36. fig. 16. Hab. Mediterranean. Britain? Cape Horn, 40 fathoms, Darwin. Australian Seas (a more slender variety?), Macgillivray.

2. Retepora beaniana. Pl. CXXIII. figs. 1-5.

Polyzoarium infundibuliform, wavy, on a short peduncle. Cells subcylindrical ; a prominent rostrum in front of the mouth, on the point of which is a semicircular avicularium, and from which a slightly raised keel descends upon the front of the celi, which therefore appears to be hollowed on the sides; a spine on each side of the mouth.

Millepora cellulosa, Jameson in Wern. Mem. i. 560; Turton, Brit. Fauna, 205; Stew. Elem. ii. 427.

Retepora cellulosa, Johnst. in Loud. Mag. Nat. Hist. vii. 638. fig. 69; S. V. Wood, Ann. \& Mag. Nat. Hist. xiii. 16;W. Thompson, ibid. xv. 322 .

? Retepora beaniana, King in Ann. \& Mag. Nat. Hist. xviii. 237 ; Landsborough, Pop. Hist. Brit. Zooph. p. . pl. . fig. $H a b$. Shetland Islands and in the Island of Fulah, Jameson. Scarborough, $W$. Bean. ? Cape Clear, Ireland, Prof. Allman. Orkneys, E. Forbes, Barlee. Deep water off the coast of Northumberland, $W$. King.

The very minute difference between the two foregoing species, unless proved to be constant, is hardly sufficient to render them distinct; and although I have here so arranged them, I am by no means satisfied that it is correct. There is a considerable difference in the habit of the Australian form, but very close investigation has failed in my hands to establish any other definable distinction. The figure, of the natural size, here given, is taken from a magnificent specimen taken in Embleton Bay, Northumberland, and in the possession of Mr. Alder.

3. Retepora phonicea, n. s. ? Pl. CXXI. figs. 1, 2.

Polyzoary foliaceous, expanded, much convoluted. Cells ovate, ventricose ; mouth raised, circular, sometimes subtubular, entire or irregularly serrated; cells where immersed bordered by a raised line; many cells with an avicularium placed obliquely on the front, just below the mouth; mandible very wide at the 
base and acuminate. Ovicells immersed (in the young state covered in front by a concentrically marked operculum). (Colour purple.)

Hab. Bass's Strait, Macgillivray.

This is doubtless one of the forms alluded to by Lamarck (l. c. p. 277) as brought by Péron and Lesueur from the Indian Seas, and as of a purple colour; and may probably be the species figured in Rumph. Amboin. 6. t. 87. fig.5.

Fam. 13. Vinculariada.

Polyzoarium rigid, calcareous, unarticulated; cells disposed alternately around an imaginary axis, forming dichotomously dividing branches. Surface of polyzoary not areolated. The family includes (among many other fossil forms) -

Vincularia, Defrance, Dict. d. Sc. Nat.; Blainville; Hagenow, Bryoz. d. Maest. Kreideb. p. 59.

Glauconoma; Goldfuss, Petrefact. Germ.

Siphonella, Hagenow (l. c.) p. 83.

Cellaria (part.), Reuss, Fossil Polyp. d. Wien. Tertiar-Beckens, p. 58.

Three families of cheilostomatous Polyzoa, characterized by a polyzoarium formed of cylindrical branches in which the cells are disposed around an imaginary axis, are given in this Catalogue. In the first of these (Part I.p. 15), the SALICORNARIAD \&, the branches are articulated by flexible joints, and the ovicells are deeply immersed. In the second, the FARCiminariadas (p. 32), the polyzoarium is continuous throughout, and the ovicells are prominent and globose; the structure moreover of the only species referred to it is corneous and flexible. In the third, termed the Vinculariad A, and as here constituted, the polyzoarium is also continuous throughout, but the structure is calcareous and rigid, and the ovicells are inconspicuous or deeply immersed.

Whether these distinctions are sufficient to constitute family groups may be a matter of dispute, but, from analogy with other groups of Polyzoa, I think that the articulation or non-articulation of the polyzoary is an important (artificial) character; and with respect to the Farciminariada, the distinction between the soft and flexible $F$. aculeata and the forms (fossil) included under Vincularia and its allies, appears to be too marked to allow of their association, independently of the different position of the ovicells.

The genus Vincularia, to which I have referred the species 
represented in $\mathrm{Pl}$. LXV. fig. 2, has hitherto been known only in certain fossil forms, the composition of which, as is observed by M.-Edwards (Lamarck, Hist. d. An. s. Vert. ed. 2. ii. 193), is " essentially the same as that of the Salicornaria of Cuvier:" but he goes on to say, " as only very minute fragments of them have been found, it is unknown whether the cylinders resulting from the coalescence of a certain number of longitudinal rows of cells are articulated or not; in the latter case the proposed generic division should be retained, whilst in the opposite there would be no sufficient reason to separate them from Cellaria (Salicornaria) properly so called.

The occurrence of a recent species clears up this point, if it were not sufficiently evident before, and I am therefore so far supported, in the distinction of the group from the Salicornariada. The same value appears to be attached to this character also by Hagenow (l.c. p. 59); and from a note in page 60 it would appear that Prof. Philippi is now of the same opinion.

\section{Vincularia.}

Branches of polyzoarium not tubular ; front of cells surrounded by a raised border, arcuate above, nearly straight below. Ovicells immersed, opening above the mouth of the cell upon which they are placed.

3. Vincularia ornata. Pl. LXV. fig. 2.

- Margin of cell much raised, granular ; lamina granular, irregularly denticulate on its internal edge.

Hab. Patagonia, Darwin.

It would appear that the present species belongs more to the type common in the cretaceous formation than to that met with in the tertiary; that is, to those Vincularice in which the cells are surrounded with a border; whilst, according to Hagenow (l. c. p. 60) and Reuss, the forms probably referable to the same family group, though perhaps not to the same genus, the species with ventricose, oval cells, e.g. (Cell. duplicata, labrosa, Michelini, coronata, Schreibersi, \&c., Reuss, l. c.), are peculiar to the tertiary rocks. This observation, however, will hardly hold good with respect to such forms as Cell. macrostoma, Reuss, l.c. pl. 8 . figs. 5, 6; Cell. Haidingeri, pl. 7. fig. 30; Cell. cucullata, pl. 7 . fig. 31 ; Cell. exarata, pl. 7 . fig. 32 ; all of which appear to me to belong to the true Vincularia.

The proper comparison, however, not only of these, but of all fossil forms of Polyzoa, with recent ones, yet remains to be made. 


\section{Fam. 14. Selenariade.}

Polyzoary more or less regularly orbicular, convex on one side, plane or concave on the other, probably free. Furnished with large and powerful vibracula (probably locomotive) (often having arenaceous particles affixed in the centre of the under surface).

\section{- Synopsis of Genera.}

1. Each cell with a vibraculum at its apex.

1. Cupularia.

2. The cells and vibracula in alternate rows radiating from the centre.

2. Lunulites.

3. Certain of the cells only, furnished with vibracula.

3. Selenaria.

1. Cupularia.

Each cell throughout the polyzoarium with a vibracular cell at its apex.

Cupularia, Lamouroux, Exposit.p. 44 (proposed).

Lunulites, id. ib. (part.); Defrance, Dict. des Sc. Nat. (part.); Deslongch. Encyclop. Zooph. B. (part.); Goldfuss, Petrefact. Germ. (part.); Blainville, Man. d'Actin. (part.); Gray, Spicilegia Zoologica, pt. 1. p. 8; Cuvier et Brongniart, Descript. géolog. des Environs de Paris (part.); Lonsdale, Miocene Fossils from N. America, Journal of Geol. Society, i. 503 (not Eocene Fossils, ib. p. 531); Michelin, Icon. Zoophyt. (part.).

Fenestella, Lonsdale (Append. Geol. of Russia) (part.).

Besides the peculiar formation of the polyzoary, all the Selenariada are distinguished by the circumstance that the cells of which it is constituted are of two kinds, usually differing in size, the one being smaller than the other. The distinction between the different genera into which I have thought it convenient to divide the family is derived solely from the different relative position of these two kinds of cells to each other, or to the entire polyzoarium. The propriety of the division of the Lunulite group into two genera appears to have occurred to Lamouroux, 
and as one of the subdivisions for which he proposed the name Cupularia coincides with the one of those into which I believe it naturally falls, that name has been retained. The same division of the genus Lunulites, as originally constituted, is suggested by Mr. Lonsdale's observations with respect to Lunulites denticulata (l. c. p. 503), and it is consequently sufficiently apparent that the generic divisions here adopted will apply equally to fossil and to recent forms. The examination of the former alone, however, would never have led to the proper appreciation of the characters here employed, because, from fossil specimens, it was impossible to arrive at any satisfactory elucidation of the respective nature of the two kinds of cells. Mr. Lonsdale hints (l. c. p. 504) that the secondary pores or small chambers in the quincuncial species offer a perfect analogy with the chambers in Eschara and Escharina, "supposed to be receptacles for maturing gemmules;" but in this, as I have fully ascertained from the examination of numerous recent species, he is mistaken. The secondary chambers are the cells of vibracula, and in the living state contain probably nothing but the muscular apparatus for the movement of a very long and strong vibracular organ. Where the true ovicells are, if such organs exist in this family, I have been unable to perceive; but that the smaller cells in question are of the nature I have mentioned will be sufficiently obvious on inspection of almost any of the figures here given. As the present part of this Catalogue is limited to recent species, no mention is here made of fossil ones, of which a future opportunity will be taken to speak.

To facilitate the description of the species, it will be as well to define certain terms, which it is convemient to employ.

1. Area of cell means the space occupied by the front of each cell, which is bounded by a raised line.

2. Lamina is the calcareous expansion which partially forms the anterior wall of the cell, the rest being occupied by a membranaceous or horny layer, as in Membranipora.

3. Aperture is the opening or space thus left unfilled by the calcareous lamina, in the upper end of which, or that furthest from the centre of the polyzoary, is the true mouth, with the moveable lip, which is for the most part removed with the horny layer.

4. Vibracular opening is the opening of the cell containing the muscles for the movement of the vibraculum.

\section{Cupularia guineensis, n. s. Pl. CXIV.}

Polyzoary orbicular, in section crescentic; area of cell rhomboidal, aperture ovoid, lamina granular; vibracular opening au- 
riform, entire, with a slight elevation on one side. Under surface of polyzoary divided into hexagonal areas, each corresponding to a cell.

Hab. New Guinea. B.M. Collection.

\section{Cupularia Owenit. PI. CXV.}

Polyzoary orbicular, depressed ; area of cell rhomboidal, subelongated ; lamina finely granular; aperture irregular, margin jagged; vibracular opening suboval, entire; under surface of polyzoarium marked with bifureating sulci, and each ridge with a median line.

Lunulites Owenii, Gray, Spicilegia Zoologica, pt. 1. p. 8. t. 3. fig. 15 (1828).

$H a b$. Coast of Africa.

This species appears to differ from Lunulites denticulata (Conrad, Silliman's Journal, Oct. 1841, xli.) mainly in the more depressed form of the polyzoary. But 1 think this difference is quite sufficient to render the identity of the two forms more than problematical. The American species appears, in respect of its conical form and other characters, entirely to correspond with what has been termed $L$. Owenii of the Coralline Crag; and notwithstanding a former opinion to the contrary, I am now inclined, for several reasons, to believe that the fossil must be regarded as distinct from the recent form.

\section{Cupularia lowei. Pl. CXVI.}

Polyzoarium irregular in outline; area of cell rhomboidal, wide; no aperture; lamina cribriform or granular, or nearly smooth, according to age; vibracular opening auriform, entire, with an elevation on one side; mouth crescentic, with a straight lip below, margin raised.

Lunulites Lowei, Gray, MSS.

Hab. Madeira, Lowe.

4. Cupularia stellata, n. s. Pl. CXVili.

Polyzoarium orbicular, depressed, deeply serrated at the margin; area of cell suboval or subrhomboidal ; lamina narrow and smooth or wanting; aperture oval or elliptical ; vibracular opening small, with a prominent tooth on one side, below which is a sinus.

$H a b$. Philippine Islands.

The cells are deeper than they appear in the drawing, and the inner lamina should be less decidedly expressed. 


\section{Cupularia pyriformis, n. s. Pl. CXXIV.}

Polyzoary subconical or depressed, stellate; cells pyriform; upper part raised, contracted; margin of aperture thin, smooth ; an internal lamina, the lower border of the opening in which is straight; under surface deeply grooved, ridges carinate, obscurely punctate, with a single row of dots on either side.

$H a b$. St.Vincent. Collection B.M.

At first sight this species offers a close resemblance to the preceding, from which, however, it differs in several respects. Among which are-1. the raised and free superior extremity of the cell, the contracted neck between the vibracular opening and the aperture of the cell; 2 . the thin overlapping margin of the aperture ; and 3 . the punctation, though obscure, on the posterior surface. Both species appear to grow upon arenaceous particles.

\section{Lunulites.}

Cells arranged in series radiating from the centre and bifurcating as they advance; vibracula in linear series alternating with those of the cells.

Syn. as for Cupularia (part.).

The observations given under the preceding genus are equally applicable here; it is necessary in addition merely to remark, that it is probable the vibraculum itself in this genus is distinguished by having a bifid or trifid extremity; and that it is not unlikely, from the length, strength and disposition of these organs, that they may be employed for the purpose of locomotion as well as of defence.

\section{Lunulites gibbosa, n. s. Pl. CXI.}

Polyzoary very irregular in its form; area of cell arched above, straight below; margin granular; no lamina; vibraculum bifid or trifid at the extremity; under side of polyzoary nearly even, marked with faint lines, punctured, punctures in single or double series on each ridge.

Hab. Off Cape Capricorn, Macgillivray.

2. Lunulites capulus, n. $\mathbf{s}$. Pl. CXII.

Polyzoary conical, much raised; area of cell semilunar or arched above, straight below, with a small bifid denticle within 
the lower margin; margin granular; vibracula trifid at the extremity ; under surface of polyzoary grooved, ridges punctured with a single row of openings.

Lunulites capulus, Busk, Voy. of Rattlesnake, i. pl. 1. figs. 13, 14. Hab. Off Cape Capricorn, Macgillivray.

3. Lunulites philippinensis, n. s. Pl. CXIII. figs. 1, 2, 3.

Polyzoarium subconical, serrate at the edge, flat beneath and porous, pores umbilicate ; opening of cell pyriform, margin not raised; vibracular opening minute, circular.

$H a b$. Philippine Islands.

4. Lunulites cancellata, n. s. Pl. CXIII. figs. 4, 5, 6, 7 .

Polyzoarium conical, raised, flat beneath and the centre perforated by numerous umbilicate openings ; internally cancellated; opening of cell circular, with a simple raised margin ; vibracular openings minute, oval, oblique.

$H a b$. Philippine Islands.

This species and the one immediately preceding are very curious forms and would appear to constitute a peculiar group, characterized by the circumstance that the concave side of the polyzoary is more or less filled up by a cancellated structure.

\section{Selenaria, n. g.}

Only a certain number of cells dispersed throughout the polyzoary furnished with vibracula. The front of each cell, so furnished, covered by a cribriform calcareous expansion; others arched above, contracted below; under surface of polyzoary marked with grooves.

1. Selenaria maculata, n. s. Pl. CXVII.

Polyzoary orbicular, on section crescentic ; vibracula contorted, finely ringed.

Lunulites maculata, Busk, Voy. of Rattlesnake, i. pl. 1. figs. 15, 16. Hab. Bass's Strait. 


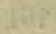

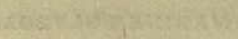

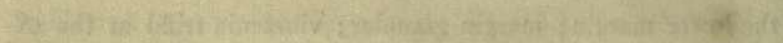

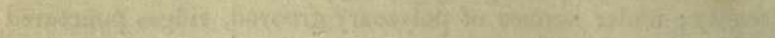

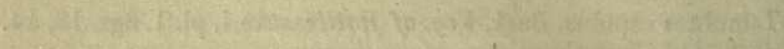

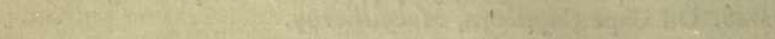

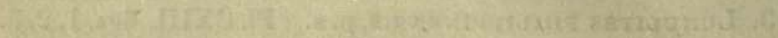

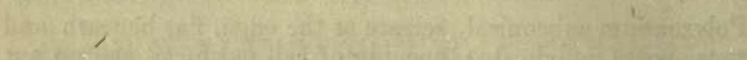
Thater.

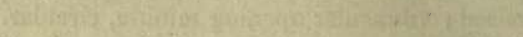

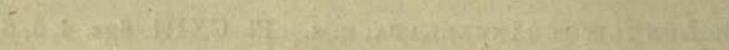

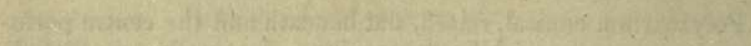

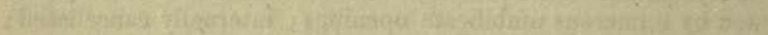

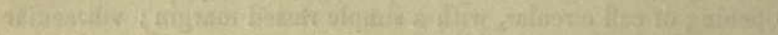

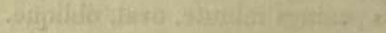

74.5.

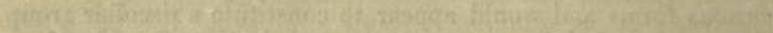

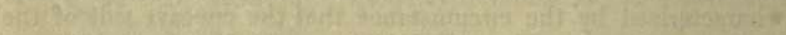

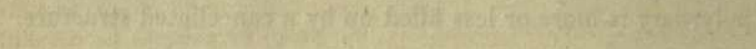

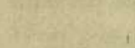

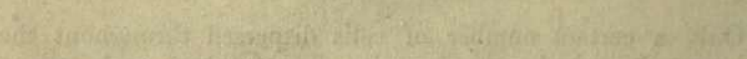

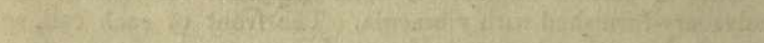

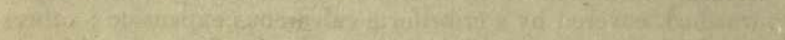

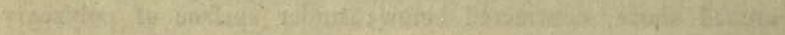

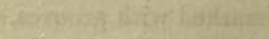

i.

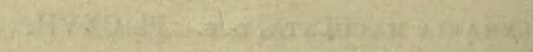

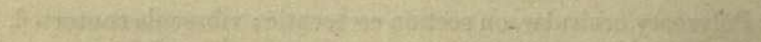
37.

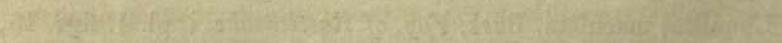

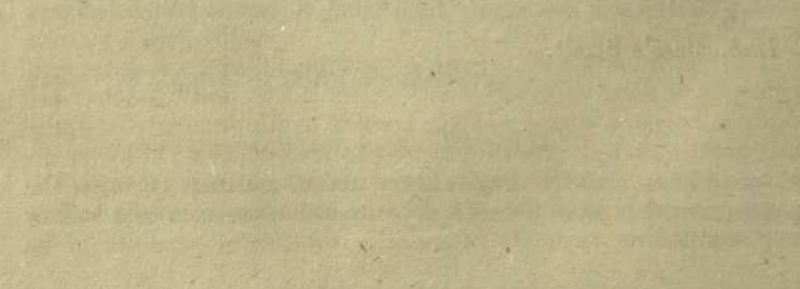




\section{OBSERVATIONS}

ON THE

\section{AVICULARIAN AND VIBRACULAR ORGANS}

OF THE

POLYZOA.

In the characters of the species of cheilostomatous Polyzoa contained in the foregoing two Parts of this Catalogue, considerable use has been made of the avicularian and vibracular organs, the possession of which appears, so far as I know, to be peculiar to that Suborder. I have therefore thought that it might be useful to subjoin a few observations on the subject of these organs, for the purpose of indicating how far our knowledge of them at present extends, and of directing attention more particularly to their value as affording diagnostic or systematic characters. Much of the following observations is taken from a paper recently published in the Transactions of the Microscopical Society, with which figures are given illustrative of the subject.

The organs in question are of two kinds, the one forming a sort of pincers, and the other consisting of a long, slender, moveable seta, and the muscles by which it is moved contained in a special receptacle or cell.

To the former set of organs, of whatever form, the term avicularium is here understood to be applicable, and the latter are designated as vibracula. With respect to the structure of these organs of either class it is sufficient to remark, that, however diverse their appearance may be, they are all constructed upon the same general type, that is to say, the organ consists of a hollow cup, containing two sets of muscles for the movements of its 
motile portion, the mandible, as I have termed it in the one case, and the seta in the other.

The avicularium, besides the moveable mandible, which varies extremely in form and length, always has a more or less wellmarked, corresponding fixed beak, the opponent as it were of the mandible and serving to constitute the organ an instrument of prehension.

This beak is necessarily absent in the vibraculum, which appears to be merely a defensive organ, or perhaps in some cases (as in the Selenariada) having a locomotive function, and its absence in cases where the moveable part of the organ is detached would serve to distinguish the one kind of organ from the other. It is to be regretted, bowever, that in the instance of fossil species, where such a character would often be of extreme value, this beak, which is, I believe, always constituted of a horny or chitinous substance, is removed together with all other vestiges of the animal tissues. The presence of a beak also serves to determine in some cases the avicularian nature of the organ, when, as in several species of Lepralia, the setose form of the mandible might indicate that it would be more correctly referred to the vibracular type.

1. As regards the avicularia.

These organs, which appear to have been first noticed by Ellis, have been investigated and described by many subsequent authors, among whom are particularly to be noticed Mr. Darwin, Dr. Van Beneden, the late Professor John Reid, and especially Nordmann and Krohn.

In some observations upon the structure of the polyzoary and other points in the economy of Notamia bursaria, published in the Transactions of the Microscopical Society for 1847, I described more particularly the structure of the curious and unique form presented by the avicularium in that Polyzoan, pointing out I believe for the first time, that the muscles were divisible into two distinct sets, one for the closure and the other for the opening of the mandible; I also indicated that the mandible and beak were constituted of a different substance to the rest of the organ, as above adverted to; and that, besides the two sets of muscles, the cup contained a "peculiar body of unknown nature."

I have in addition only to remark that since then it has occurred to me to notice a circumstance hitherto overlooked, and which may eventually serve to throw some light upon the " peculiar body" contained in the cell to which I adverted in my observations on Notamia. It was in that species, also, that I first noticed the fact that when the mandible is thrown back, or in other words, when the avicularium is open, a slight prominence comes into view, covered with delicate seta, which do not seem 
to be of the nature of cilia, because they exhibit no motion. These minute seta appear to be seated on the "peculiar body," or at all events to be moved with it, and the latter again seems to be so connected with the muscles by which the mandible is closed, or rather perhaps to a membrane by which the opening of the cell is covered when the mandible is thrown back, as to be protruded simply by the throwing back of that process. The sete then project beyond the level of the cup, and are withdrawn into it as the mandible closes. I have noticed this arrangement at present only in three species of Polyzoa, viz. Notamia bursaria, Bugula plumosa, and B. avicularia. In Scrupocellaria scruposa, the only other species that I have had a sufficient opportunity of examining in the living state, I failed in detecting it, and am therefore not prepared to assert that it obtains universally. The seta might be supposed to constitute a tactile organ, the object of which would be to apprise the occlusor muscles of the contact of any minute floating object, upon which the mandible is then suddenly closed.

With respect to the function of the avicularia, several circumstances, independent of their conformation, conspire I think to show that they are probably organs of prehension.

Their structure so obviously indicates an aptitude for prehension, that the supposition of such being their function has long been entertained. This prehension of objects may be either for the purposes of defence, or more probably for the procuring of food, for, as Dr. Johnston observes, "although they are too short to hand the prey to the mouth, yet retained in a certain position, and enfeebled or killed by the grasp, the currents set in motion by the ciliated tentacula may then carry it within reach." The prehension of living objects by these organs has been repeatedly observed ; and on one occasion I witnessed the capture of a minute vermicule, by two of the avicularia, simultaneously, on opposite sides of a branch of Scrupocellaria scruposa, and its retention by them for several days, notwithstanding the continued and vigorous efforts of the victim to escape.

With respect to the vibracula, 1 would merely observe, that they consist of a cup containing the muscular apparatus, and of a moveable seta articulated to the cup, and which appears to be moved in the same way as the mandible of the avicularia. This seta is in most cases simple and terete; whilst in others, as for instance generally in the genus Caberea, it is toothed on one side; and in others, as in the family Selenariada, the seta is very variously and curiously formed ; in some being bifid or trifid at the extremity; and in one, Selenaria maculata (PI. CXVII.), it is spirally contorted and minutely annulated, so as very closely to resemble the proboscis of a butterfly. 
As to the function of the vibracula, it would appear in most cases to be simply defensive. The seta may be observed in almost continual motion, sweeping slowly and carefully over the surface of the polyzoary, and removing what might be noxious to the delicate inhabitants of the cells when their tentacula are protruded.

Another circumstance, however, often to be observed with respect to these organs, is this, that each presents inferiorly a perforation sometimes rounded, as in Scrupocellaria and Canda, sometimes channelled as in Caberea, which indicates the point of attachment of a radical tube or fibre. But that this connexion with a radical tube is not an essential attribute of the vibracular organ, is sufficiently obvious from the circumstance that those tubes are frequently found when no such organs exist; whilst on the other hand, where there are vibracula, the tubes invariably enter them, and not the cell itself. This is especially evident in the genus Canda.

In the case of the Selenariada or Lunulites, I think it not improbable, as above remarked, that the vibracula may be subservient to locomotion. This point and others would form a most interesting subject of observation to those who may be fortunate enough to obtain these remarkable creatures in the living state.

The avicularian and vibracular organs appear to be of very considerable importance in a systematic point of view; and although from our imperfect knowledge of them, and, in fact, of many points in the economy and structure of the Polyzoa in general, the supposition can only be regarded as highly problematical, it seems not unlikely that their presence or absence, especially of the avicularium, may be connected more directly with the intrinsic nature of the species upon which they are found, than has hitherto been supposed. It may, for instance, be the case that those furnished with these offensive weapons live upon a kind of food different from that of the others, who do not require such an aid in the capture or weakening of their prey. The Polyzoa may, perhaps, thus be divided into vegetable and animal feeders; or into feeders upon dead, and those which subsist upon living organisms. One thing, however, may be affirmed, that these organs afford, in many cases, excellent and available systematic characters, of which application of them the preceding Catalogue will afford abundant evidence; with respect to this part of the subject it will therefore be unnecessary here to add more than a few words.

Of the two sets of organs, the avicularia are found by far the most extensively; existing in fact in the majority of genera constituting the cheilostomatous Polyzoa. In employing 
these appendages for the purpose of classification it is necessary to subdivide them into three classes: 1 . the pedunculate; 2 . the sessile; 3 . the immersed. the two latter classes, however, run insensibly into each other, whilst the pedunculate form is obviously quite distinct, inasmuch as it presents an additional member in the form of a basal joint. It is to this form of avicu. larium that the term "bird's" or "vulture's heads" is more properly applied. It occurs in Bugula avicularia, B. plumosa, B. fabellata, B. dentata, and in Bicellaria ciliata; whilst it is wanting altogether in Bugula neritina, Bicellaria grandis and $B$. gracilis, species therefore which it is very desirable should be examined in the living or fresh state, for the purpose of determining whether the inhabitant of the cell does not afford characters sufficient to cause these species to be referred to genera distinct from those to which, from consideration of their skeletons alone, they are now regarded as belonging. A modification of pedunculate avicularium, where it assumes the form of a long trumpet-shaped or infundibuliform organ, exists in Bicellaria tuba. With the exception of this latter form, the pedunculate avicularia are always placed on the anterior aspect of the cell, on one side below the level of the aperture.

The sessile form of avicularium, distinguished from the immersed, is pretty extensively met with, though it does not occur so abundantly as the latter form. With a single exception (Amastigia nuda, Pl. XXXVI.), this form of avicularium is almost invariably placed upon the front of the cell below the aperture, as in Alysidium Lafontii (PI. XIV.), most species of the genera Menipea, Scrupocellaria and Canda, and in many of the genus Caberea ; in some, as in Scrupocellaria ferox (Pl. XX11.), attaining gigantic dimensions. It is distinguished from the immersed form of avicularia, not only by its greater projection, but also, and perhaps more essentially, by its being composed of a more or less flexible material; whilst in the latter form, even where it is somewhat prominent, the cup is always calcareous and rigid.

The immersed form of avicularium occurs in a great number of genera and species, and in many instances, as in the genus Lepralia, affords excellent specific characters. The variety of appearances and position assumed by this form of avicularium will be best appreciated upon inspection of the figures, especially of the genera Catenicella, Scrupocellaria, Menipea, Caberea, Lepralia, Cellepora, Eschara, Retepora, Emma, Salicornaria and Flustra. In Diachoris crotali, Notamia bursaria and Bicellaria tuba, the avicularium presents such an aberrant conformation, that it can scarcely be arranged in either of the above categories. That of Diachoris crotali and Bicellaria tuba, how- 
ever, may I think be placed with the pedunculate form, and that of Notamia with the sessile or immersed variety.

To show the extent in which organs either avicularian or vibracular exist in the cheilostomatous Polyzoa, a list is subjoined of those genera and species contained in the present Catalogue, in which I have noticed the existence either of avicularia or vibracula or of both :

1. Species possessing avicularia.

Those marked with an asterisk * also have vibracula.

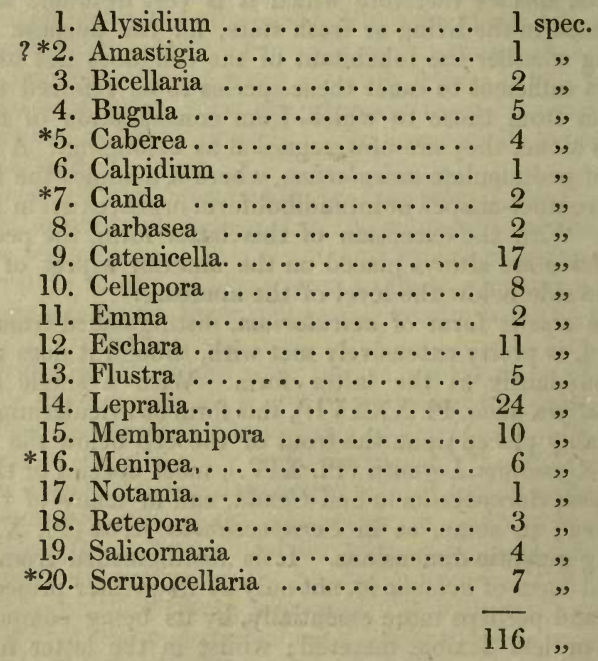

2. Species having vibracula only.

1. Cupularia............... 5 ,

2. Lunulites................ 4 ,

3. Selenaria ................. 1 ",

10 ,

from which it appears that of thirty-six genera, twenty include species armed in the one way or other; and that of 191 species, no less than 126 are furnished with avicularia or vibracula ;-circumstance in itself sufficient to demonstrate the importance of these organs in a systematic history of the Polyzoa. 


\section{LIST OF PLATES TO PART II.}

Plate

LXIX. Membranipora Lacroixii, p. 60.

LXX. Membranipora monostachys, p. 61.

LXXI. Membranipora pilosa, p. 56.

LXXII. Diachoris inermis, p. 54.

LXXIII. Figs. 1, 2, 3. Lepralia figularis, p. 80.

Figs. 4, 5. Membranipora coriacea, p. 57 .

Figs. 6, 7. Membranipora umbonata, p. 57.

LXXIV. Figs. 1, 2. Lepralia ciliata, p. 73.

Figs. 3-5. Lepralia variolosa, p. 75.

LXXV. Lepralia variolosa, p. 75.

LXXVI. Fig. 1. Lepralia nitida, p. 76 .

Figs. 2, 3. Lepralia spinifera, p. 69.

LXXVII. Fig. 1. Lepralia annulata, p. 76.

Fig. 2. Lepralia granifera, p. 83.

Figs. 3, 4, 5. Lepralia ciliata, p. 73.

LXXVIII. Lepralia pertusa, p. 80.

LXXIX. Figs. 1, 2. Lepralia pertusa, p. 80.

Fig. 3. Lepralia alata, p. 71 . 
Plate

LXXX. Figs. 1-4. Lepralia bispinosa, p. 77. Figs. 4-7. Lepralia spinifera, p. 69.

LXXXI. Figs. 1-5. Lepralia Brongniartii, p. 65. Figs. 6, 7. Lepralia spinifera, p. 69.

LXXXII. Figs. 1-3. Lepralia hyalina, p. 84 . Fig. 4. Lepralia Peachii, p. 77.

Figs. 5, 6. Lepralia ventricosa, p. 78.

LXXXIII. Figs. 1, 2. Lepralia pallasiana, p. 81 . Figs. 3, 4. Lepralia areolata, p. 82. Fig. 5. Lepralia ventricosa, p. 78. Fig. 6. Lepralia Gattyæ, p. 73.

LXXXIV. Figs. 1, 2, 3. Lepralia simplex, p. 82. Figs. 4, 5, 6. Membranipora Flemingii, p. 58.

LXXXV. Figs. 1, 2. Lepralia trispinosa, p. 70. Fig. 3. Lepralia melolontha, p. 78. Figs. 4, 5. Lepralia labiosa, p. 82.

LXXXVI. Fig. 1. Lepralia Landsborovii, p. 66. Figs. 2, 3. Lepralia innominata, p. 79.

LXXXVII. Figs. 1, 2. Lepralia violacea, p. 69. Figs. 3, 4. Lepralia verrucosa, p. 68. Figs. 5, 6, 7, 8. Lepralia Hyndmanni, p. 74.

LXXXVIII. Lepralia coccinea, p. 70.

LXXXIX. Figs. 1-3. Lepralia linearis, p. 71. Figs. 4, 5, 6. Lepralia auriculata, p. 67.

XC. Fig. 1. Lepralia reticulata, p. 66. Figs. 2-4. Lepralia personata, p. 74. Figs. 5, 6. Lepralia punctata, p. 79.

XCI. Figs. 1, 2. Lepralia spinifera, p. 69. Figs. 3, 4. Lepralia depressa, p. 75. Figs. 5, 6. Lepralia ventricosa, p. 78.

XCII. Figs. 1-3. Lepralia labrosa, p. 82. Fig. 4. Lepralia punctata, p. 79.

XCIII. Figs. 1, 2, 3, 4. Lepralia reticulata, p. 66 . Figs. 5, 6. Lepralia monoceros, p. 72. 
Plate

XCIV. Figs. 1, 2. Lepralia galeata, p. 66. Figs. 3, 4, 5. Lepralia bicristata, p. 72 .

Fig. 6. Lepralia verrueosa, p. 68.

XCV. Figs. 1, 2. Lepralia annularis, p. 85 . Figs. 3, 4, 5. Lepralia hyalina, p. 84 .

Figs. 6, 7. Lepralia granifera, p. 83.

XCVI. Figs. 1, 2. Lepralia Marionensis, p. 67.

Fig. 3. Lepralia punctata, p. 79.

Figs. 4, 5. Lepralia cucullata, p. 81.

XCVII. Lepralia Peachii, p. 77.

XCVIII. Lepralia trispinosa, p. 70.

XCIX. Lepralia concinna, p. 67.

C. Fig. 1. Membranipora stenostoma, p. 60 .

Fig. 2. Membranipora Rosselii, p. 59.

Fig. 3. Membranipora cervicornis, p. 60.

CI. Figs. 1, 2. Lepralia hyalina, p. 84.

Figs. 3, 4. Lepralia discreta, p. 85.

Figs. 5, 6. Lepralia margaritifera, p. 72.

CII. Fig. 1. Lepralia reticulata, p. 66.

Fig. 2. Lepralia trispinosa, p. 70.

Figs. 3, 4. Lepralia adpressa, p. 82.

CIII. Figs. 1-5. Lepralia Malusii, p. 83.

Fig. 6. Lepralia Lyallii, p. 75.

CIV. Fig. 1. Membranipora Lacroixii, p. 60.

Figs. 2, 3, 4. Membranipora Flemingii, p. 58.

Figs. 5, 6. Membranipora calpensis, p. 60.

CV. Figs. 1-3. Eschara platalea, p. 90 .

Figs. 4-6. Eschara urceolata, p. 90.

CVI. Figs. 1-3. Eschara lichenoides, p. 90.

Figs. 4-7. Eschara foliacea, p. 89.

CVII. Figs. 1-3. Eschara fuegensis, p. 90.

Figs. 4-6. Eschara decussata, p. 91.

Figs. 7-10. Eschara flabellaris, p. 91.

CVIII. Figs. 1-3. Eschara contorta, p. 89.

Fig. 4. Eschara platalea, p. 90.

Figs. 5-7. Eschara gracilis, p. 91. 
Plate

CIX. Figs. 1-3. Cellepora ramulosa, p. 87. Figs. 4-6. Cellepora Hassallii, p. 86. Fig. 7. Eschara cervicornis, p. 92.

CX. Fig. 1. Lepralia violacea, $\beta$. cruenta, p. 69. Fig. 2. Cellepora pumicosa, p. 86 .

CXI. Lunulites gibbosa, p. 100.

CXII. Lunulites capulus, p. 100.

CXIII. Figs. 1-3. Lunulites philippinensis, p. 101. Figs. 4-7. Lunulites cancellata, p. 101.

CXIV. Fig. 1. Cupularia guineensis, p. 98.

CXV. Cupularia Owenii, p. 99.

CXVI. Cupularia Lowei, p. 99.

CXVII. Selenaria maculata, p. 101.

CXVIII. Cupularia stellata, p. 99.

CXIX. Fig. 1. Eschara cervicornis, p. 92.

Fig. 2. Cellepora fusca, p. 88.

Fig. 3. Eschara gigantea, p. 91.

CXX. Figs. 1, 2. Cellepora bispinata, p. 87.

Figs. 3, 4. Cellepora mamillata, p. 87.

Fig. 6. Cellepora fusca, p. 88.

CXXI. Figs. 1, 2. Retepora phœnicea, p. 94. Figs. 3-8. Retepora cellulosa, p. 93.

CXXII. Cellepora Skenei, p. 88.

CXXIII. Figs. 1-5. Retepora beaniana, p. 94. Figs. 5, 6. Retepora cellulosa, p. 93.

CXXIV. Cupularia pyriformis, p. 100. 
The following Figures, contained in Plates given in PART I., relate to species described in the present PART.

Plate

LXI. Fig. 1. Membranipora lineata, p. 58. Fig. 2. Membranipora Flemingii, p. 58.

LXV. Fig. 2. Vincularia ornata, p. 96. Fig. 3. Membranipora cyclops, p. 61. Fig. 4. Membranipora magnilabris, p. 62. Fig. 5. Membranipora galeata, p. 62 . Fig. 6. Membranipora Rozieri, p. 59.

LXVIII. Fig. 2. Membranipora membranacea, p. 56. 


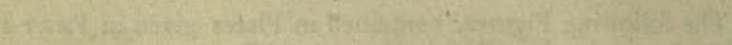

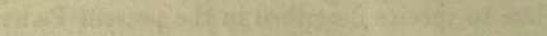

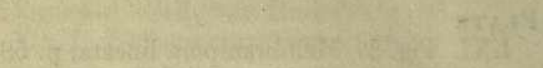
S4.

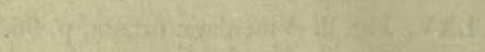

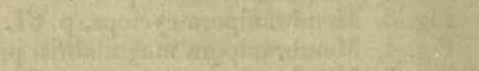

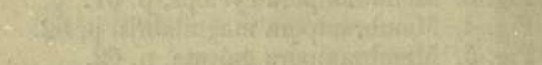

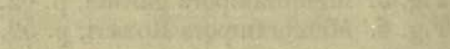

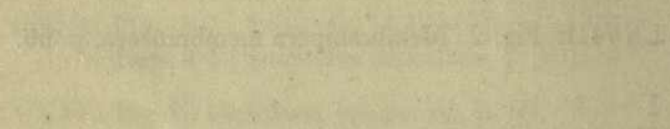

, 


\section{N D E X.}

Acamarchis, 24, 26. aculeata (Farc.), 33. adpressa (Lepr.), 82. Atea, 30. alata (Lepr.), 71. alcicornis (Millep.), 92. Alysidium, 13. Amastigia, 40. Amphiblestrum, 56. amphora (Catenic.), 8. Anguina (Cell.), 31 .
- (Cellul.), 31. (Falc.), 31. (Sert.), 31.

Anguinaria, 30. angustiloba (Flustra), 45. annularis (Eschara), 84.

- (Lepr.), 84. annulata (Cellep.), 77. - (Lepr.), 76. Annulipora, 56. ansata (Lepr.), 71. appensa (Lepr.), 71. arachnoides (Canda), 26. arenacea (Lepr.), 79. areolata (Lepr.), 82. armata (Carb.), 50. assimilis (Lepr.), 65. auriculata (Lepr.), 67. aurita (Catenic.), 8. australis (Beania), 32. avicularia (Bugula), 45. (Cellul.), 45. (Crisia), 45. avicularia (Flustra), 44.

- (Sert.), 45. avicularis (Cellul.), 45.

Ballii (Lepr.), 71.

Beania, 32.

beaniana (Retep.), 94 .

Berenicea, 63.

Bertholletii, 24.

Bicellaria, 41.

Bicellariadæ, 41.

bicornis (Salic.), 17.

bicristata (Lepr.), 72.

bicuspis (Catenic.), 7 .

biforis (Herentia), 83.

(Lepr.), 83.

bimucronata (Cellep.), 77, 86.

- (Eschara), 77, 86.

Bi-multiserialaria, 15, 32.

bispinata (Cellep.), 87.

bispinosa (Discop.), 77.

- (Lepr.), 77.

bombycina (Carb.), 52.

Boryi (Crisia), 38.

Brongniartii (Cellep.), 65. (Lepr.), 65.

Bugula, 19, 43.

bullata (Flustra), 86.

bursaria (Cell.), 36.

- (Epist.), 36.

- (Not.), 36.

- (Sert.), 36.

Caberea, 37. 
Hookeri (Bicell.), 39.

- (Cab.), 39. (Cellul.), 39.

Hornwrack, Broad-leaved, 48. -, Narrow-leaved, 48. hyalina (Berenicea), 84 .

- (Cellep.), 84.

- (Cellepor.), 84. (Lepr.), 84.

Hyndmanni (Her.), 74. - (Lepr.), 74.

immersa (Berenicea), 77.

- (Lepr.), 77.

impressa (Flustra), 84. indivisa (Carb.), 53. inermis (Diach.), 54. innominata (Lepr.), 79. insignis (Lepr.), 73.

Isis, 16.

Jacotini (Lepr.), 65. Johnstoni (Lepr.), 68. Johnstoniæ (Hal.), 43. Jolloisii (Acamarchis), 26.

labiosa (Lepr.), 82. labrosa (Lepr.), 82. Lacroixii (Flustra), 61. - (Membr.), 60. lævis (Cellep.), 87. Lafontii (Alysid.), 14. - (Euc.), 14. lamellosa (Cellep.), 89. lanceolata (Hippothoa), 30. Landsborovii (Lepr.), 66. lata (Cab.), 39. Lepralia, 63.

lichenoides (Eschara), 90. ligulata (Ætea), 31. linearis (Herentia), 71. (Lepr.), 71.

lineata (Callopora), 58. (Flustra), 57, 58. (Membr.), 58.

lorica (Catenic.), 6. Loricaria, 34.

loricata (Eucrat.), 29. - (Gemell.), 34. _ (Sert.), 34.
Loricula, 34. loriculata (Crisia), 34 . - (Gemell.), 35.

- (Gemic.), 34.

- (Not.), 34.

Lowei (Cupul.), 99.

- (Lunul.), 99.

Lunulites, 100.

Lyallii (Lepr.), 75.

Macandrei (Scrup.), 24. Macry (Cellep.), 83. maculata (Lunul.), 101. - (Selen.), 101. magellanica (Diach.), 54. magnilabris (Membr.), 62. Malusii (Lepr.), 83. malvinensis (Salic.), 18. mamillata (Cellep.), 87. Mangnevillana (Cellep.), 81 . margaritacea (Catenic.), 9. margaritifera (Lepr.), 72. marginata (Salic.), 19. marionensis (Lepr.), 67. melolontha (Lepr.), 78 . membranacea (Flustra), 56. - (Membr.), 56.

membranaceum (Amphibl.), 59. Membranipora, 56.

Membraniporidæ, 55 .

Menipea, 20.

Micropora, 56. millepora (Eschara), 57. mirabilis (Beania), 32. mollis (Sert.), 31. monoceros (Lepr.), 72. monostachys, 61 . monotrypa (Cellul.), 20. Montferrandii (Flustra), 67. multiseriata (Menip.), 22. Murravana (Bugula), 46. - (Flustra), 46.

Nellia, 18. neritina (Acam.), 44.

- (Bugula), 20, 44.

- (Cell.), 44, 46.

- (Cellul.), 20, 44.

- (Crisia), 14.

- (Sert.), 44. 
nitida (Berenicea), 76 .

$$
\text { - (Cellep.), } 76 .
$$

Notamia, $34,36$.

nuda (Amastig.), 40.

$$
\text { - (Cab.), } 40 .
$$

octodon (Flustra), 49. oculata (Nellia), 18. ornata (Cellul.), 20. (Vincular.), 96. ornatum (Calp.), 15. ovalis (Lepr.), 76. ovoidea (Carb.), 52. (Cellep.), 84. Owenii (Cupul.), 99. (Lunul.), 99.

pallasiana (Cellep.), 81. - (Eschara), 81. (Lepr.), 81.

palmata (Cellep.), 88. papyracea (Carb.), 50.

$$
\begin{aligned}
& \text { (Chartella), } 48 . \\
& \text { (Flustra), } 48 . \\
& \text { papyrea (Carb.), } 50 . \\
& \text { (Eschara), } 50 .
\end{aligned}
$$

parasiticum (Alysid.), 14. patagonica (Menip.), 22.

Peachii (Cellul.), 20.

- (Flustra), 59, 61 .

- (Lepr.), 77. (Membr.), 61.

pectinata (Lepr.), 79. pedilostoma (Lepr.), 61, 81 . perforata (Catenic.), 10. perlacea (Cellep.), 80. (Escharina), 80. personata (Cellep.), 84 .

- (Escharina), 84. (Lepr.), 74.

pertusa (Cellep.), 80 . - (Escharina), 80.

- (Lepr.), 80. philippinensis (Lunul.), 101. phœnicea (Retep.), 94. pilosa (Annulipora), 57. (Eschara), 56. pisciformis (Carb.), 50. plagiostoma (Catenic.), 8. platalea (Eschara), 90.

plumosa (Bicell.), 45, 46.

Porella, 63.

pumicosa (Cellep.), 86, 87 .

punctata (Lepr.), 79, 80 . (Salic.), 17.

pyriformis, 52, 100.

ramulosa (Cellep.), 87.

repens (Sert.), 26.

reptans (Bicell.), 26, 27.

- (Crisia), 27.

- (Scrup.), 27.

- (Scrupoc.), 27.

- (Sert.), 26.

Retepora, 93.

reticula (Millep.), 93.

reticulata (Frond.), 93.

- (Lepr.), 66, 68. reticulum (Conop.), 61 . ringens (Catenic.), 10. Rosselii (Flustra), 59. - (Membr.), 59.

Rozieri (Flustra), 59. - (Membr.), 59.

rudis (Cab.), 38.

Salicornaria, 16.

Salicornariadæ, 15.

Salicornariana, 15.

Salicorniaires, 17.

Salicornoides (Cell.), 17.

Savartii (Flustra), 61.

Savignyi (Catenic.), 10.

Scruparia, 28.

Scrupariadæ, 28.

scrupea (Scrup.), 24.

Scrupocellaria, 23.

scruposa (Bicell.), 25.

- (Cell.), 25.

- (Cellul.), 25.

- (Crisia), 25.

- (Scrup.), 25.

- (Scrupoc.), 25. (Sert.), 25.

securifrons (Chartella), 49.

- (Eschara), 49.

Selbia, 37.

Selenaria, 101.

Selenariadæ, 97. 
simplex (Didy.), 35 .

- (Lepr.), 82. (Nellia), 19.

sinuosa (Salic.), 17.

Siphonella, 95.

Skenei (Cellep.), 88.

_- (Millep.), 88. spathulosa (Farc.), 17. spatulata (Anguinaria), 31. spicata (Dimet.), 35. spinifera (Flustra), 58. - (Lepr.), 69. spinosa (Cellep.), 86. spiralis (Flabell.), 46.

- (Sert.), 46.

Spongites, 85.

stellata (Cupul.), 99. stenostoma (Membr.), 60.

taurina (Catenic.), 12. telacea (Flustra), 56. tenella (Cell.), 17. - (Millep.), 91. tenuirostris (Salic.), 17. tenuis (Lepr.), 65. Terebripora, 29. ternata (Cellul.), 21.

- (Crisia), 21.

- (Menip.), 21.

- (Sert.), 21.

- (Tric.), 21.

Tricellaria, 20. tricellata (Enma), 28. tridentata (Acamar.), 46. - - (Lepr.), 71.

triseriata (Menip.), 22. trispinosa (Berenicea), 70.

- (Disc.), 70. (Lepr.), 70.

truncata (Ætea), 31. (Flustra), 48, 49.

tuba (Bicell.), 42.

tuberculata (Flustra), 58.

umbonata (Catenic.), 11.

- (Membr.), 57.

Unicellaria, 29.

unicornis (Escharina), 69.

- (Flustra), 58.

- (Lepr.), 69.

- (Membr.), 58.

urceolata (Eschara), 90.

variolosa (Escharella), 76.

- (Lepr.), 70, 75.

ventricosa (Catenic.), 7. .

- - (Lepr.), 78.

verrucaria (Madrepora), 86. verrucosa (Cellep.), 68, 86 .

- (Disc.), 68.

- (Lepr.), 68. (Tubipora), 86.

vesiculosa (Cell.), 9.

vibicata (Retep.), 94.

Vincularia, 96.

Vinculariadæ, 95.

violacea (Escharella), 69.

- (Lepr.), 69.

vitrina (Cellep.), 87.

vulgaris (Escharina), 73.

zelanica (Selbia), 38. 


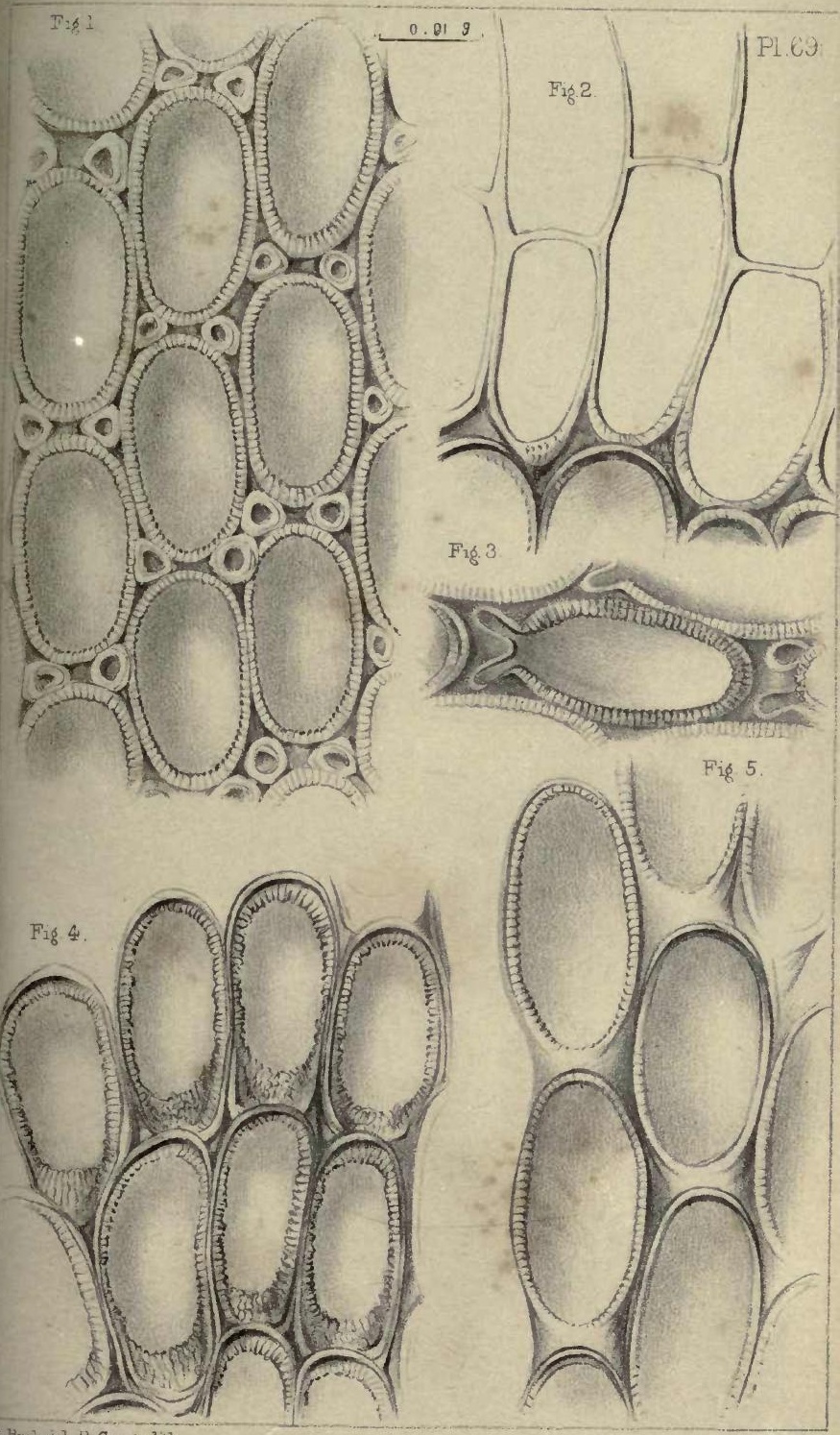

G Buar, del. B. George, lith. 


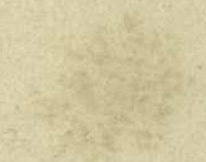




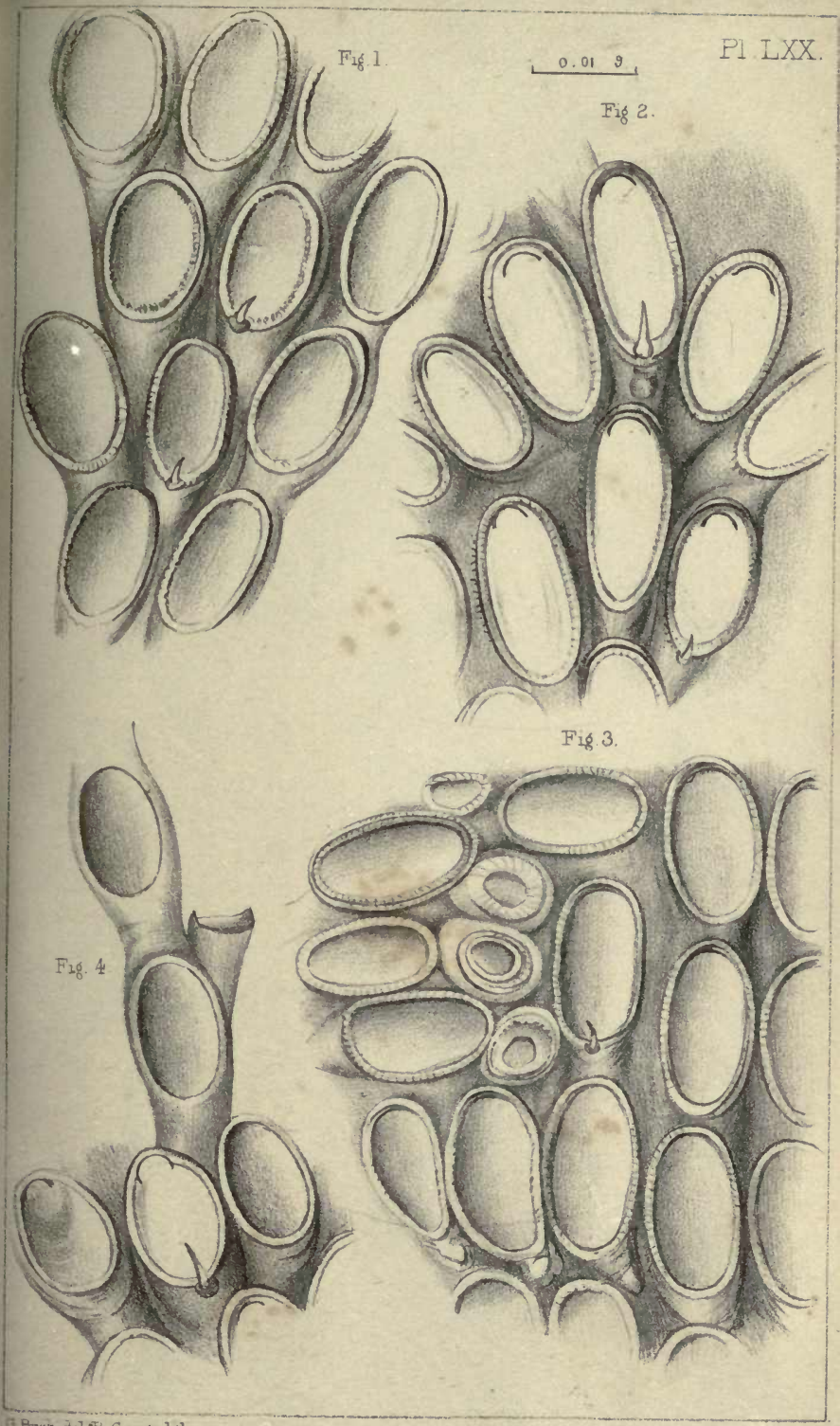




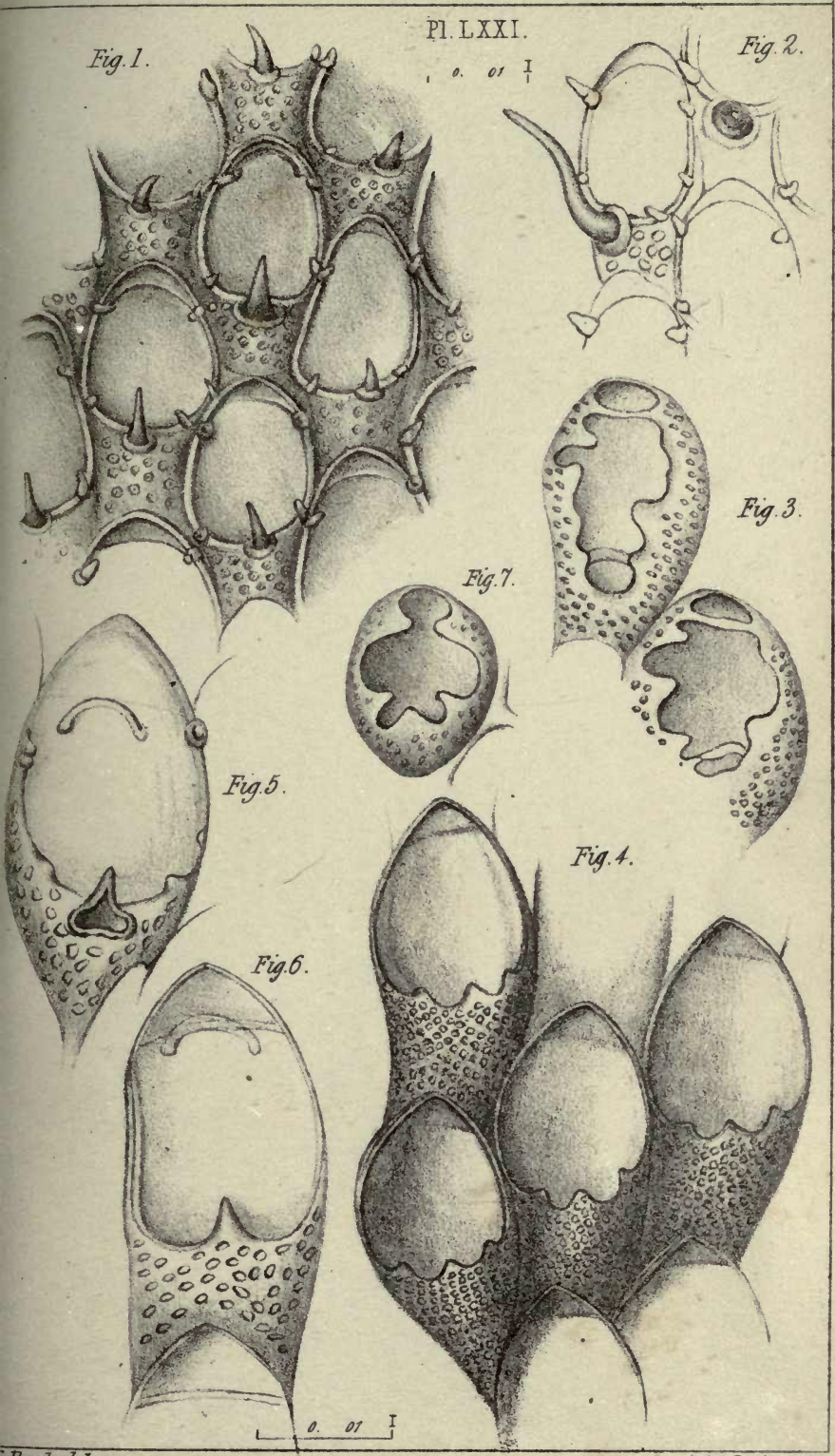

Busk det. 


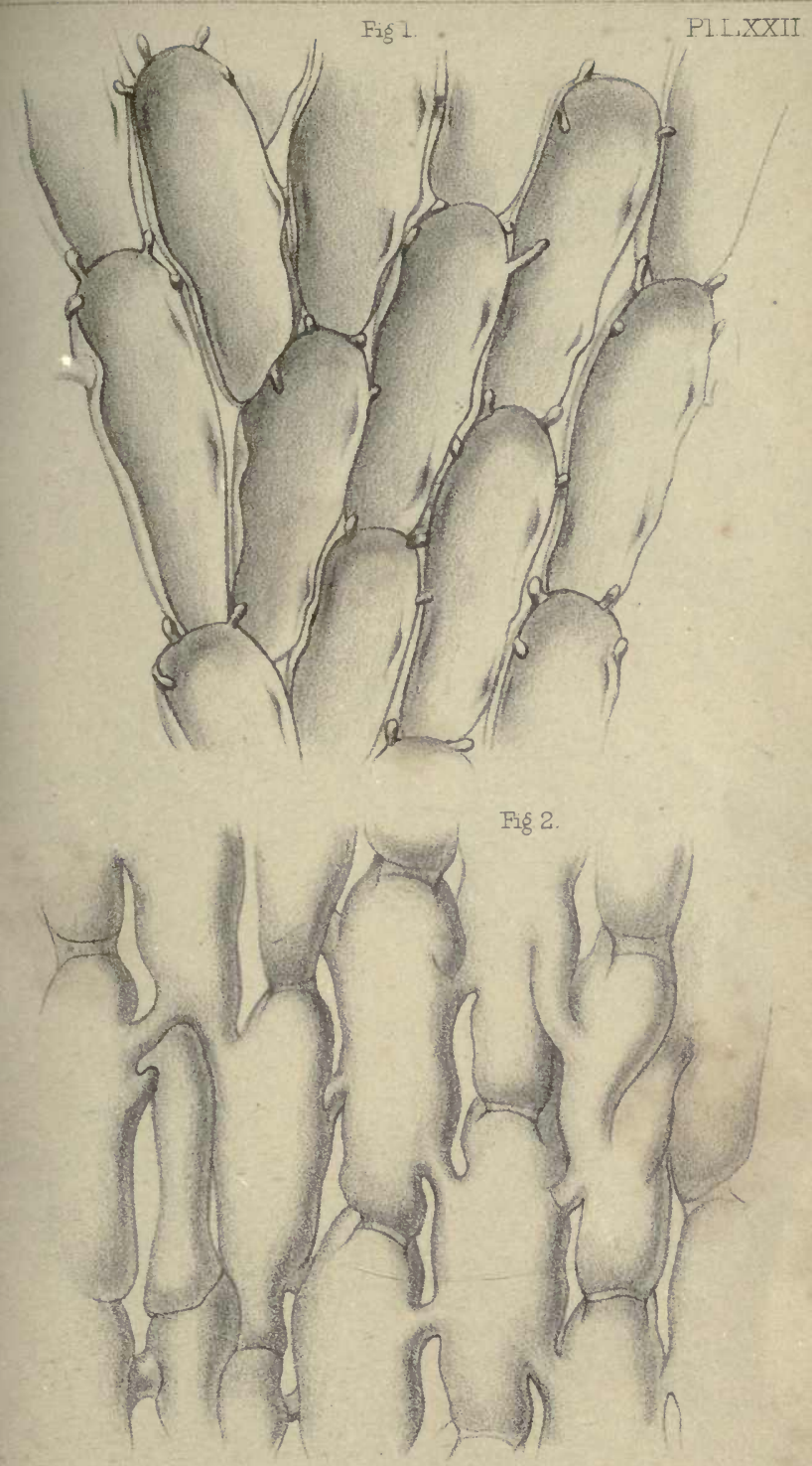

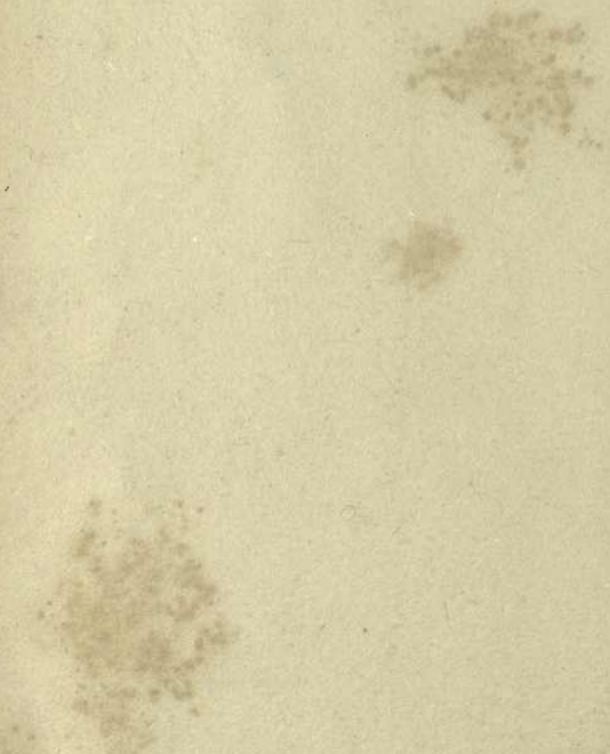

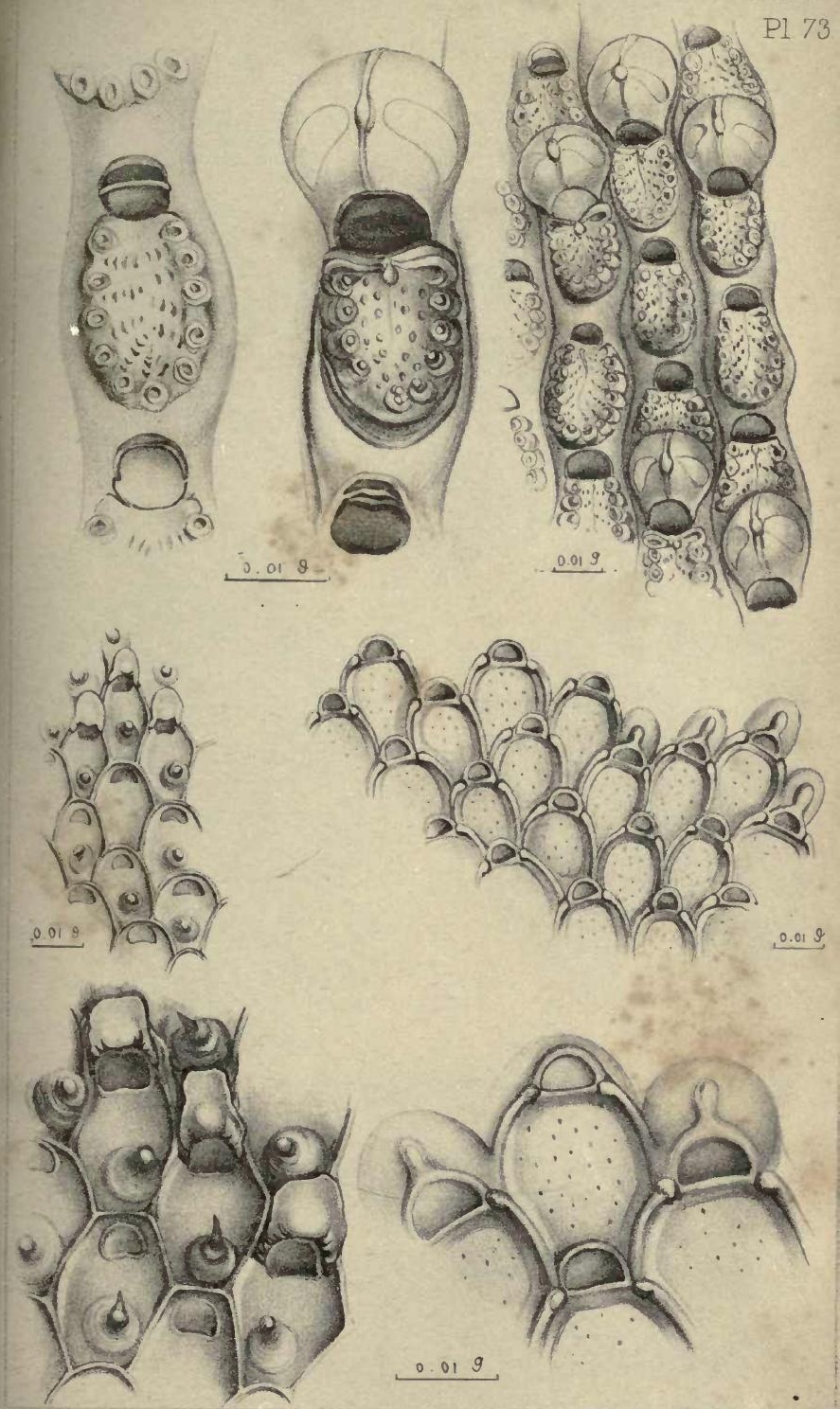

G13ukk, del B Geargo, Lth 


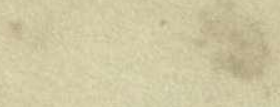

$$
\begin{aligned}
& \frac{13}{4 x^{2}} \\
& \frac{13}{4 x^{2}}
\end{aligned}
$$

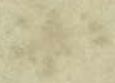

$$
\begin{aligned}
& \text {. } \\
& 4
\end{aligned}
$$

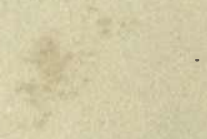

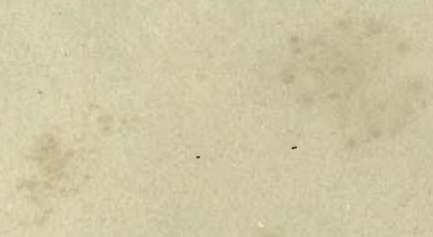

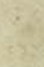

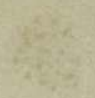

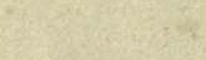

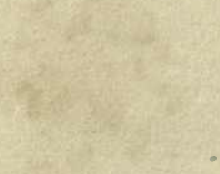

$x^{2}+3$

.

(3) $=38$

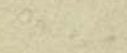




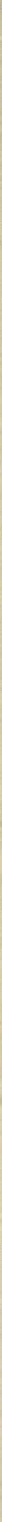




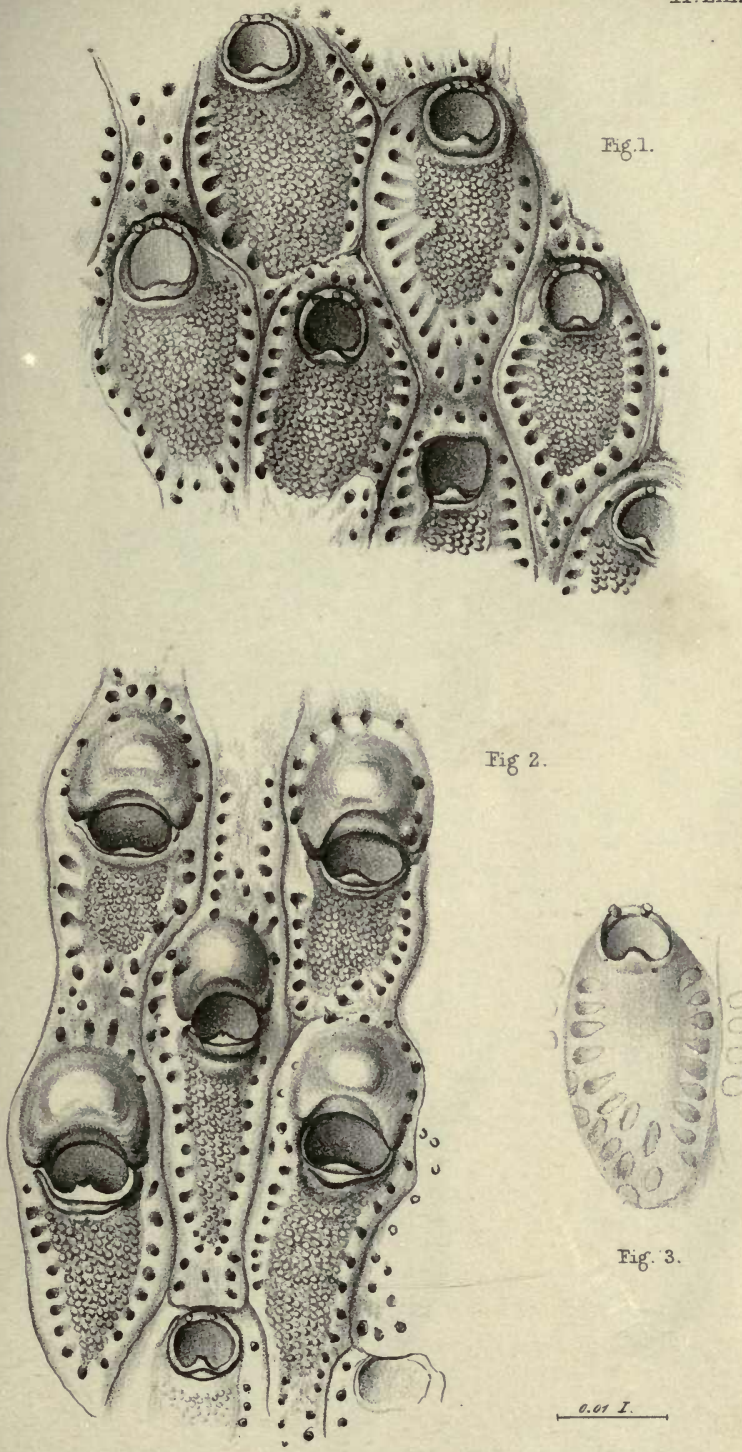



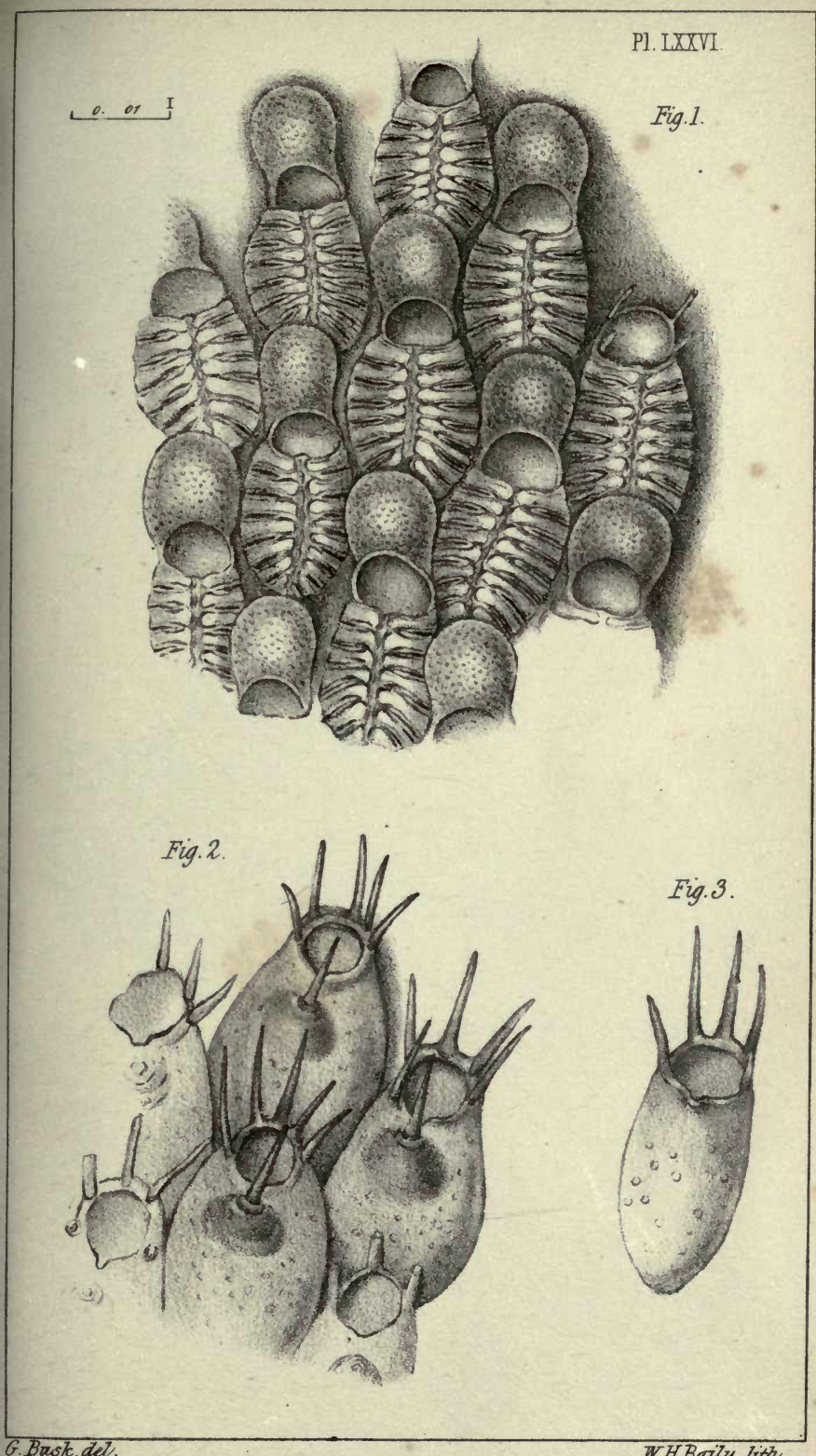





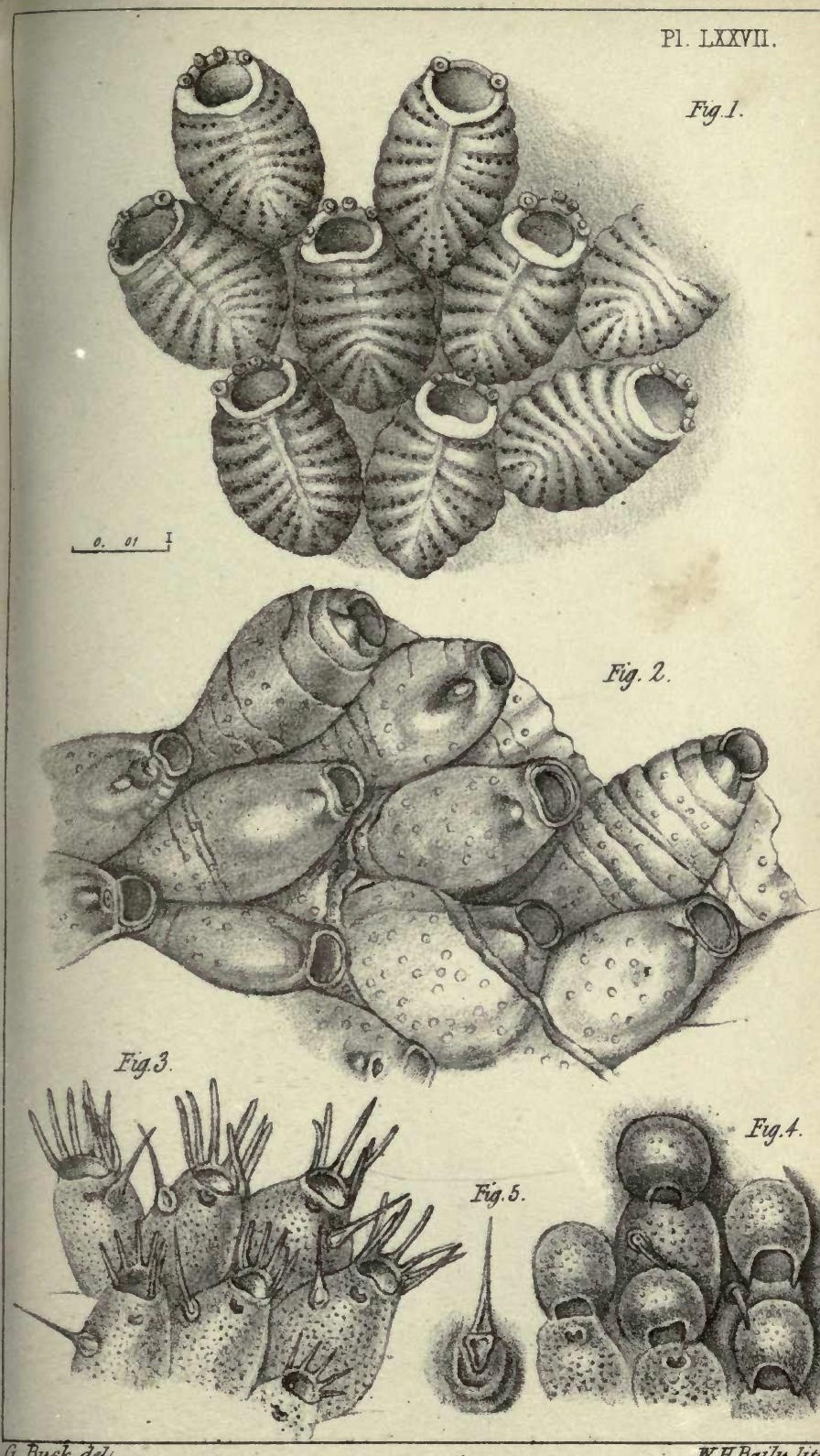



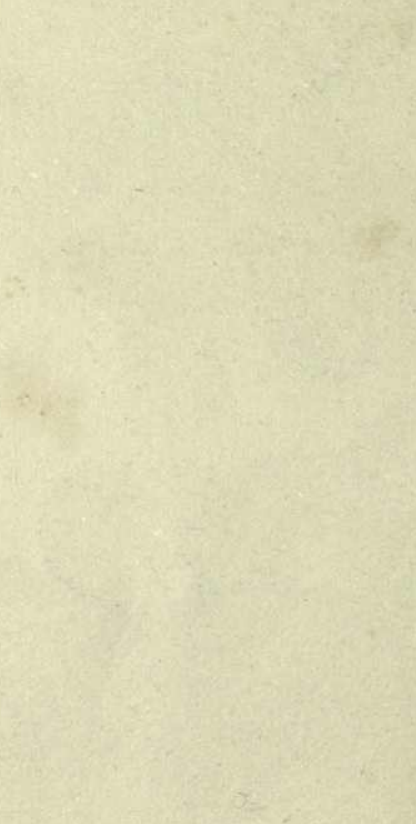


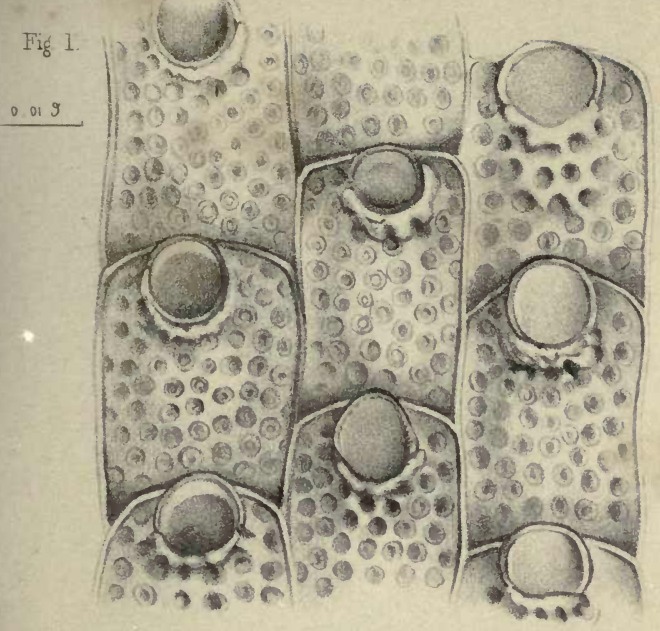

PI. LXXVIII

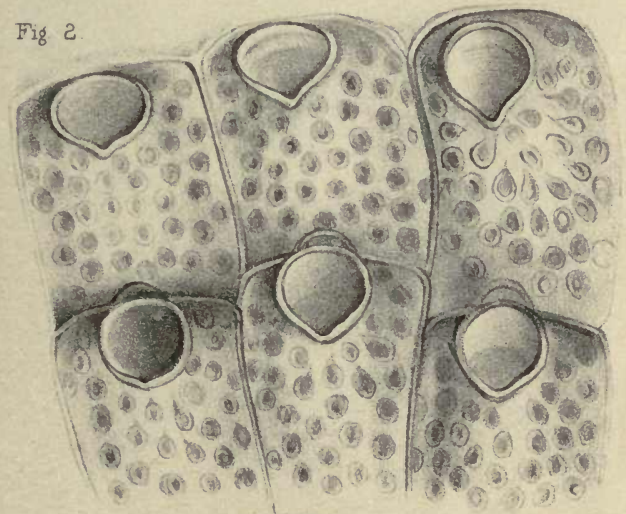

Fis 3.

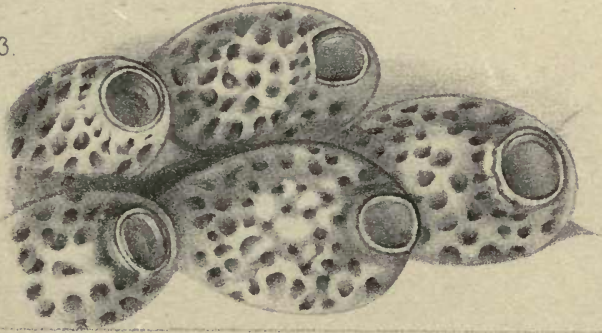





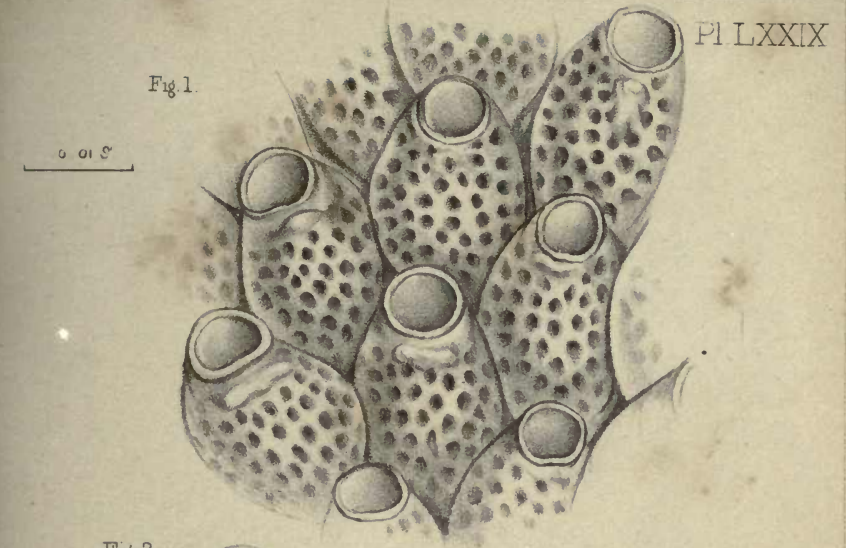

Fig 2
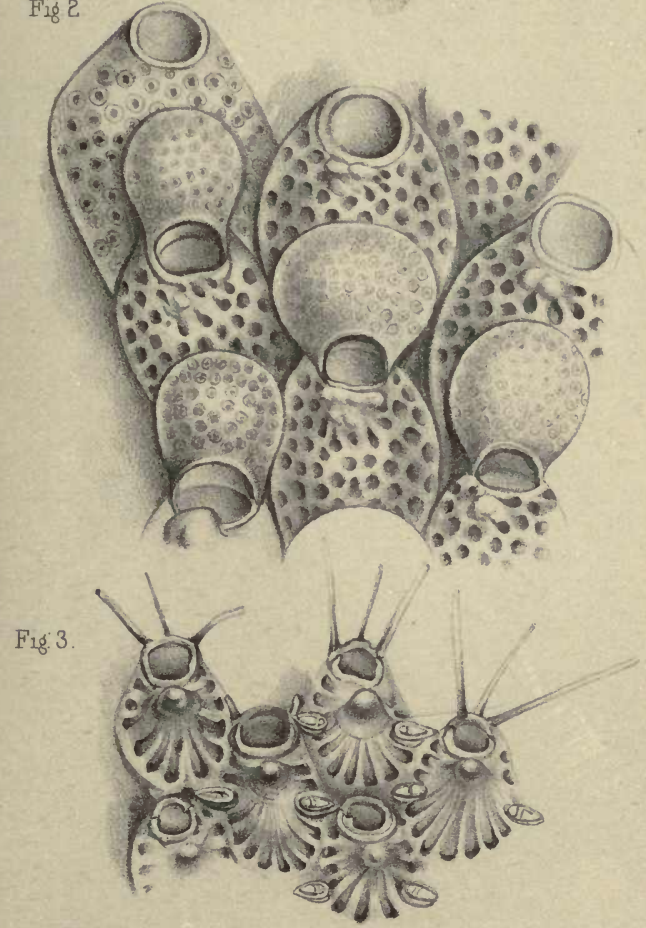


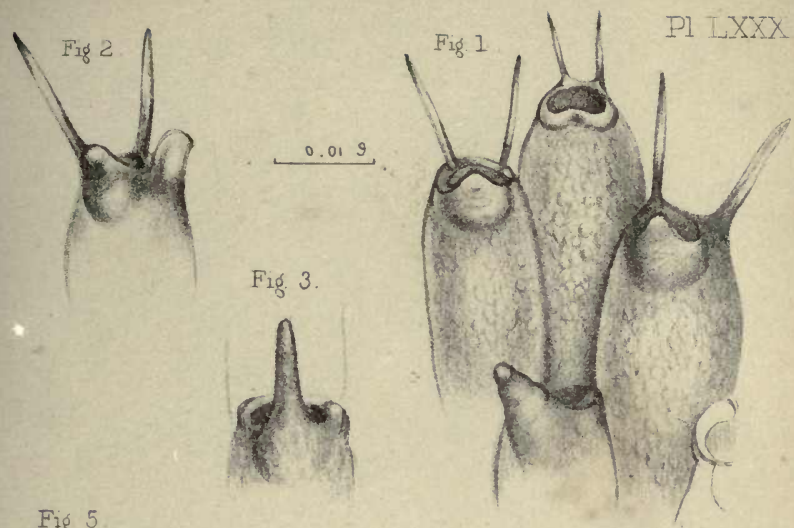

Fig 5
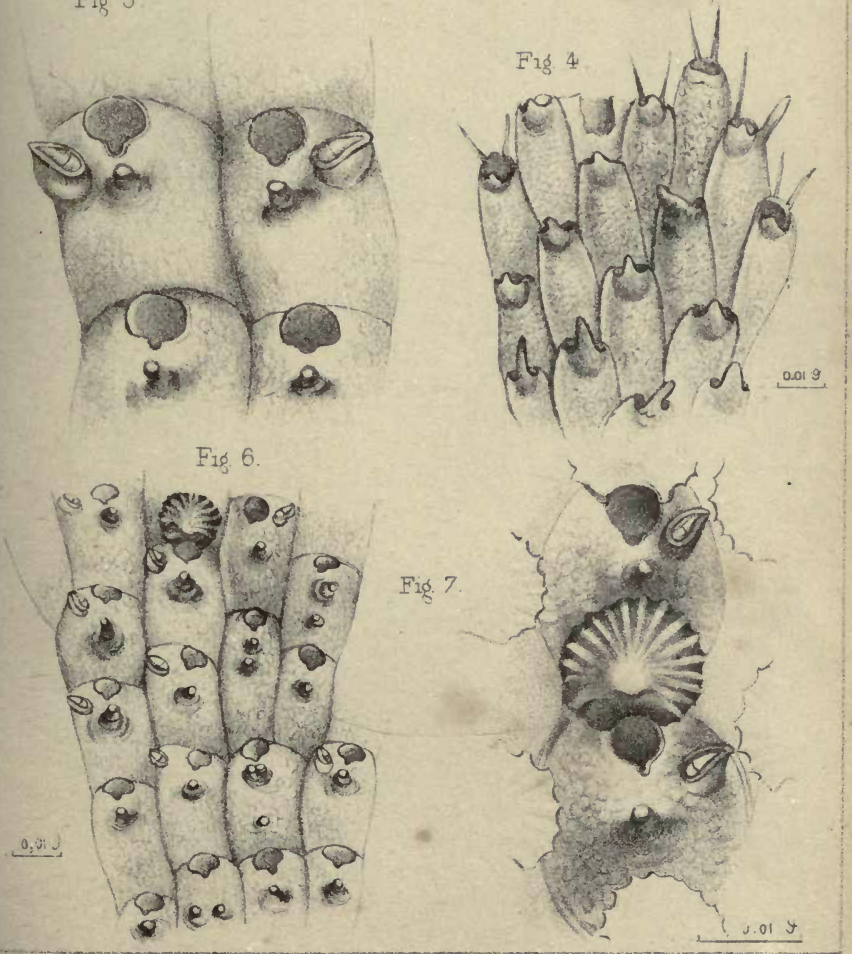



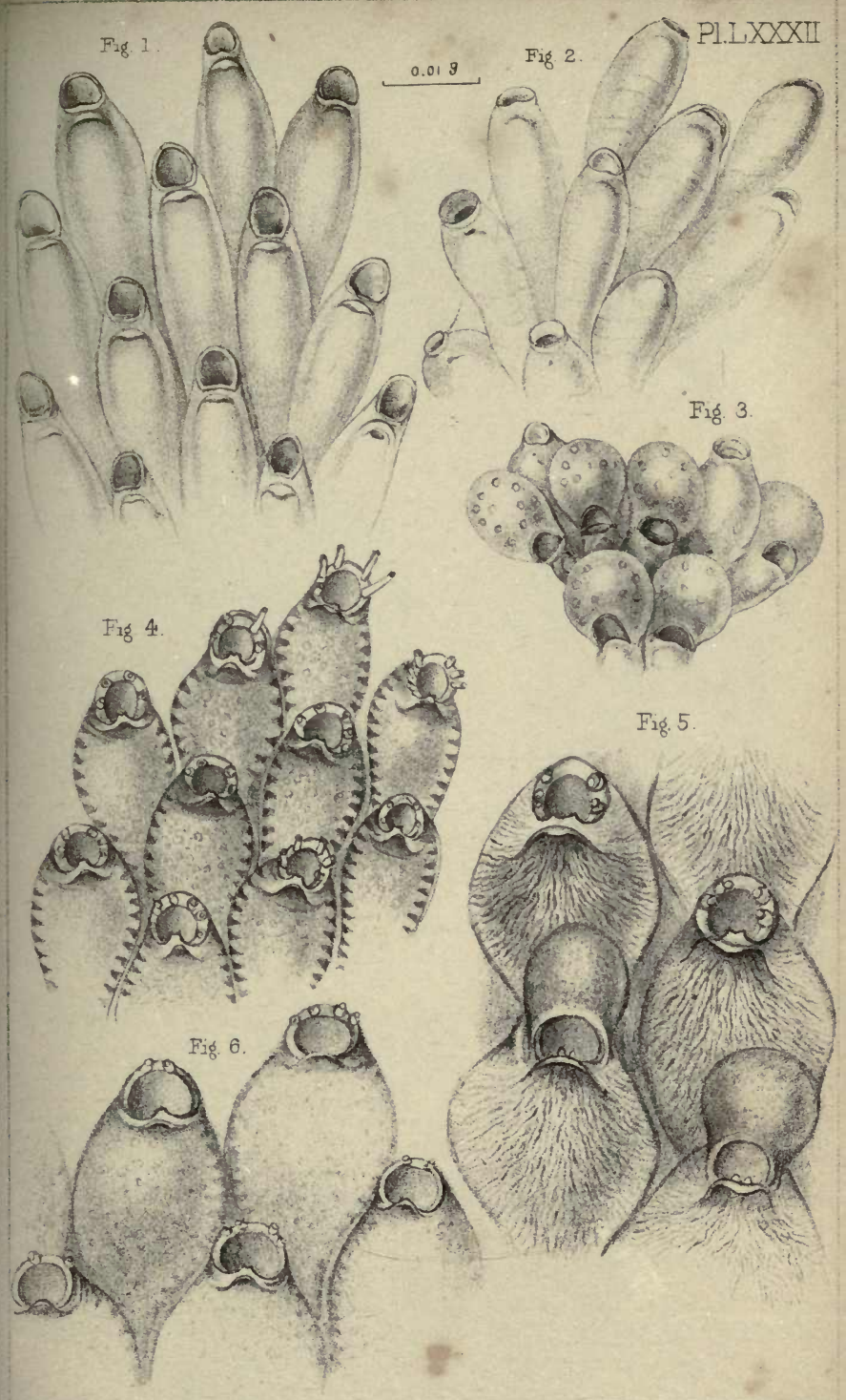




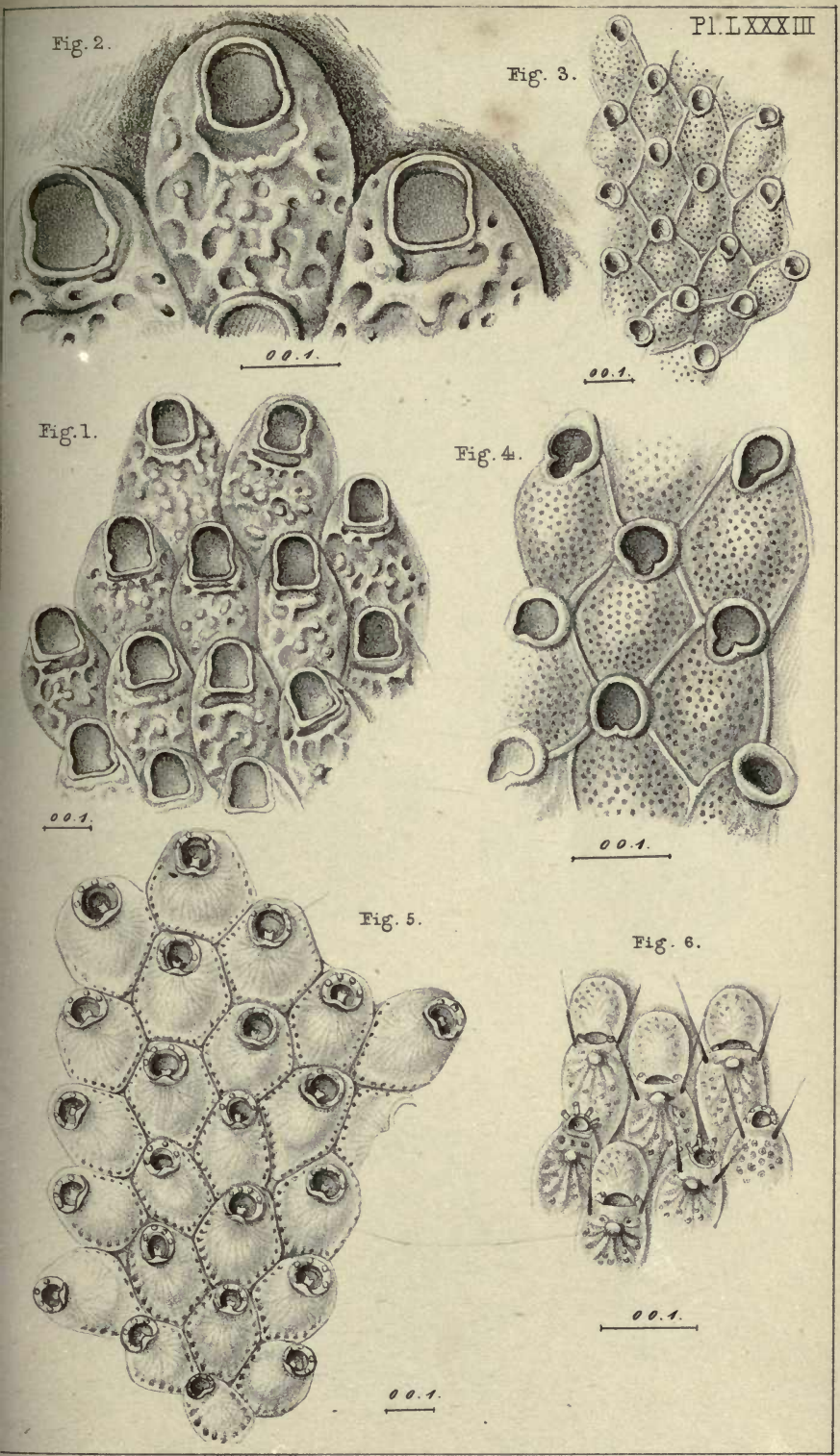


xinat

34:
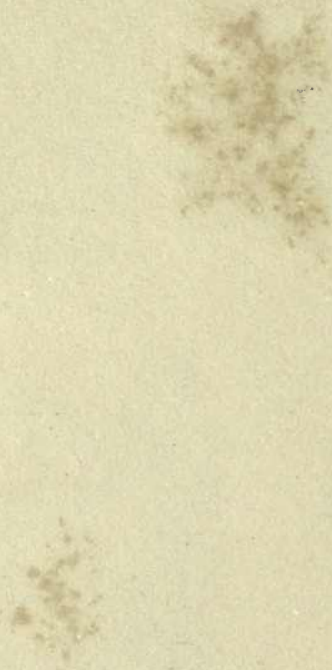


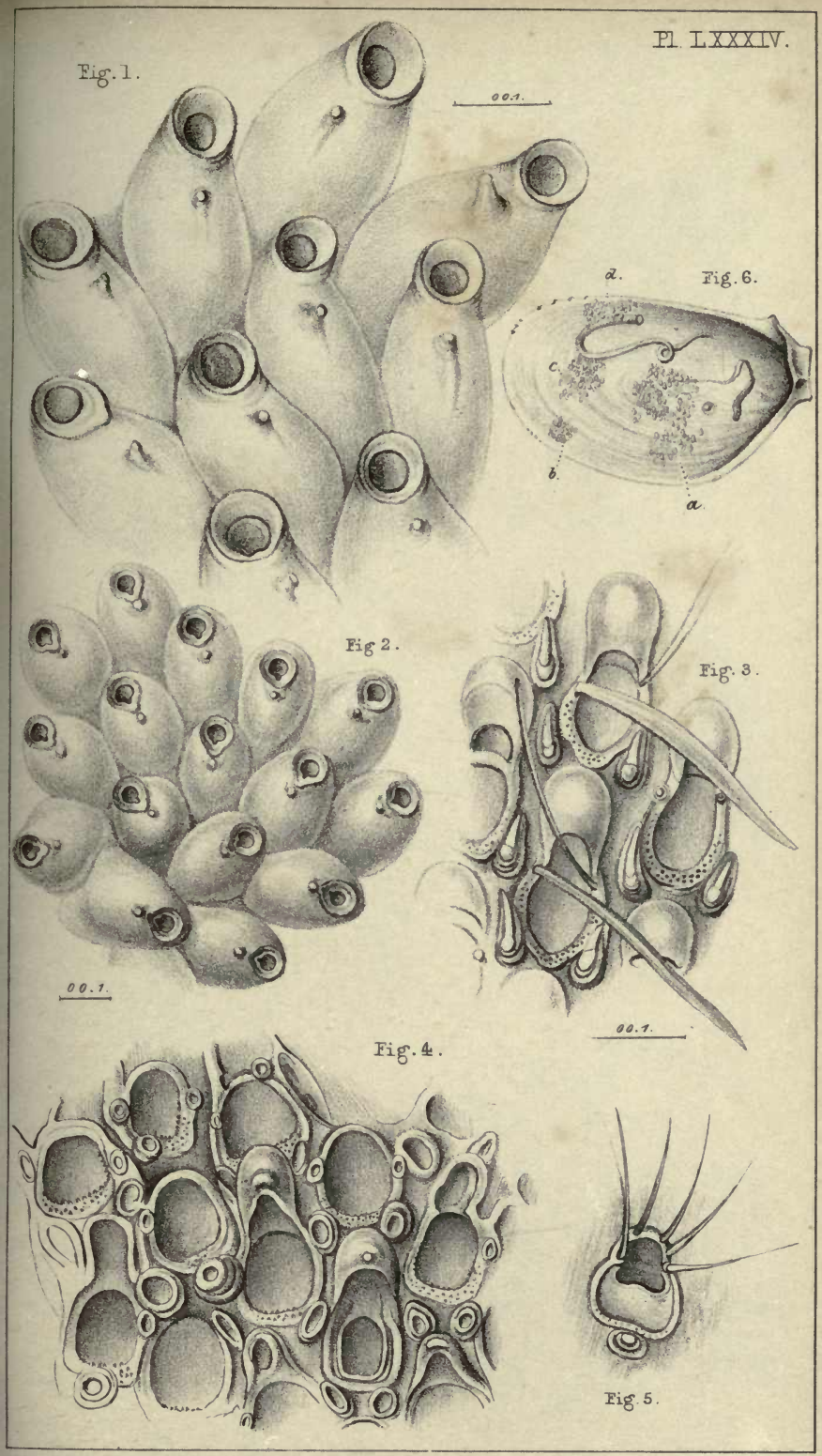




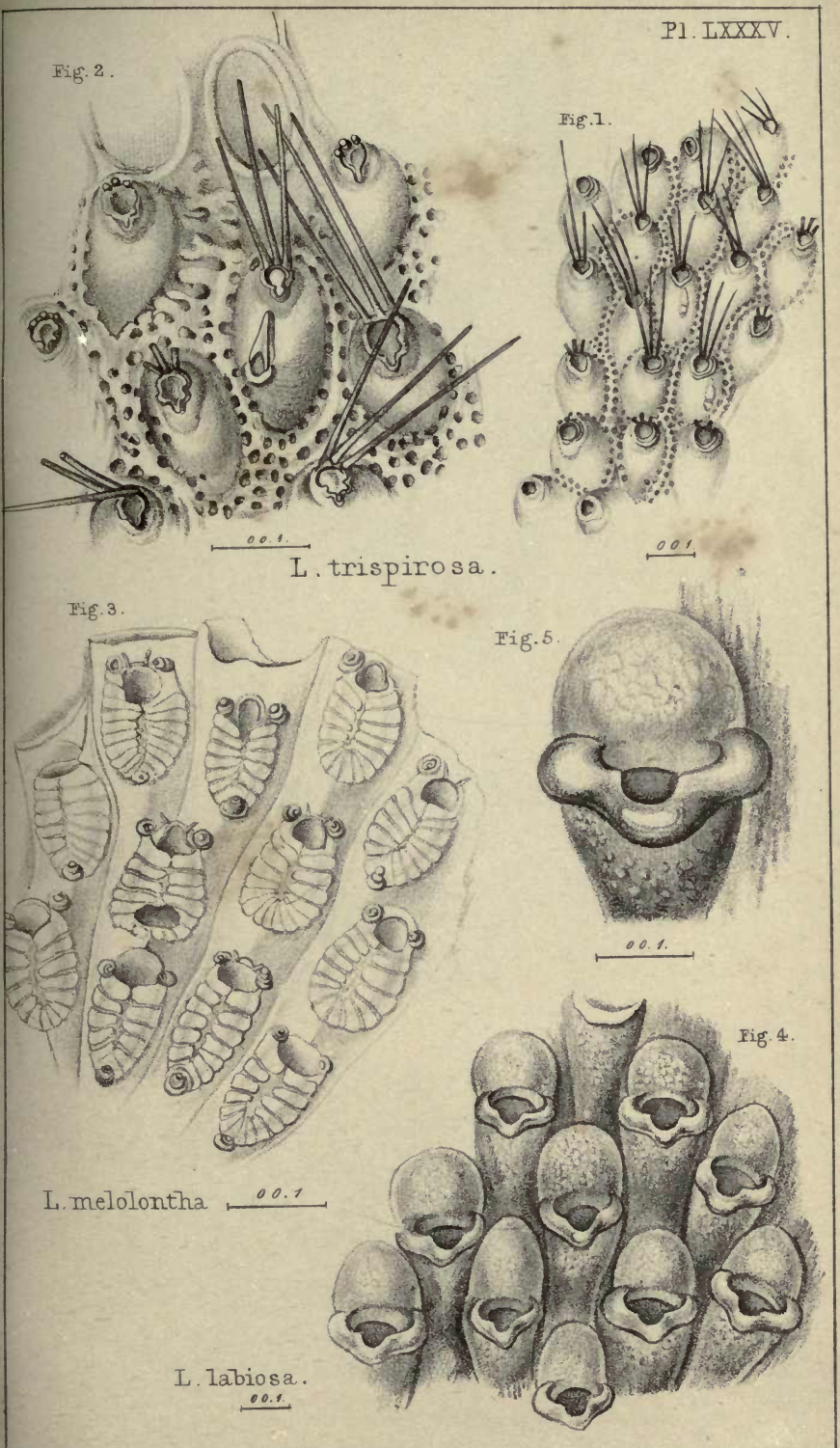

G. Buske del, Achilles, Jith. 


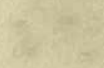




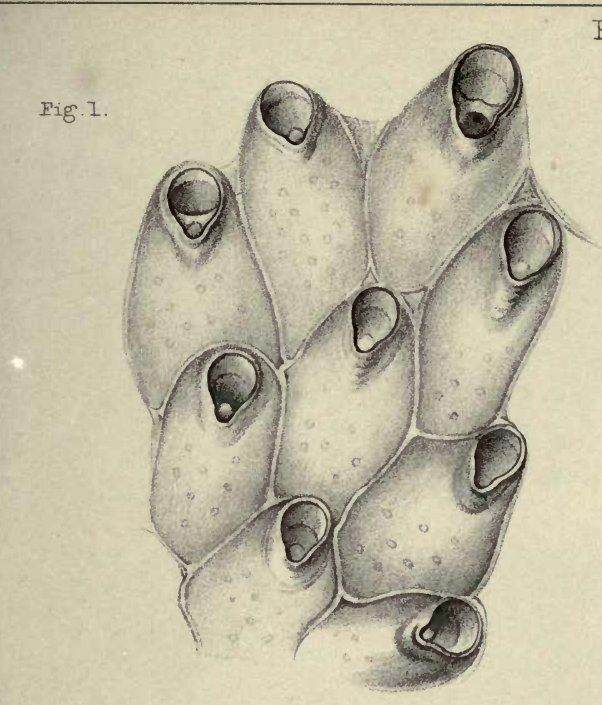

Pl.LXXXVI.

Fig. 2 .
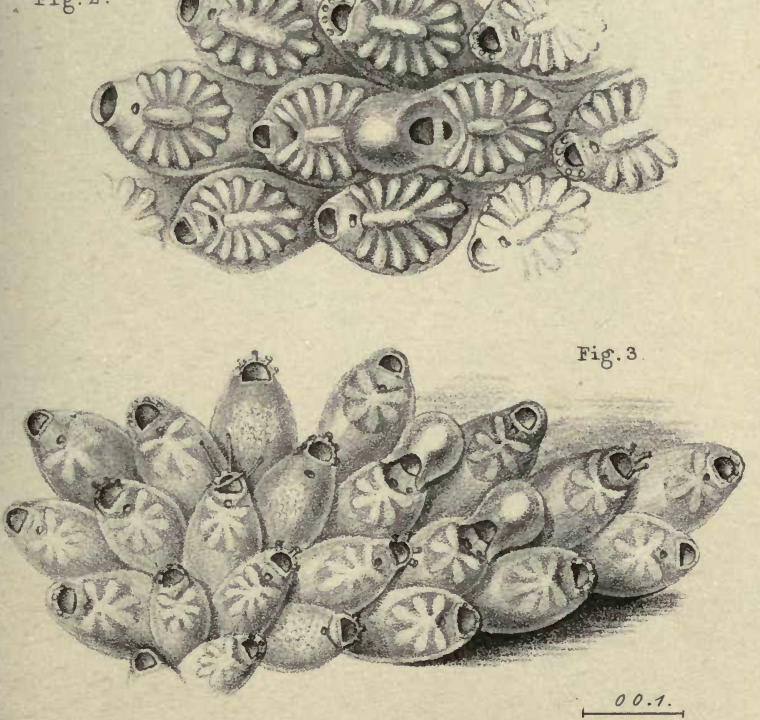

PI. IXXXVII.
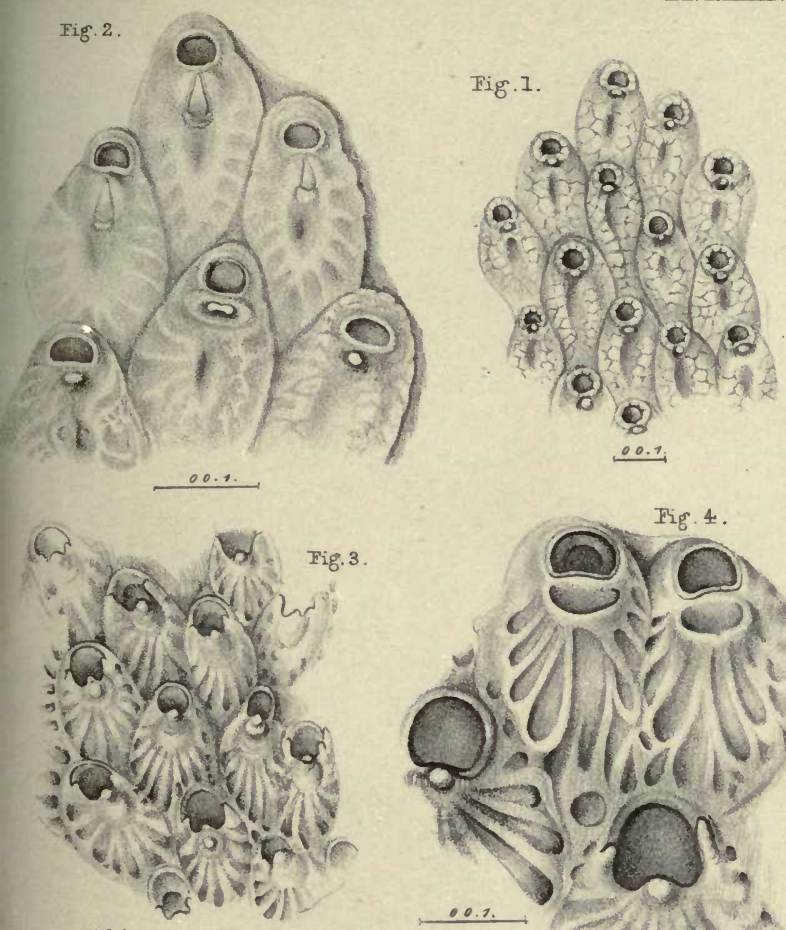


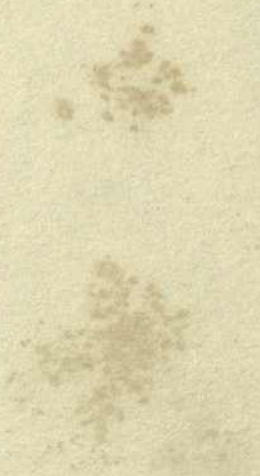


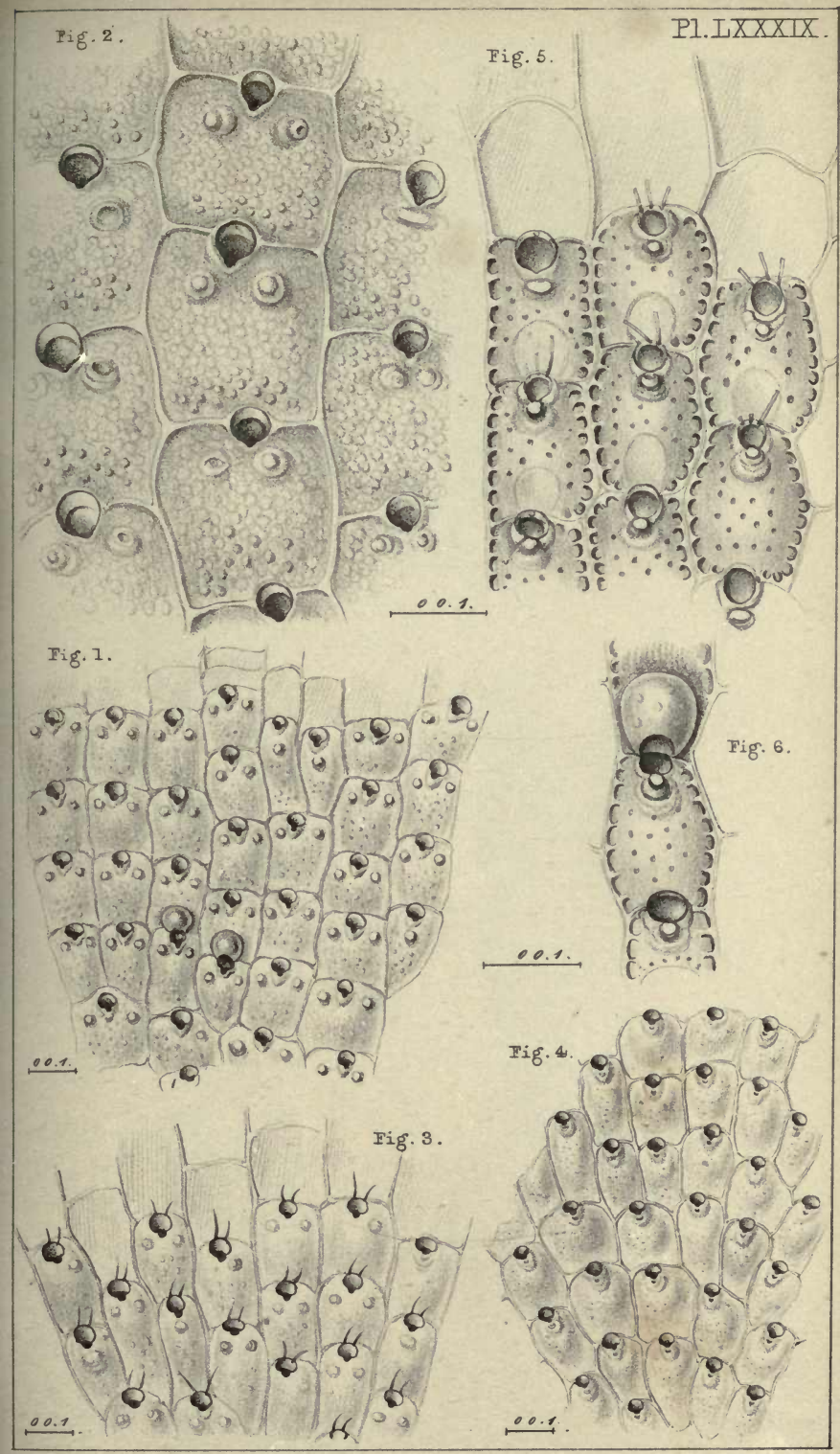





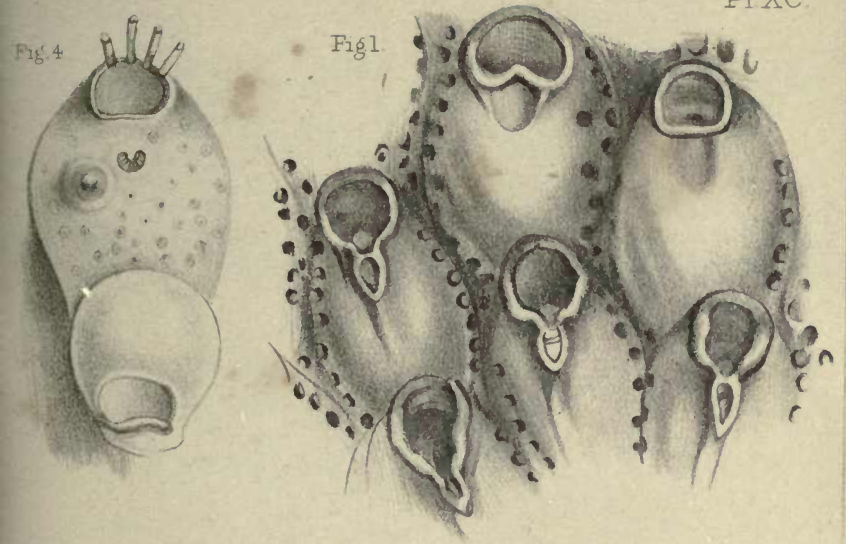

PI XC.
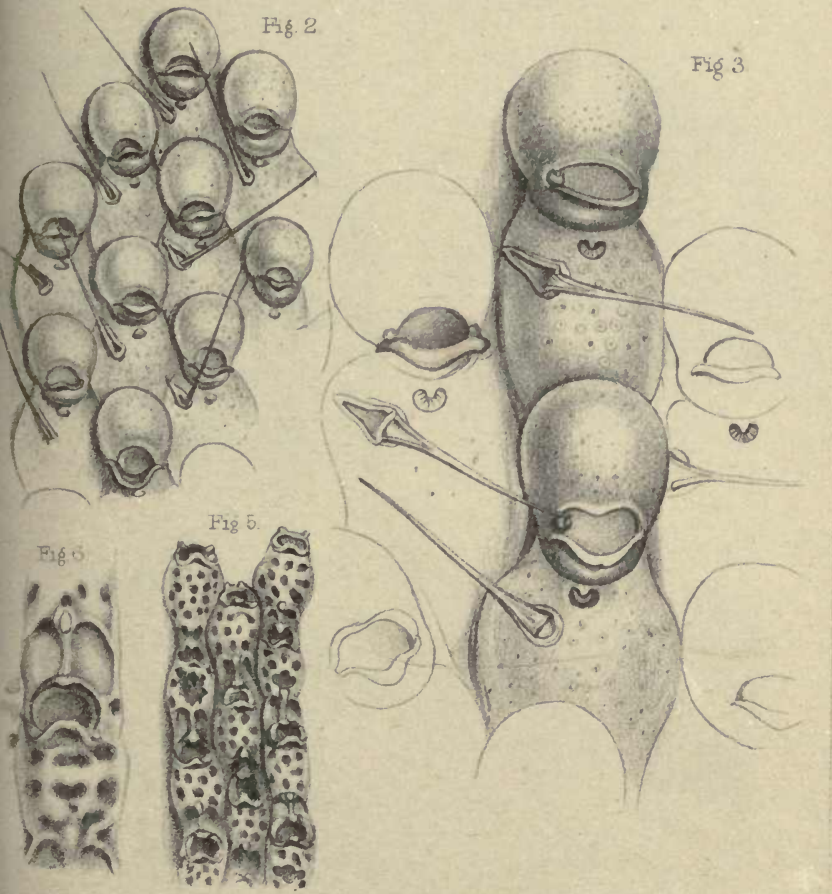




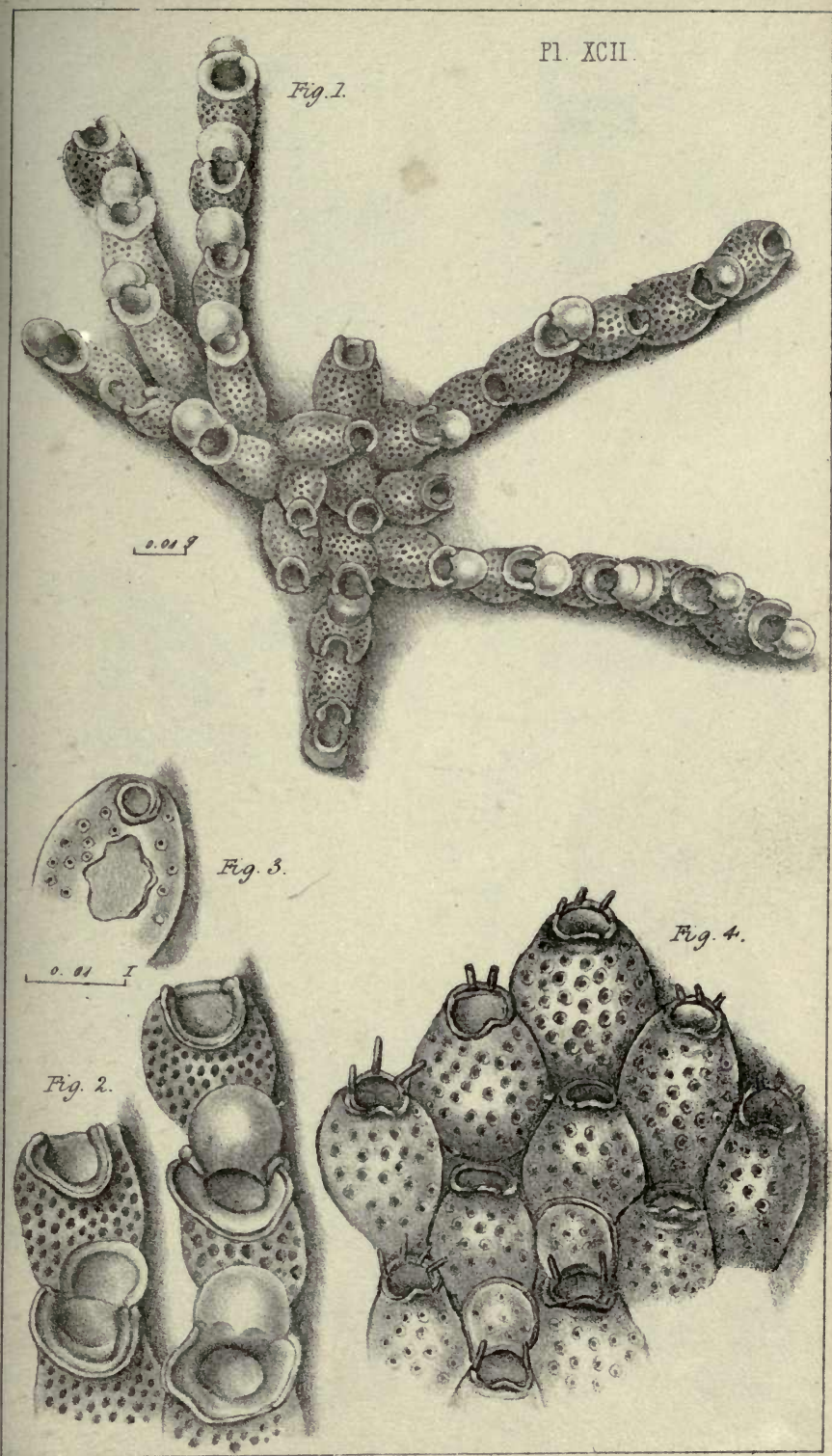

G. Busk, del 


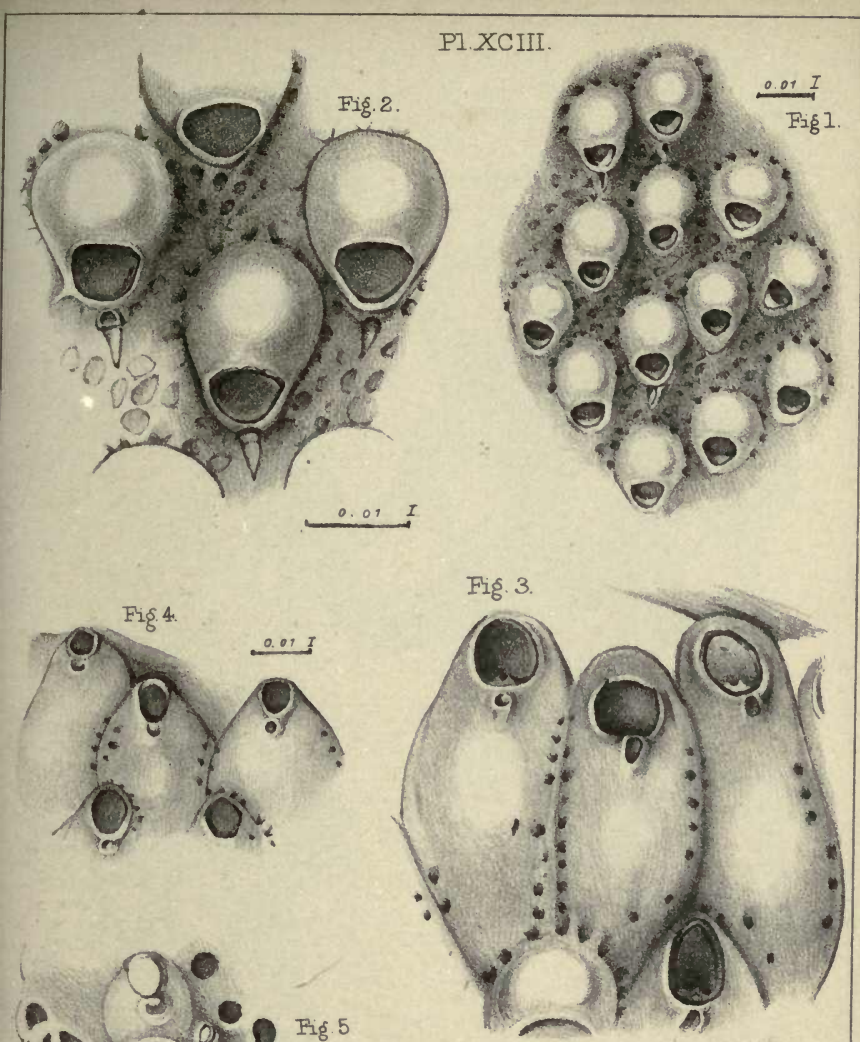

$\left.10 \quad 0^{\circ}\right)^{5}$
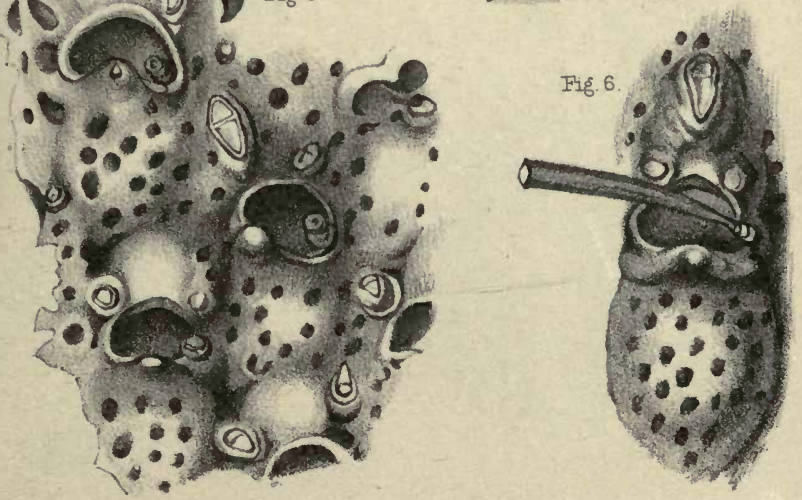




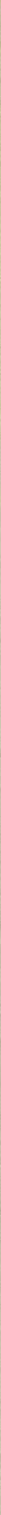

G. Bosk, del. CR Bone, lith. 



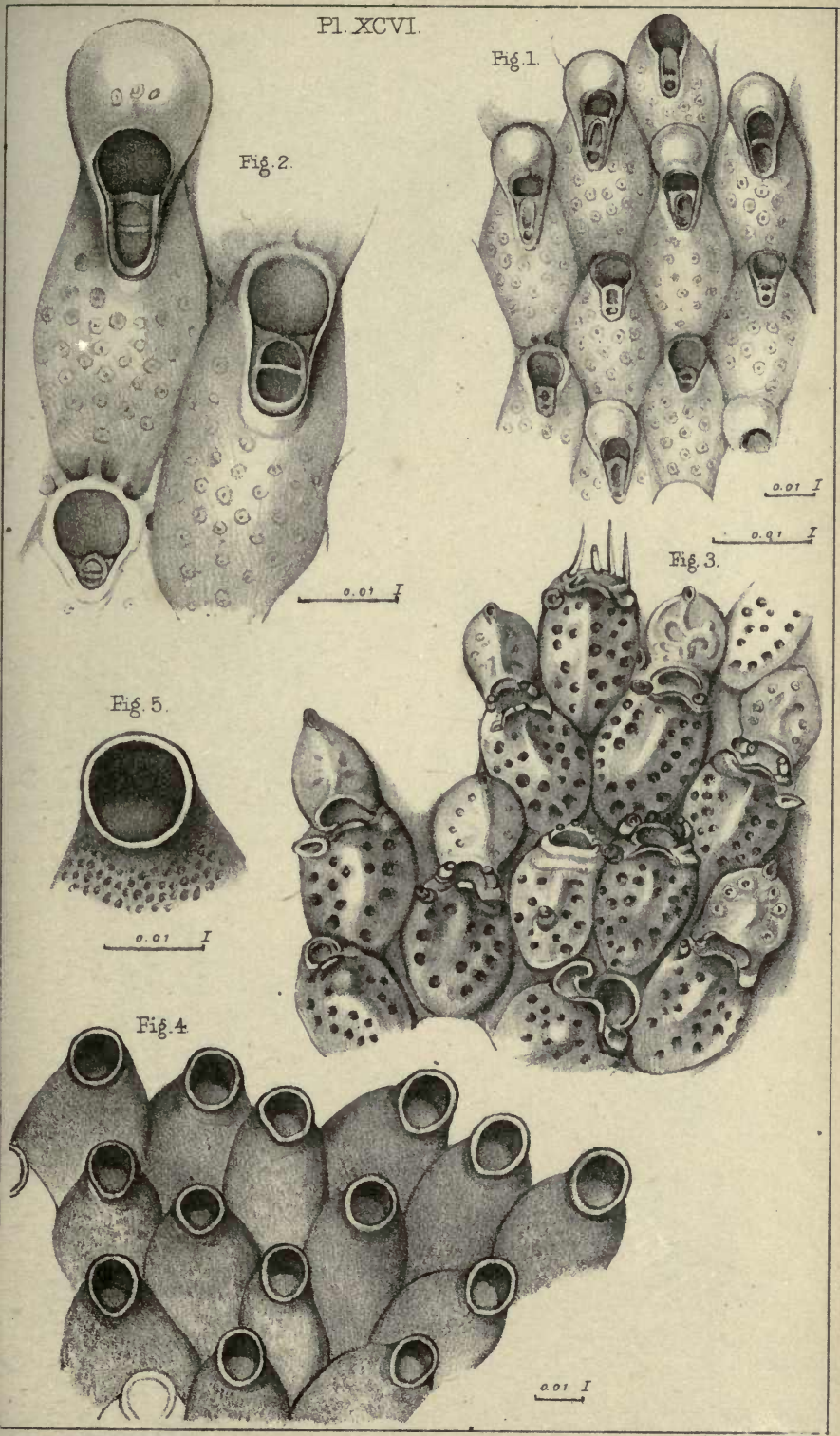




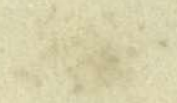

7

$2 x^{2}+5 x+5$

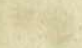




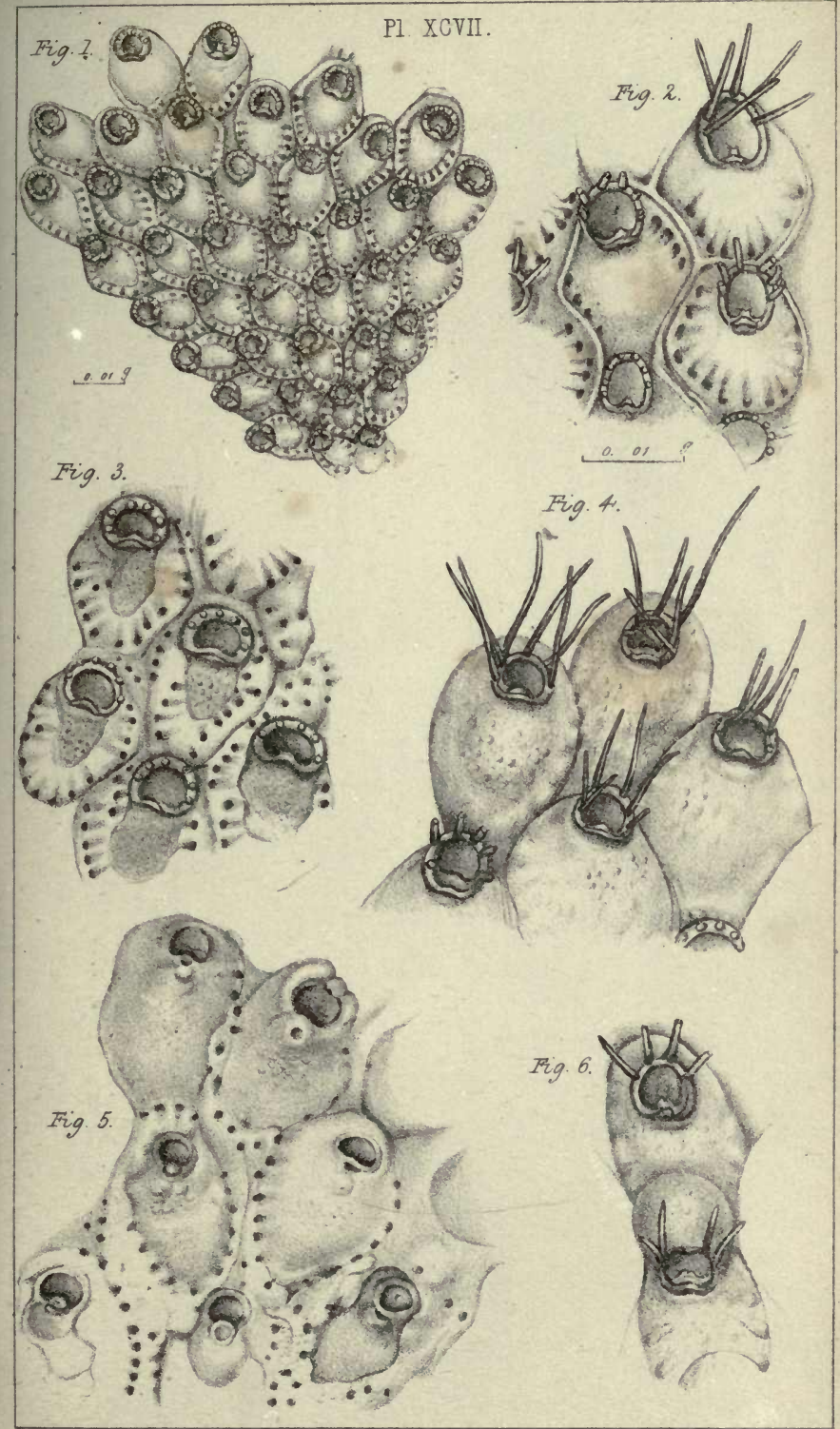





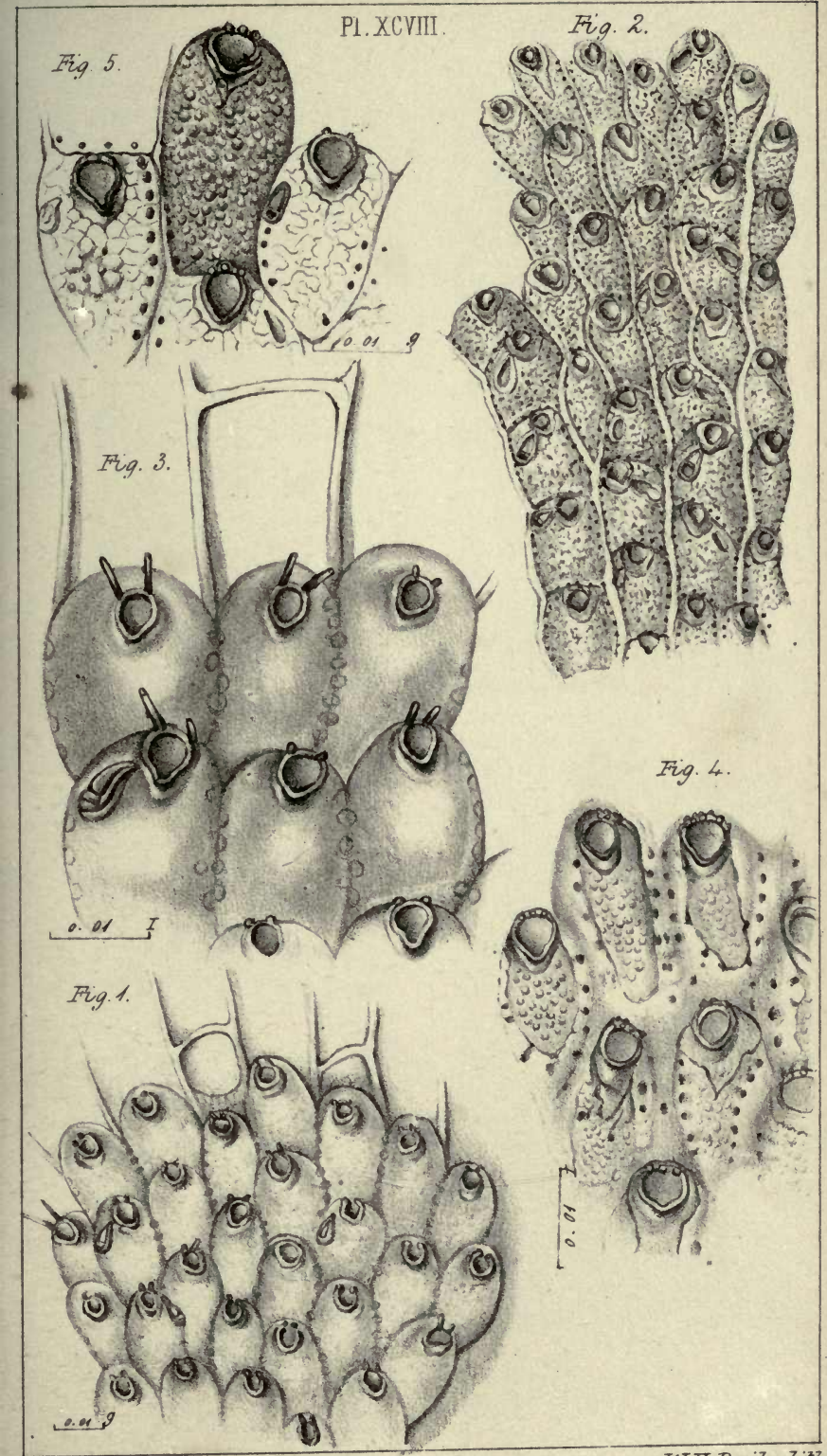

G. Busk, der. 



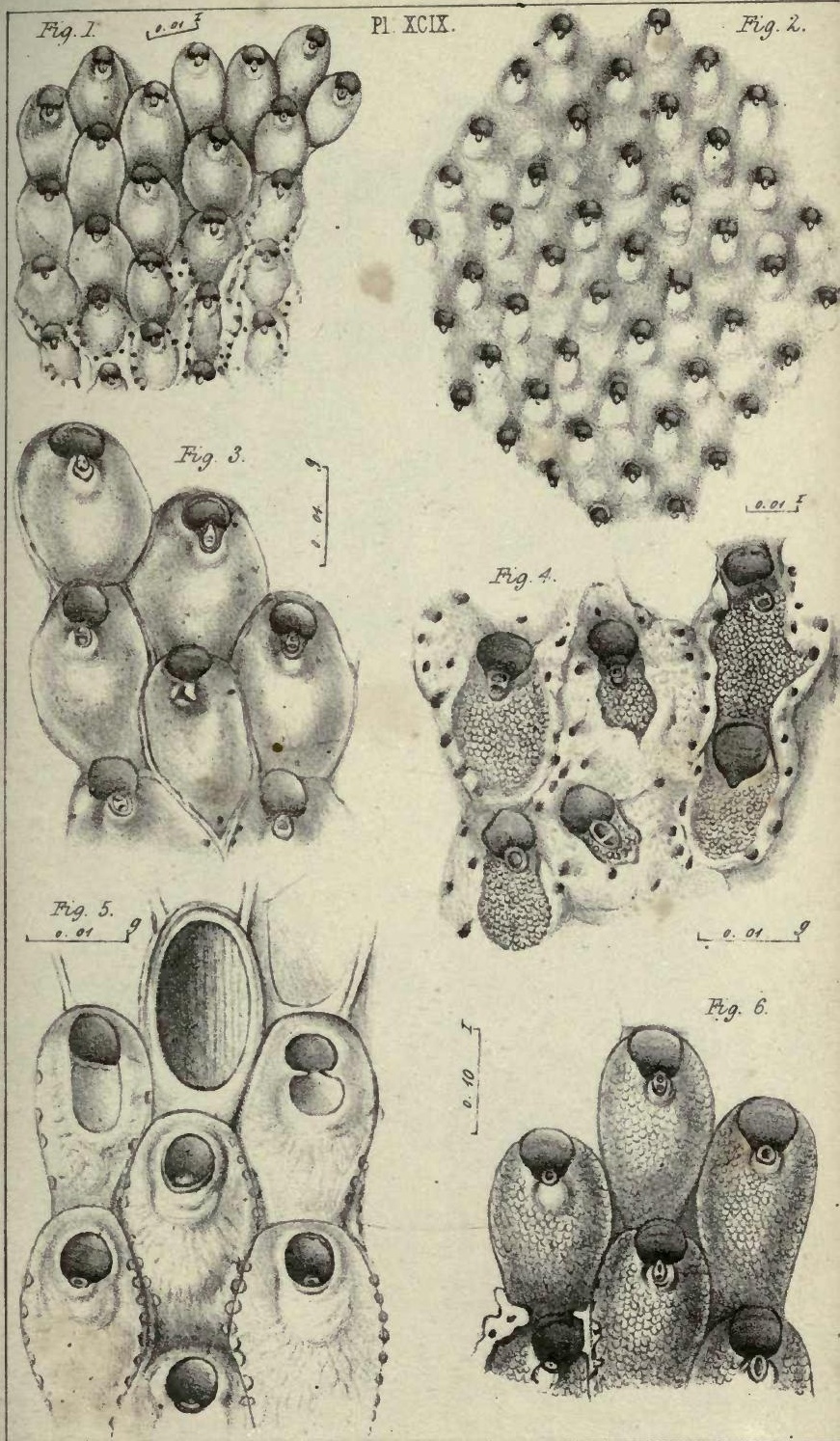

G. Busk, del. 
웅

5

$x^{4}$

axth

(t)

ats.

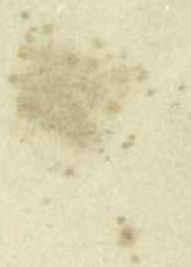

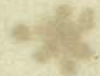





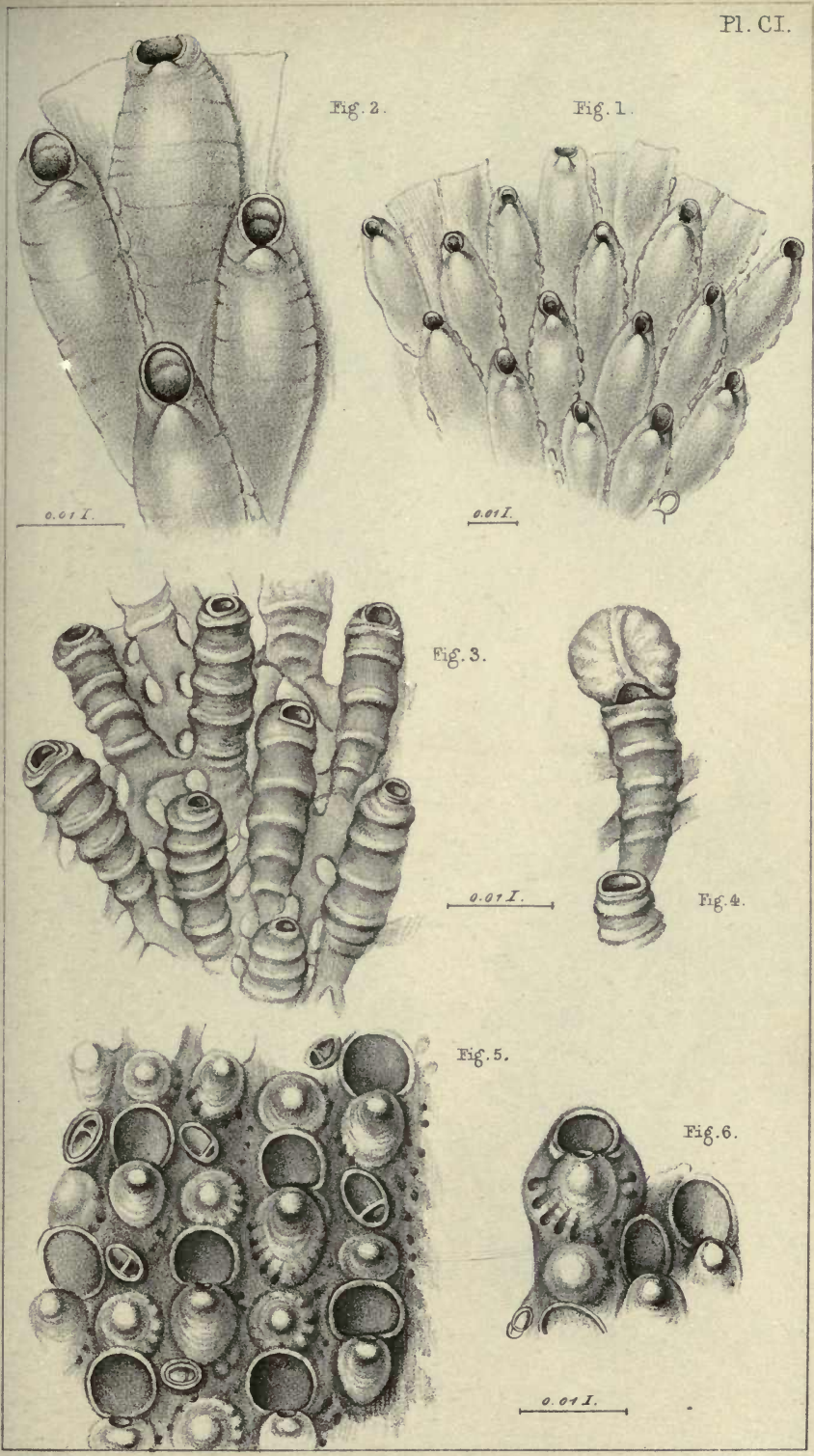

G Busk dal. 



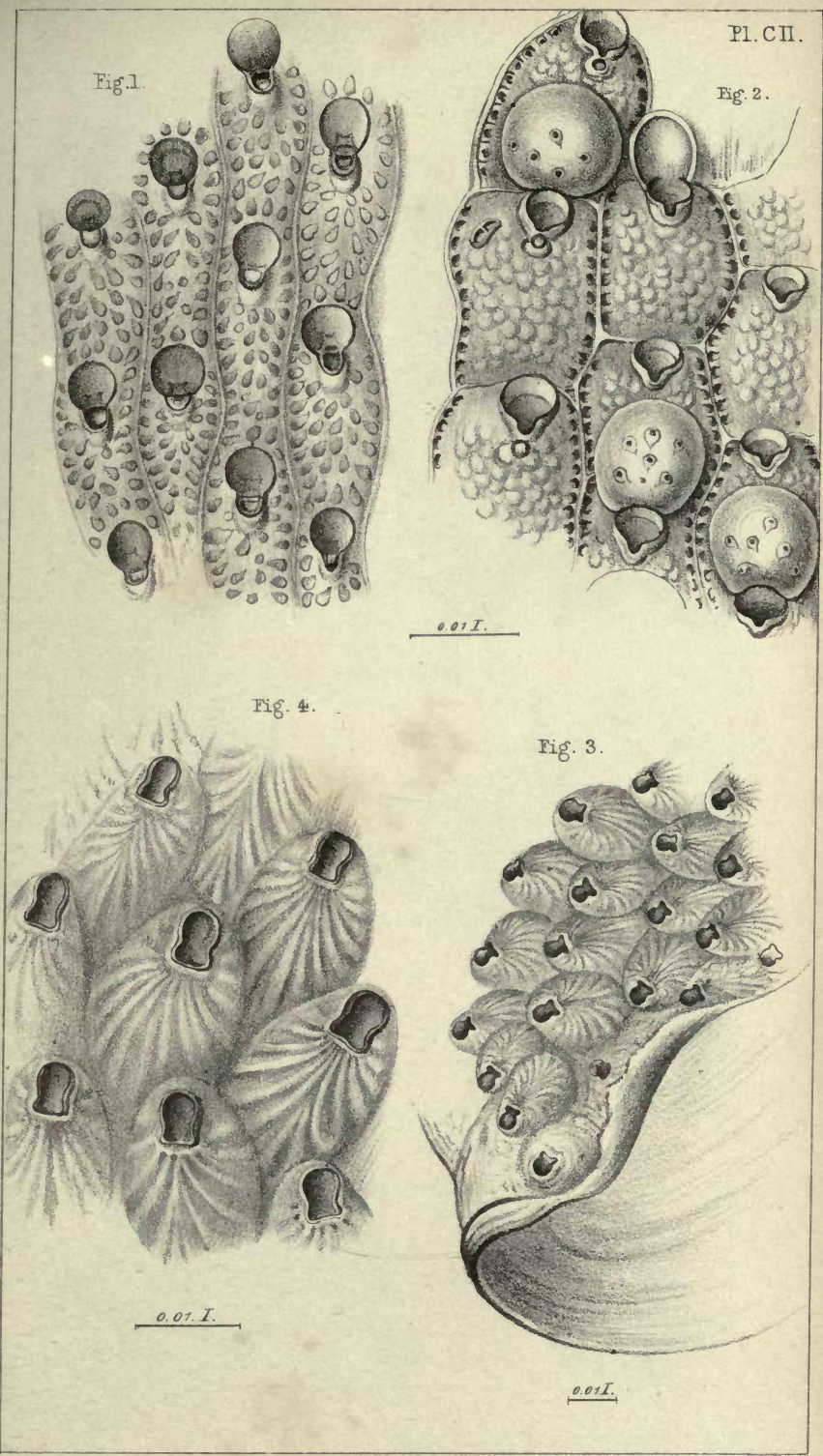





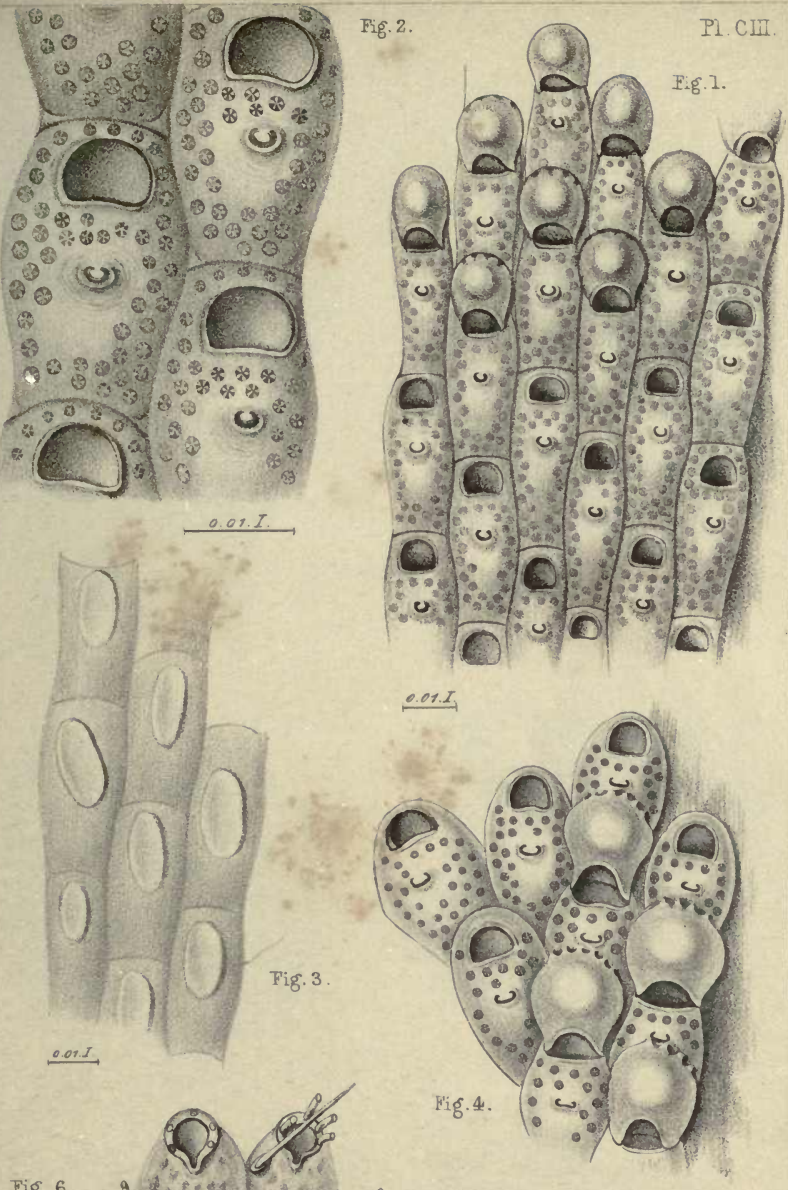

*

$$
1 \text { is } 8 \text { its }
$$

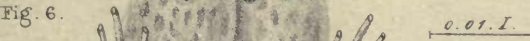

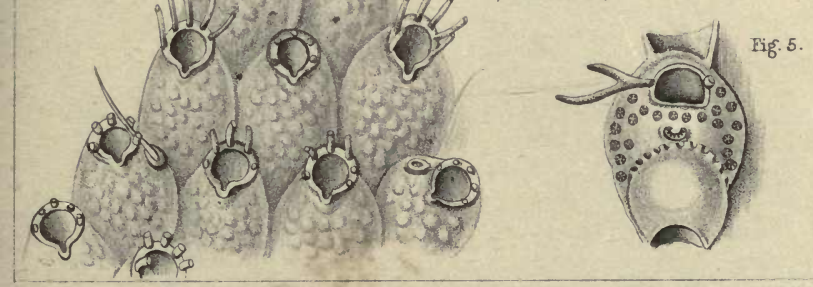




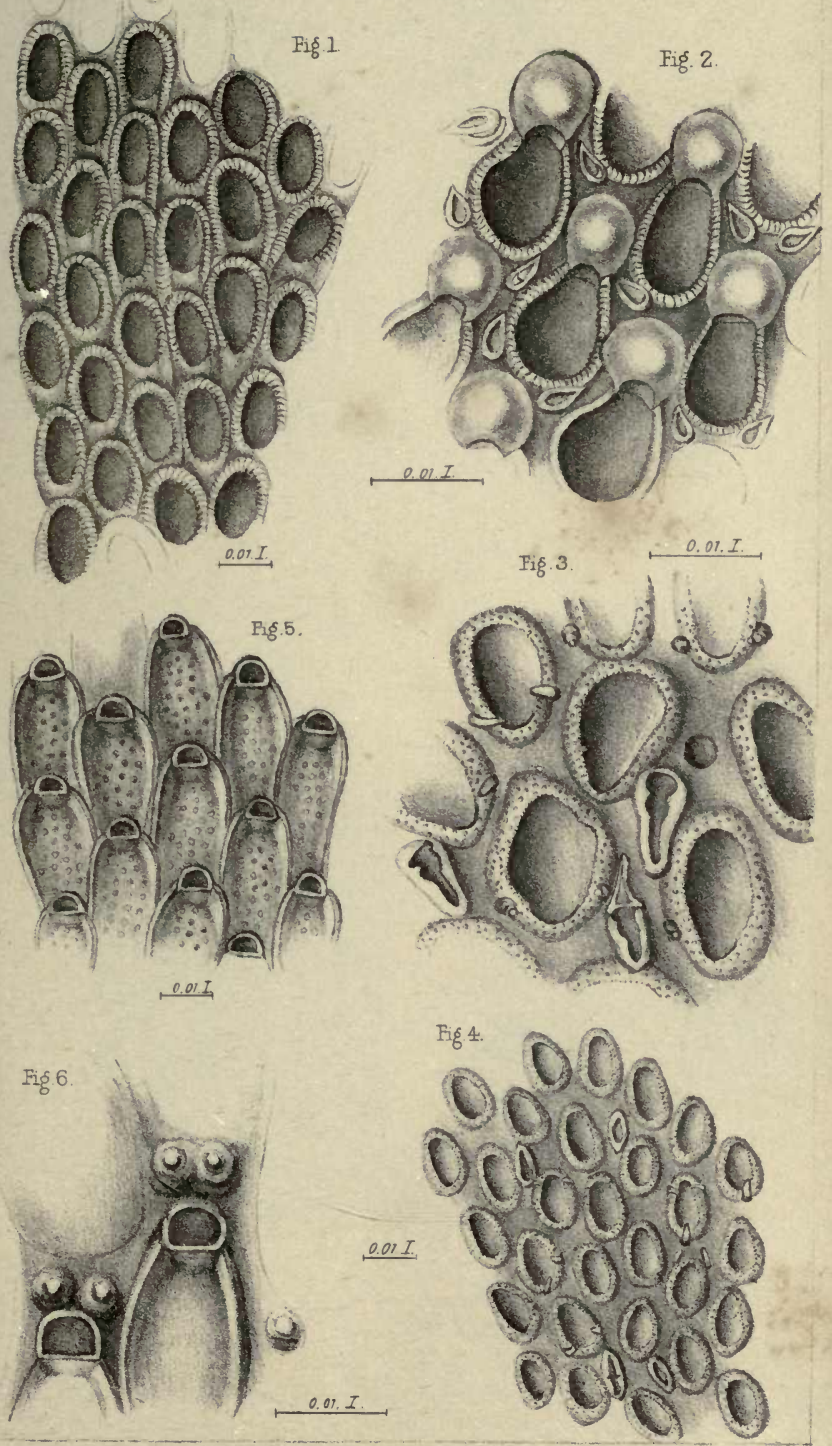
A.

$y^{4} x^{2}+$

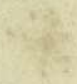

4

43
-303<smiles>C1C2CC12</smiles>

308

i. 


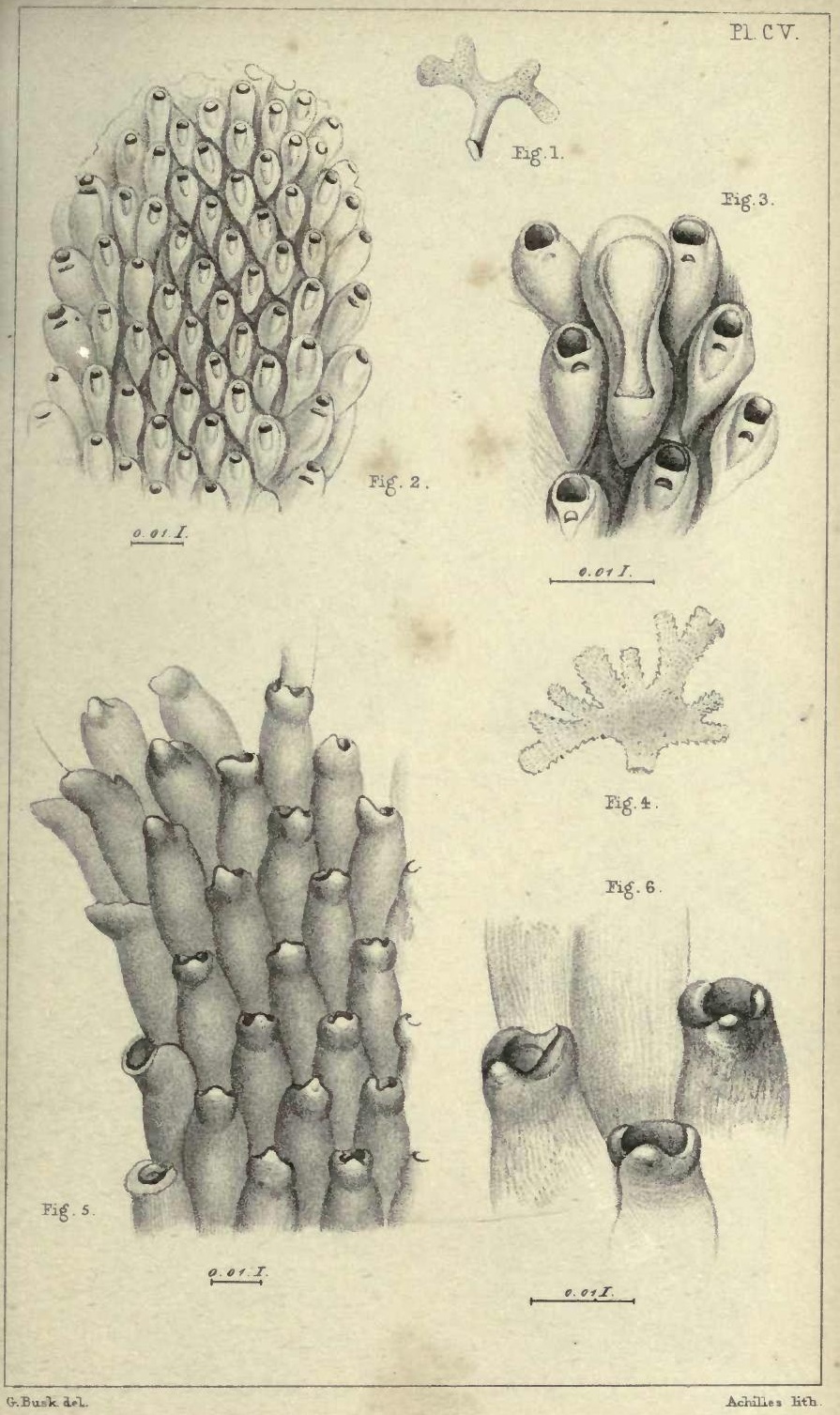




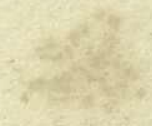





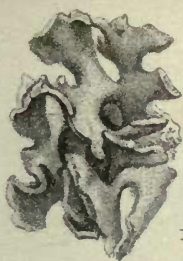

Fig.1.
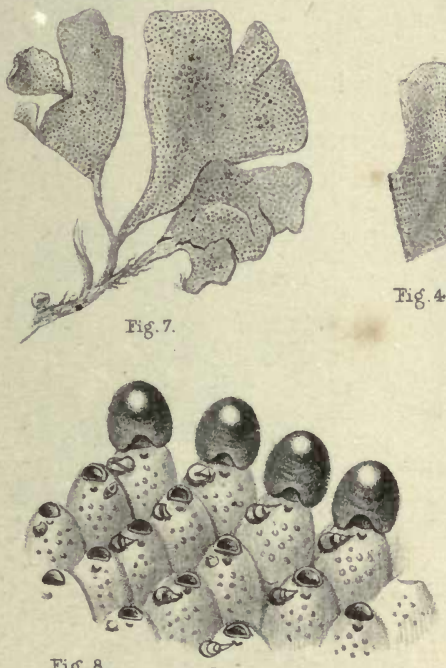

Fig. 8. $\quad 0.01$ I.

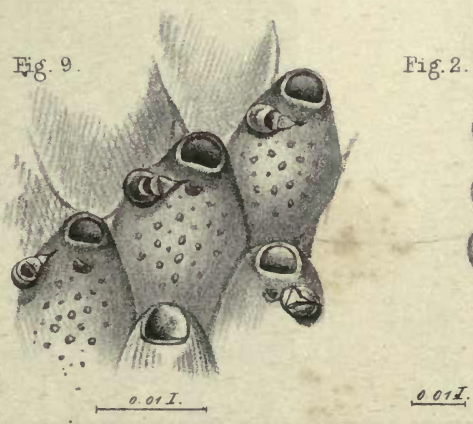

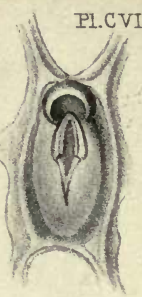

Fig.6.
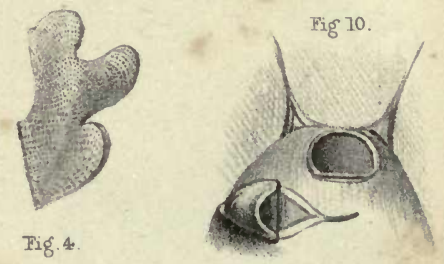

$0.07 I$.

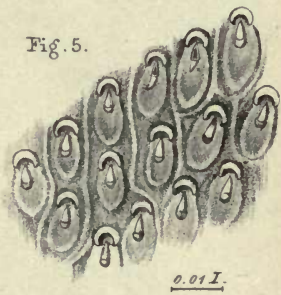

0.011.

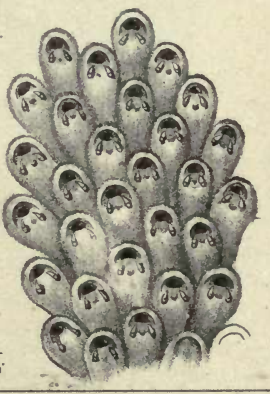



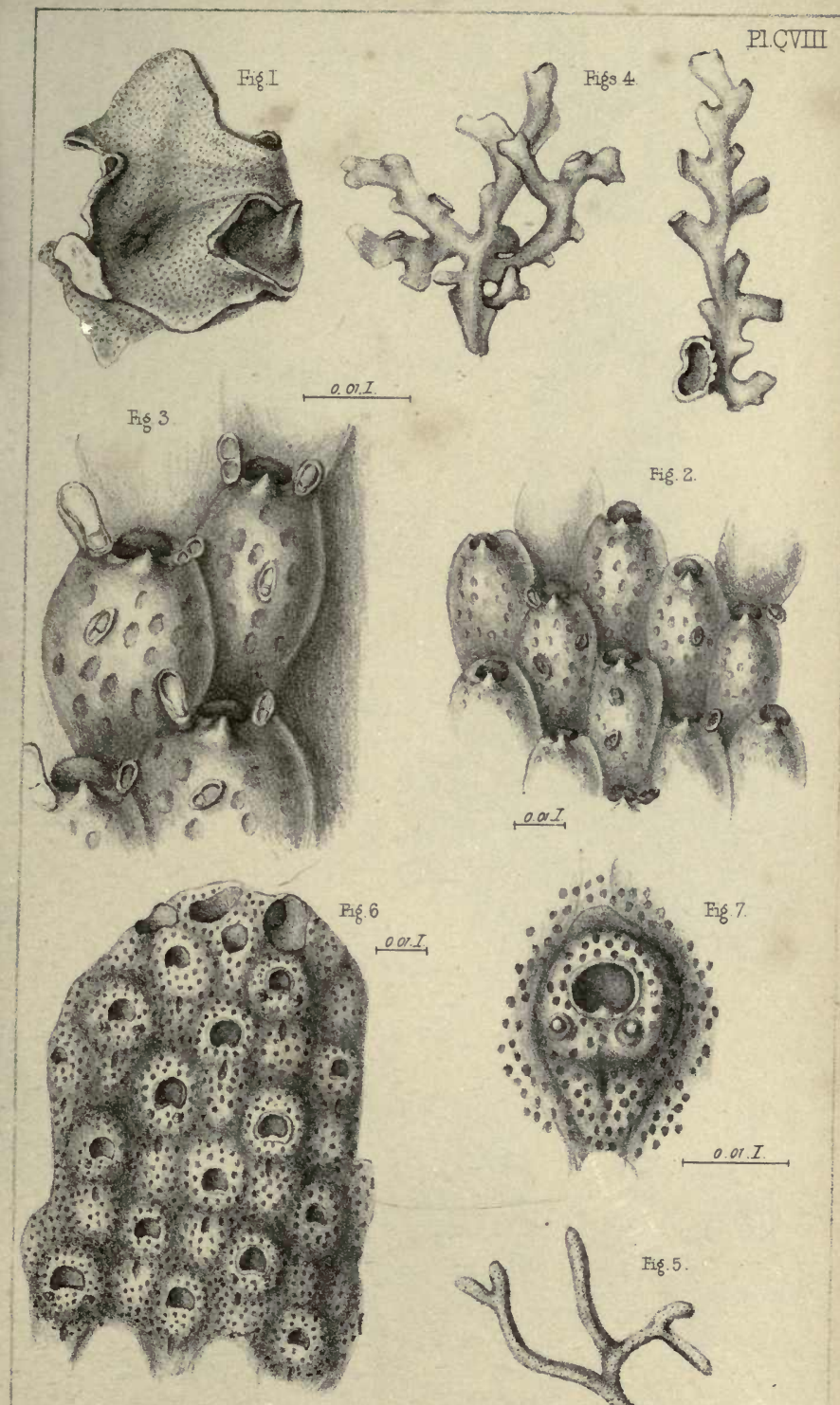



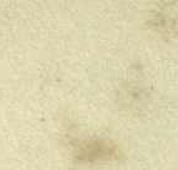

$3+2 \times 4=$
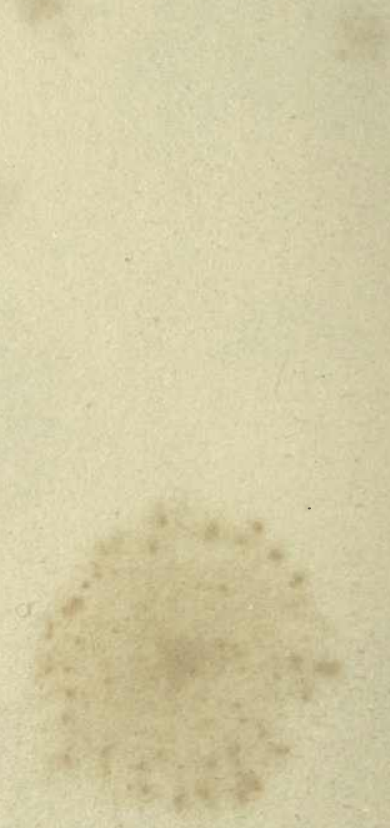


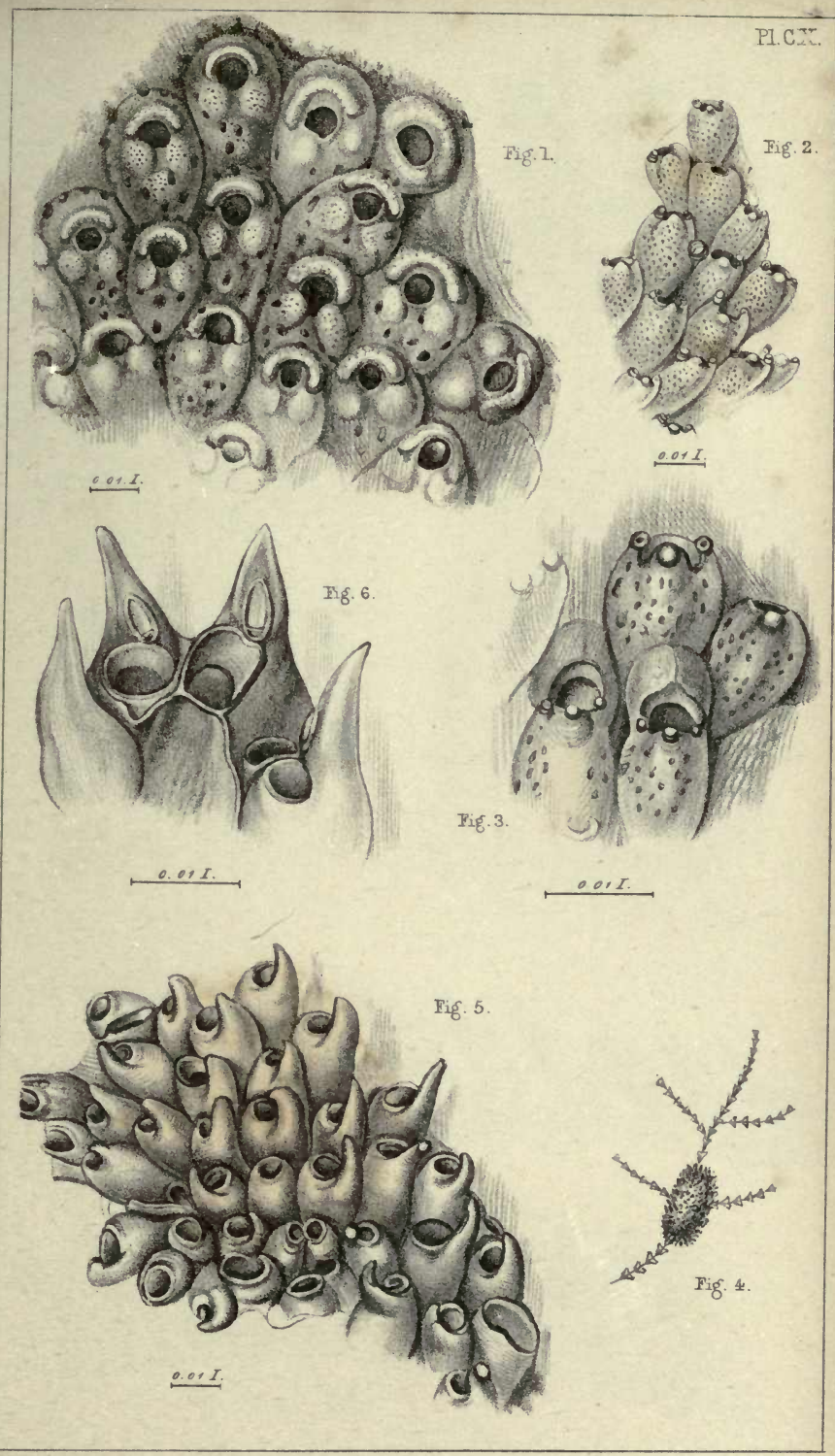





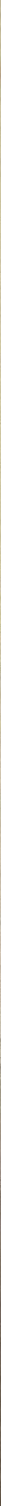





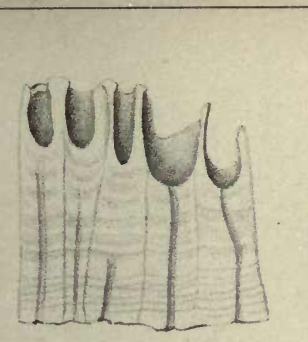

Fig. 5.

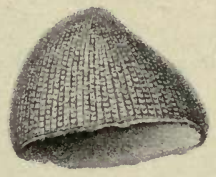

Fig. 1.

Pl. CXII.
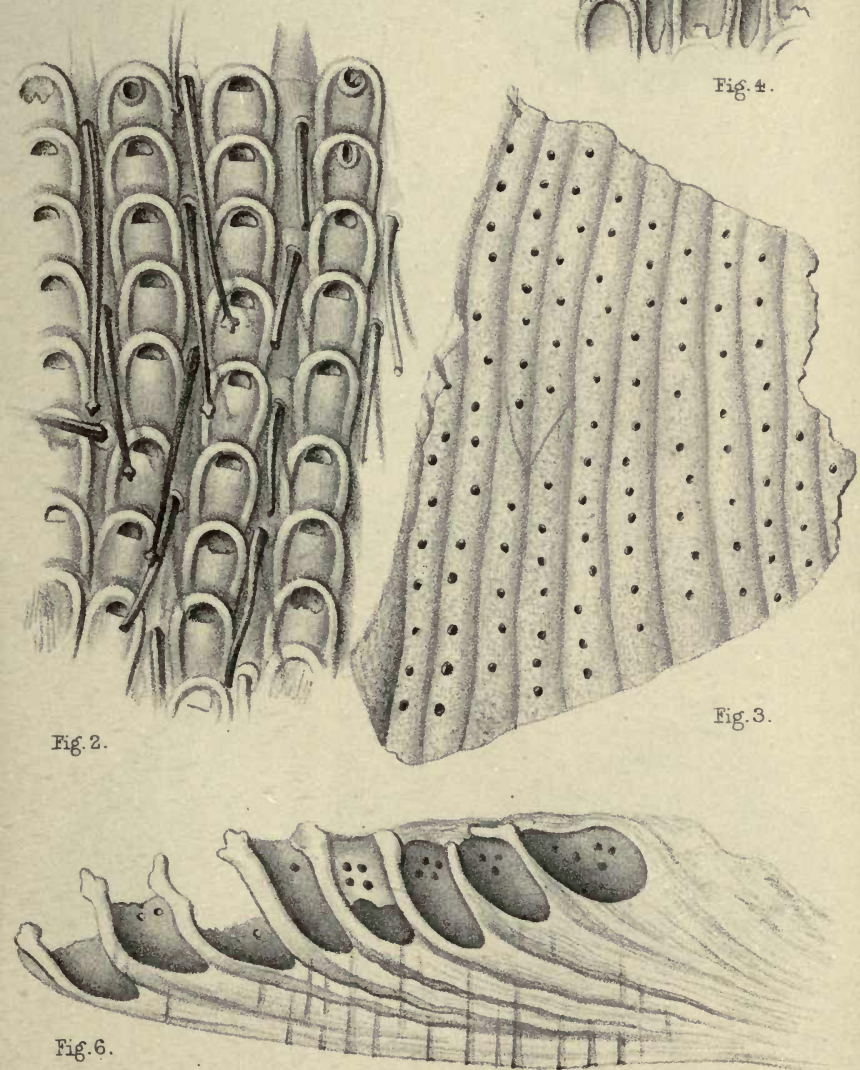

$13.0 .0 .00 \%$

$\therefore 90: 000$

C: :00: :00?

Gro $800: 50$

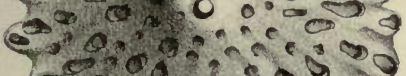

$530^{\circ} .1900^{2}$ (e) 3313$)$

Fig. 2.
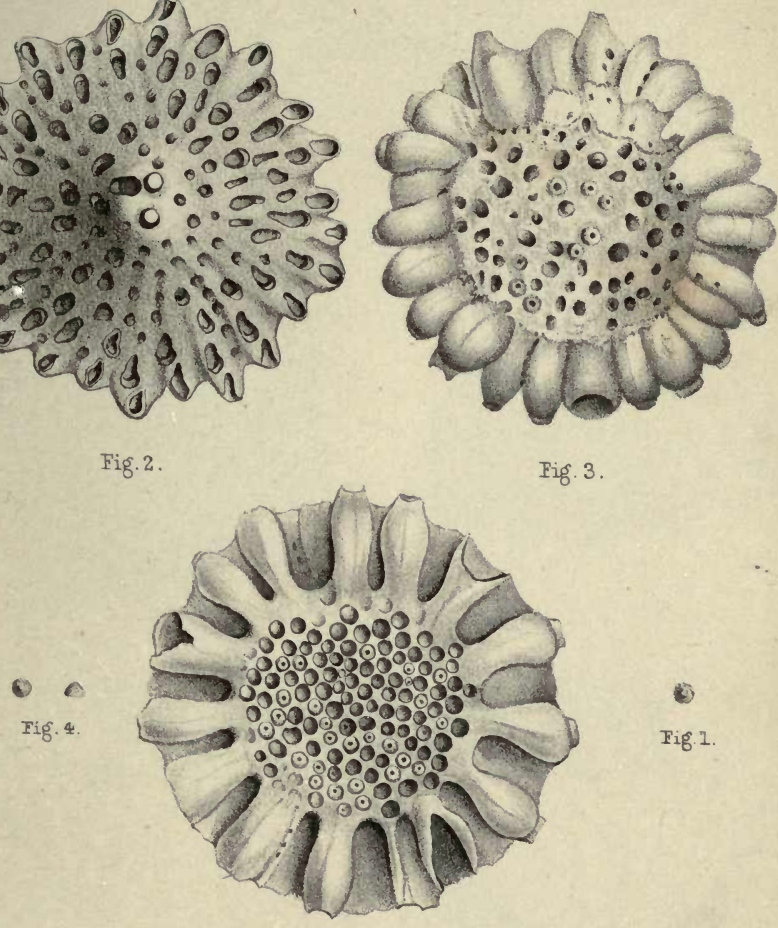

Fig. 3.

Fig. 6

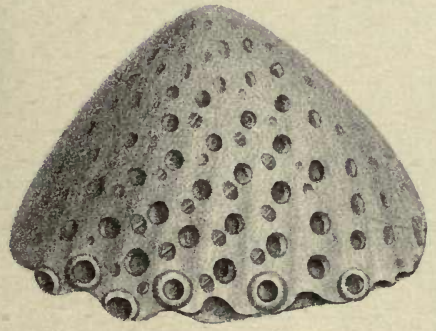

Fig. 5.

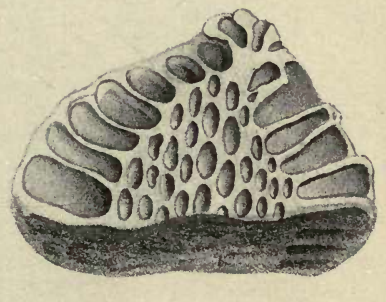

Fig. 7.
(2)

Fig. 1. 
tiv 
(n)

ays

1

a.

zis 


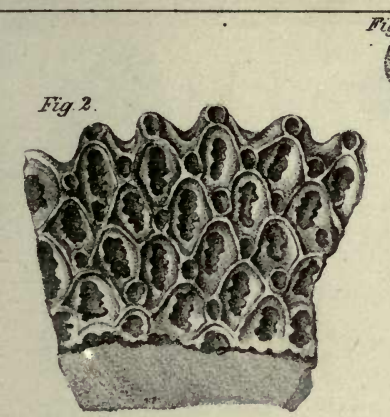

FI CXY (i)
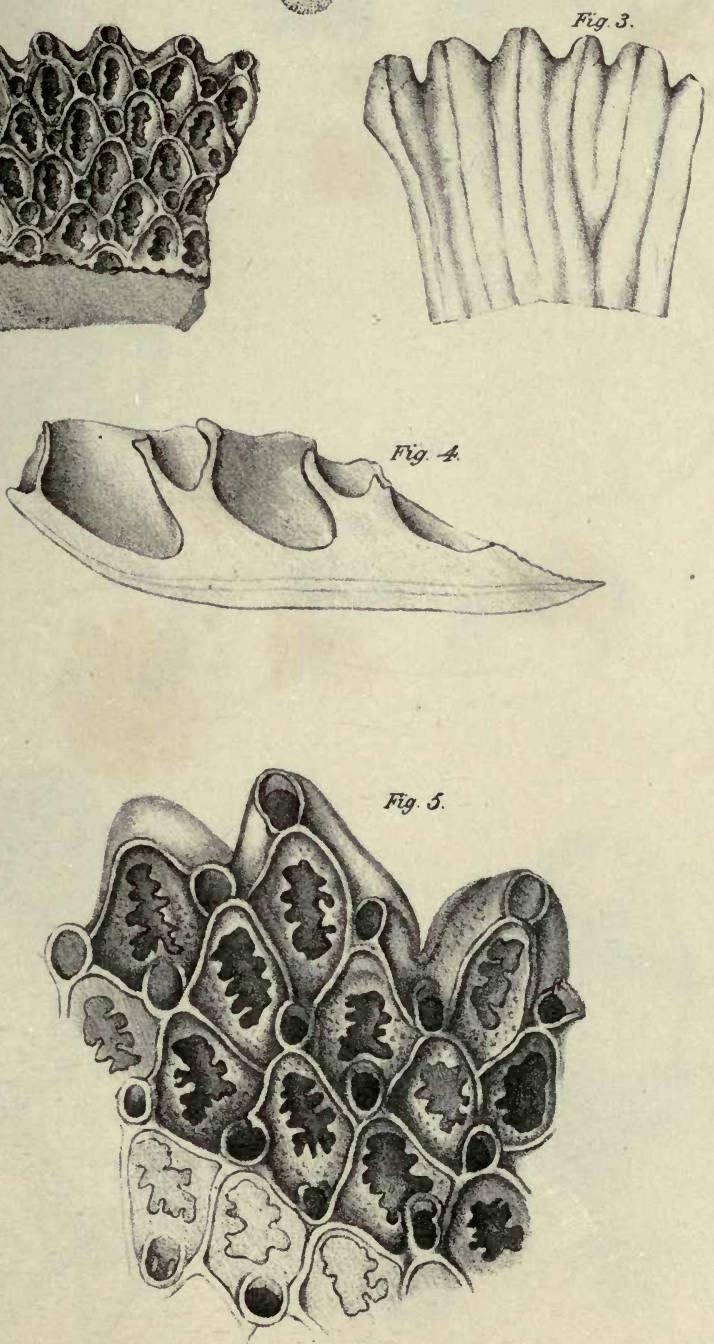



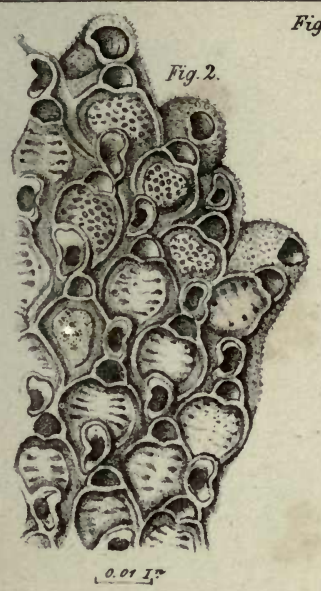

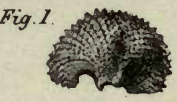
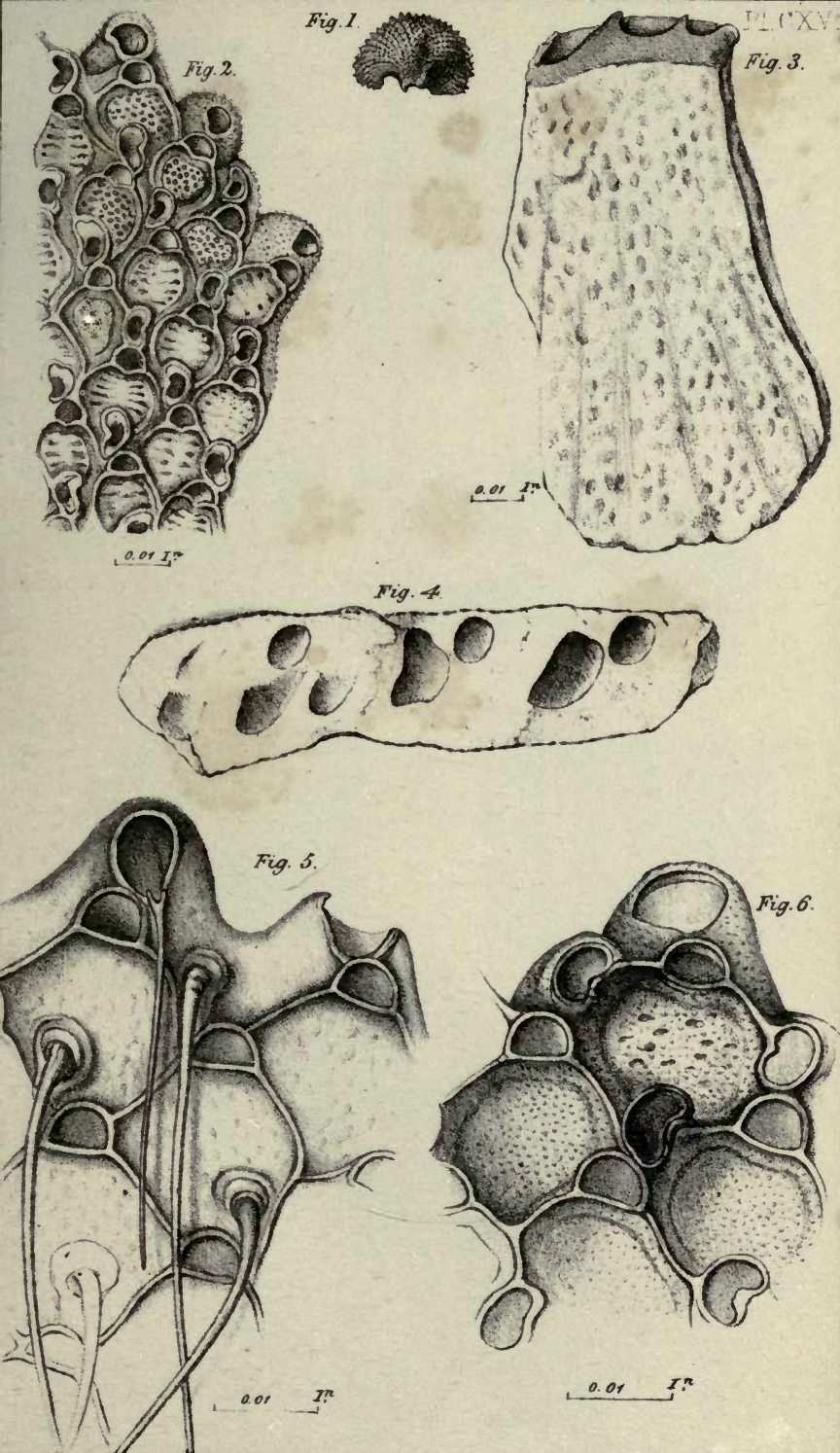



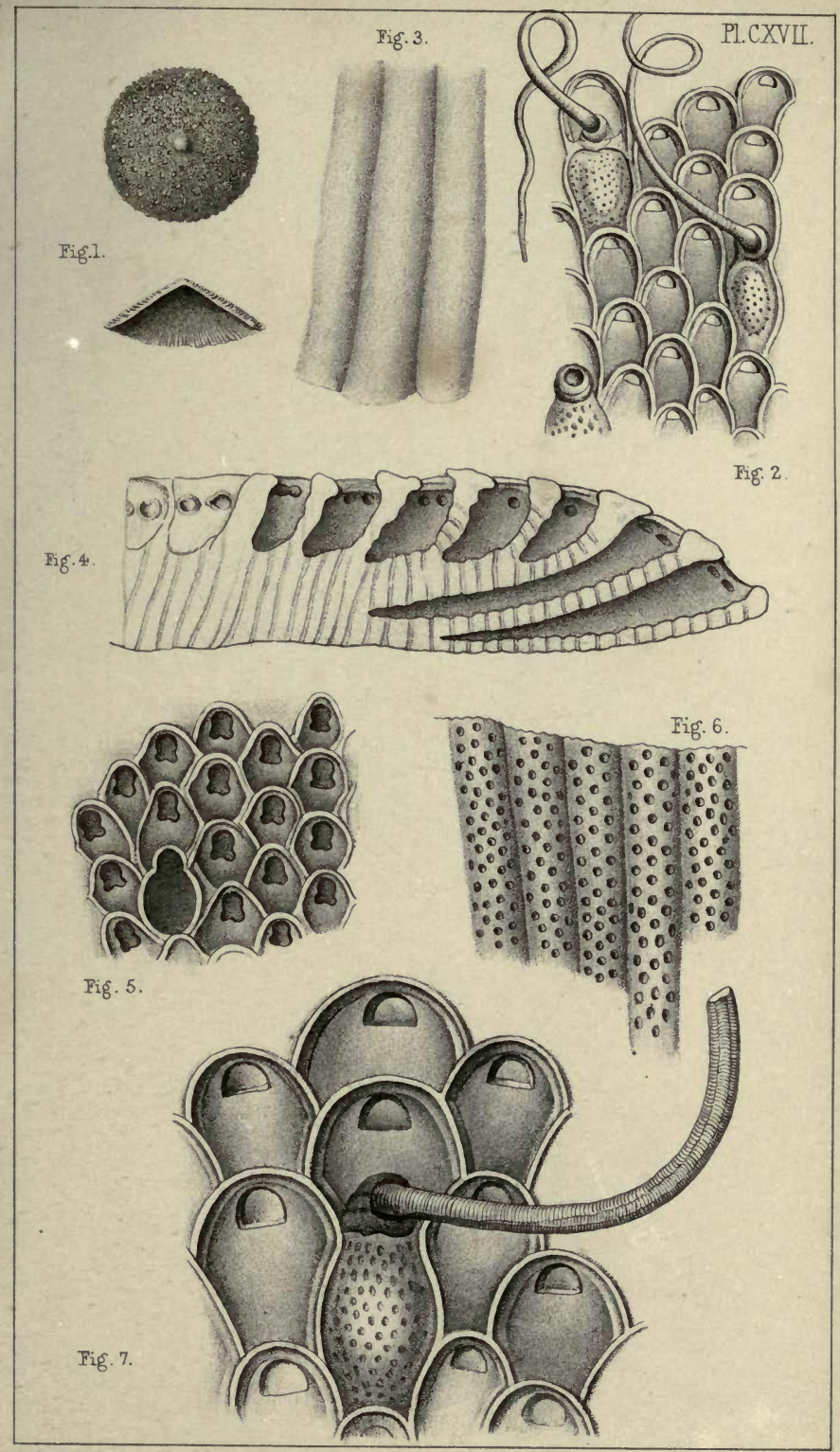




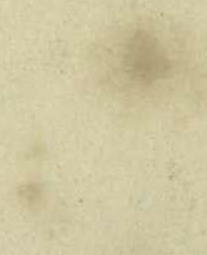

$$
45
$$$$
3
$$ 


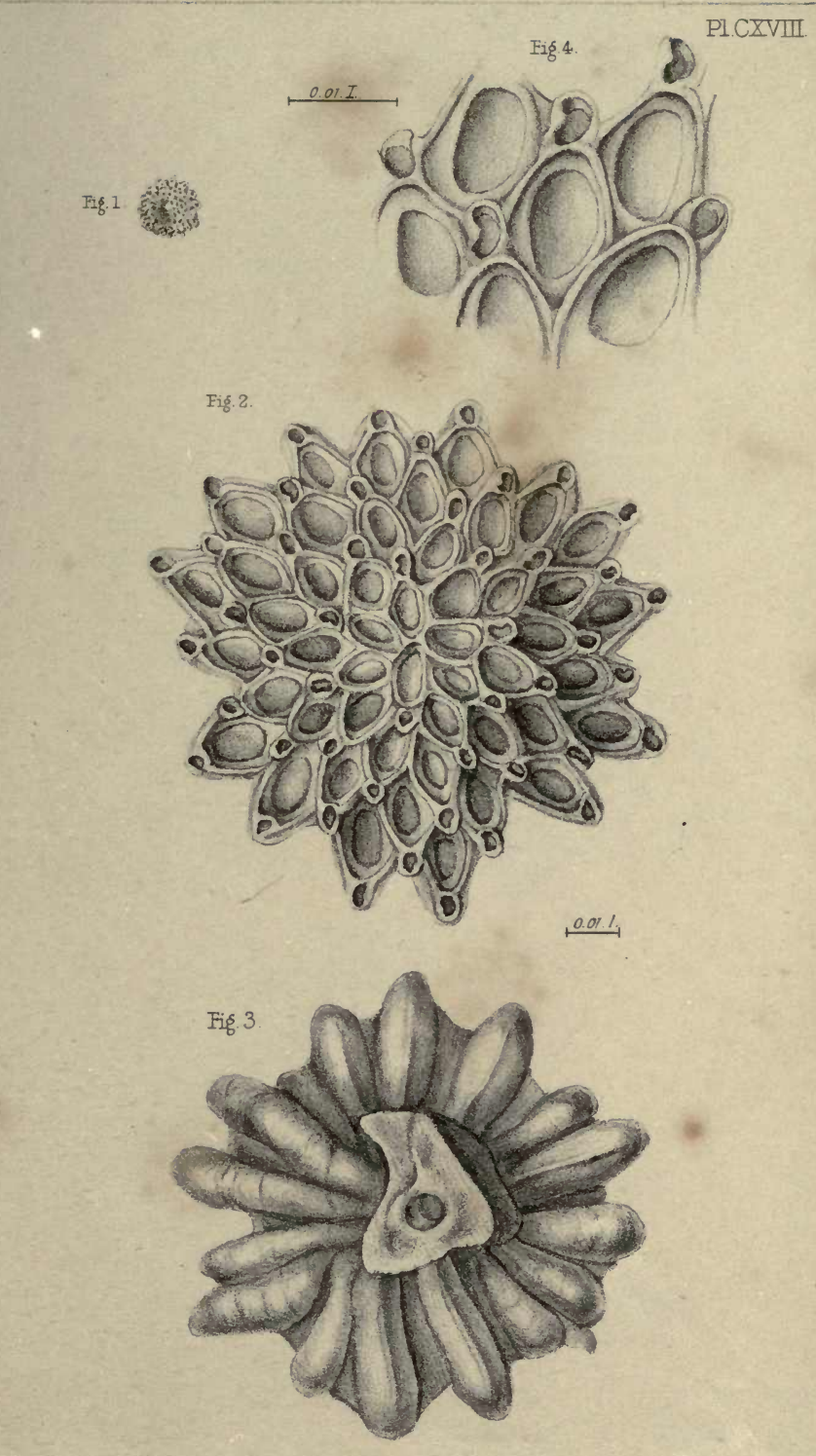




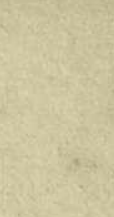

t5

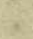

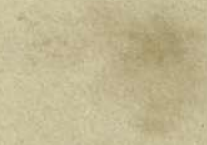

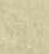

$\left(-3 x+3 y^{2}\right.$

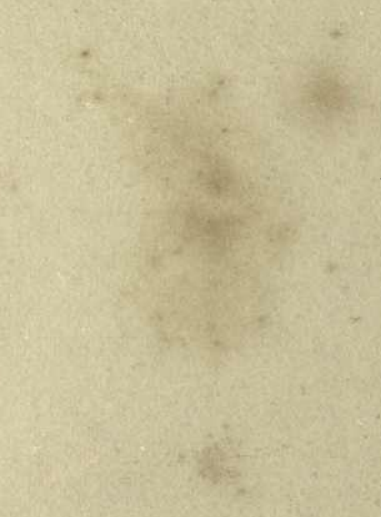

19.

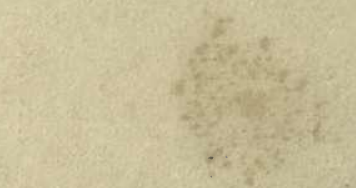

ats

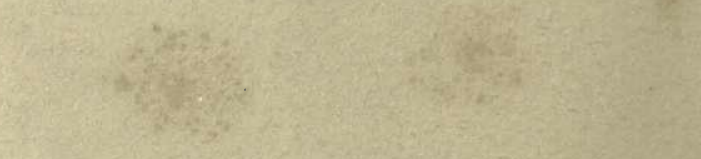





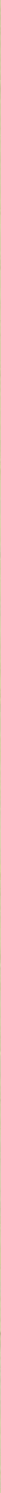

GBusk. de्. CRBonelith F'ord \& West. Imv. 



\section{CXXI.}

Fig. I.
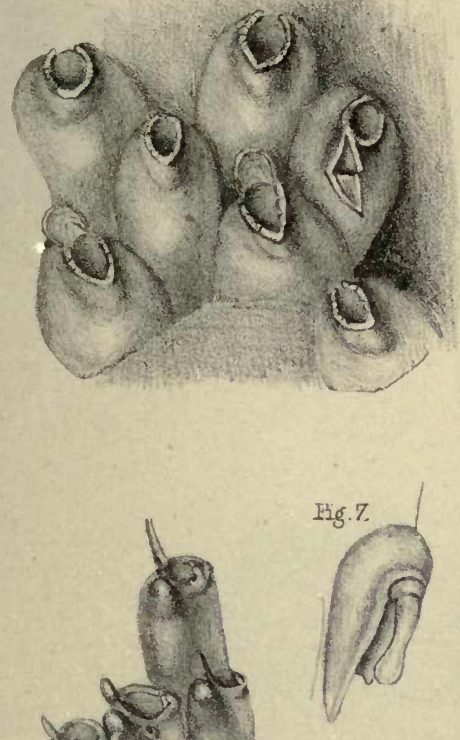

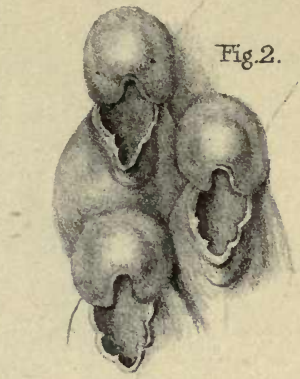

and

r.teing a Fig.6. dempt

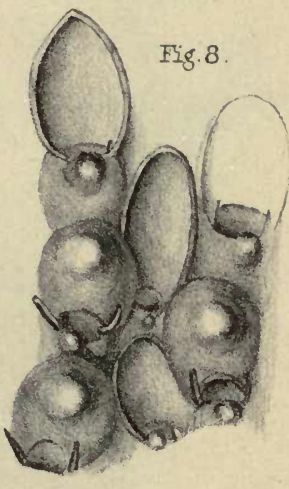

Fig. 5.

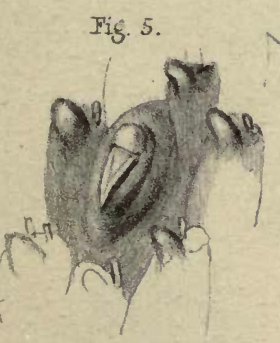




Fig. 1.
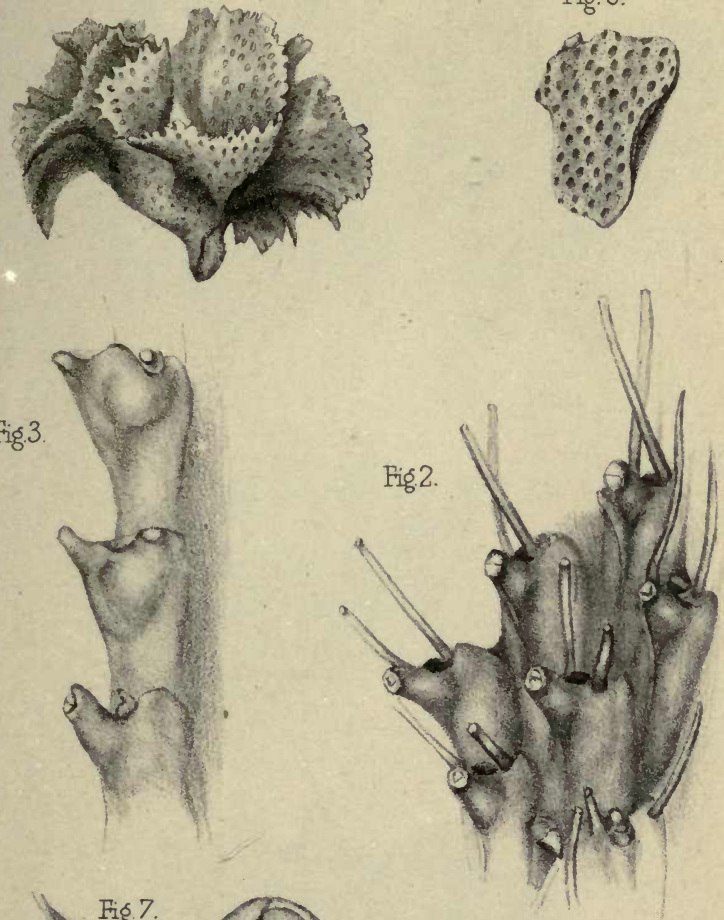

Fig.3.

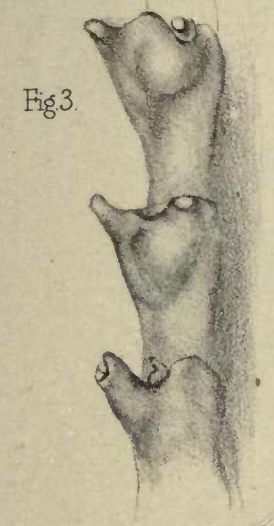

Fio. 6.

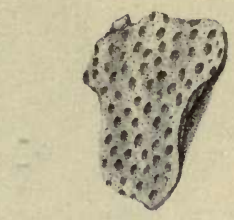

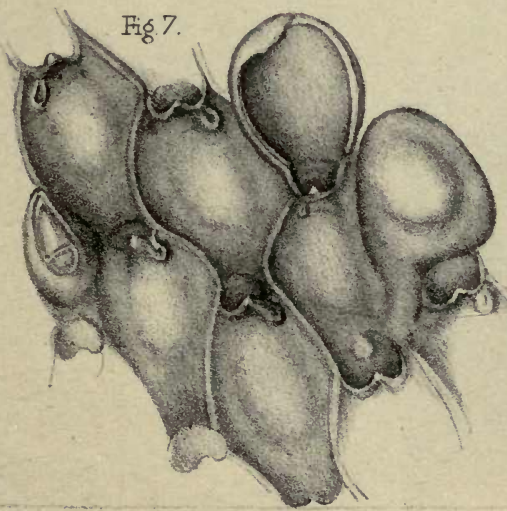
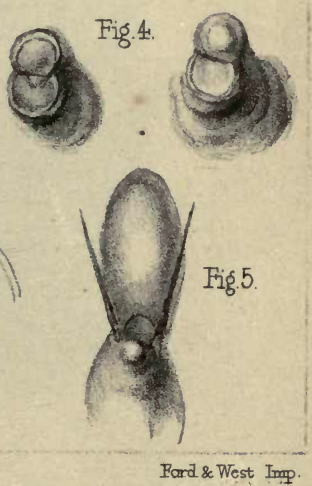

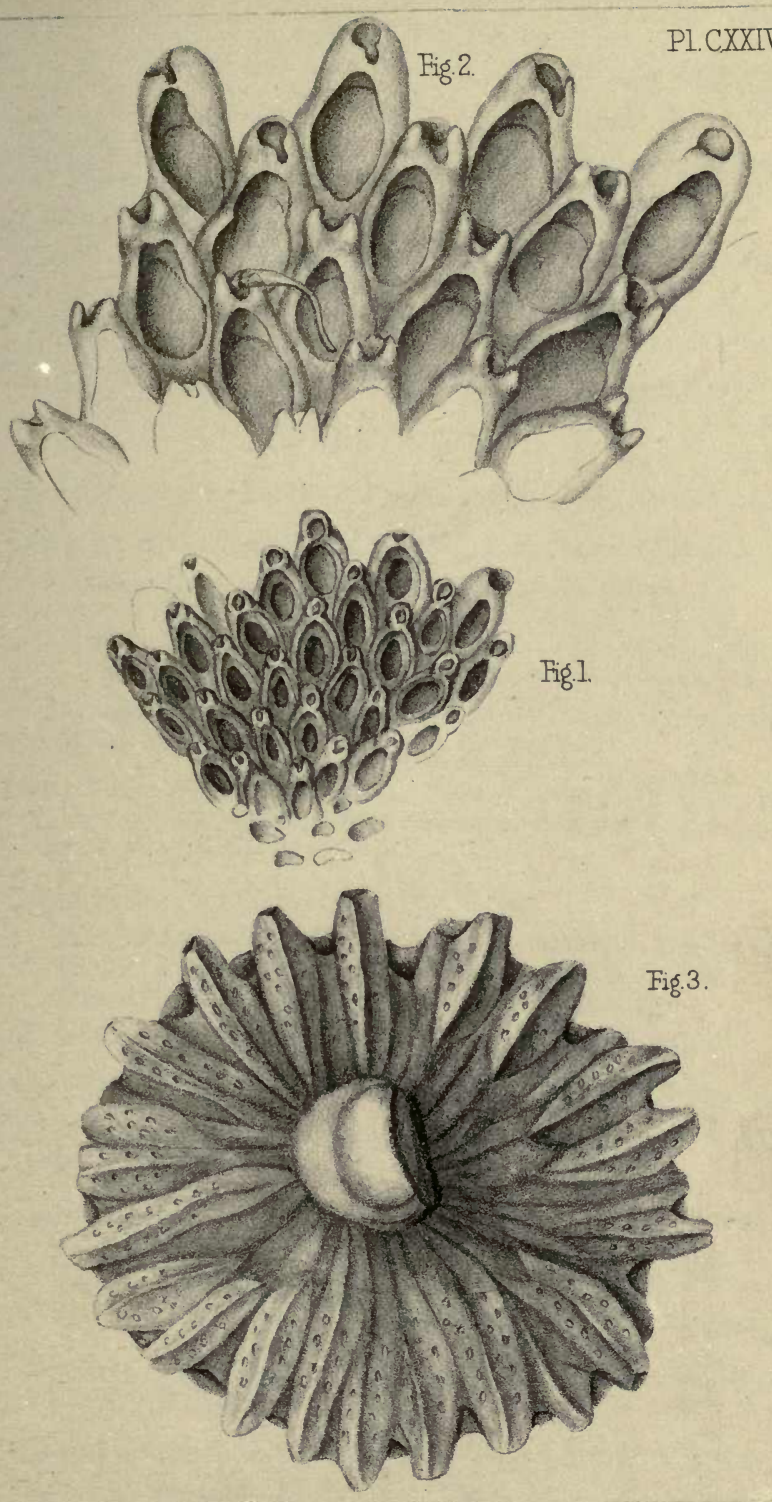

G. Busk del .et lith. 



\section{CATALOGUES}

OF

\section{THE ZOOLOGICAL COLLECTION}

\section{IN \\ THE BRITISH MUSEUM.}

\section{VERTEBRATA.}

List of Mammalia. By Dr. J. E. Gray, F.R.S. \&c. 1843. 2s.6d. Catalogue of the Mammalia. By Dr. J. E. Gray, F.R.S. \&c. Part 1. Cetacea. $12 \mathrm{mo}, 1850$. $4 s$., with Plates. Part 2. Seals. $12 \mathrm{mo}, 1850.1 s .6 d$., with Woodcuts.

Part 3. Hoofed Quadrupeds. Section I. (Ungulata furcipeda) 1852, with Plates of Genera, $12 s$.

This work contains the description of the genera and species, and figures of the chief characters of the genera.

List of Mammalia and Birds of Nepaul, presented by B. H. Hodgson, Esq., to the British Museum. By Dr. J. E. GraY and G. R. GraY. 1846. $2 s$.

List of Birds. By G. R. Gray, F.L.S. \&c.

Part 1. Raptorial. Edition 1, 1844 ; edition 2, 1848. $3 s$.

Part 2. Passeres. Section I. Fissirostres. 1848. $2 s$.

Part 3. Gallinæ, Grallæ and Anseres. 1844. $2 s$.

The other sections of the Passerine birds are in progress.

List of British Birds. By G. R. Gray, F.L.S. \&c. 1850. $4 s$.

List of the Eggs of British Birds. By G. R. GraY, F.L.S. \&c. 1852. 2s. 6 d.

Catalogue of Reptiles. By Dr. J. E. Gray, F.R.S., V.P.Z.S. \&c.

Part 1. Tortoises, Crocodiles and Amphisbænians. 1844. $1 s$.

Part 2. Lizards. 1845. 3s. $6 d$.

Part 3. Snakes (Crotalidæ, Viperidæ, Hydridæ and Boidæ). 1849. 2s. $6 d$.

Part 4, completing the Snakes (Colubridæ), is in preparation.

Catalogue of Amphibia. By Dr. J. E. GraY, F.R.S., V.P.Z.S.

Part 2. Batrachia Gradientia. 12mo, 1850. 2s. 6d. with Plates of the Skull and Teeth. 
Catalogue of Fish. By Dr. J. E. Gray, F.R.S., V.P.Z.S,

Part 1. Cartilaginous Fish. 12mo, 1851. 3s. With two Plates.

These Catalogues of Reptiles, Amphibia, and Fish, contain the characters of all the genera and species at present known; the latter are illustrated with figures of the genera.

List of British Fish ; with Synonyma. By A.White, F.L.S. \&c. 1851. $3 s$.

List of Osteological Specimens. By Dr. J. E. Gray, F.R.S. \&c. and G. R. GRAY, F.L.S. 1847. $2 s$.

\section{ANNULOSA.}

Catalogue of Lepidoptera. By G. R. Gray, F.L.S.

Part 1. Papilionidæ, with coloured figures of the new species. $£ 1: 5 s$. 4 to, 1852.

List of Lepidopterous Insects. By E. Doubleday, F.L.S.

Part 1. Papilionidx, \&c. 1844. 2s. $6 d$.

Part 2. Erycinidæ, \&c. 1847. 9d.

Part 3. Appendix to Papilionidæ, Erycinidx, \&c. 1848. 9d.

List of Hymenopterous Insects. By F. WALKER, F.L.S.

Part 1. Chalcididx. 1846. 1s. $6 d$.

Part 2. Additions to Chalcididæ. 1848. $2 s$.

Catalogue of Hymenopterous Insects. By Frederick Smith, M.E.S.

Part 1. Andrenidæ, \&c. 1853. 2s. $6 d$., with Plates.

Catalogue of Dipterous Insects. By F. WALKER, F.L.S.

Part 1. 1848. 3s. $6 d$.

Part 2. 1849. 3s. 6d.

Catalogue of Homopterous Insects. By F. WALKer, F.L.S.

Part 1. 1850. 3s. $6 d$.

Part 2. 1850. 5s.

Part 3. 1851. 3s. $6 d$.

Catalogue of Neuropterous Insects. By F. WALKer, F.L.S.

Part 1. 1852. 2s. $6 d$.

Part 2. 1853. 3s. $6 d$.

Part 3. 1849. $3 s$.

Part 4. 1849. 6s.

Part 4. 1852. 4s., with Plates.

Part 3. 1853 . 1s. $6 d$.

The Catalogues of Hymenopterous, Dipterous, and Homopterous Insects contain the description of the species in the Museum which appeared to be undescribed. 
Catalogue of Hemipterous Insects. By W. S. Dallas, F.L.S.\&c.

With Plates, Part 1. 1851. 7s. Part 2. 1852. 4s.

The Catalogue of Hemiptera contains the description of the new species in the Museum Collection, and figures of the more interesting genera.

Nomenclature of Coleopterous Insects (with characters of new species).

Part 1. Cetoniadæ. 1847. 1s. By A. White, F.L.S. \&c.

Part 2. Hydrocanthari. 1847. 1s. $3 d$. By A. White, F.L.S.

Part 3. Buprestidæ. 1848. $1 s$. By A. White, F.L.S.

Part 4. Cleridx. 1849. $1 s .8 d$. By A. White, F.L.S.

Part 5. Cucujidæ. 1851. 6d. By F. Sмiтh, M.E.S.

Part 6. Passalidæ. 1852. 8d. By F. Sмiтн, M.E.S.

Part 7. Longicornia, with Plates, 1853. 2s.6d. By A. W HITE, F.L.S.

List of Crustacea; with Synonyma. By A. White. 1847. $2 s$. List of Myriapoda. By G. NEw porT, F.R.S. \&c. 1844. $4 d$. List of British Lepidoptera; with Synonyma. By J. F. STEP'Hexs, F.L.S. Part 1. 1850. 5s. Part 2. 1852. $2 s$. Part 3. 1853. $9 d$.

List of British Aculeate Hymenoptera; with Synonyma, and the description of some new species. By F. Sмiтr. 1851. $2 s$.

List of British Anoplura, or Parasitic Insects; with Synonyma. By H. Denny. $1 s$.

List of British Crustacea; with Synonyma. By A. White, F.L.S. 1850. $2 s .6 d$.

Catalogue of Entozoa; with Plates. By W. Baird, M.D., F.L.S. 1853. $2 s$.

\section{MOLLUSCA.}

Catalogue of the Mollusca in the Collection of the British Museum. By Dr. J. E. Gray, F.R.S., \&c.

Part 1. Cephalopoda Antepedia. 1849. $4 s$.

Part 2. Pteropoda. 1850. $1 s$.

Part 3. Placuniadæ and Anomiadx. 1850. $4 d$.

Part 4. Brachiopoda Ancylopoda; figures of genera. 1853. 3s.

Containing the characters of the recent and fossil genera, and the descriptions of all the recent species at present known.

Catalogne of Phaneropneumona or Operculated Terrestrial Mollusea. By Dr. Louis Pfeiffer. 1852. $5 s$.

Catalogus Concharum Bivalvium. By M. G. P. Deshayes.

Part 1. Veneridæ, \&c. 1853. 3s. 
List of British Mollusca and Shells; with Synonyma. By Dr. J. E. Gray, F.R.S.

Part 1. Acephala and Brachiopoda. 1851. 3s. $6 d$.

Nomenclature of Mollusca. By Dr. W. Baird, F.L.S. \&c.

Part 1. Cyclophoridæ. 1851. 1s. $6 d$.

\section{RADIATA.}

Catalogue of Marine Polyzoa. By G. Busk, F.R.S. \&c., with characters and figures of all the species.

Part 1. Chilostoma. 1852. 17s.

Catalogue of the Echinidæ or Sea Eggs. By Dr. J. E. Gray, F.R.S.

Part 1. Echinida irregularia. 12mo, with Plates.

Containing the characters of all the known genera and species, and illustrated with figures of the new species.

List of British Radiata; with Synonyma. By Dr. J. E. Gray, F.R.S. 1848. $4 s$.

List of British Sponges; with Synonyma. By Dr. J. E. Gray, F.R.S. 1848. $10 d$.

\section{BRITISH ZOOLOGY.}

List of the British Animals; with Synonyma and references to figures.

Part l. Radiata. By Dr. J. E. Gray. 1848. $4 s$.

Part 2. Sponges. By Dr. J. E. Gray. 1848. $10 d$.

Part 3. Birds. By G. R. GraY. 1850. 4s.

Part 4. Crustacea. By A. White. 1850. 2s. $6 d$.

Part 5. Lepidoptera. By J. F. Stephens. 1850. $5 s$.

Part 6. Hymenoptera. By F. Sмiтh. 1851. $2 s$.

Part 7. Mollusca Acephala and Brachiopoda. By Dr. J. E. Gray. 1851. 3s. 6d.

Part 8. Fish. By A. White. 1851. $3 s$.

Part 9. Eggs of British Birds. By G. R. Gray. 1852. $2 s .6 d$.

Part 10. Lepidoptera (continued). By J. F. Stephens. 1852. $2 s$.

Part 11. Anoplura or Parasitic Insects. By H. Denny. $1 s$. Part 12. Lepidoptera (continued). By J. F. Stephens. 1852. $9 d$.

Part 13. Nomenclature of Hymenoptera. By F. Sмгтн. 1853. $1 s .8 d$.

Part 14. Nomenclature of Neuroptera. By A. White. 1853.

N.B.-These Catalogues can be obtained at the Secretary's Office in the British Museum ; of Messrs. Longman \& Co. ; or of any Bookseller. 
hathlda Alexonde

\section{CATALOGUE}

- or

\section{MARINE POLYZOA}

IN

THE COLLECTION

OF THE

BRITISH MUSEUM.

PART I.

CHEILOSTOMATA (PART).

LONDON :

PRINTED BY ORDER OF THE TRUSTEES.

1852. 


$$
\text { Mip. Leg and 2mi }
$$




\section{NOTICE.}

In the present Catalogue it is intended to comprise figures and descriptions of all the species of Marine Polyzoa in the Collection of the British Museum, - and from typical specimens therein contained.

This Collection, already valuable, especially in the possession of Dr. Johnston's specimens, has recently been materially augmented by the addition of numerous Australian and other forms, many of them new, procured by Mr. J. M'Gillivray, on the Voyage of H.M.S. Rattlesnake. It has also been much enriched by the liberality of Charles Darwin, Esq., F.R.S., Dr. J. Hooker, F.R.S., Dr. Lyall, R. M'Andrew, Esq., F.R.S., J. S. Bowerbank, Esq., F.R.S., the late W. Thompson, Esq., of Belfast, and others, who have placed their Collections at Mr. Busk's disposal, for the purposes of this Catalogue, and for the selection of the specimens required for the Museum Collection.

The Catalogue has been prepared, and the drawings made, by Mr. George Busk, F.R.S., who has also super- 


\section{iv}

intended the execution of the lithography. The magnified figures have in all cases been taken from nature, and for the most part from specimens preserved in fluid, in order to ensure a more natural aspect than that afforded by dried specimens. As they have been drawn with the aid of the camera lucida, and to a scale which is given with each plate or figure, the absolute and relative proportions of the different objects will be at once obvious.

The other Parts will appear as soon as they can be prepared.

JOHN EDWARD GRAY.

British Museum,

August 1, 1852. 


\section{LIST OF SPECIES.}

Class POLYZOA ....................................... Page

Order I. P. Infundibulata $\ldots \ldots \ldots \ldots \ldots \ldots \ldots \ldots \ldots \ldots \ldots . . \ldots \ldots$

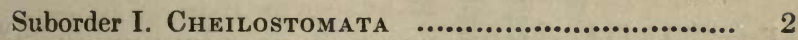

\$1. Articulata .............................................. 2

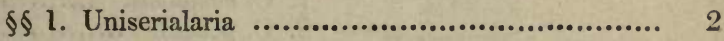

Family 1. Catenicellid a $\quad$................................. 2

Gen. 1. Catenicella .......................... 3

๙. Fenestratæ. 1. C. lorica................. 6

2. C. ventricosa ......... 7

3. C. hastata ............ 7

4. C. aurita (............ 8

5. C. amphora …..... 8

6. C. plagiostoma ....... 8

7. C. cribraria (.......... 9

8. C. margaritacea...... 9

B. Vittatæ. 9. C. formosa ......... 9

10. C. perforata ......... 10

11. C. ringens ............ 10

12. C. elegans ............ 10

13. C. cornuta ............. 11

14. C. umbonata ......... 11

15. C. gibbosa ............ 12

16. C. taurina ............ 12

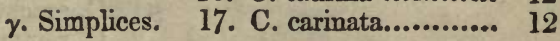

Gen. 2. Alysidium .............................. 14

1. A. parasiticum ...... 14

2. A. lafontii ............ 14 
Gen. 3. Calpidium........................... Page 14

1. C. ornatum

$\$ \S 2$. Bi-multiserialaria ............................. 15

Fam. 2. Salicornariad

Gen. 1. Salicornaria ....................... 16

1. S. farciminoides ........ 16

2. S. gracilis............... 17

3. S. tenuirostris $\ldots \ldots \ldots \ldots, 17$

4. S. malvinensis ........... 18

Gen. 2. Nellia ............................ 18

1. N. oculata $\ldots . . . \ldots \ldots \ldots . .618$

2. N. simplex ............ 19

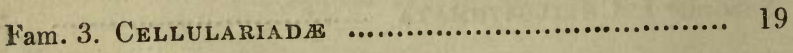

Gen. 1. Cellularia ............................ 19

1. C. cuspidata

2. C. peachii

3. C. ornata ............... 20

Gen. 2. Menipea .......................... 20

1. M. fuegensis $\ldots . . . \ldots . . .21$

2. M. ternata ............. 21

3. M. cirrata................ 21

4. M. triseriata............. 22

5. M. multiseriata $\ldots . . . . .22$

6. M. patagonica ........... 22

Gen. 3. Scrupocellaria ...................... 23

1. S. cervicornis .......... 24

2. S. diadema ............. 24

3. S. scrupea ............. 24

4. S. macandrei............. 24

5. S. cyclostoma .......... 24

6. S. ferox ............... 25

7. S. scruposa $\ldots . . \ldots \ldots \ldots . . .25$

Gen. 4. Canda

1. C. arachnoides........... 26

2. C. reptans

Gen. 5. Emma .............................. 27

1. E. crystallina $\ldots . \ldots \ldots \ldots . .28$

2. E. tricellata ............. 28 
\$2. Inarticulata seu continua

\$ 1. Uniserialaria.

Fam. 4. Scrupariad

28

Gen. J. Scruparia ............................ 28

1. S. chelata................ 29

Gen. 2. Hippothoa .......................... 29

1. H. catenularia ......... 29

2. H. divaricata ........... 30

3. H. patagonica............ 30

Gen. 3. Etea.................................. 30

1. 2 . anguina .............. 31

2. Æ. dilatata .............. 31

3. E. ligulata .............. 31

4. E. truncata.............. 31

Gen. 4. Beania ............................... 32

1. B. mirabilis ............. 32

2. B. australis ............. 32

Fam. 5. Farciminariad a $\quad$................................ 32

Gen. 1. Farciminaria......................... 32

1. F. aculeata .............. 33

Fam. 6. Gemellariad a... ............................... 33

Gen. 1. Gemellaria .......................... 34

1. G. loricata ............. 34

Gen. 2. Didymia ........................... 35

1. D. simplex …........... 35

Gen. 3. Dimetopia .......................... 35

1. D. spicata................. 35

2. D. cornuta ............. 35

Gen. 4. Notamia ............................. 36

1. N. bursaria ............... 36

Fam. 7. Cabereadea ..................................... 37

Gen. 1. Caberea ................................ 37

1. C. rudis $\ldots . . \ldots \ldots \ldots \ldots . . . . .38$

2. C. boryi ….............. 38

3. C. hookeri ............... 39

4. C. lata ................... 39 
viii

\section{LIST OF SPECIES.}

Page

Gen. 2. Amastigia ............................ 40

1. A. nuda ............... 40

Fam. 8. Bicellariade ................................... 41

Gen. 1. Bicellaria .............................. 41

1. B. ciliata ............. 41

2. B. gracilis …....... 42

3. B. grandis $\ldots . . . \ldots \ldots . .42$

4. B. tuba ................ 42

Gen. 2. Halophila ............................. 43

1. H. johnstoniæ......... 43

Gen. 3. Bugula .............................. 43

1. B. neritina ........... 43

2. B. flabellata........... 44

3. B. avicularia $\ldots . . . . . .445$

4. B. plumosa ........... 45

5. B. dentata ........... 46

6. B. murrayana ........ 46

Fam. 9. Flustrade ..................................... 46

Gen. 1. Flustra ............................. 47

1. F. foliacea …....... 47

2. F. papyracea ......... 48

3. F. truncata $\ldots \ldots \ldots \ldots . . .48$

4. F. octodon ........... 49

5. F. denticulata ......... 49

Gen. 2. Carbasea ............................. 50

1. C. papyrea ........... 50

2. C. pisciformis ......... 50

3. C. armata $\ldots . . . \ldots . . .50$

4. C. cribriformis......... 51

5. C. dissimilis $\ldots . . . \ldots .51$

6. C. episcopalis ......... 52

7. C. bombycina ........ 52

8. C. ovoidea ............ 52

9. C. elegans ............ 53

10. C. indivisa ........... 53

Gen. 3. Diachoris ............................. 53

1. D. crotali .............. 54

2. D. magellanica ...... 54

3. D. inermis .......... 54 


\section{CATALOGUE}

\section{OF \\ M A RIN E POLYZOA.}

\section{Class POLYZOA.}

Polyzoa, J. V. Thompson, Zool. Research. Mem. ₹. 92 (1830); J. E. Gray, Syn. Brit. Mus. 133 ; Johnst. Hist. Brit. Zooph. ed. 2. 253.

Bryozoa, Ehrenberg, Symbola Physica (1831); Corall. des Roth. Meer. 153; Jones, Anim. Kingd. 107, 117; Owen, Lect. 93, 101.

Molluscan Zoophytes s. Zoophyta Ascidioida, Johnst. Mag. Zool. \&. Bot. i. 448; Couch, Corn. Faun. iii. 84.

Les Bryozoaires, Audouin and Milne-Edwards, Lam. Anim. s. Vert. ed. 2. ii. 104.

Ciliobrachiata, Farre, Phil. Trans. 1837.

Polypes tuniciens, M. Edwards, Mem. 16.

Polypiaria (pars), Blainv. Dict. Sci. Nat. 1830, lx. 364.

\section{Order I. POLYZOA INFUNDIBULATA.}

Polypiaria infundibulata, P. Gervais, Ann. d. Sc. Nat. (1837) vii. 79. 


\section{Suborder I. Cheilostomata.}

Aperture of the cell filled with a thin membranaceous or calcareous velum, with a crescentic mouth provided with a moveable lip.

Escharadæ, Flustradæ, Cellariadæ (ex Crisia), Fleming, Brit. Anim. 1828.

Polypiaria operculifera et cellariæa (ex Crisia), Blainville, 1834. Escharina, Celleporina, Ehrenb. 1834.

Cheilostomata, Busk, in Voy. of Rattlesn. i. 346, 1852.

Synopsis of Families.

Suborder I. Cheilostomata.

A. Articulata.

a. Uniserialaria.

Fam. 1. Catenicellidæ, p. 3.

b. Bi-multiserialaria.

Fam. 2. Salicornariadæ, p. 15.

Fam. 3. Cellulariadæ, p. 19.

B. Inarticulata seu continua.

a. Uniserialaria.

Fam. 4. Scrupariadæ, p. 28.

b. Bi-multiserialaria.

Fam. 5. Farciminariadx, p. 32.

Fam. 6. Gemellariadx, p. 33.

Fam. 7. Cabereadæ, p. 37.

Fam. 8. Bicellariadæ, p. 41.

Fam. 9. Flustradx, p. 46.

Fam. 10. Membraniporidx.

Fam. 11. Celleporidæ.

Fam. 12. Escharadx.

Fam. 13. Vinculariadx.

Fam. 14. Selenariadx.

$\$ 1$ Articulata. Polyzoary divided into distinct portions or joints by flexible articulations.

\$1. Uniserialaria. Cells disposed in a single series. 
Fam. 1. Catenicellide.

Cells connected by flexible joints.

Catenicellidx, Busk, Voy. of Rattlesn.i. 352.

Synopsis of Genera.

1. Catenicella.

2. Alysidium.

3. Calpidium.

1. Catenicella.

Cells arising one from the upper and back part of another by a short corneous tube, all facing the same way, and forming dichotomously divided branches, of an erect phytoid polyzoary ; cell at each bifurcation geminate; each cell with two lateral processes usually supporting an avicularium. Ovicells either subglobose and terminal, or galeriform, and placed below the opening of a cell in front.

Catenicella, p., Blainville, Man. d'Act.

Catenaria, Savigny, Egypt. pl. 13.

It is much to be regretted that no observations have hitherto been made upon the living animal in this genus, which might almost be regarded as the type of the suborder to which it bclongs ; and it is to be hoped that future observers, in the Australian seas, will make the various species of Catenicella the subject of assiduous study. Considerable light will thence be derived as to the nature and relations of the Polyzoa, thus studied in their simplest, but at the same time perhaps most perfect form.

The genus may be regarded as characteristic of the Australian seas; for although it occurs elsewhere in the southern hemisphere, it does so but rarely, and it is almost unknown in the northern hemisphere. Of the seventeen species enumerated below, thirteen were collected on the coasts of Australia and New Guinen, on the royage of H.M.S. Rattlesnake. Several of these, and some other species which do not occur in the Rattlesnake collection, are found in New Zealand and Campbell's Island. Two or three other species, one at least common to Australia, occur in South Africa.

A species, undoubtedly referrible to this genus, is figured by Savigny (Egypt, pl. 13. fig. 1) under the name of Catenaria, and described by Audouin under that of Eucratea contei. The characters, however, given of this species, either in the figure or description, are insufficient for its exact determination among such a number of forms, greatly resembling each other in general aspect : and although the Cellaria catenulata of Lamarck ( $\mathrm{An}$. 
s. Vert. t. ii. p. 180) is equally an indisputable member of the same genus, its identification, from the description there given, with any of the species here enumerated, does not appear to be possible. There seems little reason for referring his Cell.vesiculosa to the genus at all, as in that species, it is said, the articulations appear to be formed of two cells united. The Menipea hyalaa of Lamouroux (Polyp. Flex.p. 146. pl. 3. fig. 1), though in the figure exhibiting some faint traces of the aspect of a Catenicella, cannot safely be referred to that genus ; neither, most probably, can Eucratea cordierii, Audouin (Savigny, Egypt, p. 13. fig. 3), which latter would seem to form the type of an as yet undescribed genus. In Catenicella each cell arises from the upper and back part of another by a short corneous, tube, which is prolonged from the interior of one cell to that of the one above. The cell is furnished on each side at the top with a usually well-developed avicularium, in some species of huge size, and in some very minute or entirely aborted. This avicularian process, which is sometimes closed above and more or less elongated upwards, constituting a conical or acerose spine, is sometimes open above, assuming the form of a shallow cup or receptacle. In some species both modifications of this portion of the lateral process are met with in the same specimen. This form of spine or cup, as the case may be, is always distinctly separated from the cavity of the avicularium itself by a calcareous septum. Below the avicularium there is also in many cases a third distinct cavity, usually widely open, the opening being occasionally covered in by a convex transparent membrane, and its bottom apparently perforated by several minute foramina. It is thus correct to say, that each cell is furnished with two lateral processes, each of which, in the fully developed state, consists of three distinct compartments, one superior, a cup or spine; a middle one, which is the avicu. larium; and an inferior. And it would appear that one or more of these elementary compartments of the lateral process may be more developed than the next, or sometimes more or less completely aborted. The mouth of the cell is situated at the upper part, and is of the same conformation as in the rest of the Cheilostomatous suborder. An important generic character consists in the gemination of the cell at each bifurcation.

These characters are common to all the species included in the genus, which furthermore admits of being subdivided into three extremely natural sections or subgenera. These subdivisions are named respectively the "Fenestratæ," the "Vittatæ," and the "Simplices." In the ferrestrate division the cells are of larger size and strunger than in the others, and the wall of the cell appears to be constituted of at least two distinct laminæ. The external lamina on the front of the cell is perforated by a certain 
number of holes, or rather is wanting in a certain number of spaces, for which spaces the term "fenestræ" is here employed. These apparent openings, therefore, do not penetrate into the eavity of the cell. But besides the fenestræ, there is in some cases a small central opening which does penetrate through the wall. In most cases the fenestræ are arranged in a crescentic, or rather horseshoe-shaped line, indicative as it were of the limits of a regular oval space in the front wall of the cell, the upper part of which oval would be formed by the mouth, and the remainder filled up by the deposition of calcareous matter, as happens in the older cells of many other of the Cheilostumata.

A further characteristic of the fenestrate Catenicelle is the terminal position of the ovicells. These organs are clearly transformed cells, or cells dilated to considerably more than their natural bulk, and assuming a subglobose form; and, what is worthy of remark, these terminal ovicells always have a sessile avicularium on the summit.

In the "Vittatx" the cell is smaller, and usually more delicate and transparent. They probably want the outer lamina, or have it very thin, and consequently present no fenestrate spaces, and the front of the cell is beset (sometimes very sparingly) with more or less prominent, minute, acuminate "papillæ." On each side, sometimes on the anterior aspect, sometimes quite laterally, is a narrow elongated band, or "vitta" as it is here designated, from which the sectional appellation is derived. This band or stripe (the nature of which is unknown) varies in width and proportionate length and position in different species; it is slightly elevated, and marked with larger or smaller circular, discoid, or acuminated eminences. This subdivision is further distinguished by the situation of the ovicells, which are not terminal, but occur at irregular intervals on cells in the course of the series. They are of the ordinary galeate form, but are not apparently piaced above the mouth of a cell, as is most usual in the Cheilostomata, but below it in front. In all cases the shape of the ovicelligerous cell is very different from the rest, and in all the vittate species it arises from its predecessor, without the intervention of a short tube, but is immediately sessile upon it by a broad base. This conformation is well seen in C. gibbosa (Pl. VII. figs. 3,4$)$. It is not improbable, however, that the inferior position of the ovicell is more apparent than real, and that in fact the ovicell, which appears to be inferior in the upper of the two cells, really belongs to the one below, and is merely, as it were, immersed in the base of the upper one. In one instance, C.taurina (Pl. XI. fig. 3), the situation of the ovicell is peculiar: in this species the ovicelligerous cell is geminate, the ovicell being placed on the summit of a secondary cell, on the side of the one forming part of the series. 
In the third subdivision of the Catenicella, or that here termed "Simplices," there is at present but one species. This differs so much in many respects from any of the former, that it might, perhaps, constitute the type of a distinct genus : agreeing however as it does, in essential particulars, with the rest, it has been thought better to place it, at least provisionally, with them. In this form there are neither "fenestræ" nor "vittæ," nor are there, properly speaking, any avicularia. The latter, however, are represented by two strong lateral processes, which are grooved in front, and may in the living state have a moveable member, either mandible or seta, which is wanting in the dead specimens.

a. Fenestratæ. Cells fenestrate in front; ovicells terminal.

Catenicellæ fenestratæ, Busk, in Macgillivray's Voy. Rattlesn. i. 352.

\section{Catenicella rorica. Pl. I.}

Cells elongated rhomboidal, truncate at each end. Fenestra 3, large, the lowest the largest. Avicularia large and strong; back marked with faint longitudinal striæ.

Catenicella lorica, Busk, in Voy. of Rattlesn. i. 358. Hab. Bass' Strait, 45 fathoms.

Colour white, transparent. A fine, widely-branching species, in which the catenulate aspect is more evident to the eye than in almost any other. It is at once recognizable by the rhomboidal, scutate form of the cell, viewed anteriorly; and when the back is also viewed, the resemblance of the two aspects to the back, and breast-plates of a coat of mail, is very striking. The structure of the lateral processes is more distinctly to be made out in this species than in any other. Each lateral process consists,-1. of a deep cup-like cavity above; 2 . a middle compartment-the avicularium; and 3. a third loculament below the avicularium, the wide opening of which is covered in by a convex transparent membrane. The bottom of this loculament appears to be perforated; and it is to be noticed also, that there is a small central perforation in the septum separating it from the cavity of the avicularium. Towards the bottom of the cell, on each side, is a welldeveloped lateral area, of exactly the same conformation as the subavicularian loculament, and like it covered in by a convex transparent membrane. It might be supposed that these cavities were for the purpose of containing air, in order to render the otherwise heavy branches of the polyzoary buoyant. They at all events appear to be perfectly empty. 
2. Catenicella ventricosa. Pl. II. figs. 1, 2; Pl. III. figs. $1,2,3,4,5$.

Cells oval, compressed. Avicularia wide, supporting sometimes a cuplike cavity, sometimes a closed, broad, conical spine. Fenestræ 7 , with fissures radiating towards a rounded central pore. Front of cell studded with minute acuminate papillæ; back smooth, sometimes spotted.

Catenicella ventricosa, Busk, in Voy. of Rattlesn. i. 357. t. 1. fig. 1. $H a b$. Bass' Strait, 45 fathoms.

Colour dirty white or brown; habit stiff ; stem strong, straight ; branches short and crowded; probably attains a height of 4 or 5 inches. The only other species with which it can be confounded is $C$. amphora, from which it differs in the greater size and more irregular form of the lateral processes ; in the presence of the minute papillæ on the surface; and in the absence of the narrow longitudinal band on the back; instead of which, the older cells in C. ventricosa exhibit a sort of broad scutum, almost covering the back of the cell, and sending off two lateral bands on the sides of the cell, one passing below the avicularium and above the lateral area, and the other towards the acuminated apex of the avicularium. It also wants the raised bands which in C. amphora pass from the sides of the mouth to the apex of the avicularium in front. One large specimen presents a variety worthy of note: in this the backs of all the cells, except one here and there, exhibit (internally?) numerous irregular-sized leopard-like spots.

\section{Catenicella hastata. Pl. II. figs. 3,4 .}

Cells oval. Fenestræ 7-9, disposed in a crescent, with fissures radiating towards the median line. Avicularia supporting large, pyramidal, pointed, hollow processes, compressed, and perforated, before and behind, by five or six small circular pores.

Catenicella hastata, Busk, in Voy. of Rattlesn. i. 355.

C. bicuspis? Gray, Dieffenbach's New Zealand, ii. 293.

Hab. Bass' Strait, 45 fathoms. New Zealand.

Of a yellowish white colour, sometimes reddish. Forms fine bushy tufts, with long wavy branches, arising from a short common stem, and attaining a height of 5 or 6 inches. It appears sometimes to be parasitic upon other Polyzoa, and is then much smaller. Its peculiar characteristics are, the perforated and striated scutiform area on the front of the cell, and the perforated or apparently perforated pyramidal lateral processes above each avicularium. 
4. Catenicella aurita. Pl. IV. figs. 1, 2, 3.

Cells oval or subglobose. Avicularia large and strong, two blunt processes, the upper the longer, on each side of the opening in front. Fenestræ 5 , around a central one.

Hab. New Zealand. Cook's Straits, Lyall; Campbell's Island, Hooker.

\section{Catenicella amphora. Pl. IV. figs. 4, 5 .}

Cells oval, sides rendered straight upwards by the wide avicularia, which are prolonged above into an acute spinous process, and support a shallow cup. Fenestræ 9 , pyriform, an oval central perforation; an elevated band extending from the sides of the aperture to the upper angular processes of the avicularia; an elevated flattened band, along the middle of the back, branching off above to each avicularium.

Catenicella amphora, Busk, Voy. of Rattlesn. i. 356.

Cellaria catenulata? var. B., Lamarck, An. s. V. ii. 180 (2nd ed.). Hab. Bass' Strait, 45 fathoms.

Of a bright reddish brown colour, and in the younger cells very transparent. Forms small irregularly branched bushes, 4 to 6 inches high and wide. It is peculiar by its extremely regular vase-like form of cell, which is given by the continuation upwards of the broad avicularia in nearly a straight line, and their prolongation into a sharp angular spine, on the inner side of which is a shallow cup-like cavity, whose sides are usually more horny than calcareous. The number of fenestræ appears to be very constant.

The length of the branches before their dividing, and their straightness, together with the colour of this species, render it not improbable that it is the form intended by Lamarck (l.c.).

6. Catenicella plagiostoma. Pl. V. figs. 1, 2 .

Cells short, ovoid. Avicularia nearly as long as the cell, terminating in an acute spinous point, and supporting a deep cupped cavity above; aperture placed obliquely; front of cell divided into five large subtriangular fenestra by four broad bands. Back of cell with a broad central band and two narrower bands branching from it on each side; surface of spaces left uncovered by the dorsal bands beset with setose spines.

Catenicella plagiostoma, Busk, Voy. of Rattlesn. i. 358.

Hab. Bass' Strait, 45 fathoms. Swan Island, Banks' Strait.

Colour brownish white; habit stiff ; branches short. This species is at once recognizable by the peculiar oblique position of 
the mouth, the enormously developed avicularium, usually only on one side of the cell, and by the sculpture of the cell, which appears as if it were swathed with broad tapes or bands. The wide spaces left between the bands in front clearly represent the true nature of the fenestræ of other species. It is the only species furmished with elongated setose spines.

7. Catenicella cribraria. PI. V. figs. 3, 4.

Cells subglobular, compressed, more or less alate. Avicularia large, without any superior appendage, and prolonged downwards into elevated lateral alæ. Fenestræ numerous, small, round, equidistant, the circumferential being larger than the rest: a minute central crescentic pore.

Catenicella cribraria, Busk, Voy. of Rattlesn. i. 359. Hab. Bass' Strait, Hooker, 45 fathoms. Cook's Strait, New Zealand, Lyall.

Colour brown, loosely branched, and several inches high. Distinguished readily by the cribriform aspect of the front of the cell, by the curiously formed central orifice, and by the absence of any superior appendage to the avicularium.

8. Catenicella margaritacea. Pl. VI. figs. 1, 2, 3.

Cells oval or subglobular, much compressed. Avicularia short and broad, supporting a deep cuplike cavity. Fenestræe 5, large. Lower margin of aperture notched in the middle; back of cell minutely sulcate; sulci short, interrupted, irregular.

Catenicella margaritacea, Busk, Voy. of Rattlesn. i. 356. Cellaria vesiculosa?, Lamk. An. s. V. ii. 190.

Hab. Swan Island. Banks' Strait. New Zealand, Lyall.

A very beautiful species, the branches resembling strings of minute pearls. The pearly lustre (in the dry state) owing without doubt to the minute sulci on the backs of the cells. These sulci are not, however, consequent upon the drying, because they are equally apparent and constant when the specimen has been immersed in fluid. The species may almost at once be distinguished by the notch in the lower margin of the mouth, and which notch represents the central suboral opening present in some other species.

$\beta$. Vittatx. Cells furnished with a narrow elongated bund or "vitta" on each side. Without fenestra. Ovicells galeriform, not terminal.

9. Catenicella formosa. Pl. VII. figs. 1, 2.

Cells oval. Aricularia large, flat, or cupped above. Vitta

B 5 
elliptical, sublateral. Surface in front covered with minute acuminate papillæ.

Catenicella formosa, Busk, Voy. of Rattlesn. i. 360. $H a b$. Swan Island, Banks' Strait.

Colour light plumbeous. Parasitic upon C. margaritacea. The cells are the largest of any in the vittate division, and very regular and uniform in size and outline. The more distinctive characters are taken from the comparatively broad vittæ, and the flat or cupped upper surface of the avicularia, which are usually continued downwards into a prominent ridge or ala.

10. Catenicella perforata. Pl. ViII. figs. 1,2 .

Cells elongated oval. Avicularian processes large, perforated at the base or by several openings. Vittre long, wider below, lateral. Surface in front papillose.

Hab. New Zealand, Hooker, Lyall, Darwin. Tasmania, Hooker.

11. Catenicella Ringens. Pl. Vili. figs. 3,4 .

Cells ovoid or subglobular. Avicularia usually very unequal, the larger one gaping. Vittæ, anterior, broad. Surface in front smooth.

Hab. New Zealand, Dieffenbach. Algoa Bay.

Differs from C. elegans, with some forms of which it might be confounded, in the absence of acuminate papillæ on the anterior surface, and in the comparatively greater size and peculiar gaping aspect of the avicularia, or not unfrequently of one of them.

\section{Catenicella elgans. Pl. IX.}

Cells elongated, ovoid. Avicularia large and projecting, without any superior appendage. Vittæ narrow, sublateral. Surface in front papillose.

? Eucratea Contei, Audouin, Expl. i. 242 ; Savig. Eg. pl. 13. f. 1. Catenicella Savignyi?, Blainv. Man. d'Act. 462. pl.78. f. 1. Catenicella elegans, Busk, Voy of Rattlesn. i. 361. t. 1. f. 2. Hab. Bass' Strait, 47 fathoms; Port Cooper, Banks' Peninsula; Algoa Bay; Port Dalrymple.

A delicate and beautiful parasitic species; the branches slender and spreading; colour white and very transparent; cells regular, and uniform in size and shape. There appears to be little or no difference between the Australian and South African species; in the latter, however, the vittæ are usually much longer, extending upwards as high as the mouth. 


\section{Catenicella connuta. Pl. X. figs. $1,2,3$.}

Cells oval. Avicularia in most cells wholly transformed into long pointed retrocedent spines, on one or both sides; in others into shurter spines, or unaltered. Vittæ linear, extremely narrow, lateral, and extending the whole length of the cell from the base of the avicularium. Surface in front smooth.

Catenicella cornuta, Busk, Voy. of Rattlesn. i. 361. Hab. Bass' Strait, 45 fathoms.

Colour yellowish white; growth small; parasitic upon C. amphora. As some difficulty might be experienced in the discrimination of this species from $C$. elegans and another South African species ( $C$. taurina), it is requisite to remark that the long retrocedent spines, when present, are not placed upon or superadded to the avicularia, but that they seem to represent an aborted or transformed state of those organs. They vary much in length and size in different cells, and even in those of the same branch, as it frequently happens that there is a spine, usually of diminutive size, on one side, and a very large avicularium on the other; sometimes (but rarely) an avicularium of more moderate size on both sides. But the character of the species by which it is more particularly distinguished, consists in the presence on a great many cells, in one part or other of the polyzoary, of the two long and strong spines projecting backwards.

\section{Catenicella umbonata. Pl. X. figs. 4,5 .}

Cells more or less pyriform, narrow below, bulging or ventricose above. Avicularia large and strong. Vittæ strap-shaped, anterior, extending from the level of the mouth to the bottom of the cell, with acuminate papillæ. A broad compressed projecting process on the middle of the back. Surface in front papillose.

Catenicella umbonata, Busk, Voy. of Rattlesn. i. 362. $H a b$. Bass' Strait, 45 fathoms.

The cells in this species are small, inflated or ventricose, and, as it were, subglobular above, becoming much attenuated below; but the cavity of the cell does not appear to extend into this contracted portion, in which is contained the connecting tube, strengthened by calcareous matter, the inferior continuation of the lateral alx, which descend from the base of the avicularium. Owing to the large size of the avicularia the upper part of the cell is much widened, and the whole acquires somewhat of a triangular form, and has a peculiar rugose aspect; derived in part also from the large size and elevation of the acuminated papillæ, 
not only of the vittæ, but on the surface of the cell itself. The central umbo or crest posteriorly is a marked feature.

\section{Catenicella gibbosa. Pl. VII. figs. 3,4 .}

Cells pyriform, ventricose posteriorly, mach attenuated downwards. Avicularia small, placed in front close to the side of the aperture, at the base of strong conical pointed processes which project in front, and are connected across the top of the cell by a prominent toothed ridge. Vittæ long, linear, entirely lateral. Surface in front with a few scattered acuminate papillæ.

Catenicella gibbosa, Busk, Voy. of Rattlesn. i. 360. Hab. Prince of Wales Channel, Torres' Strait, 9 fathoms, mud.

Of a dark lead colour when dry. Forms an elegantly-branched bush, about 2 inches high. The gibbous form of the cells, and the peculiar anterior position of the avicularia, at the base of the projecting lateral processes, at once distinguish it from all the other vittate species. The toothed (sometimes entire) ridge extending between the two lateral processes across the top of the cell and overlapping the mouth like a penthouse, is also a very peculiar feature.

\section{Catenicella taurina, n. sp. Pl. XI.}

Cells oval or subglobose. Avicularia large and strong, frequently transformed into long and large ascending (not retrocedent) spines. Surface of cell smooth. Vittæ small, inconspicuous, lateral. Surface in front smooth. Ovicelligerous cells geminate. Hab. Algoa Bay, \&c., South Africa.

This species is at once distinguishable by the peculiarity in the conformation of the ovicelligerous cells, and the spines, which are as long as in C. cornuta, are not retrocedent as in that species, but ascend directly. The habit of the polyzoary is also very peculiar, growing in long branching tufts, and the smaller branchlets composed of the cells arise in pretty regular whorls around the central stems; giving to the whole somewhat of the aspect of Thuiaria thuja.

\section{$\gamma$. Simplices. Without vitta or fenestra.}

Catenicellæ simplices, Busk, Voy. of Rattlesn. i. 363.

17. Catenicella carinata. Pl. VI. figs. 4, 5, 6 .

Cells oval, narrowed at each end; lateral processes (without. avicularia?) projecting horizontally outwards from the side of the aperture, which is nearly central. Mouth with a small tooth on each side, and below it a triangular space with three strong coni- 
cal eminences. A few scattered papilla on the surface of the sides and back. Ovicelligerous cells geminate.

Catenicella carinata, Busk, Voy. of Rattlesn. i. 363.

Hab. Bass' Strait, 45 fathoms.

This remarkable form differs so widely in many respects from any of its congeners, as almost to deserve to be considered as the type of a distinct subgenus. The lateral processes, which may be taken to represent the perfect avicularia of the other species, are, as far as can be ascertained from specimens that have been dried, without a moveable mandible, and are probably really so because there is no corresponding beak. These processes are channelled in front nearly from the base to the extremity; they arise by a broad base on each side of the mouth and on the front of the cell, and from the conjoined bases is continued upwards and downwards, or to the top and bottom of the cell, a prominent flattened band. The expanded bases circumscribe an oval space nearly in the centre of the front of the cell, the upper two-thirds of which space are occupied by the circular mouth, on each side of which is a small calcareous tooth, to which apparently are articulated the horns of the semilunar labial cartilage. The lower third is filled up by a yellow horny ? membrane, upon which are placed three conical eminences disposed in a triangular manner. The back of the cell is very convex, and has, running along the middle of it, an elevated crest or keel, acuminate in the middle. The ovicell is situated in front of the cell below the mouth, and below it are three considerable-sized areolated spots, disposed like the three conical spines in a triangle. The cells upon which the ovicells are placed, are always geminate, that is to say, have a smaller cell growing out from one side. It is not improbable that the ovicelligerous cell in fact represents two cells, to the lower one of which the ovicell properly belongs.

\section{Alysidium.}

Cells connected by short corneous tubes, of which two arise from a single cell, at each bifurcation. Avicularia single and anterior, or double and lateral, or altogether wanting?

Alysidium, Busk, MSS.

Closely allied to Catenicella; the difference in the mode in which the branches are given off, appears to afford a sufficient ground for the separation from that genus, of the forms included in the present. It must be stated, however, that there is, except in that respect, but little connection between the two species here somewhat arbitrarily made congenerous, each of which will most probably form the type of a distinct genus. 
1. Alysidium parasiticum, n. sp. Pl. XIV. figs. $6,7,8,9$.

Cells oval, narrow below ; a lateral process on either side above and in front, on the sides of a depressed area, in which the aperture is placed, and in which are two small perforations below the aperture. Ovicelligerous cells, arising by a corneous tube from the front of a cell.

Hab. Algoa Bay, Port Natal, \&c.

A small delicate species, hitherto only observed parasitic upon Carbasea armata; but it appears to be very abundant. The ovicells are very peculiar, and would afford an excellent subject for examination in the living state.

2. Alysidium lafontir. Pl. XIV. figs. 1, 2, 3, 4.

Cells much elongated and tubular below. Aperture superior, margin with spines; a large avicularium in front immediately below the aperture. Front of cell with numerous perforations ; ovicell superior, cucullate.

Eucratea Lafontii, Audouin, Expl. i. 242; Savig. Egypt. pl. 13. f. 2 .

Hab. Coast of Spain, M'Andrew. Mediterranean? Savig.

This species occurs abundantly on a piece of Eschara foliacea, spreading across its hollows like a spider's web. In Savigny's figure it is represented as growing upon a species of Fucus. It is a very curious and remarkable form.

\section{Calpidium.}

Cells with an avicularium on each side; with two or more, usually three, distinct apertures ; arising one from the upper part of another in a linear series, all facing the same way and forming dichotomously divided branches of an erect phytoid polyzoary : cells at the bifurcation single.

Calpidium, Busk, Voy. of Rattlesn. i. 364.

This very peculiar genus is distinguishable from Catenicella in the first place, by the anomalous circumstance that each cell is furnished with two, or more usually with three, distinct keyholeshaped mouths, and is doubtless inhabited by three distinct individuals. Whether these are separated from each other by internal partitions is unknown, but the closest examination of cells, rendered transparent by means of acid, fails to discover such. In cells thus prepared there are apparent, however, three distinct masses, reaching from the bottom of the cell to each orifice, and which are probably the remains either of the body or of the retractor muscles of the animals. 


\section{Calpidium ornatum. Pl. XII., XIII.}

Cells triangular-urn-shaped, compressed, very broad above; upper border straight; mouths 2-3, keyhole-shaped. Five fenestræ below each mouth; numerous branching bands on the back.

Calpidium ornatum, Busk, Voy. of Rattlesn. i. 364. t. 1. f. 3, 4, 5. Hab. Bass' Strait, 45 fathoms.

Cells large, regular, and uniform in size, resembling very closely an antique sculptured urn. Colour dark brown, and the walls so thick as to be nearly opaque. The polyzoary, which appears to attain a height of 4 or 6 inches, is bipinnate (with all the branches on one plane), the branches alternate, and given off with extreme regularity. The ultimate ramules are incurved. The central stem, or series of cells, differs in no repect as regards the size or disposition of the cells composing it, from the branches.

\section{$\oint \oint 2$. Bi-multiserialaria. Cells disposed in a double or multiple series.}

\section{Fam. 2. Salicornariade.}

Cells disposed around an imaginary axis, forming cylindrical branches of a dichotomously divided, erect polyzoary.

Salicornariana, Gray, Brit. Rad. 131.

Synopsis of Genera.

1. Salicornaria.

2. Nellia.

The distinction between the Salicornariadæ, as here constituted, and the Farciminariadx is at first sight not very obvious, but further examination will serve to justify their separation. In the Salicornariadx the branches of the polyzoary constitute distinct articulations connected by flexible joints, whilst in the Farciminariadx the polyzoary is continuous throughout. In the Salicornariadæ moreover the ovicells are deeply immersed, their situation being discernible merely by an alteration in the form of the cells by which they are borne. In the Farciminariadx, on the other hand, the ovicell is external and of the usual cucullate form. The composition of the polyzoary in the Salicornariadæ is calcareous, in the Farciminariadæ corneous. Another family, that of the Vinculariadæ, to be afterwards described, althuugh agreeing with the Salicornariadæ and Farciminariadx in the disposition of the cells around a central imaginary axis, offers sufficient points of difference to justify its distinction from them. 


\section{Salicornaria.}

Front of cell much depressed, surrounded by an elevated ridge, by which the surface is divided into more or less regular rhomboidal or hexagonal spaces; no aperture. Avicularia disposed irregularly.

Salicornaria, Cuv. R. A. 1837 ; Johnst. Brit. Zooph. ed. 2. 355. Farcimia, Flem. Brit. Anim. 534; Johnst. Brit. Zooph. ed. 1.

Cellaria a, Lamk. Syn. 1801, 1812 ; Lamx. 1812; Blainv. 1830.

The distinguishing characteristic of this genus, which consists in the division of the surface of the branches into more or less regular and uniform rhomboidal or hexagonal spaces, is sufficiently obvious in all mature specimens ; but as the form of spaces is in great measure dependent upon the degree of development of the cells, whose fronts the spaces represent, little dependence can be placed upon their mere form as a specific distinction. A better distinction in doubtful cases will be found in an organ which does not appear hitherto to have been noticed in this genus, viz. the avicularium, the form and position of which afford apparently an invariable character as readily discernible and sufficient, as a specific distinction, as does its presence or absence serve with other characters to distinguish Salicornaria from its near ally Nellia.

1. Salicornaria farciminoides. Pl. LXIV. figs. 1, 2, 3 ; Pl. LXV. (bis) fig. 5.

Front of cell rhomboidal, or hexangular with a straight side at top and bottom; sometimes arched above; cells in the same series contiguous. Surface granular. Avicularium distinct from, and above a cell, rostrum immersed, mandible semicircular.

Salicornaria farciminoides, Johnst. Hist. Brit. Zooph. ed. 2. p. 355. t. 66. figs. 6, 7; Gray, Cat. Brit. Rad.

Corallina fistulosa fragilis, Raii Hist. i. 65 .

Corallina fistulosa fragilis, internodiis prælongis lævibus, albis, farciminum modo catenatis, Pluken. Phytog. pl. 26 . fig. 2.

Bugle Coralline, Ellis, Corall. 46. no. 1. pl. 23. figs. a, A, B, C. Eschara fistulosa, Linn. Syst. ed. 10.804.

Cellularia Salicornia, Pall. Elench. 61.

Tubularia fistulosa, Linn. Syst. 1302; Oliv. Zool. Adriat. 267; Berk. Syn. i. 214.

Cellaria farciminoides, Ellis and Soland. Zooph. 26.

Isis Hippuris, Fabr. Faun. Grœnl. 427.

Cellaria Salicornia, Lamk. Anim. s. Vert. ii. 135, ed. 2. ii. 176 ; Bosc, Vers, iii. 129. pl. 28. fig. 6; Lamx. Expos. Méthod. 5; Corall. 55 ; Bull. Scc. Phil. iii. 185; Blainv. Act. 455. pl. 77. fig. 1. 
Salicorniaires, Cuv. Règ. Anim. iii. 303.

Salicornaria dichotoma, Schweig. Handb. 428.

Salicornaria fistulosa, Templeton, Mag. Nat. Hist. ix. 469.

Farcimia fistulosa, Flem. Brit. Anim. 534; Johnst. Trans. Newc. Soc. ii. 266.

Cellaria fistulosa, S. V. Wood, Ann. \& Mag. Nat. Hist. xiii. 17. Farcimia Salicornia, Johnst. Brit. Zooph. 295. pl. 37. figs. 6, 7; Couch, Zooph. Cornw. 58 ; Corn. Faun. 129. pl. 20. tig. 3.

Var. $a$. Front of cell rounded, above.

Tubularia fistulosa, Esper, Tubul. t. 2. figs. 1-4.

Farcimia sinuosa, Hassall, Ann. \& Mag. Nat. Hist. vi. 172. pl. 6. figs. 1, 2; Macgilliv. ibid. ix. 468.

Farcimia spathulosa, Hassall, ibid. xi. 112.

Salicornaria sinuosa, Johnst. Brit.Zooph.ed.2.p.356.t.66.fig.8; Gray, Cat. Brit. Rad.

Hab. Seas of Europe; Algoa Bay.

There can be no doubt, after examination of the typical specimens in the British Museum collection, of the identity of $S$. farciminoides and S. sinuosa, Hass. Figs. 1, 2. Pl. LXIV. are drawn from different parts of one and the same specimen.

2. Salicornaria gracilis. Pl. LXIII. fig. 3 ; Pl. LXV. (bis) fig. 2.

Front of cell oval or lanceolate, pointed above and below ; cells in the same series distant. Surface granular. Avicularium replacing a cell; rostrum prominent, cucullate mandible broad triangular.

Cellaria tenella? Lamk. A.s. V.t. ii. p. 177.

Salicornaria punctata, Busk, op. cit. 366. Cellaria Salicornioides? Savigny, Egypt. pl. 6. fig. 7. Hab. Off Cumberland Island; Cape Capricorn.

Parasitic upon Sertularians and Polyzoa; branches slender, straggling, of irregular lengths.

3. Salicornaria tenuirostris. Pl. LXIII. fig. 4.

Front of cell hexagonal, with an angle at top and bottom. Cells in the same series distant, elongated or very short. Surface subgranular. Avicularium replacing a cell ; rostrum prominent, pointed; mandible long, narrow, produced, acute.

Salicornaria bicornis, Busk, op. cit. 366 .

Var. $a$. with the sides of the cell raised into a minute spinous projection at each of the upper lateral angles. Hab. Bass' Strait, 45 fathoms. Tasmania, Hooker. 
Parasitic. Branches shorter and thicker than in the preceding species. In the shape of the area they are much alike, but in $S$. tenuirostris, in some cells, and occasionally throughout the greater part of an internode, the area differs widely from the more usual form. It is much expanded and arched above. In this case there is usually a considerable-sized perforation above the mouth of the cell, as occurs not unfrequently also in $S$. farciminoides. These indicate the situation of the immersed ovicells. The avicularium affords an excellent character between these otherwise not readily distinguishable forms.

4. Salicornaria malvinensis. Pl. LXIIl. figs. 1, 2; Pl. LXV. (bis) fig. 1.

Front of cell arched above, very acute below. Cells distant in the same series. Surface smooth. Avicularium replacing a cell, rostrum immersed, mandible wide, large, triangular, pointed.

Hab. Falkland Islands, S. Patagonia, Darwin.

Readily distinguishable by the perfect smoothness of the surface and uniformly arched form of the area above, as well as by the form of the avicularium.

\section{Nellia.}

Front of cell convex, with a distinct raised border; a large aperture. No avicularia. Ovicells —?

Salicornaria, part., Busk, Voy. of Rattlesn. i. 367.

Nellia, Busk, MSS.

Although evidently closely allied to Salicornaria, this genus would seem to be sufficiently distinct in the form of the front of the cell and in the complete absence of avicularia. The ovicells have not been noticed, and are probably deeply immersed. In the small number of series of the cells and their conformation it approaches the next genus, Cellularia.

1. Nellia oculata. Pl. LXIV. fig. 6; Pl. LXV (bis) fig. 4.

Outline of cell rounded above, not contracted downward, truncate below. Two raised hollow, perforated, papilliform processes below the aperture. Aperture elliptical. Cells quadriserial.

Salicornaria dichotoma, Busk, op. cit. i. 367.

$\mathrm{H} a b$. Prince of Wales Channel, Torres' Strait, 9 fathoms.

Forms small crowded tufts from one to two or three inches high; branches very uniform in length, and thence very regularly forked or dichotomous. 
2. Nellia simplex. Pl. LXV. fig. 1; Pl. LXV. (bis) fig. 3.

Outline of cell rounded above, contracted downwards, truncate below. Margin much raised above. Aperture oval.

Salicornaria marginata, Busk, op. cit. i. 367.

Hab. Prince of Wales Channel, Torres' Strait.

Usually of a greenish colour; but this may be adventitious, although it is general and uniform throughout the specimen. This species differs from the above in being much larger, and in wanting the two perforations on each side above the mouth; in the less comparative size of the aperture, and in the remarkable elevation of the sharp margin surrounding the upper half of the cell. In the looser aggregation and in the form of the cells, it shows the transition from the Salicornariadæ to Cellularia.

\section{Fam. 3. Cellulariade.}

Cells disposed in the same plane, forming linear branches of a dichotomously divided, phytoid, erect polyzoary.

Bugulidæ, part., Gray, Cat. Brit. Rad. B. M. 110. 146.

Cellularidæ, part., Johnst. Brit. Zooph.

Escharidx, part., Johnst. Brit. Zooph. ed. 1. 248, ed. 2. 264; Gray, Syn. Brit. Mus. 1847, 135.

\section{Synopsis of Genera.}

1. Cellularia.

2. Menipea.

3. Scrupocellaria.

4. Canda.

5. Emma.

\section{Celluularia.}

Cells bi-triserial, more than four in each internode; oblong or rhomboidal, contiguous; perforated behind. Without avicularium or vibraculum, unless rarely the former on the upper and outer angle of the cell.

Cellularia, part., Pallas, Elench. Zool.; Fleming, B. A. Cellularia, Busk, MSS. Bugula, part., Gray, List Brit. Rad. B. M. 114.

1. Cellularia cuspidata. Pl. XXVII. figs. 1, 2.

Upper and outer angle prolonged into a strong spine. A single perforation behind. A cuspidate spine on the summit of the median cell at each bifurcation. Ovicell smooth. 
C. monotrypa, Busk, Voy. of Rattlesn. i. 368. Hab. Australian Seas (ubique); New Zealand, Hooker; Lyall.

This is at once distinguished from $C$. peachii by the cuspidate point on the summit of the median cell at each bifurcation, and the smoothness of the surface of the ovicell.

2. Cellularia peachit. Pl. XXVII. figs. 3, 4, 5 .

Cells subelongated, attenuated downwards, truncate and somewhat rounded above. A small spine on the upper and outer angle sometimes wanting. Three to five perforations behind. Mouth oval, regular; margin subincrassate, minutely granular. Ovicell subglobular, with a tessellated surface.

Cellularia Peachii, Busk, Ann. Nat. Hist. New Ser. vii. 82. pl. 8. figs. $1,2,3,4$.

Cellularia neritina, var., Johnst. Brit. Zooph. i. 340, ed. 2. Bugula neritina, var., b, c, d, e, Gray, List Brit. Rad. 114. $H a b$. Britain (north?).

3. Cellularia ornata. Pl. XXVi. figs. 3, 4 .

Cells immersed, nearly square ; front surrounded by a raised line, within which the surface is granular; five to seven minute, scarcely conspicuous perforations behind.

Hab. Algoa Bay.

\section{Menipea.}

Cells oblong, or elongated and attenuated downwards ; imperforate behind, with a sessile avicularium frequently absent on the upper and outer angle, and one or two sessile avicularia on the front of the cell below the aperture.

Menipea, Lamx. Bull. Soc. Philom. 1812, Polyp. Flex.

Cellaria, part., Linn., Solander.

Crisia, part., Lamx. Polyp. Flex. 61.

Tricellaria, Flem.Brit.Anim.540, 1828; Blainv. Man. d'Act.458;

Gray, Brit. Rad. B. M. 113.

The essential character employed to distinguish this genus, is the presence of one or more sessile avicularia on the front of the cells below the aperture, and usually of a sessile avicularium at the upper and outer angle. Although these characters are in themselves artificial, yet the group formed by the aid of them appears to be for the most part pretty natural. With the exception of one or perhaps two species, at present referred to this genus, the Menipea have three or six cells only in each internorle, The branches are consequently loose and straggling, and usually incurved at the extremities, as is best seen in Menipea cirrata. 
In the aberrant species above referred to the cells are numerous in each internode, usually tri- or multiserial. The genus appears to enjoy a wide geographical range, occurring from the arctic circle in a species not here described, to the southern points of South America and of Africa.

a. Operculatæ. Cells with a pedunculate operculum protecting the aperture. Tricellaria.

1. Menipea fuegensis. Pl. XIX.

Cells elongated, three in each internode. Operculum simple, acicular, curred; three to four spines on the upper border. Anterior avicularium single.

Hab. Tierra del Fuego, low water, Darwin; Falkland Islands, Hooker.

2. Menifea ternata. Pl. XX. figs. $3,4,5$.

Cells elongated, much attenuated downwards, three in each internode. Operculum expanded, entire; two spines on the upper margin. Anterior avicularium single.

Cellaria ternata, Ellis and Soland. Zooph. 30.

Sertularia ternata, Turt. Gmel. iv. 687.

Crisia ternata, Lamx. Corall. Flex. 61.

Tricellaria ternata, Flem. Brit. Anim. 540; Blainv. Act. 458; Gray, Brit. Rad. 113.

Cellularia ternata, Johnst. Hist. Brit. Zooph. ed. 2. p. 335. t. 59. Hab. Britain.

B. Inoperculatæ. Without a pedunculate operculum. Menipea.

3. Menipea cirrata. Pl. XX. figs. 1, 2.

Cells pyriform, constricted below, six in each internode, one of the lower usually more or less aborted; usually one large lateral avicularium to each internode; three marginal spines very long and strong; anterior avicularium single, its upper border toothed.

Cellaria cirrata, Ellis and Soland. Zooph. 29. t. 4. fig. d, D. Cellaria crispa, Pall. Elench. Zooph. 71.

Sertularia crispa, Gmel. Syst. Nat. ed. 13. 3860, and

Sertularia cirrata, ib. 3862 .

Tubularia cirrata, Esper, Pf. T. t. 7. fig. 1-3; Seba, Thesau. ii . t. 101. no. 8 .

Menipea cirrata, Lamx. Exposit. p.7.pl. 4. fig. D, D 1; Krauss, Cor. und Zooph. d. Süds. p. 32. $H a b$. South Africa. 
4. Menipea triseriata. Pl. XXili. figs. 2, 3, 4.

Cells oblong, rectangular (behind), bi-triserial, numerous. Aperture oval, pointed below, and there partially filled in by a granulated expansion; one or two marginal spines on each side above. Ovicell rounded, cucullate, smooth; lip of opening entire.

Hab. South Africa.

5. Menipea multiseriata. Pl. LX.

Cells oblong, rectangular, slightly constricted at the waist (behind); multiserial, numerous. Aperture oval, partially filled in by a granulated expansion below; a marginal spine on each side above. Ovicell large, square, with a strong and long, ascending, central umbo in front; the front lip of the opening emarginate; a radical tube inserted into the lower part of each marginal cell behind.

Hab. — ? B. M. (an var. prec.)?

Although here placed under another name, there is perhaps little doubt but that this form is merely a variety of the preceding. The difference in the form of the lower part of the aperture, which in $M$. triseriata is described as pointed, and which in the present species usually appears square or rounded, seems to be owing to the encroachment upon it of the large ovicell. The central umbo in front of that organ, though at first sight a strongly characteristic diagnostic mark, may, as frequently happens, be owing to local conditions. It is a very common thing, especially among the Lepralia, that a boss-like projection of a similar kind should be thrown out on the front of the cell or of the ovicell, and usually upon both; and it is not improbable that the umbo on the ovicell in $M$. multiseriata may be of the same kind,-a protective spine.

\section{Menipea patagonica. Pl. XXIII. fig. 1; Pl. XXV.;} Pl. XXVI. figs. 1, 2.

Cells elongated, slightly narrowed below, six in each internode; mouth oval, simple; a very large and long spine on the upper and outer angle, below which is a sessile avicularium; a single spine on the inner edge of the aperture. Anterior avicularium single, small.

Hab. Falkland Islands, Hooker; Darwin. Port Desire, Patagonia, Darwin.

In Pl. XXV. this species is inadvertently named Cellularia. It is a species very variable in the size and form of the cells, and several figures therefore of its various forms have been given. In 
Pl. XXIII. fig. 1, is shown the mode in which the polyzoary seems to originate in a single cell, which is attached by a corneous tube to some foreign base. And in Pl. XXVI. fig. 2, is shown a curious cup-shaped appendage attached by means of a similar tube to the bottom of a cell.

\section{SCRUTOCELlaAia.}

Cells rhomboidal, with a sinus on the outer and hinder aspect; each furnished with a sessile avicularium at the upper and outer angle, and with a vibraculum placed in the sinus on the outer and lower part behind. Aperture oval or subrotund, spinous above, with or without a pedunculate operculum. Cells biserial and numerous in each internode.

Scrupocellaria, Van Beneden, Recherch. 43; Gray, List of Brit. Rad. B. M. 111.

Bicellaria, sp. Blainv. 1830.

Cellularia, sp. Pallas; Flem.

Cellaria, sp. Soland.; Lamk. 1816.

Scruparia, sp. Oken, Lehrb. Nat. 90, 1816.

This natural genus is characterized more particularly by the presence upon each cell of a sessile avicularium, seated, or in fact forming the upper and outer angle, and of a vibraculum placed on the back of the cell. The cells in some species are provided with a pedunculate operculum, by which it is intended to designate a process, which arising by a short tube from the anterior wall of the cell, immediately beyond the inner margin of the opening, projects forwards and bends over the front of the cell, expanding into a variously-formed limb, and serving as protection to the mouth of the cell in front. The cavity of the tube by which the process arises, becomes, in the expanded portion, continuous with variously disposed grooves or channels which terminate at the edges of the operculum. This organ affords excellent specific characters (not in this genus alone). Besides the sessile avicularia above noticed, many species of this genus also possess avicularia of another kind, and which are placed on the front of the cell below the opening and towards the inner side, or in other words, towards the middle line of the branch. In this genus, in all those species in which the second avicularium occurs, each individual cell is provided with one. This additional avicularium appears to be composed of a flexible material, and it is very easily broken off, so that in many instances, perhaps throughout an entire specimen, the organ itself may be wanting, although its position is clearly evidenced by the existence of a rounded opening in the usual situation of the organ. It is necessary to distinguish this form of flexible (if such it be) avicu- 
larium from the truly articulated and moveable avicularia, in the form of birds' heads, and which form does not occur in the genus Scrupocellaria.

a. Operculatæ. Aperture protected by a pedunculate operculum.

1. Scrupocellaria cervicornis. Pl. LXII.

Operculum large, expanded, marked with channels branching like the horns of a stag. The marginal spine next above the peduncle of the operculum bifurcate.

Scrupocellaria cervicornis, Busk, Voy. of Rattlesn. i. 370. $H a b$. Off Cumberland Island, 25 fathoms.

A small delicate parasitic species, very transparent. The very peculiar markings on the operculum at once distinguish it. The upper margin of the mouth is furnished with five elongated spines, the innermost of which is forked at the extremity.

2. Scrupocellaria diadema. Pl. XXVIII. figs. 1, 2, 3 .

Operculum slightly expanded at the extremity, entire, or obscurely bilobed. A sessile avicularium in front, below the aperture. Ovicell with a single row of four or five openings immediately above the lower border.

Scrupocellaria diadema, Busk, Voy. of Rattlesn. i. 370.

? Acamarchis Bertholletii, Savig. Egypt. pl. 11. fig. 3.

$H a b$. Moreton Bay, $R$.

3. Scrupocellaria scrupea. Pl. XXI. figs, 1,2 .

Operculum reniform, entire ; four to five marginal spines above.

Scrupocellaria scrupea, Busk, Ann. Nat. Hist. 2nd series, vii. 83. pl. 9. figs. 11, 12 .

Hab. Britain (south?).

4. Scrupocellaria macandrei. Pl. XXIV. figs. 1, 2, 3.

Operculum expanded, irregularly reniform, entire. Margin of aperture incrassate, granulose below with a minute spine above and on the outer side, usually absent. Radical tubes toothed.

? Crisia Delilii, Savigny, Egypt. pl. 12. fig. 3.

$H a b$. Coast of Spain, $M^{\bullet}$ Andrew.

B. Inoperculatæ. Without a pedunculate operculum.

5. Scrupocellaria cyclostoma. Pl. XXVIII. figs. 4, 5. A perture subcircular; margin thickened, with three small spines 
above. A large anterior sessile avicularium below the aperture. Ovicell

Scrupocellaria cyclostoma, Busk, Voy. of Rattlesn. i. 370. Hab. Bass' Strait, 45 fathoms.

6. Scrupocellaria perox. Pl. XXII. figs. 1, 2 \& 5 .

Aperture broad, oval, pointed below. Margin rounded, unarmed. An anterior avicularium frequently as wide as the cell below the aperture; external avicularium very small. Ovicell punctured all over.

Scrupocellaria ferox, Busk, Voy. of Rattlesn. i. 370. Hab. Louisiade Archipelago. Bass' Strait.

Distinguished at a glance from the preceding species by the enormous anterior avicularium, which is often nearly as capacious as the cell itself, and would, in the living state, afford an excellent opportunity of investigating the structure and nature of these appendages. The radical tubes in this species, as in S. macandrei, are curiously serrated.

\section{Scrupocellaria scruposa. Pl. XXII. figs. 3, 4.}

Cells subelongate, narrow. Aperture elliptical, with three or four spines above. Ovicell smooth.

Creeping stony Coralline, Ellis, Corall. 38. no. 4. pl. 20. c, C. Celliferous Coralline with angular edges to its cells, Ellis, Phil. Trans. xlviii. pl. 13. no. 7 ; Phil. Trans. abridg. x. 493. fig. 7. $\mathrm{K}, \mathrm{L}$.

Sertularia scruposa, Linn. Syst. 1315; Esper, Pflanz. Sert.t. 15. figs. 1-3; Berk. Syn. i. 220.

Cellularia scruposa, Pall. Elench. 72; Flem. Brit. Anim. 539 ; Couch, Zooph. Cornw. 57 ; Corn. Faun. iii. 126. pl. 23. fig. 2; Reid, Ann. \& Mag. Nat. Hist. xv. 69. \& xvi. 388; Johnst. Hist. Brit. Zooph. ed. 2. 336. t. 58. figs. 5, 6 .

Cellaria scruposa, Ellis and Soland. Zooph. 23; Bosc, Vers, iii. 132. pl. 29. fig. 7 ; Lamk. Anim. s. Vert. ii. 141, ed.2. ii. 192 ; Johnst. Trans. Newc. Soc. ii. 261. pl. 11. fig. 5.

Scruparia scruposa, Oken, Lehrb. Nat. 90.

Crisia scruposa, Lamour. Corall. 60; Templeton, lib. cit. ix. 469. Bicellaria scruposa, Blainv. Act. 459.

Scrupocellaria scruposa, Van Beneden, Recherch. 43 \& 50. pl. 5. figs. 8-16; Busk, Ann. Nat. Hist. 2nd Ser. vï. pl. 9. figs. 8, 9, 10; Gray, List Brit. Rad. B. M. 111.

Hab. Britain. Seas of Europe. 


\section{Canda.}

Cells rhomboidal, sinuated on the outer side for the lodgment of a vibraculum. No avicularium on the upper and outer angle. Canda, Lamx. 1816, Pol. flex.; Blainv. 1830; Gray, List Brit. Rad. B. M. Cellaria, sp. Lamk. 1816.

Cellarina, Van Bened. Bull. Acad. Brux. 1849, 645.

Bicellaria, sp. Blainv. 1830.

Scrupocellaria, Gray, List Brit. Rad. B. M. 112.

This genus is at once distinguished from Scrupocellaria, to which it is otherwise closely allied, by the absence of the sessile avicularium on the upper and outer angle in front, and also by the circumstance, that although there are flexible anterior avicularia, they do not correspond in number with the cells, but seem to be disposed in a suecial tract along the middle of the branch or internode. The connexion of the branches by transverse tubular fibres is not a character of either generic or specific importance, though it is more striking in the only species hitherto known as belonging to this genus than in any other. These transverse tubular fibres are, like the radical fibres in Scrupocellaria, always inserted, not into the body of a cell, but into a vibraculum. They are evidently of the nature of a byssus.

\section{Canda arachnoides. Pl. XXXIII.}

Cells biserial; aperture oval, truncated above, and the upper margin recedent, with a spine on each side, the outer the longer. Surface of cell covered with transparent granulations. An irregular number of sessile avicularia along the median line of each branch. Branches connected by numerous tubular fibres.

Canda arachnoides, Lamx. Exp. Méth. 5. pl. 64. figs. 19-22; Blainv. Man. d'Act. 457.pl. 79. fig. 2 (not Gray, Brit. Rad. 113); Busk, Voy. of Rattlesn. i. 371.

Cellaria filifera, Lamk. An. s. V. 2nd ed. ii. 177.

? Acamarchis Jolloisii, Savig. pl. 11. fig. 2.

Hab. Bass' Strait, 45 fathoms.

2. Canda reptans. Pl. XXI. figs. 3, 4.

Cells constricted below. Aperture oval, with three or four marginal spines and a pedunculate operculum with a lobate lamina.

Creeping Coralline, Ellis, Corall. 37. pl. 20. no. 3. fig. $b$, B. Sertularia reptans, Linn. Syst. 1315; Fabr. Faun. Gronl. 445. Sertularia repens, Berk. Syn. i. 220.

Cellularia reptans, Pall. Elench. 73; Flem. Brit. Anim.; Johnst. 
Brit. Zooph. 291. pl. 38. figs. 3, 4; Couch, Zooph. Cornw. 57 ; Corn. Faun. iii. 127. pl. 23. fig. 3; Reid, Ann. \& Mag. Nat. Hist. xvi. 385; Johnst. Hist. Brit.Zooph. ed. 2. p. 337. t. 58. figs. 3,4 .

Cellaria reptans, Ellis and Soland. Zooph. 23; Lamk. Anim. s.

Vert. ed. 2. ii. 191 ; Johnst. Trans. Newc. Soc. ii. 262. Scruparia reptans, Oken, Lehrb. Nat. 90.

Crisia reptans, Lamour. Corall. 60; Templeton, Mag. Nat. Hist. ix. 469 .

Bicellaria reptans, Blainv. Man. d'Act. 459 ; Cuv. R. A. Ill. t. Acamarchis Geoffroyi, Audouin, Expl. i. 241 ; Savigny, Egypt. pl. 11. fig. 4.

Scrupocellaria reptans, Gray, Brit. Rad. 112.

Hab. Britain (ubique).

\section{Eмma.}

Cells in pairs or triplets. Opening more or less oblique, subtriangular,partially filled up by a granulated calcareous expansion. A sessile avicularium (sometimes absent) on the outer side below the level of the opening.

Emma, Gray, Dieffenb. N. Zealand, ii. 293; Busk, Voy. Rattlesn. 1. 373.

This genus appears to be a natural one, though apparently allied to Tricellaria (Fleming). The more important points of distinction consist in the conformation of the opening of the cell, and in the position of the avicularium when the latter organ is present. The lower half of what would otherwise be the oral opening of the cell is filled up by a thin plate of calcareous matter, granulated on the surface, and by which the actual opening is rendered more or less subtriangular, the mouth being placed just below the apex of the triangle. The margin of the opening is considerably raised, especially at the oral end, so that the opening appears to be situated in a deep depression. This character of opening, however, occurs also in a triserial species of Cellularia from Algoa Bay. The position of the avicularium, entirely below the level of the opening on the outer side of the cell, is the peculiar characteristic of Emma as distinguished from Menipea, in which that organ when present is placed in the upper and outer angle, as in Cellularia proper and Scrupocellaria. It is worthy of notice, that avicularia may be present in every cell in some specimens, and most usually, whilst in others of equal size there will be none at all apparent. So that the position of these organs in this genus, as well as in others, is of more importance systematically than even their existence. 
1. Emma crystallina. Pl. Xl.

Cells in pairs; one, two or three spines on the outer edge, the central usually the longest and strongest.

Emma crystallina, Gray, Dieffenb. New Zealand. ii. 293 ; Busk,

Voy. of Rattlesn. i. 373.

Hab. Bass' Strait, 45 fathoms. New Zealand, Hooker.

Parasitic upon Polyzoa, \&c., circinate, branched; branches irregular, divaricate. The opening of the cell triangular, very obliquely placed.

2. Emma tricellata. Pl. XLI.

Cells in triplets; three or four long spines on the upper and outer part; a small spine on the inner and lower part of the margin of the aperture.

Emma tricellata, Busk, Voy. of Rattlesn. i. 373.

Hab. Bass' Strait. New Zealand, Hooker.

Parasitic upon Catenicella, \&c. Habit long, straggling, very like the preceding species. The cells are more infundibuliform, and the avicularium, which, as in E. crystallina, is not always present, is larger, but occupies the same position on the cell.

$\S 2$. Inarticulata seu continua. Polyzoary continuous throughout.

$\S \S 1$. Uniserialaria. Cells disposed in a single series.

Fam. 4. Scrupariada.

Cells uniserial. Junctions rigid or of the same consistence as the cells. Polyzoary usually loosely adnate.

Crisiadæ (part.), Gray. Syn. Brit. Mus. 1842, 135.

Scupariadæ, Gray, List of Brit. Rad. B. M. 132, 149.

Eucratiadæ, Johnst. B. Z. ed. 2. 288.

Synopsis of Genera.

1. Scruparia.

2. Hippothoa.

3. Atea.

4. Beania.

\section{Scruparia.}

Cells decumbent ; aperture oblique, subterminal: Branches given off from the front of a cell below the aperture.

Scruparia a, Oken, Lehrb. Nat. 90, 1815. 
Eucratea, Johnst. Brit. Zooph. ed. 2. 289.

Eucratea, sp. Lamx. Bull. Soc. Phil. iii. (1812); Flem. 1828.

Unicellaria, sp. Blainv. Dict. Sci. Nat. 1x. (1830).

Scuparia, Gray, Brit. Rad. 132.

1. Scruparia chelata. Pl. XVII. fig. 2.

Cell in the form of a horn. Aperture oblique. Frequently an aborted or rudimentary cell below the aperture in front.

Bull's-horn Coralline, Ellis, Corall. 42. no. 9. pl. 22. fig. b, B.

Sertularia chelata, Linn. Syst. ed. 10.816.

Cellularia chelata, Pall. Elench. 77.

Sertularia loricata, Linn. Syst. 1316; Berk. Syn. i. 220; Esper, Pflanz. Sert. t. 29. figs. 1, 2; Turt. Gmel. iv. 686; Turt. Brit. Faun. 217 ; Stew. Elem. ii. 449.

Cellaria chelata, Ellis and Soland. Zooph. 25 ; Bosc, Vers, ii. 134 ; Lamk. Anim. s. Vert. ii. 140, ed. 2. ii. 189.

Eucratea chelata, Lamx. Bull. Soc. Phil. 1812, ii. 184; Corall. 64. pl. 3. fig. 5 ; Expos. Méthod. 8. pl. 65. fig. 10; Johnst. Hist. Brit. Zooph. ed. 2. 289.

Scruparia chelata, Oken, Lehrb. Nat. 90; Gray, List Brit. Rad. Eucratea loricata, Flem. Brit. Anim. 541.

Eucratée cornée, M.-Edw. Ann. d. Sc. Nat.n.s. ix. 204. pl.8.f.1. Unicellaria chelata, Blainv. Act. 461. pl. 77. fig. 2.

Crisia chelata, Johnst. Brit. Zooph.261; Reid, Ann.\& Mag. Nat. Hist. xvi. 392 ; Couch, Corn. Faun. iii. 98. pl. 18. fig. 1. Hab. Europe; Australia.

\section{HippothoA.}

Cells decumbent, adherent; branches given off from the sides of the cells.

Hippothoa, Lamx. Exp. Méth. 82, 1821 ; Gray, Zool. Misc. 34; Iist. of Brit. Rad. 115, 147 ; Johnst. Brit. Zooph. ed. 2. 291 (not Syn.).

Catenicella (part.), Blainv. 1830 (agrees with character), not M.-Edwards.

" Terebripora, D'Orbigny."

Tubulipora, sp. Jameson.

1. Hippothoa catenularia. Pl. XVIII. figs. 1, 2.

Cells contiguous, ovate, thick ; aperture oblique, oval ; branches irregular.

Tubipora catenularia, Jameson, Wern. Mem. i. 561.

Tubipora catenulata, Síew. Elem. ii. 425.

Hippothoa catenularia, Flem. Brit. Anim. 531; Hassa!n, Ann.\& IIag. Nat. Hist. vi. 170; Couch, Zooph. Cornw. 43; Corn. 
Faun. iii. 101. pl. 18. fig. 5; Johnst. Hist. Brit. Zooph. ed. 2. p. 291. t. 50. figs. 9, 10; Gray, Brit. Rad. 116. Hippothoa Elliotæ, Gray, Zool. Misc. 34. Hab. Seas of Europe (ubique).

\section{Hippothoa divaricata. Pl. XVIII. figs. 3, 4.}

Cells remote, ovate lanceolate or fusiform; subcarinate in front; aperture small, with a notch in the lower margin. Ovicells small, superior, galeriform; branches given off at right angles, and usually in opposite pairs.

Hippothoa divaricata, Lamx. Expos. Méth. 82. t. 80. figs. 15, 16 ; Johnst. Hist. Brit. Zooph. ed. 2. 292. t. 51. figs. 3, 4; Audouin, Expl.i. 239; Savign. Egypt. pl. 12. f. 2 (with ovicells).

Catenicella divaricata, Blainv. D. S. N. 1830, lx. 427; Man. Act. Hippothoa lanceolata, Gray, Zool. Misc. 35; Hassall, Ann. \& Mag. Nat. Hist. vii. 366. pl. 8. figs. 5, 6; Couch, Zooph. Cornw. 43; W. Thompson, Ann. Nat. Hist. v. 252; Couch, Corn. Faun. iii. 102. pl. 18. fig. 6.

Hab. Britain. Seas of Europe.

\section{Hippothoa patagonica. Pl. XVII. fig. 1.}

Cells oval, irregularly attenuated downwards, irregularly annulate, thick; opening small, with a notch on the lower lip. Hab. Coasts of Patagonia, Falkland Islands, Darwin.

The difference between this and the preceding one is hardly greater than what occurs in many of the Polyzoa under different circumstances of age and situation; but upon comparison of the oldest cells and the most thickened I have been able to meet with in Hipp. divaricata, I am satisfied that the distinction between that species and the present is a good one.

\section{ETEA.}

Cells tubular, erect, scattered, rising from a creeping fistular fibre adnate to a foreign base. Aperture terminal or subterminal. Atea, Lamx. Bull. Soc. Phil. 1812, char.; Gray, Brit. Rad. 133.

Anguinaria, Lamk. 1812 (no char.); Johnst. Br. Zooph. ed. 2. 292. Falcaria $\beta$, Oken, Lehrb. Nat. 91, 1815.

The name Anguinaria appears on the plates devoted to the species of this genus, but subsequent consideration having shown the justice of recurring to Lamouroux's appellation, his term has been adopted in the text. 
1. Etea anguina. Pl. XV. fig. 1 .

Cells spatulate at the end; curved, ringed.

Snake Coralline, Ellis, Corall. 43. no. 11. pl. 22. fig. c, C, D.

Sertularia Anguina, Linn. Syst. ed. 10.816; Linn. Syst. 1317;

Turt. Gmel. iv. 686; Berk. Syn. i. 220; Turt.Brit. Faun. 217;

Stew. Elem. ii. 449 ; Esper, Pfanz. Sert. t. 16. figs. 1, 2; Oliv. Zool. Adriat. 291.

Cellularia Anguina, Pall.Elench. 78; Ellis, Phil. Trans. lvii. 437. pl. 19. fig. 10; Hogg's Stock. 35.

Cellaria Anguina, Ellis and Soland.Zooph. 26 ; Bosc, Vers, iii. 135. Etea Anguina, Lamx. Bull. Soc. Phil. 1812, iii. 184; Corall. 65.

pl. 3. fig. 6; Exp. Méth.9.t.65. fig. 15; Gray, Brit. Rad. 133. Falcaria Anguina, Oken, Lehrb. Nat. 91.

Sertularia mollis, D. Chiaje, Anim. s. Vert. Nap. iv. 147.

Anguinaria Anguina, Flem. Brit. Anim. 542; Lister, Phil. Trans. 1834, 385. pl. 12. fig. 4 ; Blainv. Act. 467. pl. 79. fig. 3. Anguinaria spatulata, Lamk. Anim.s. Vert. ii. 143, ed.2. ii. 196; Stark. Elem. ii. 439; Thompson, Ann. Nat. Hist. v. 252; Couch, Zooph. Cornw. 44; Corn. Faun. iii. 103. pl. 19. fig. 2; Johnst. Hist. Brit. Zooph. ed. 2. 290. t. 50. figs. 7, 8; Busk, Trans. Microsc. Soc. 1848, 15.

Hab. Britain, Seas of Europe, Atlantic Ocean, Antarctic Ocean, Tasmania, \&c.

2. Etea dilatata. Pl. XV. figs. 2, 3.

Cells cyathiform at the apex; curved, ringed. Aperture largely dilated, suborbicular.

Anguinaria dilatata, Busk, Ann. Nat. Hist. 2nd ser. vii. 85. pl. 9. fig. 14.

Hab. Torres' Strait. Port Philip.

3. Etea ligulata. Pl. XliI.

Cells very long, truncate at the extremity, straight; mouth terminal; surface not ringed; cell constricted immediately below the aperture.

Hab. Coast of Patagonia; Straits of Magellan; Darwin.

\section{Atea truncata.}

"Cells short, straight, narrowed at their origin, extremity truncate, mouth terminal, surface punctate, not ringed."

Ntea truncata, Landsborough.

$H a b$. Coast of Arran; on Laminaria.

It is nearly allied to $A$. ligulata, but quite distinct. 


\section{Beania.}

Polyzoary confervoid, subcorneous or calcareous. Cells arising one from another by a slender filiform tube given off from the lower part of the cell, which is open in front, the edges of the opening furmished with hollow spinous processes arching over the opening. Mouth terminal, with a denticle on each side.

Beania, Johnst. Brit. Zooph. ed. 2. p. 371 ; Gray, Brit. Rad. 96.

Though ranged among the Vesiculariadæ by Dr. Johnston, this "remarkable" genus, as he justly terms it, is clearly to be referred to the Cheilostomatous suborder. It is nearly allied on the one hand to Etea, and on the other, through Diachoris, to the Flustradæ. As in Diachoris, the aperture occupies nearly the entire front of the erect cell. It differs however from that genus in the uniserial arrangement of the cells, and the marginal spines which defend the sides and front of the aperture.

1. Beania mirabilis. Pl. XXIV. figs. 4, 5 .

Costæ seven to ten on each side.

Beania mirabilis, Johnst. Ann. Nat. Hist. จ. 272; Hist. Brit. Zooph. ed. 2. p. 372. f. 69, 70. Hab. Britain, on shells.

2. Beania australis. Pl. XVI. figs. 1, 2, 3 .

Costæ eighteen to twenty on each side.

Hab. Coast of Patagonia; Cape Horn, Darwin, on shells and fucus.

This species sometimes appears to form a connected frond, but the cells are not so regularly interconnected as in Diachoris, and are most usually truly uniserial.

\$2. Bi-multiserialaria. Cells disposed in a double or multiple series.

Fam. 5. Farciminariade.

Cells disposed round an imaginary axis, alternate, forming cylindrical branches of an erect, dichotomously divided, continuous polyzoary.

Farciminariadæ, Busk, MSS.

\section{Farciminaria.}

Corneous, flexible ; margin of cell much raised ; aperture occupying the whole front of the cell. Ovicell cucullate.

Farciminaria, Busk, MSS. 
See observations under the genus Salicornaria, p. 16. A second and very curious species of this genus, from South Africa, has occurred since this Catalogue was drawn up, which will be afterwards described.

1. Farciminaria aculeata, n. s. Pl. LXIV. figs. 4, 5; Pl. LXV. (bis) fig. 6.

Sides of cells within the margin beset with furcate spines. Ovicell cucullate, external; surface aculeate.

Hab. Tasmania, Hooker; New Zealand, Lyall.

Fam. 6. Gemellariade.

Cells opposite in pairs.

Gemellariadæ, Busk, Voy. of Rattlesn. i. 383.

Synopsis of Genera.

1. Gemellaria.

2. Didymia.

3. Dimetopia.

4. Notamia.

a. Each pair arising from the pair next below it. Each pair at a bifurcation giving origin to two pairs; no avicularia.

In some respects approaching the Bicellariadæ, this family would yet appear to constitute a very natural group, distinguished from the Bicellariadx, not only by general habit and the peculiar position of the cells in pairs, but also by the absence in all cases of pedunculate and articulated avicularia. Where, in this family, these organs are present, as in Noiamia, they are of a very peculiar character and in a very peculiar relation to the rest of the polyzoary. It might moreover be remarked, that the association of the genus Notamia with the others included in the same family, is somewhat forced and artificial.- 'I'he very curious structure of the polyzoary in this genus would almost justify its being regarded as the type of a distinct family, in which case the total absence of avicularia would afford an additional diagnostic character of the Gemellariadæ.

With reference to Emma crystallina, in which the cells are for the most part in pairs and apparently opposite, it must be observed, that at each bifurcation a third and alternate cell is inter"posed between the two, and that in Emma tricellata there are three alternate cells in each internode. When it is noticed also that in Menipea, for the most part, the normal number of cells in each internode is three or six, but that the latter number is not 
unfrequently reduced to five by the complete or partial abortion of one of the cells, it does not appear improbable that in Emma crystallina the apparent gemination of the cells is in fact due to the abortion of a third alternate cell in all the internodes except the one at which the bifurcation takes place.

\section{Gemellaria.}

Cells joined back to back; all the pairs facing the same way. Aperture oval, slightly oblique; at a bifurcation each cell of the primary pair giving off one of the secondary pair.

Gemellaria, Savigny, 1805 ?; Van Beneden; Johnst. Brit. Zooph. 293; Gray, List Brit. Rad. B. M. 133.

Gemicellaria, Blainv. 1830.

Loricaria, Lamx. Expos. 7 (1821), not Lacép.

Notamia, Flem. Brit. Anim. 1828.

Loricula, Cuvier, 1836.

Crisia, sp. Lamx. 1816; Lamk. 1816.

Scruparia $\beta$, Oken, Lehrb. Nat. 90, 1815.

1. Gemellaria loricata. Pl. XLV. figs. 5,6 .

The only species.

Muscus coralloides mollis elatior ramosissimus, Doody, Raii Syn. i. 34 . no. 6 .

Coat-of-mail Coralline, Ellis, Corall. 40. no. 7. pl. 21. f. b, B.

Sertularia loricata, Linn. Syst. ed. 10. 815.

Cellularia loriculata, Pall. Elench. 64; Hogg's Stock. 35.

Sertularia loriculata, Linn. Syst. 1314; Turt. Gmel. iv. 684; Berk. Syn. 1.219; Esper, Pflanz. Sert. t. 24. f. 1-3; Turt. Brit. Faun. 216; Jameson, Wern. Mem. i. 564; Stew. Elem. ii. 447.

Cellaria loriculata, Ellis and Soland. Zooph. 24 ; Bosc, Vers, iii. 133; Lamk. Anim. s. Vert. ii. 136, ed. 2. ii. 179; Johnst. Trans. Newc. Soc. ii. 262.

Scruparia loricata, Oken, Lehrb. Nat. 90.

Crisia loriculata, Lamx. Corall. Flex. 140.

Loricaria europæa, Lamx. Expos. Méthod. 7.

Notamia loriculata, Flem. Brit. Anim. 541; Farre, Phil. Trans. 1837, 413. pl. 27. f. 6-9; Hassall, Ann. \& Mag. Nat. Hist. vi. 170; Couch, Zooph. Cornw. 42 ; Corn. Faun. iii. 101. pl. 18. f. 4.

Loricula loricata, Cuvier, Règ. Anim. ed. 2. iii. 303; Templeton, Mag. Nat. Hist. ix. 469.

Gemicellaria loriculata, Blainv. Dict. Sci.Nat. lx. 425; Actinol. 461. pl. 78. f. 4 . 
Gemellaria loriculata, Savig. Egypt. Polyp.; Van Beneden, Recherch. 33. pl. 5. f. 1; Johnst. Hist. Brit. Zooph. ed. 2. 293. t. 47. f. 12, 13, 477; Gray, List Brit. Rad. 134. $H a b$. European Seas.

\section{Didymia.}

Cells joined side to side. Aperture large, oval, wholly anterior. Cells all facing the same way. At a bifurcation each cell of the primary pair giving off a secondary pair at the summit.

Didymia, Busk, Voy. of Rattlesn. i. 383.

\section{Drdyma simplex. Pl. XXXIX.}

The only species.

Didymia simplex, Busk, op. cit. 383, t. 1. f. 6 . $H a b$. Bass' Strait, 45 fathoms.

A fine species, growing in loosely branched tufts to a height of several inches. In some (dried) specimens the branches are slightly incurved, but not in all. The situation of the ovicell is peculiar. It is contained within the upper part of a cell placed between, or rather in front of the pair from which the two branches at a bifurcation take their origin. The ovicelligerous cell differs widely in form from the others, being pyriform and much attenuated below; and the orifice is below the middle. The upper compartment, in which the ovicell itself is lodged, appears to be separated from the lower by a transverse diaphragm.

\section{Dimetopia.}

Cells joined back to back. Aperture oblique ; each pair looking in a direction at right angles with that of the next. At a bifurcation the pair being disjoined, each of the disjoined cells gives off a secondary pair.

Dimetopia, Busk, Voy. of Rattlesn. i. 384.

1. Drmetopia spicata. Pl. XXIX. fig. 1.

Cells infundibuliform. Margin thickened, with numerous equidistant, elongated, acute spines.

Dimetopia spicata, Busk, op. cit. 384. t. 1. f. 9.

Hab. Bass' Strait, 45 fathoms; New Zealand, Lyall, \&c.

White and transparent, forming thick tufts about $1 \frac{1}{2}$ to 3 inches or more in height.

2. Drmetopia cornuta. Pl. XXIX. figs. 2, 3.

Cells contracted below the middle. Aperture oblique, wide 
above ; a strong conical process on each side above; one or two long projecting spines in front, inserted below the margin.

Dimetopia cornuta, Busk, op. cit. p. 384. t. 1. f. 7, 8. $H a b$. Bass' Strait, 45 fathoms.

Branches narrower than in the former species. Colour yellowish. Tufts loose; ovicell small in proportion to the size of the cells. It is placed immediately above and behind the upper margin of the aperture.

3. Each pair arising from the pair next but one below it, by tubular prolongations. A new series of cells intercalated into each branch at the bifurcation; avicularia.

\section{Notamia.}

A pair of tobacco-pipe shaped avicularia visible above each pair of cells, each arising from the inferior tubular prolongation of one of the cells in the pair next above.

Epistomia, Flem. Brit. Anim. 541, 1828; Gray, List Brit. Rad. $82,147$.

Dynamena, sp. Lamx. 1816 ; Blainv. 1830.

Notamia, sp. Flem. 1828.

Gemicellaria, sp. Blainv. 1830.

Sertularia, sp. Gmelin.

Cellularia, sp. Pallas.

1. Notamia bursaria. Pl. XLV. figs. $1,2,3,4$.

The only species.

Shepherd's-purse Coralline, Ellis, Corall.41.n. 8.t.22. f. $a, \mathrm{~A}$; Johnst. Brit. Zooph. ed. 2. 294, pl. 5l, f. 1, 2.

Sertularia bursaria, Linn. S. N. 1314 ; Berk. Syn. i. 219.

Cellularia bursaria, Pall. Elench. 65; Ellis, Phil. Trans. Ivii. 437. t. 19. f. 12.

Cellaria bursaria, Ellis \& Soland. Zooph. 25; Lamk. Hist. Anim. s. Vert. ed. 2. ii. 189.

Dynamena bursaria, Lamx. Cor. 179 ; Blainv. D. S. N. 1x. 448. Notamia bursaria, Flem. Brit. Anim. 541; Busk, Trans. Micros. Soc. ii. 110 (1847).

Gemicellaria bursaria, Blainv. Dict. S. N.1x.425; Man. Act. 461. Sertularia bursa, Turt. Brit. Faun. 216. Epistomia bursaria, Gray, List Brit. Rad. 82.

Hab. Britain (south-east).

The true systematic position of this highly interesting species seems to have been held, even as lately as 1847, in considerable doubt; for although Dr. Johnston, in the 2nd edition of Brit. 
Zooph., places it doubtfully next to Gemellaria, he at the same time says that he was more inclined then than formerly to arrange it with Sertularia. He very shrewdly surmises the real nature of the tobacco-pipe-like processes in comparing them with the "bird's-head" processes in the Cellularix, though wrong in supposing that there is any analogy between them and the "somewhat similar organs" in Laomedea obliqua. In a paper in the Transactions of the Microscopical Society (cited above), an endeavour is made to show the true nature of this Polyzoon and to describe the somewhat complicated structure of the polyzoary.

\section{Fam. 7. Cabereade.}

Polyzoary dichotomously divided into ligulate, bi-multiserial branches; on the backs of which are vibracula, or avicularia, one common to several cells; avicularia sessile.

Cabereadæ, Busk, Voy. of Rattlesn. i. 376.

Synopsis of Genera.

1. Caberea.

2. Amastigia.

\section{Caberea.}

Cells bi-multiserial, in the latter case quincuncial. Back of branches covered with large vibracula, which are placed obliquely in two rows, diverging in an upward direction from the middle line, where the vibracula of either side decussate with those of the other. Avicularia, when present, sessile on the front of the cell. Caberea, Lamx. Corall. 128, 1816; Blainv. 1830; Gray, Cat. Brit. Rad. 147.

Selbia, Gray, Dieffenb. N. Z. ii. 292 ; Cat. Brit. Rad. 147.

Crisia (sp.), Audouin, Expl.

Cellaria (sp.), Lamk. Savigny, Egypt. pl. 12.

Cellularia (sp.), Fleming, Johnst.

a. Operculate. With a pedunculate operculum in front of the aperture.

The remarkable feature of this genus resides in the vibracula, which here appear to attain their utmost development. Each vibraculum appears to belong, not to a single cell, as in Scrupocellaria, but to be common or applied to the backs of several. They are more or less pyriform or long oval in shape, and the two rows decussate with each other along the middle of the branch, giving, in the narrower forms especially, much of the aspect of an ear of barley, and in the wider of a straw plait. The walls of the vibracula are usually thin and very transparent, so as 
to allow the outlines of the cells to be seen imperfectly through them. The upper extremity of the vibraculum is bifid, and to the inner horn or tooth is articulated the "seta," and from the notch between the two horns there is continued nearly, if not quite to the inner or lower extremity of the organ, and along its upper border, a shallow groove, in which is lodged the seta when in a state of rest. In most species the seta is serrated on one side with distant teeth.

\section{Caberea rudis. Pl. XlVi.}

Multiserial. Aperture oval, margin much thickened, with a strong projecting upturned spine on each side, in the central cells, and with three strong and long spines on the outer side, and a smaller one on the inner side in the marginal cells. Operculum spatulate, wide, entire. Each cell of the central rows with two small avicularia in front inmediately below the aperture. Each marginal cell with a single large avicularium in front below the aperture. Vibracula slender, very transparent. Setæ short, not serrated.

Caberea rudis, Busk, Voy. of Rattlesn. i. 377. Hab. Bass' Strait.

Colour dirty white. Forms a broad frondose polyzoary 2 inches or more in height. The branches all disposed in the same plane, are flat, thick, and about $\frac{1}{8}$ th inch wide, composed of 4-6 rows of comparatively small cells, which viewed behind appear lozenge or diamond-shaped, and arranged quincuncially. It is not always easy to observe with accuracy the outline of the vibracula, owing to the extreme tenuity of their walls, but the groove along the upper border is very distinct, and most usually has the seta lying in it. The avicularia on the marginal cells are very large, but not uniform in size. Along each border of the branches runs a bundle of radical tubes, the number of which diminishes as the branch ascends, owing to the circumstance that each tube terminates in the base of a vibraculum.

2. Caberea boryi. (Cab. zelanica, Pl. XVI. figs. 4, 5. Cab. patagonica, Pl. XXXVIII.)

Cells biserial; aperture oval, pedunculate operculum expanded principally downwards, and sometimes sending off a process to the opposite side of the aperture; a single spine on the inner side springing from the peduncle of the operculum; two marginal spines on the outer side of the aperture. Ovicell large, arcuate. Vibracula ovoid. Setæ serrated.

Crisia Boryi, Aud. Expl.; Savign. Egypt. pl. 12. f. 4. Selbia zelanica, Gray, Dieffenb. N. Z. ii. 292. 
Caberea zelanica, Busk, Voy. of Rattlesn. i. 378.

Hab. Cumberland Island. New Zealand, Hooker; E. Falkland

Islands; S. Patagonia, $49^{\circ} \mathrm{S}$.; Port St. Julian, Patagonia ; Strait of Magellan, Darwin; Coast of Devon, Miss Cutler. Algoa Bay.

This appears to be one of the most generally diffused species, and it varies also considerably in some respects, according to its age and other circumstances, perhaps of depth or temperature, \&c. To observe the specific characters here assigned, it is necessary to examine the younger or more perfect cells at the extremity of the branches, the older ones by continued deposition of calcareous matter being considerably altered, and also usually deprived of the spines. But the most remarkable difference is in the conformation of the pedunculate operculum. As shown in Pl. XVI. fig. 4, this process extends quite across the aperture of the cell, forming a sort of bridge, from the lower margin of which depends the expanded lamina, and this appears to be the condition in which it was figured by Savigny; whilst in $\mathrm{Pl}$. XXXVIII. figs. 2, 6, 7, it will be seen that the operculum is not connected with the opposite side of the aperture, but of the more usual form. Upon sufficient examination however it will be found that both forms run insensibly into each other. The recent discovery of this species on the coast of Devonshire is of great interest. It there grows in minute tufts upon Eschara foliacea, and has probably hitherto been overlooked, owing to its resemblance to Canda reptans.

\section{ß. Inoperculatæ. No pedunculate operculum.}

3. Caberea hookeri. Pl. XXXVII. fig. 2.

Bi-triserial. Marginal cells with two marginal spines above and one on the inner side. Central cells with a marginal spine on each side of the aperture above. Setæ serrated.

Cellularia Hookeri, Flem. Brit. Anim. 539 (1828); Johnst. Hist. Brit. Zooph. ed. 2. 338. t. 60. f. 1, 2.

Bicellaria Hookeri, Blainv. Dict. Sc. Nat. Ix. 424.

Hab. Torquay, Hooker; Orkneys, E. F. Barlee.

\section{?4. Caberea lata. Pl. Xlvil.}

Bi-multiserial ; marginal cells with a single subapical spine; central cells without marginal spines; setæ serrated.

Caberea lata, Busk, op. cit. i. 378.

Hab. Australia; New Zealand (an præced. varietas ?). 
Colour white or yellowish; forms close rounded tufts 2 to 3 inches high and wide, composed of uniform dichotomously divided branches about $\frac{1}{8}$ th of an inch wide, and which become wider towards their truncate extremities. The vibracula are very large, and though distinctly defined, are yet sufficiently transparent to allow a view of the lozenge-shaped cells. The central rows of cells vary in number from two to five, and the cells composing them are arranged with extreme regularity. The marginal rows are placed in a plane posterior to the central, and the cells of which they are composed are widely different from the central.

It is not easy to distinguish the narrower forms of this species from Caberea hookeri, and they may not improbably really belong to one and the same species, differing only in consequence of the difference in the localities in which they are found. The warmer latitudes of New Zealand and Australia may readily be supposed to produce a more luxuriant growth, and consequently wider and stronger branches of the polyzoary. But there are other differences, which though less obvious, would better serve to indicate a specific distinction between the two forms. In $\mathrm{Cab}$. hookeri there is a large tubular spine on each side of the mouth in the lateral cells, and each of the central cells, or nearly so, are furnished with an anterior avicularium, below the aperture and to one side. The lateral avicularium also of the marginal cells is much larger.

\section{Amastigia ( $\alpha$ priv., $\mu a ́ \sigma \tau \iota \xi)$.}

An avicularium to about each three cells on the back of the branches (no vibracula).

In this genus the vibracula on the back of the branches are replaced by avicularia; but it is to be remarked that in these avicularia, contrary to what usually obtains in those organs, the moveable mandible, when closed, points downwards; in this respect resembling the seta of the vibraculum, with which it is in fact strictly homologous.

\section{Amastigia nuda. Pl. XXXVI.}

Cells bi-quadriserial; posterior avicularia small, the mandible pointing downwards. A lateral and anterior avicularium to each lateral cell : an anterior one to each of those in the central rows. Aperture oval, with a broad pedunculate operculum and two spines on each side above.

Caberea nuda, Busk, MSS. t. 36 . Hab. Tierra del Fuego, Darwin. 
Fam. 8. Bicellariade.

Polyzoary dichotomously divided into narrow ligulate, bi- or multiserial branches. No vibracula. Avicularia when present pedunculate and articulated. Polyzoary erect; phytoid.

Bicellariadæ, Busk, Voy. of Rattlesn. i. 373.

Bugulidæ, Gray, Cat. Brit. Rad. 110, 146.

\section{Synopsis of Genera. \\ 1. Bicellaria. \\ 2. Halophila. \\ 3. Bugula.}

\section{Bicellaria.}

Cells turbinate, distant. Aperture directed more or less upwards. Several spines, marginal or dorsal.

Bicellaria, Blainv. D. S. N. 1830; Gray, Cat. Brit. Rad. 112.

Cellularia, Flem. Brit. Anim. 1828.

Cellularia, sp. Pallas.

Cellaria, sp. Soland.; Lamk. 1816.

Bugula a, sp. Oken, Lehrb. Nat. 89.

\section{Bicellaria ciliata. Pl. XXXIV.}

Aperture oval looking obliquely upwards and forwards. Five to seven very long, slender, incurved marginal spines on the outer edge of the aperture. One to two dorsal spines. A single, long, slender, submarginal spine at the lower part of the aperture. Ovicell subpedunculate, attached to the inner edge of the aperture. Avicularia capitate, affixed to the lower and outer part of the cell.

Ciliated Coralline, Ellis, Corall. 38. no. 5. pl. 20. d, D. Sertularia eiliata, Linn. Syst. 1316; Berk. Syn. i. 230 ; Esper, Pflanz. Sert. t. 14. f. 1, 2.

Cellularia ciliata, Pall. Elench. 74; Flem.Brit. Anim. 540.

Cellaria ciliata, Ellis and Soland. Zooph. 24; Lamk. Anim. s. Vert. ii. 139, ed. 2. ii. 186.

Bugula ciliata, Oken, Lehrb. Nat. 89.

Crisia ciliata, Lamour. Corall. 60; Templeton, Mag. Nat. Hist, ix. 468; Van Beneden, Mém. 51.pl. 6. f. 9-11.

Bicellaria ciliata, Blainv. Act. 459; Gray, Cat. Brit. Rad. 112. Cellularia ciliata, Johnst. Brit. Zooph.291.pl.38. f. 1,2; Couch. Zooph. Cornw. 56; Corn. Faun. ii. 126. pl. 23. f. 1; Johnst. Hist. Brit. Zooph. ed. 2. 335. t. 58. f. 1, 2. Hab. European Seas. 


\section{Bicellaria gracilis. Pl. XXXII.}

Cells much elongated, slender, aperture round or suboval, looking obliquely forwards and upwards ; three marginal, and 2-3 submarginal spines above and behind the aperture, and two much longer ; curved, hair-like spines on the anterior and lower margin. Ovicells globose, subpedunculate, attached to the upper and inner part of the margin of the aperture. Avicularia small, capitate, on the sides of the cells; rare.

Bicellaria gracilis, Busk, Voy. of Rattlesn. i. 374 .

Hab. Bass' Strait, 45 fathoms.

A delicate slender species, not unlike $B$. ciliata in habit, but sufficiently distinguished from it by the number and arrangement of the spimes, and especially by the curious double spine on the front of the cell.

\section{Bicellaria grandis. Pl. Xliv.}

Cells tubular below, much expanded above. Aperture oval, the narrow end outwards, looking upwards and forwards ; $2-5$ long curved submarginal spines; a single dorsal spine on the outer side, about half way down the cell. Avicularia - ? ? (probably deficient).

Bicellaria grandis, Busk, l. c. 374 .

Hab. Bass' Strait, 46 fathoms.

Quite distinct from B. ciliata, not only in its size, which is nearly three times as great, but also in the form of the cells and of the aperture. The number of spines varies very much, and two or three of them not unfrequently arise from a broad common projecting process or base.

\section{Bicellaria tuba. Pl. XXXi.}

Aperture round. looking nearly directly upwards; a digitiform hollow process below the outer border supporting $2-4$ long incurved spines ; $2-3$ other, long curved submarginal spines behind or above the aperture, none below it in front. A solitary spine on the back a short way down the cell. Avicularia very long, trumpet-shaped, arising from the back of the cell.

Bicellaria tuba, Busk, Voy. of Rattlesn. i. 373.

$H a b$. Bass' Strait, 45 fathoms.

At once recognizable by the remarkable form and unusual position of the avicularium, and also by the peculiar digitiform spinigerous process on the outer side of the aperture. 


\section{Halophila.}

Cells contiguous, attenuated downwards, much expanded upwards with a large plain aperture; unarmed.

Halophila, Gray, Dieff. New Zealand, ii. 292, 1843; Cat. Brit. Rad. 147.

Bicellaria (sp.), Busk, Voy. of Rattlesn. i. 375.

\section{Halophila johnstonize. Pl. XXX.}

Cells obliquely truncated above with a short spine on the outer angle; aperture large, oval. Margin slightly thickened.

Halophila Johnstoniæ, Gray, l. c. Bicellaria flexilis, Busk, Voy. of Rattlesn. i. 375. Hab. Bass' Strait; New Zealand.

Of a light grey or lead colour, growing in large loose tufts 3 or 4 inches in height, and composed of long forked ascending branches. There appears to be very little calcareous matter in the substance of the polyzoary, which is consequently soft and flexible. Within some of the cells, in the lower or contracted portion, is a curious little tridentate organ, the nature of which is not obvious.

\section{Bugula.}

Cells elliptical (viewed behind), closely contiguous, bi-multiserial; aperture very large; margin simple, not thickened. Avicularia, when present, pedunculate and articulated (frequently coloured red or bluc).

Bugula a, sp. Oken, Lehrb. Nat. 89, 1815 (type); Gray, Cat. Brit. Rad. 114.

Bugula $\beta$, Oken, l. c. 90 .

Acamarchis, Lamx. 1816; Blainv. 1830.

Crisia, sp. Lamx. 1812.

Cellularia, sp. Pallas; Johnst. Brit. Zooph. i. 340 (sp.).

Cellaria, sp. Soland.; Lamk. 1816.

Bugula, Gray, List Brit. Rad. 114.

Avicularia (sp.), T. V. Thompson, MSS.

Bugulina (sp.), Gray, Cat. Brit. Rad. 114. Crisularia (sp.), Gray, Cat. Brit. Rad. 114, 117.

As the typical species of the genus, as here constituted, is $B$. neritina, which was also taken by Oken as the type of his genus Bugula, recurrence to his name appears to be unavoidable, notwithstanding the more general use that has since been made of Lamouroux's appellation, "Acamarchis." The necessary correc. tion must be made in the Plates of this Catalogue. 
1. Bugula neritina. Pl. XliII.

Cells quadrangular, lengthened, with a truncated summit, the angles projecting.

Remarkable Coralline, Ellis, Phil. Trans. abridg. x. 345. pl. 8. figs. a, A, G; Ellis, Corall. 35. pl. 19.

Sertularia neritina, Linn. Syst. 1315; D. Chiaje, Anim. s. Vert. Nap. iv. 147 ; Esper, Sert. t. 13. fig. 1-3.

Cellularia neritina, Pall. Elench. 67; Flem. Brit. Anim. 539;

Johnst. Hist. Brit. Zooph. ed. 2. 340. t. 60. figs. 3, 4.

Cellaria neritina, Ellis and Soland. Zooph. 22; Lamk. Anim.s.

Vert. ed. 2. ii. 190 (ex var. B.), Esper, t. 13. figs. 1, 2, 3.

Bugula neritina, Oken, Lehrb. Nat. 89.

Acamarchis neritina, Lamx. Cor. Flex. 58. pl. 3. fig. 2 ; Zooph.6 ;

Risso, L'Europ. Mérid. v. 318; Blainv. Dict. Sc. Nat. lx. 423; Man. Act. 459. pl. 77. fig. 3; Busk, Ann. Nat. Hist. 2nd ser. vii. pl. 8. figs. $5,6,7$.

Crisia neritina, Lamx. Bull. Soc. Phil. 1812, iii. 183.

Bugula neritina, Gray, List of Brit. Rad. 114.

$H a b$. Britain (Scarborough, Bean). New Zealand! Hooker, Dar-

win, Lyall. Auckland Islands! Hooker. Australia (ubique)!

Rio de Janeiro! Lyall. America (North?), Ellis. Red Sea.

Bay of Honduras.

Although very generally distributed throughout the globe, and perhaps more so than most of the Polyzoa, it appears extremely doubtful whether this species really belongs to the British Fauna. The only British specimen I have seen or been able to hear of, is that in Dr. Johnston's collection now in the British Museum, and found by Mr. Bean at Scarborough. The other forms included under the same name by Dr. Johnston, as well as those collected by Lieut. Thomas at Copinstra and off Tynemouth, all belong to Cellularia peachii: so that, unless the specimen mentioned by Dr. Fleming, as collected by Miss Blackburne on the coast of Cheshire, should really belong to A. neritina, it might be concluded that Mr. Bean's specimen was one accidentally introduced by some vessel from abroad.

\section{Bugula flabellata. Pl. LI., LII.}

Cells multiserial, oblong, truncate above with one or two spines at each upper angle. Aperture extending to the bottom. Avicularia on the sides of the cell capitate; surface smooth. Ovicells cucullate with a very wide opening.

Corallina cum appendiculis lateralibus avium capitum formâ, Ellis, Corall. pl. 38. fig. 7.

Cellularia Avicularia $\beta$, Pallas, Elench. 68.

Flustra avicularis, Sow. Brit. Misc. ii. 21. pl. 71 ; Flem. Brit, Anim. 506; Johnst. Trans. Newc. Soc. ii. 265; Blainv, Dict. 
Sci. Nat. lx. 416; Man. Act. 451 ; Couch. Zooph. Cornw. 54; Corn. Faun. iii. 122; Johnst. Hist. Brit. Zooph. ed. 2. 346. t. 63 . figs. 3,4 .

? Flustra angustiloba, Lamk. Hist. Anim. s. Vert. ed. 2. ii. 222. Flustra capitata, Hogg's Stock. 36.

Crisia flustroides, Lamour. Corall. Flex. 141?

Avicularia flabellata, J. V. Thompson, MSS. Brit. Mus.; Gray, List of Brit. Rad. 106.

Hab. Britain. Seas of Europe.

\section{Bugula avicularia. Pl. LIII.}

Cells biserial, elongate, contracted below. Aperture not reaching quite to the bottom, obovate; above with two spines on the outer side and one on the inner. Avicularia on the side of the cell, capitate, surface granular or areolated. Ovicells superior, subglobular, opening small.

Bird's-head Coralline, Ellis, Corall. 36. no. 2. pl. 20. fig. a, A. Cellularia avicularia, Pall. Elench. 68; Johnst. Brit. Zooph. 292. pl. 36. figs. 7, 8; Couch, Zooph. Cornw. 58; Corn. Faun. iii. 128; Van Beneden, Recherch. 41 \& 48. pl. 6. figs. 1-8; Johnst. Hist. Brit. Zooph. ed. 2. 338. t. 63. figs. 7, 8. Sertularia avicularia, Linn. Syst. 1315; Berk. Syn. i. 220. Cellaria avicularia, Ellis and Soland. Zooph. 22 ; Lamk. Anim. s. Vert. ed. 2. ii. 191 ; Johnst. Trans. Newc. Soc. ii. 26. Bugula avicularia, Oken, Lehrb. Nat. 90.

Crisia avicularia, Lamx. Bull. Soc. Phil. 1812, iii. 183; Cor. Flex. 141 ; Templeton, Mag. Nat. Hist ix. 468.

Cellularia avicularis, Reid, Ann. \& Mag. Nat. Hist. xvi. 389. $H a b$. Seas of Europe.

\section{Bugula plumosa. Pl. Liv.}

Cells elongated, much attenuated below. Aperture as wide as the cell above, elliptical below, with a short conical spine at the upper and outer angle. Avicularia capitate, affixed close to the outer margin of the aperture. Ovicell superior, globular.

Corallina pumila erecta ramosior, Raii Syn. i. 37. no. 20. t. 2. fig. 1 ; Ellis, Phil. Trans. abridg. x. 346. pl. 8. fig. b, B, D. Soft-feathered Coralline, Ellis, Corall. 33. no. 1. pl. 18. fig. a, A. Sertularia fastigiata, Linn. Syst. 1314 ; Fabr. Faun. Gronl. 445; Berk. Syn. i. 219.

Cellularia plumosa, Pall. Elench. 66; Couch, Corn. Faun. iii. 128. pl. 23. fig. 4; Johnst. Hist.Brit.Zooph.ed. 2. 341.t. 61. figs. 1-5. Cellularia fastigiata, Blumenb. Man. 273; Flem. Brit. Anim. 539. Cellaria plumosa, Ellis and Soland. Zooph. 21 ; Lamk. Anim. s. Vert. ed. 2. ii. 190. 
Crisia plumosa, Lamour. Bull. Soc. Phil. 1812, iii. 185 ; Corall. 62.

Crisia fastigiata, Templeton, Ann. \& Mag. Nat. Hist. ix. 468. Bicellaria plumosa, Blainv. Dict. Sc. Nat. Ix. 424; Act. 459. Crisularia plumosa, Gray, Brit. Rad. p. 111.

Hab. Britain.

5. Bugula dentata. Pl. XXXV.

Cells biserial, oblong, rounded at each end. Aperture oval; three marginal spines on the outer side and one on the inner. Avicularia lateral, capitate. Ovicell superior, cucullate (colour blue).

Acamarchis tridentata, Krauss, Zooph. d. Südsee, p. 31. fig. 2. Acamarchis dentata, Lamx. Exp. Méth. p. 6. tab. 5. fig. 1-3; Hist. Pol. Flex. p. 135. pl. 3. fig. 3. Cellaria neritina, var. B., Lamk. ii. 19].

Hab. Australia. New Zealand, Hooker, Lyall. Tasmania, Hooker. South Africa.

Notwithstanding the difference in the number of spines on the outer edge of the aperture assigned to this species by Lamouroux and by Krauss, there can be little doubt but that they intend one and the same species. The statement made by Lamouroux, that his $A$. dentata is " $d$ 'une couleur plombée," is strongly confirmatory of this supposition.

\section{Bugula murrayana. Pl. LiX.}

Cells multiserial, elongated, contracted about the middle and downwards. Aperture oval, with two, three or four, incurved marginal spines on the outer edge and one on the inner. A strong, hollow, spinous process on each side of the top of the cell, and a capitate articulated avicularium on the front of some of the cells below the aperture.

Flustra Murrayana, Bean, MSS.; Johnst. Hist. Brit. Zooph. ed. 2. 347. t. 63 . figs. 5,6 .

? Sertularia spiralis, Olivi, Zool. Adriat. 291. t. 6. f. 2.

Flabellaria spiralis, Gray, List of Brit. Rad. 106.

Hab. Britain (north and east).

Fam. 9. Flustrade.

Polyzoary flexible, expanded, foliaceous, erect, sometimes decumbent and loosely attached. Cells multiserial, quincuncial or irregular.

Flustra, Linn.; Johnst. Brit. Zooph. ed. 2. 342.

Flustradx, Gray, Cat. Brit. Rad. B. M. 145, 1818 (part.). 
Escharidx (part.), Johnst. Brit. Zooph. ed. 1. 248, ed. 2. 263 ; Gray, Syn. Brit. Mus. 1842, 135.

Polypiers à réseau, Lamk. 2 ed. ii. 210 (part.).

Flustrées, Lamx. Exp. Méth. 2 (part.).

The principal distinctive character between the Flustradx, as here intended, and the very closely allied group of the Membraniporidæ, consists in the more or less erect and free condition of the former. Since however, on the one hand, a Flustra, as is often the case in Flustra foliacea, may be decurrent at the base and spread to a considerable extent in the adnate form ; and on the other, a Membranipora, as in the case of the socalled Flustra membranacea (Membranipora flustroides, mihi), is occasionally, as when spreading over Flustra foliacea for instance, nearly free, it would seem that this distinction is hardly sufficient to allow of their being regarded as belonging to two distinct families : the relationship, in other words, between the Flustradæ, as here constituted, and the genus Membranipora, is more that of family and subfamily. The latter genus might therefore almost be considered as the type of a subfamily, the Membraniporana. The distinction again between the Flustradx and the Escharadæ on the one hand, and between Membranipora and Lepralia on the other, seems, in the former case at least, to be, if not wholly, at least in great part, artificial. The distinction drawn between the flexibility of the Flustradx and the rigidity of the Escharadæ may perhaps be looked upon as artificial, but beyond this, the Escharadæ exhibit characters, principally in connexion with the avicularia, which would indicate a more natural distinction between the two groups. The distinction between Membranipora and Lepralia is in some respects greater and more natural, as will be indicated in speaking of those genera.

Synopsis of Genera.

1. Flustra.

2. Carbasea.

3. Diachoris.

1. Flustra.

Cells contiguous; on both sides of the frond.

Flustra, sp. Linn.

Flustra, Lamk. Syst. 1801; Gray, Cat. Brit. Rad. 145.

1. Flustra foliacea. Pl. LV. figs. 4, 5. Pl. LVI. fig. 5.

Cells arched and expanded above with two marginal spines on each side, contracted and truncate below. Avicularium and mandible semicircular. 
Fucus marinus scruposus albidus telam sericeam textura sua æmulans, Morris, Aist. Plant. iii. 646. t. 8. f. 16 (bona).

Fucus telam lineam sericeamve textura sua æmulans, Raii Syn. 42. no. 9 ; Jussieu, Mém. Acad. Roy. des Sc. 1742, 298. pl. 10. f. 3.

Broad-leaved Hornwrack, Ellis, Corall. 70. no. 2. pl.29. f. a, A, $\mathrm{B}, b$.

Curious Sea-weed, Hooke, Microg. 140. pl.9. f. 2, pl. 14. f. 1.

Eschara foliacea, Linn. Syst. ed. 10, 804; Pall. Elench. 52.

Flustra foliacea, Linn. Syst. 1300; Müll Zool. Dan. Prod.253; Ellis and Soland. Zooph. 12. pl. 2. f. 8; Esper, Pflanz. Flust. t. 1. fs. 1, 2; Van Beneden, Recherch. 56. pl. 7. fs. 11, 17 ; Berk. Syn. i. 214; Lamk. Anim. s. Vert. ed.2. ii. 219; Grant, Edin. New Phil. Journ. iii. 111, 337 ; Flem. Brit. Anim. 535; Johnst. Trans. Newc. Soc. ii. 263; Mag. Nat. Hist. iii. 483. f. 120; Templeton, ibid. ix. 469; Risso, L'Europ. Mérid. v. 333 ; Blainv. Actinol. 450. pl. 75. f. 1; Couch, Zooph. Cornw. 53; Corn. Faun. iii. 121. pl. 21. f. 1; Johnst. Hist. Brit. Zooph. ed. 2. 342. t. 62. fs. 1, 2; Gray, List Brit. Rad. 103. $H a b$. Seas of Europe (universal). Society Islands, E. Forbes.

2. Flustra papyracea. Pl. LV. figs. 6, 7 .

Cells oblong, slightly enlarged upwards; a short marginal spine at each upper angle. Avicularia - ?

Eschara papyracea utrinque cellifera, summitatibus securis aciei instar truncatis, Ellis, Corall. pl. 38. f. 8.

Flustra papyracea, Ellis and Soland. Zooph. 13; Flem. Brit. Anim.535; Lister, Phil. Trans. 1834, 384. pl. 12.f. 3 ; MilneEdwards, Lam. Anim. s. Vert. ed. 2. ii. 220 (note 2); Blainv. Dict. Sci. Nat. 1x.451; Lister, Phil. Trans. 1834, pl.12. f. 3.

F. chartacea, Turt. Gmel. iv. 663; Turt. Brit. Faun. 209; Stew. Elem. ii. 436; Couch, Corn. Faun. iii. 121 ; Johnst. Hist. Brit. Zooph. ed.2.343. t.60. f. 5, 6; Lamx. Pol. Flex. 104 ; Risso, Hist. Nat. de l'Europ. Mér. v. 533.

Chartella papyracea, Gray, List. Brit. Rad. 104.

Hab. Britain (south?).

3. Flustra truncata. Pl. LVIII. figs. 1,2 ; \& Pl. LVI. figs. $1,2$.

Cells linear, oblong, with an unarmed border. Avicularium elliptical, mandible semicircular.

Fucus marinus scruposus, Raii Syn. 42. no. 10; Morris, Hist. Plant. Oxon. iii. 546. t. 1. fig. 17 (opt.).

Narrow-leaved Hornwrack, Ellis, Corall.69. no. 1. t. 28. fig. 1. a, A, B. 
Porus cervinus minor, Marsigli, Hist. Phys. de la Mer, pl. 63. pl. 6. figs. 23, 24 .

Eschara foliacea $\beta$, Linn. Syst. ed. 10. 804.

E. securifrons, Pall. Elench. 56.

Flustra truncata, Linn. Syst. 1300; Müll.Zool. Dan.Prod.253; Ellis and Soland. Zooph. 11; Berk. Syn. i. 214; Esper, Pflanz. Flust. t. 3. figs. 1, 2; Oliv. Zool. Adriat. 274; Lamk. Anim. s. Vert. ed. 2. ii. 219; Grant, loc. cit. 111 ; Flem. Brit. Ani.n. 535; Johnst. Trans. Newc. Soc. ii. 264. pl. 12. fig. 1 ; Templeton, Mag. Nat. Hist. ix. 469; Johnst. Hist. Brit. Zooph. ed. 2. 344. t. 62. figs. 3, 4; Blainv. Dict. Sci. Nat. lx. 415 .

Chartella securifrons, Gray, List of Brit. Rad. 104. Hab. Britain (north and east chiefly). Australia!

4. Flustra octodon. Pl. LVIII. fig. 5; \& Pl. LVI. fig. 4.

Cells slender, pyriform, elongated, with three or four strong, hollow, pointed, incumbent, marginal denticles on each side, in the upper half of the cell. Avicularium oblong, mandible semicircular.

Hab. Coast of Spain, $M^{\star}$ Andrew.

5. Flustra denticulata. Pl. LVI. fig. 7. \& Pl. LVil.

Cells much elongated, nearly linear; a thick, hollow, upturned spine on each upper angle. Margin beset throughout the entire length of the cell with numerous thick, hollow, simple and blunt or bifurcate dentate processes, which arise from the front edge of the margin; sides of the cell immediately within the edge denticulate, with numerous minute, pointed denticles. Avicularia conical; mandible placed with its base oblique, point produced, acute.

Hab. Australia, B. M.

Var. a. (inermis). Pl. XLIX. figs. 3, 4 .

Without the larger anterior teeth, or with but very few.

F. denticulata, Busk, op. c. i. 380.

Hab. Bass' Strait.

The very curious dentate processes on the edges of the cells render this species very conspicuous, but the total absence, or nearly so, of these external appendages in some instances renders the aspect of various specimens so different, that it requires some attention to perceive their identity. The peculiar form and position of the avicularium, and the presence of the internal or submarginal denticles, are the characteristic diagnostic marks. 


\section{Carbasea.}

Cells contiguous; on one side only of the frond.

Flustra, sp. Linn.; Johnst. Brit. Zooph. 345.

Carbasea, Gruy, Cat. Brit. Rad. 103, 117, 1848.

a. Aperture occupying the entire front of the cell or very nearly so.

1. Carbasea papyrea. Pl. L. fig. 1, 2, 3.

Cells oblong, narrowed and truncate below, convex, unarmed. Avicularia —? Ovicell - ?

Porus cervinus, Marsigl. Hist. Phys. de la Mer, 64. pl. 6. figs. $25,26$.

Eschara papyrea, Pall. Zooph. 56.

Flustra Carbasea, Ellis and Soland. Zooph. 14. pl. 3. figs. 6, 7 ; Turt. Gmel. iv. 663; Jameson, Wern. Mem. i. 563 ; Turt. Brit. Faun. 209; Stew. Elem. ii. 436; Lamk. Anim. s. Vert. ed. 2. ii. 221; Flem. Brit. Anim. 535; Grant, Edin. New Phil. Journ. iii. 111; Johnst. Trans. Newc. Soc. ii. 264. pl. 9. fig. 4; Templeton, ut sup. cit. 469; Roget, Bridgw. Treat. i. 165. figs. 63, 64; \& 172. figs. 69, 70; Dalyell, Edin. New Phil. Journ. xvii. 413 ; Rep. Brit. Assoc. 1834, 603; Blainv. Dict. Sci. Nat. Ix. 415 ; Johnst. Hist. Brit. Zooph. ed. 2. p. 345. t. 63. figs. 1, 2.

Flustra papyracea, Esper, Pflanz. Flust. t. 2. figs. 1-3. Carbasea papyracea, Gray, List of Brit. Rad. 103. $H a b$. Britain (north and east).

2. Carbasea pisciformis. Pl. LV. figs. 1,2 ; \& Pl. LVI. fig.6. Cells, viewed behind, elongated, truncated at both ends, contracted at the waist; in front, pyriform, much expanded in the middle, contracted at top and tapering downwards, slightly expanding again at the end. Ovicells immersed, marked with radiating lines.

$H a b$. Tasmania, B. $M$.

3. Carbasea armata. PI. XlIX. figs. 1, 2.

Cells, viewed behind, oblong, narrowed and truncate below ; in front oval, with a projecting angle on each side about the middle. Marginal cells each with a large sessile avicularium on the outer side. Ovicell -?

$\mathrm{Hab}$. South Africa.

The peculiar character of this species, and by which it is readily distinguished from all others, consists in the presence upon each 
of the marginal cells of a large sessile, well-formed avicularium. The frond attains a height of several inches, having linear truncate segments, slightly dilated towards the end, of a red-brown colour, generally with one or two dark spots. It appears to be very abundant in Algoa Bay.

In Krauss' 'Zooph. d. Süds.' p. 35, a new species of Flustra, or rather of Carbasea, is described under the name of Flustra marginata, of which figures are also given, minutely and highly finished. In general habit, and in the front view of the cells, there is not the slightest resemblance between this form and $\mathrm{Car}$ basea armata; but what is given as the back view of the cell, in Krauss' figure very curiously, bears a striking resemblance to the front view in C. armata; and although, in the description of his species, Krauss takes no notice of the lateral avicularia, they are very clearly represented in this figure. It might therefore be supposed that Krauss has confounded two distinct species under his $F$. marginata.

4. Carbasea cribriformis. Pl. LXVIII. fig. 1.

Cells oval, irregularly disposed. Frond reticulated. Ovicells cucullate, immersed.

Retepora cornea, Busk, Voy. of Rattlesn. i. 380. Hab. Off Cumberland Island, 27 fathoms.

The peculiar reticulated frond of this species is so different from that of any other of its congeners, as at once to distinguish it. This form shows very strikingly how artificial some of the generic distinctions in this class of Polyzoa are; for, except in the flexible, horny consistence of the frond, there is no distinction between $C$. reticulata and a Retepore.

\section{B. Aperture occupying only part of the front of the cell.}

5. Carbasea dissimilis. Pl. L. figs. 4, 5, 6, 7 .

Cells pyriform, much attenuated below. Aperture oval, anterior. Marginal cells with an acute, short, spinous process above on the outer side. A sessile projecting avicularium in front of each cell below the aperture.

F. carbasea, var. $\beta$., Lamk. Ann. s. V. ii. 221 . ii. $2 \mathrm{~d}$ ed. Hab. Tasmania, Hooker.

This species indicates the transition between the Flustradx and Cellulariadæ. In the form especially of the outer cells, and in the presence of anterior avicularia upon most of them, it resembles Menipea. The continuous polyzoary however, and the fiondose habit, are sufficient to indicate its true position. 
6. Carbasea episcopalis. Pl. XLVIII. figs. 1,2 ; \& Pl. LV. fig. 3.

Cells pyriform, cylindrical or barrel-shaped, back marked with transverse rugæ. Aperture circular superior. Ovicells lofty, keeled. Avicularia 0 .

F. pyriformis? Lamx. Pol. Flex. 103. pl. 1. fig. 4; Blainville, Man.d'Act. 451; Lamk. An. s. Vert. ii. 221; Busk, Voy. of Rattlesn. i. 379.

Hab. Bass' Strait, 45 fathoms.

Sometimes small and parasitic, upon Sertularians and Polyzoa; sometimes independent, then of large growth, forming dichotomously divided fronds, with strap-shaped, truncate, unequal segments. From its general resemblance to Lamouroux's figure, it is not improbable that this may be his F.pyriformis; but as it is impossible to determine this with certainty, either from his figure or description, (which are equally applicable to several other species,) it has been thought better to give it a new designation. The one employed is suggested by the form of the ovicells, which bear a close resemblance to a bishop's mitre.

7. Carbasea bombycina. Pl. XLVIII. figs. 4, 5, 6, 7.

Cells pyriform, cylindrical, smooth. Aperture small, circular, superior; a lunate pore in the front of the cell a short distance below the aperture; one to four perforations, in a series on either side of the cell, above and in front. Ovicell marked with radiating lines. Avicularia 0.

? F. bombycina, Ellis and Soland. Zooph. 14.pl.4. fig. B; Linn. Syst. Nat. ed. 13. 3828, no. 9; Bosc. Vers, 117 ; Lamx. Hist. Pol. Flex. 103. no. 196; Exp. Méth. 3. t. 4. fig. B; Lamk. Ann. s. V. ii. 220. 2nd ed.; Krauss, Z. d. Südsee, 35. Hab. Algoa Bay, Mossel Bay, South Africa.

The figure of $F$. bombycina, given by Ellis and Solander, bears a sufficiently near general resemblance to the species here designated $C$. bombycina, to render it probable that they may be identical, though this is by no means certain. Considering the locality whence the present species is derived, it may not perhaps be unlikely that it represents that intended by Ellis, when he says (speaking of his $F$. bombycina, which came from the Bahama Islands), "I have some elegant specimens from the East Indies that approach very near to this kind."

8. Carbasea ovoidea. Pl. XliX. figs. 5, 6, 7 .

Cells elongated, slightly contracted below. Aperture oval, two- 
thirds the length of the cell, velum very convex. Ovicell $\longrightarrow$ ? Avicularium 0.

Hab. S. Patagonia, Darwin.

Margin of frond divided by shallow notehes into small rounded lobes. The specific name is derived from the regularly oval form of the aperture, which is filled in by a very convex transparent velum.

9. Carbasea elegans. Pl. LIV. figs. 6, 7 ; \& Pl. LVI. fig. 3.

Cells oblong. Aperture nearly as long as the cell, truncate or square below. Surface behind smooth. Ovicell _-? Avicularium 0 .

Hab. Tasmania.

The cells in this species most nearly resemble those of Flustra papyracea: they are however less linear and more rounded at the top, and not so long in proportion to their width. The little filling-in of the aperture at bottom affords a distinctive character, as does the absence of avicularia, were the generic difference between the two overlooked.

\section{Carbasea indivisa. P1. LVIII. figs. 3, 4.}

Frond semicircular, undivided, subplicated; cells oblong, surface behind granulated. Ovicells —? Avicularia 0.

Hab. New Zealand, Hooker.

\section{Diachoris.}

Cells disjunct, each connected with six others by tubular processes; frond sometimes partially adnate and decumbent.

Diachoris, Busk, Voy. of Rattlesn. 382.

The mode of arrangement and interconnexion of the cells in this genus is remarkable and highly interesting. It represents, in fact, a dissected Flustra. The cells are disposed in linear parallel series, and those of two contiguous series are alternate with respect to each other. Each cell is connected with one at either end in the same linear series by a rather wide, short tubular prolongation, and with two on each side in the contiguous series by narrower tubes; so that each cell, except in the marginal rows, is connected with six others. The species, though stated to be loosely adnate, are also capable of rising into independent erect fronds, like the other Flustradæ, and in the other form would be more correctly described as decumbent than adnate, as they are very loosely connected to the foreign base upon which they lie. 


\section{Diachoris crotali. Pl. LXVI. figs. 1, 2.}

Cells erect, open in front, with straight sides; perforated on the sides and bottom; a lanceolate appendage articulated to each upper angle. Ovicell small, conical, superior.

Diachoris crotali, Busk, Voy. of Rattlesn. 382. tab. i. figs. 10, 12. Hab. Bass' Strait.

The frond, although, as explained above, not strictly adnate, as it seems to have no attachments, is usually spread loosely over other Polyzoa. There is no appearance of a moveable mandible in the lanceolate appendages, which nevertheless most probably represent avicularia. These organs are of a lanceolate form, with an elevated ridge or keel along the back, and slightly concave beneath : they project in front, slightly depending, and at the base of each is a rounded eminence.

\section{Diachoris magellanica. Pl. LXVII.}

Cells semi-erect, open in front, oval; mouth circular with a thickened and raised margin. A pedunculate and articulated, capitate avicularium attached to the margin of the cell near the top on each side. Ovicell — ? and also loosely adnate.)

Hab. Straits of Magellan, Darwin; New Zealand, Lyall.

\section{Diachoris inermis. Pl. LXXII.}

Cells decumbent, boat-shaped, entirely open; two short marginal spines on each side near the top. Ovicell - ? Avicularium —?

Hab. New Zealand, Lyall. Straits of Magellan, Darwin.

This species approaches very nearly to a Membranipora, and from the total absence of any moveable appendages, might perhaps be regarded as a type of a distinct genus : as, however, it is a solitary instance of the form, and agrees in the structure of the polyzoary with the above two species, it has been associated with them and not with the Membraniporidæ. 


\section{DESCRIPTION OF PLATES.}

Plate

I. Fig. 1, Catenicella lorica, p. 6, natural size; fig. 2, front ; fig. 3. back.

II. Fig. 1. Catenicella rentricosa, p.7, front ; fig. 2, back. Fig. 3. Catenicella hastata, p. 7, front; fig. 4, back.

III. Fig. 1. Catenicella ventricosa, p. 7, (var.) front; fig. 2, back; fig. 3, ovicell.

Fig. 4. Catenicella ventricosa, p. 7, (var. maculata) front; fig. 5 , back.

IV. Fig. 1. Catenicella aurita, p. 8, front; fig. 2, back; fig. 3, ovicell.

Fig. 4. Catenicella amphora, p. 8, front; fig. 5, back.

V. Fig. 1. Catenicella plagiostoma, p. 8, front; fig. 2, back.

Fig. 3. Catenicella cribraria, front; fig. 4, back.

VI. Fig. 1. Catenicella margaritacea, p. 9, front; fig. 2, side view ; fig. 3 , back.

Fig. 4. Catenicella carinata, p. 12, front; fig. 5, ovicell; fig. 6 , side view.

VII. Fig. 1. Catenicella formosa, p. 9, front; fig. 2, back. Fig. 3. Catenicella gibbosa, p. 12, front; fig. 4, back.

VIII. Fig. 1. Catenicella perforata, p. 10, front; fig. 2, back and side views.

Fig. 3. Catenicella ringens, p. 10, front; fig. 4, back. 
Plate

IX. Fig. 1. Catenicella elegans, p. 10 (var. South Africa), front; fig. 2, back; fig. 3 (var. Australia), front; fig. 4, back.

X. Fig. 1. Catenicella cornuta, p. 11, front ; fig. 2, back ; fig. 3 , side view.

Fig. 4. Catenicella umbonata, p. 11, front; fig. 5, back.

XI. Fig. 1. Catenicella taurina, p. 12, front ; fig. 2, back; fig. 3 , with ovicells; fig, 4, spines replaced by avicularia.

XII. Fig. 1. Calpidium ornatum, p. 15, natural size; fig. 2, front.

XIII. Fig. 1. Calpidium ornatum, p. 15, front view of bifurcation; fig. 2, back of cell.

XIV. Fig. 1. Alysidium lafontii, p. 14, front of cell; fig. 2, side view, showing the avicularium; fig. 3 , back; fig. 4. back, at a bifurcation; fig. 5 , natural size.

Fig. 6. Alysidium parasiticum, p. 14, front, with an ovicell; fig. 7, back; fig. 8, side view; fig. 9 , natural size.

XV. Fig. 1. Ftea anguina, p. 31.

Fig. 2. Etea dilatata, p. 31.

XVI. Fig. 1. Beania anstralis, p. 32 ; fig. 2 , portion of cell to show the lateral processes; fig. 3 , a more highly magnified view of the costa.

Fig. 4. Caberea boryi, p. 38, front; fig. 5, back.

XVII. Fig. 1. Hippothoa patagonica, p. 30 .

Fig. 2. Scruparia chelata, p. 29.

XVIII. Fig. 1, 2. Hippothoa catenularia, p. 29.

Fig. 3, 4. Hippothoa divaricata, p. 30.

XIX. Fig. 1. Menipea fuegensis, p. 2], front view; fig. 2, back view; fig. 3 , larger view of mouth of cell with the avicularium.

XX. Fig. 1. Menipea cirrata, p. 21, front; fig. 2, back. Fig. 3, 5. Menipea ternata, p. 21, front; fig. 4, back. 
Plate

XXI. Fig. 1. Scrupocellaria scrupea, p. 24, front ; fig. 2, back.

Fig. 3. Canda reptans, p. 26, front; fig. 4, back.

XXII. Fig. 1. Scrupocellaria ferox, p. 25, front; fig. 2, back; fig. 5 , ovicell.

Fig. 3. Scrupocellaria scruposa, p. 25, back; fig. 4, front.

XXIII. Fig. 1. Menipea patagonica, p. 22, mode of origin.

Fig. 2. Menipea triseriata, p.22, front; fig. 3, back; fig. 4, ovicells.

XXIV. Fig. 1. Scrupocellaria macandrei, p. 24, front ; fig. 2, back; fig. 3 , radical tube.

Fig. 4. Beania mirabilis, p. 32, side view of cell; fig. 5 , enlarged view of costce.

XXV. Fig. 1. Menipea patagonica, p. 22, front; fig. 2, 3, back.

XXVI. Fig. 1, 2. Menipea patagonica, p. 22, variety. Fig. 3. Cellularia ornata, p. 20, front; fig. 4, back.

XXVII. Fig. 1. Cellularia cuspidata, p. 19, front; fig. 2, back. Fig. 3. Cellularia peachii, p. 20, front ; fig. 4 , back; fig. 5, ovicell.

XXVIII. Fig. 1. Scrupocellaria diadema, p. 24, front; fig. 2, back; fig. 3, ovicell.

Fig. 4. Scrupocellaria cyclostoma, p. 24, front; fig. 5 , back.

XXIX. Fig. 1. Dimetopia spicata, p. 35.

Fig. 2. Dimetopia cornuta, p. 35; fig. 3, ovicell.

XXX. Fig. 1. Halophila johnstonix, p. 43, natural size; fig. 2, back; fig. 3, front.

XXXI. Fig. 1. Bicellaria tuba, p. 42, front; fig. 2, back, with avicularium; fig. 3 , occasional mode of connexion of cells; fig. 4, ovicell.

XXXII. Fig. 1. Bicellaria gracilis, p. 42, natural size; figs. 2, 4, front; figs. 3,5 , back.

XXXIII. Fig. 1. Canda arachnoides, p. 26, natural size; figs. 2, 4, front ; fig. 3, back ; fig. 5, avicularia at the lower part of a branch. 
Plate

XXXIV. Fig. 1. Bicellaria ciliata, p. 41, natural size; fig. 2, front; fig. 3 , back; fig. 4 , ovicells ; fig. 5 , avicularia.

XXXV. Fig. 1. Bugula dentata, p. 46, natural size; fig. 2, front; fig. 3 , back; fig. 4 , side; fig. 5 , avicularia.

XXXVI. Fig. 1. Amastigia nuda, p. 40, natural size; figs. 2,3, front; fig. 4, back; fig. 5, dorsal avicu. larium.

XXXVII. Fig. 1. Caberea hookeri, p. 39, natural size; fig. 2, front; fig. 3 , back.

XXXVIII. Fig. 1. Caberea boryi, p. 38, natural size; fig. 2, front ; fig. 3 , back; figs. 4, 5, side; figs. 6,7, younger cells.

XXXIX. Fig. 1. Didymia simplex, p. 35, natural size; fig. 2, front; fig. 3, front with ovicell.

XL. Fig. 1. Emma crystallina, p. 28, natural size; fig. 2, front; fig. 3 , back.

XLI. Fig. 1. Emma tricellata, p. 28, front; fig. 2, back.

XLII. Atea ligulata, p. 31.

XLIII. Fig. 1. Bugula neritina, p. 43, natural size; fig. 2, front; figs. 3, 4, back; figs. 5, 6, ovicells.

XLIV. Fig. 1. Bicellaria grandis, p. 42, natural size; fig. 2, front; fig. 3 , back.

XLV. Fig. 1. Notamia bursaria, p. 36, natural size; fig. 2, front; fig. 3 , back; fig. 4, Diagram to represent the mode of connexion of the cells.

Fig. 5. Gemellaria loricata, p. 34, natural size; fig. 6 , back and side.

XLVI. Fig. 1. Caberea rudis, p. 38, natural size; fig. 2, front; fig. 3, back.

XLVII. Fig. 1. Caberea lata, p. 39, natural size; fig. 2, front; fig. 3 , back.

XLVIII. Fig. 1. Carbasea episcopalis, p. 52, natural size; fig. 2 , front; fig. 3 , back. 
Plate

XLVIII. Fig. 4. Carbasea bombycina, p. 52, natural size; fig. 5, front; fig. 6, back; fig. 7, ovicells.

XLIX. Fig. 1. Carbasea armata, p. 50, natural size; fig. 2, front.

Fig. 3. Flustra denticulata (var. inermis), p. 49, natural size; fig. 4, magnified.

Fig. 5. Carbasea ovoidea, p. 52, natural size; fig. 6 , front; fig. 7, back.

L. Fig. 1. Carbasea papyrea, p. 52, natural size; fig. 2, front; fig. 3 , back.

Fig. 4. Carbasea dissimilis, p. 51, natural size; fig. 5 , front; fig. 6, back; fig. 7, avicularium.

LI. Fig. 1. Bugula flabellata, p. 44, natural size; fig. 2, front; fig. 3, avicularium (more magnified).

LII. Bugula flabellata, p. 44, back.

LIII. Fig. 1. Bugula avicularia, p. 45, natural size; fig. 2, front; fig. 3 , back; fig. 4, avicularium.

LIV. Fig. 1. Bugula plumosa, p. 45, natural size; fig. 2, front; fig. 3 , back; fig. 4, ovicell; fig. 5 , avicularium.

Fig. 6. Carbasea elegans, p. 53, front; fig. 7, back.

LV. Fig. 1. Carbasea pisciformis, p. 50, front; fig. 2, back. Fig. 3. Carbasea episcopalis, p. 52, front (without ovicells).

Figs. 4, 5. Flustra foliacea, p. 47.

Figs. 6, 7. Flustra papyracea, p. 48.

LVI. Figs. 1, 2. Flustra truncata, p. 48.

Fig. 3. Carbasea elegans, p. 53.

Fig. 4. Flustra octodon, p. 49.

Fig. 5. Flustra foliacea, p. 47.

Fig. 6. Carbasea pisciformis, p. 50 .

Fig. 7. Flustra denticulata, p. 49.

LVII. Fig. 1. Flustra denticulata, p. 49, portion of frond; fig. 2, a single cell with avicularium more highly magnified.

LVIII. Figs. 1, 2. Flustra truncata, p. 48.

Fig. 3. Carbasea indivisa, p. 53, front; fig. 4, back.

Fig. 5. Flustra octodon, p. 48.

Fig. 6. Membranipora telacea. Vid. Part II. 
Plate

LIX. Fig. 1. Bugula murrayana, p. 46, front; fig. 2, back.

LX. Fig. 1. Menipea multiseriata, p. 22, front; fig. 2, back.

LXI. Fig. 1. Membranipora lineata,. Vid. Part II. Fig. 2. Membranipora membranacea. Vid. Part II.

LXII. Fig. 1. Scrupocellaria cervicornis, p. 24, front ; fig. 2, back; fig. 3, pedunculate operculum; fig. 4, marginal spines.

LXIII. Figs. 1, 2. Salicornaria malvinensis, p. 18.

Fig. 3. Salicornaria gracilis, p. 17.

Fig. 4. Salicornaria tenuirostris, p. 17.

Fig. 5. Salicornaria teuuirostris, var. $a$, p. 17.

LXIV. Fig. 1-3. Salicornaria farciminoides, p. 16.

Fig. 2. Var. (sinuosa).

Figs. 4, 5. Farciminaria aculeata, p. 33.

Fig. 6. Nellia oculata, p. 18.

LXV. Fig. 1. Nellia simplex, p. 19.

Fig. 2. Vincularia ornata.

Fig. 3. Membranipora cyclops.

Fig. 4. Membranipora grandis. Vid. Part II.

Fig. 5. Membranipora galeata.

Fig. 6. Membranipora rozieri.

LXV.(*). Fig. 1. Salicornaria malvinensis, p. 18, natural size.

Fig. 2. Salicornaria gracilis, p. 17, natural size.

Fig. 3. Nellia simplex, p. 19, natural size.

Fig. 4. Nellia oculata, p. 18, natural size.

Fig. 5. Salicornaria farciminoides, p. 16, natural size.

Fig. 6. Farciminaria aculeata, p. 33, natural size.

Fig. 7. Farciminaria flexilis, natural size. Vid. Part II.

LXVI. Fig. 1. Diachoris crotali, p. 54, front; fig. 2, back; fig. 3 , side (reduced).

LXVII. Fig. 1. Diachoris magellanica, p. 54, front; fig. 2, back; fig. 3, side.

LXVIII. Fig. 1. Carbasea cribriformis, p. 51.

Fig. 2. Membranipora telacea. Vid. Part II. 
N.B. The present Part contains about one-half of the Cheilostomatous suborder, the remainder of which will be included in a second. Owing to the rapid accumulation of materials during the progress of the Work, it has not been possible to adhere to any regular sequence in the Plates, and it has been found necessary to reserve one Plate (LXXII.), containing the figures of Diachoris inermis, for the ensuing part of the Catalogue : for the same reason also the figures of several species of Membranipora and of a species of Vincularia, to be afterwards described, appear in Plates LVIII., LXI., LXV, and LXVIII.

G. B. 


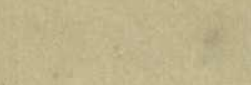

(3)

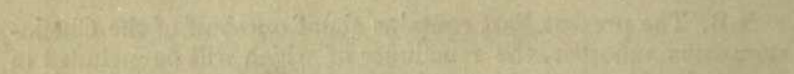

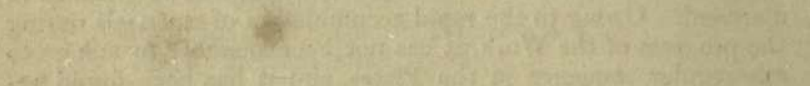
is

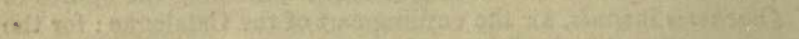

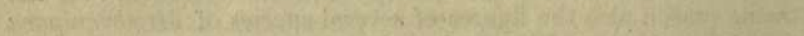

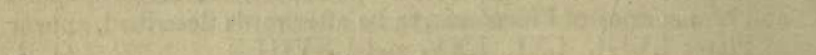

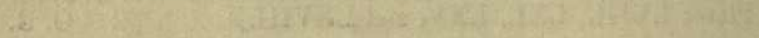



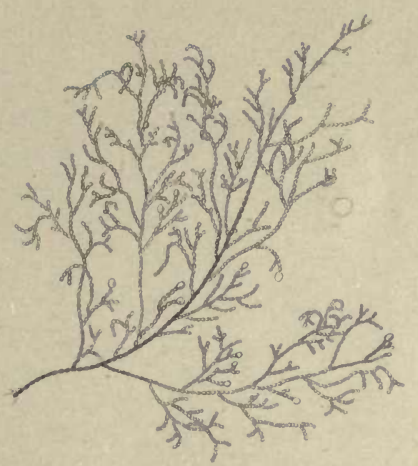

nat.size.

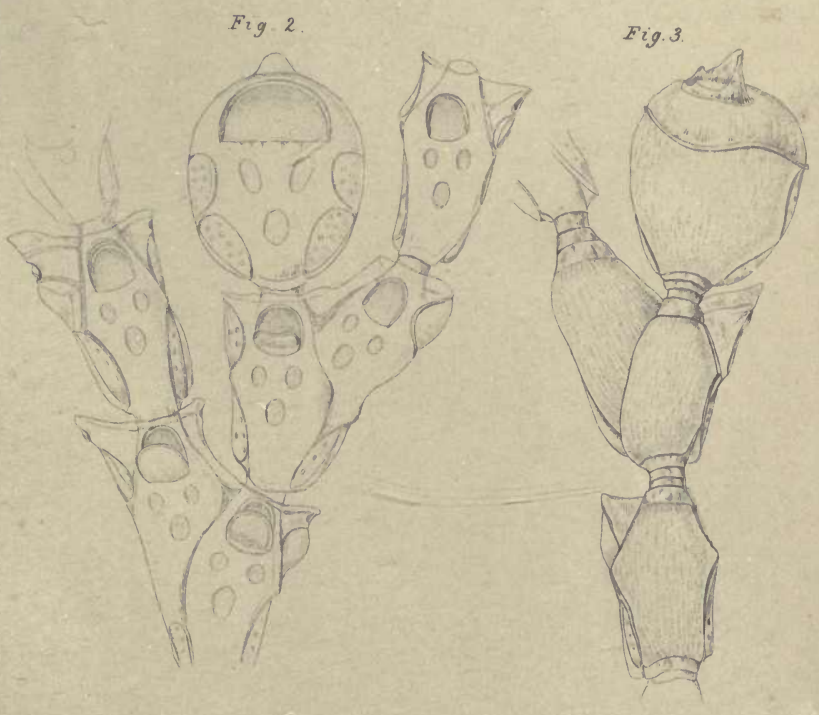

Catenicella Iorica. 



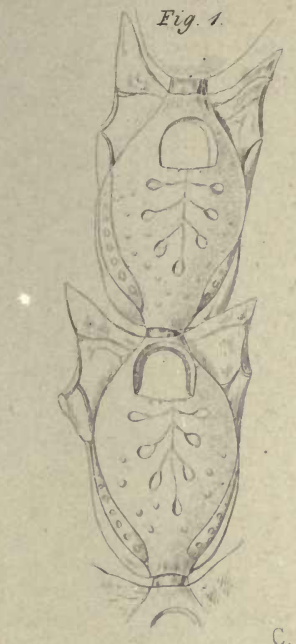

Fig. 2

PI.II

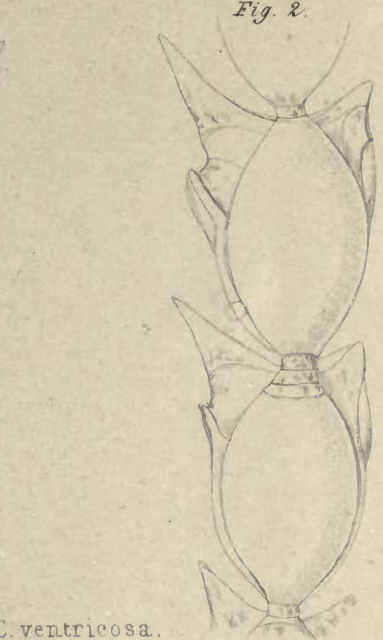

Fig 9.
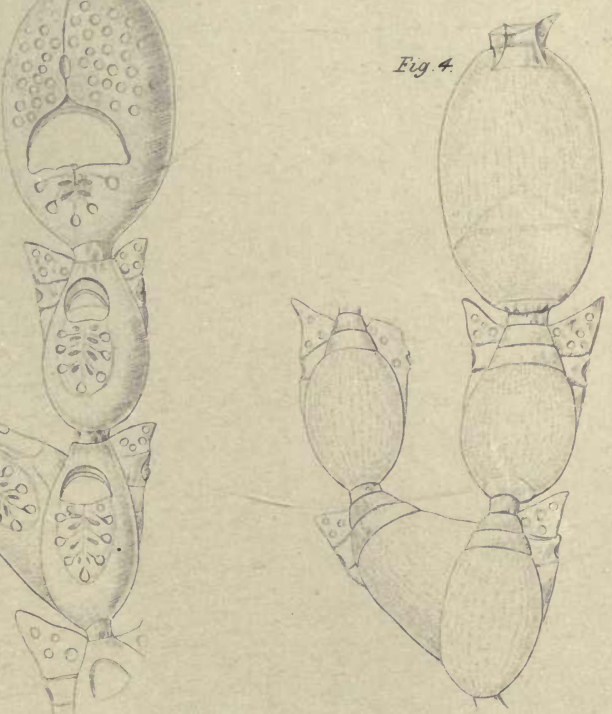

C. hastata. 

Fig 1.
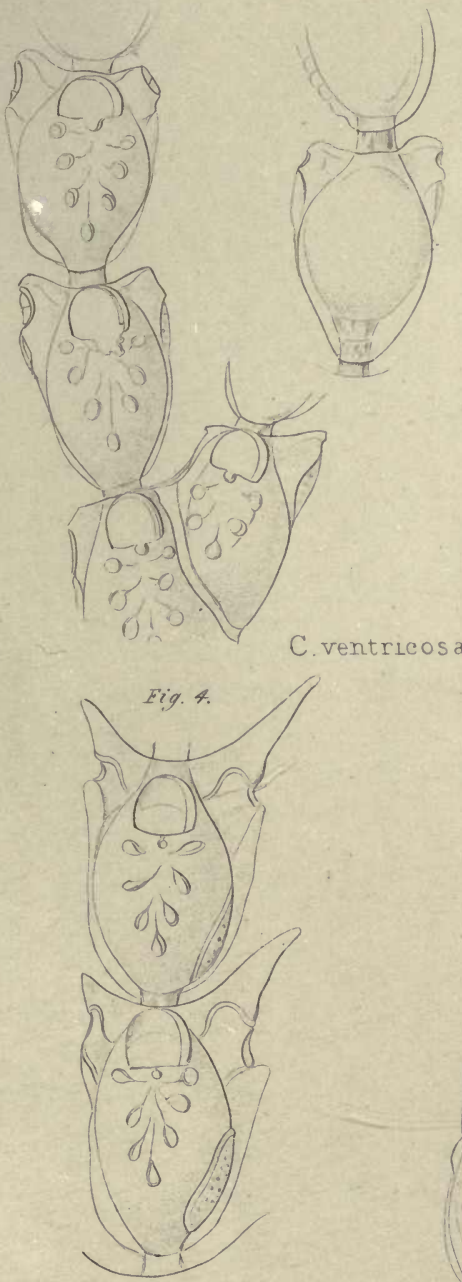

Fy. 2 .

Fig. 3

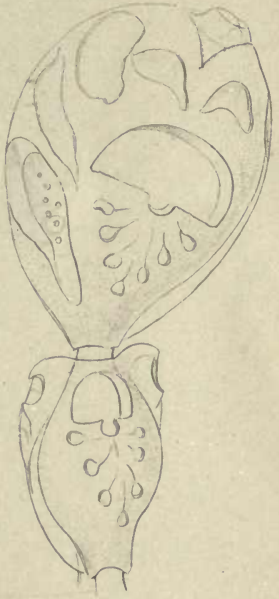




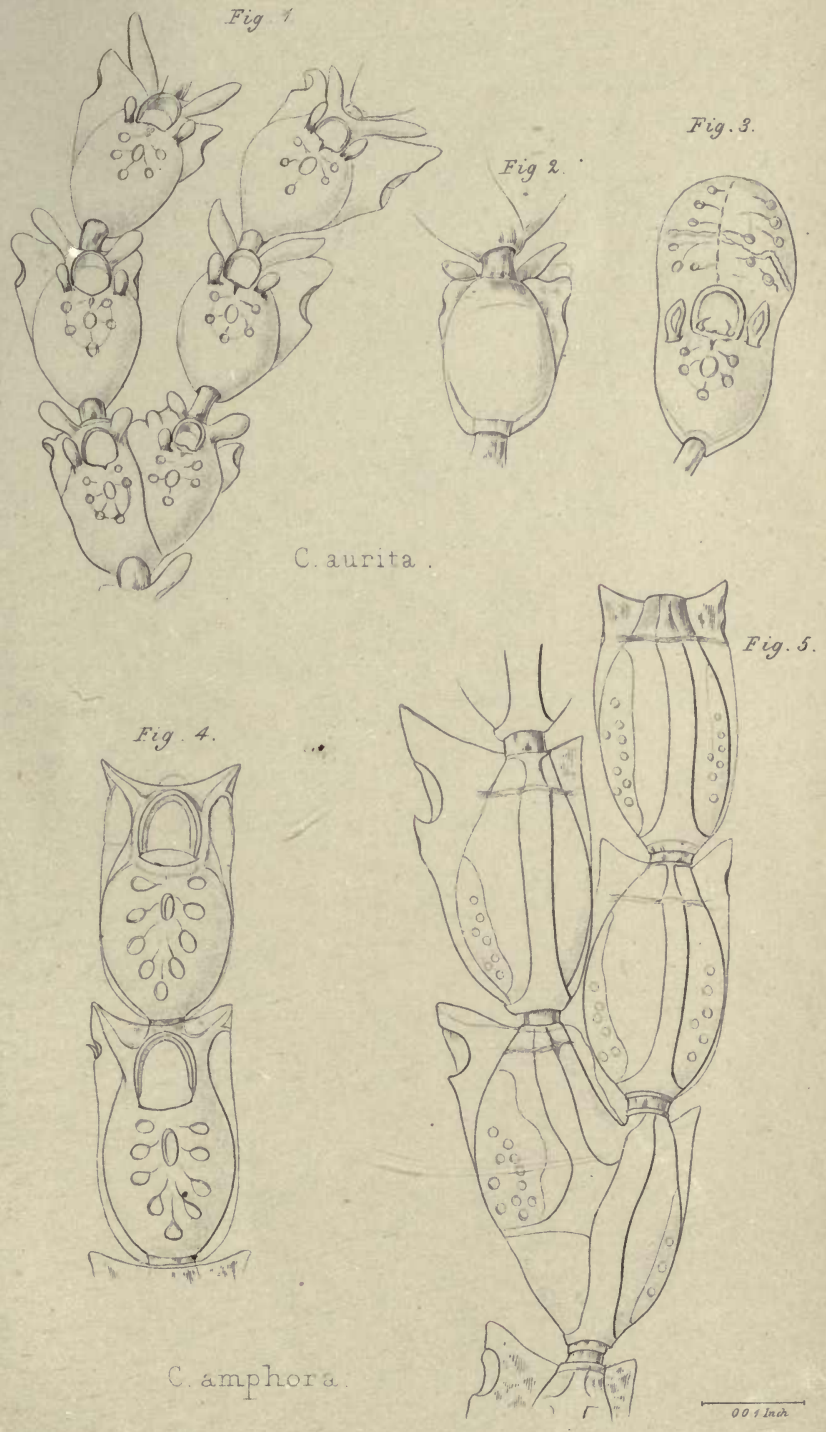



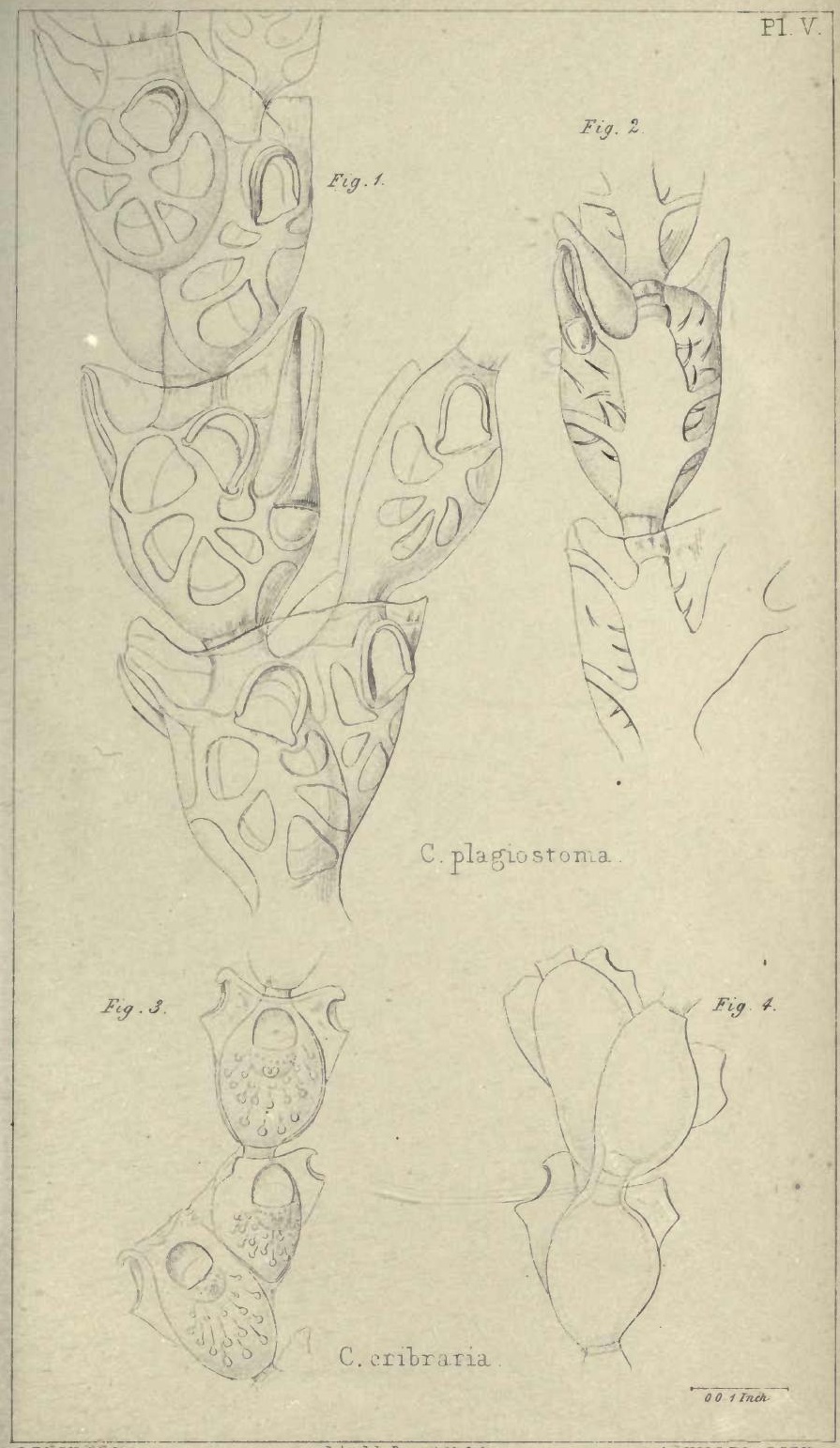





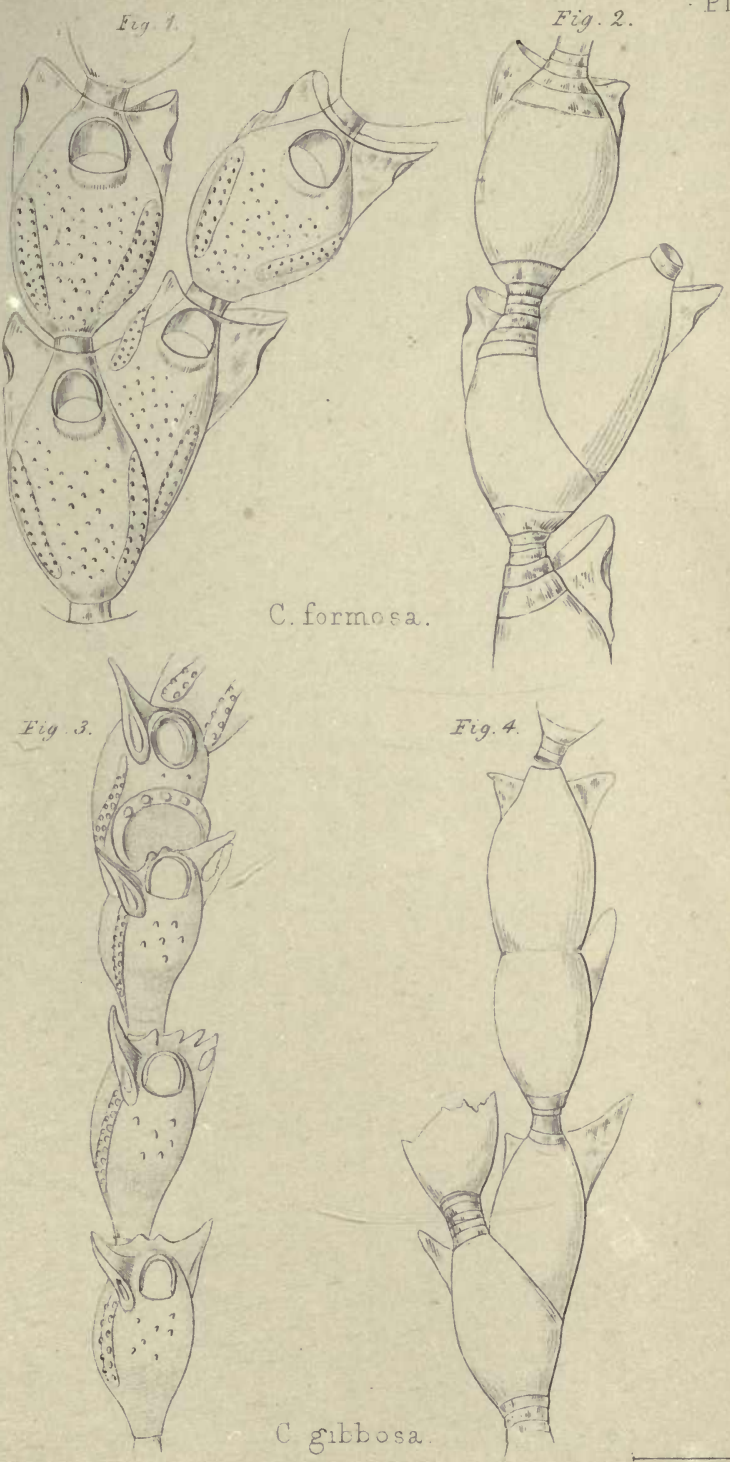

$00.1 .1 x c h$. 


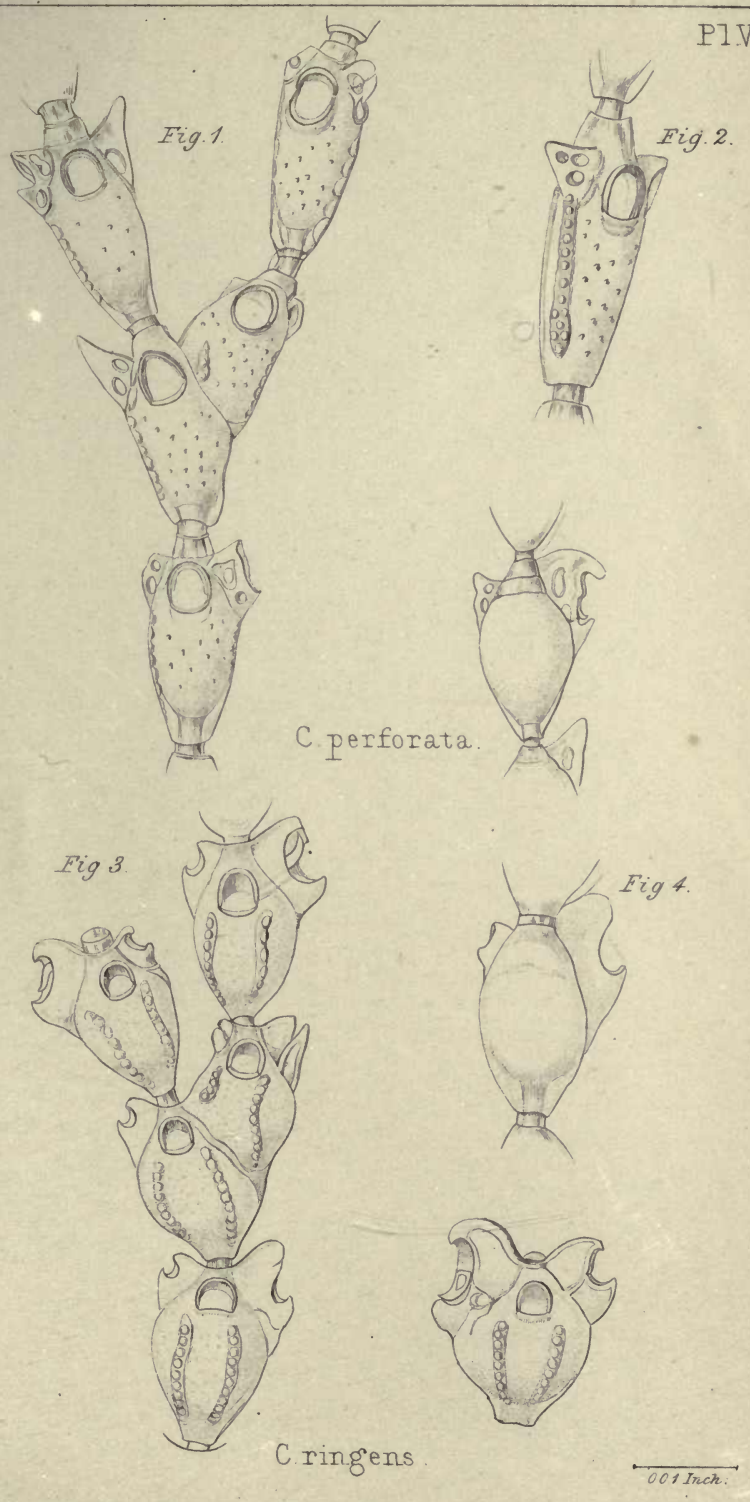



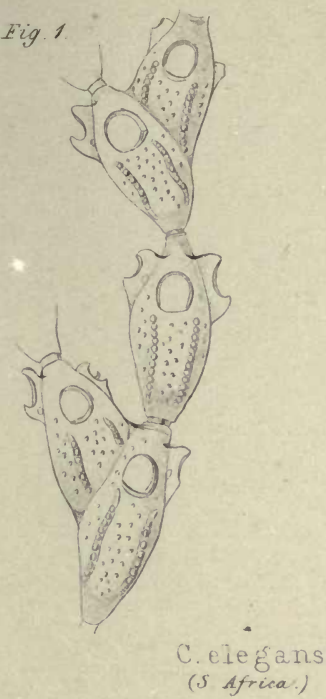

PI IX

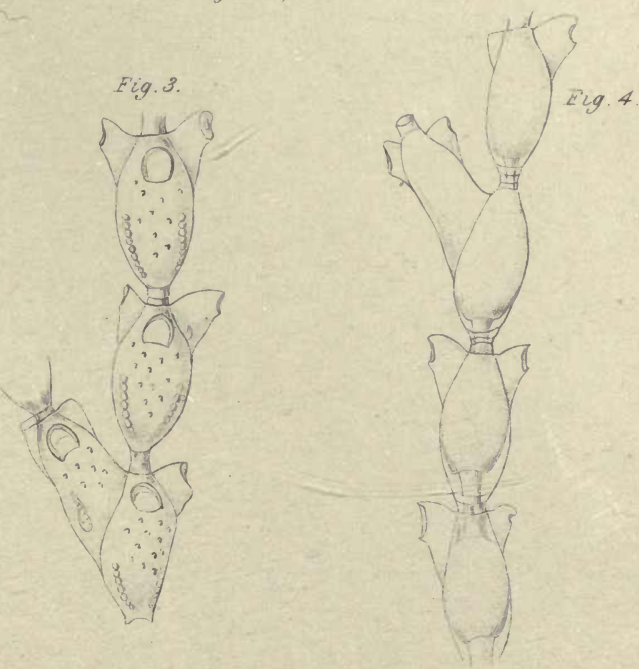

C. elegans:(Awtratza) 


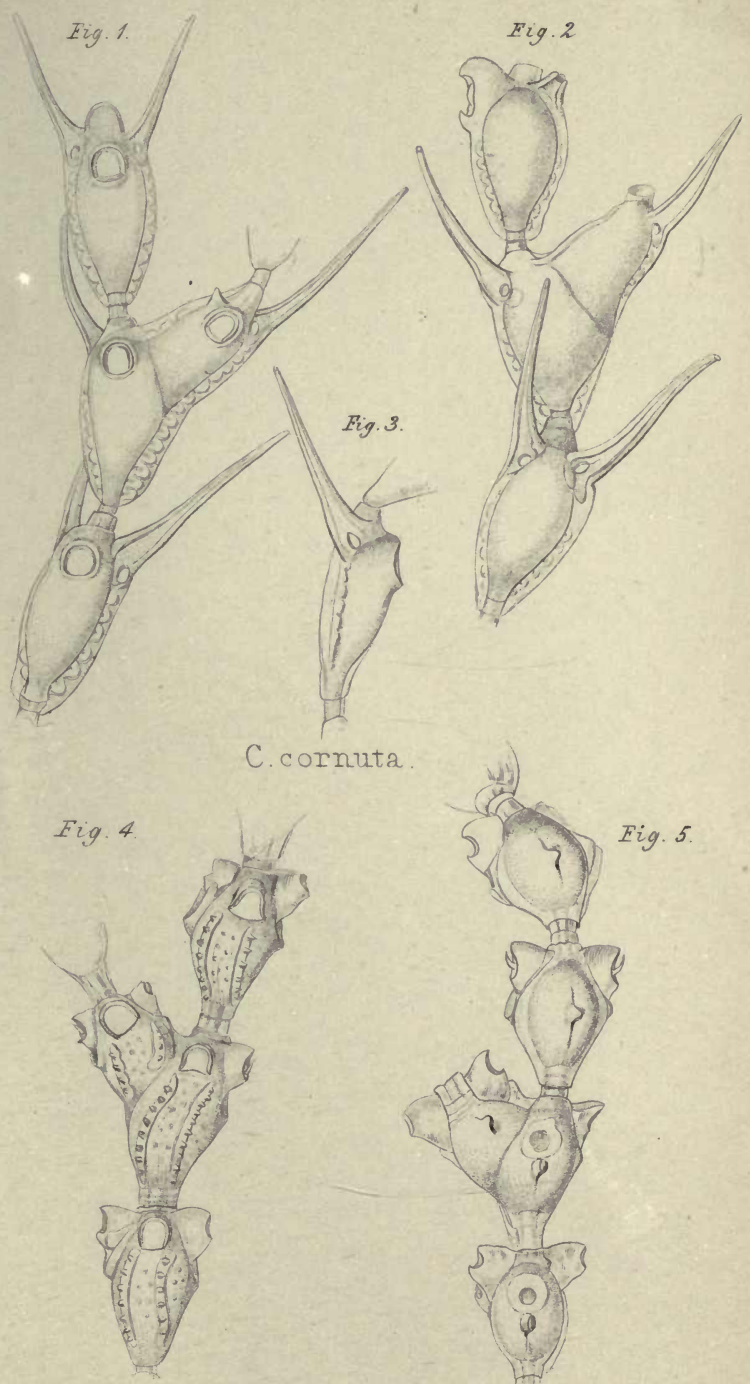

C. umbonata.

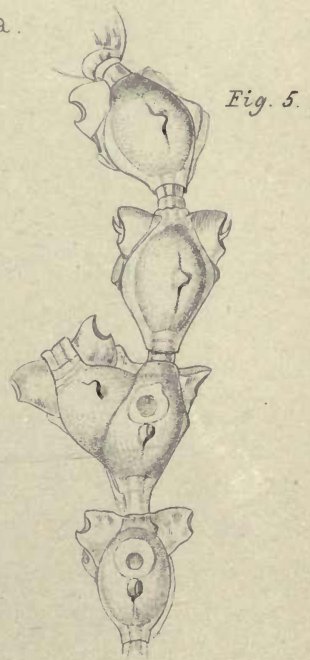

nuta. 
Fig. 1
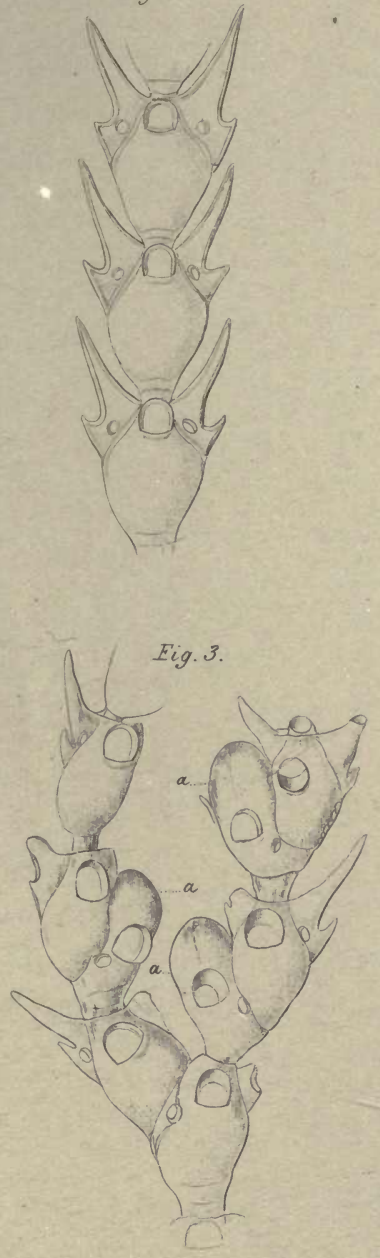

Fig 2.
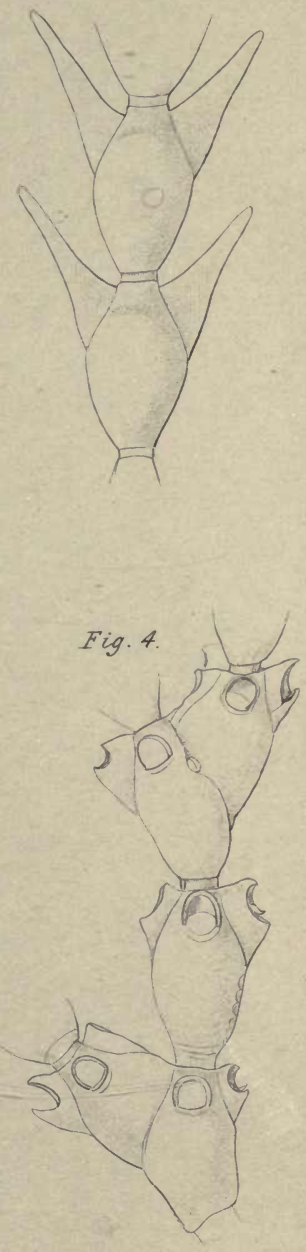

C. taurina 


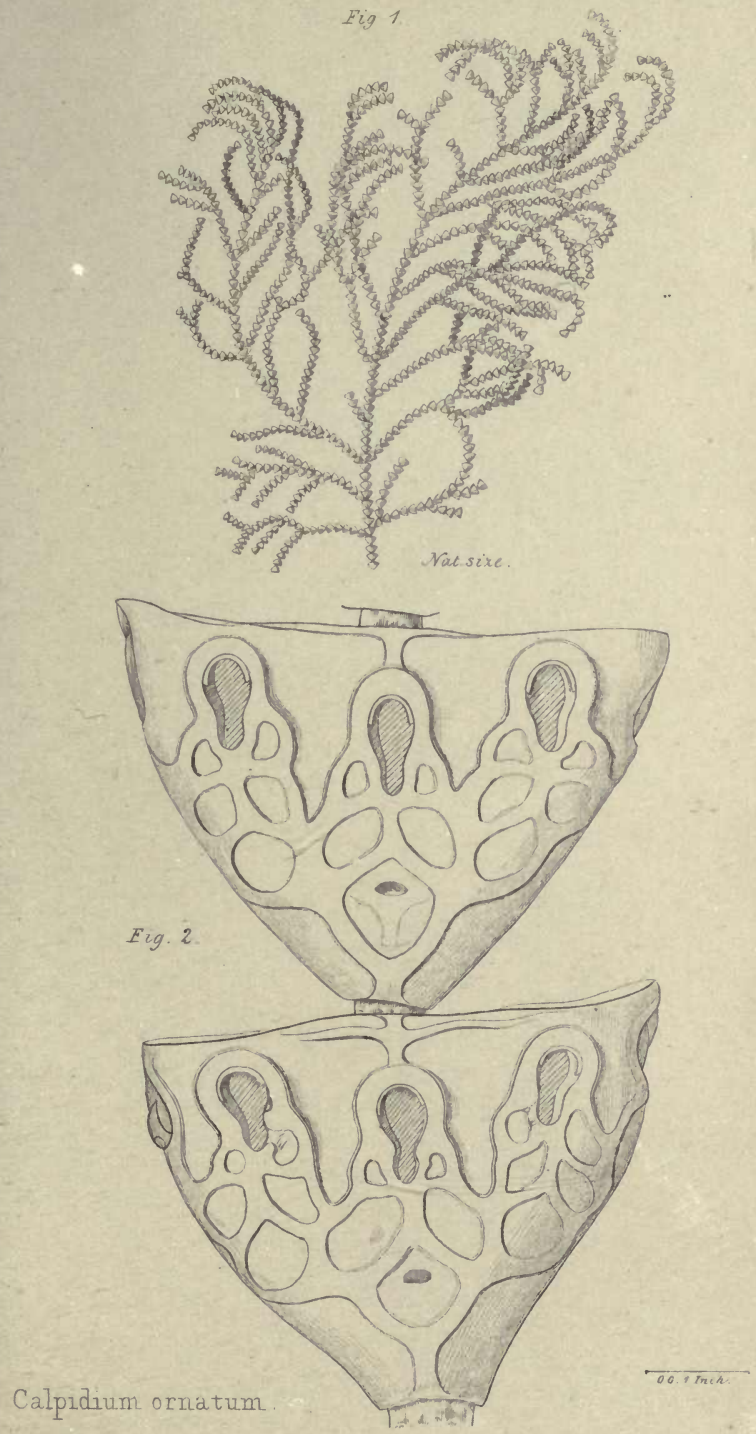



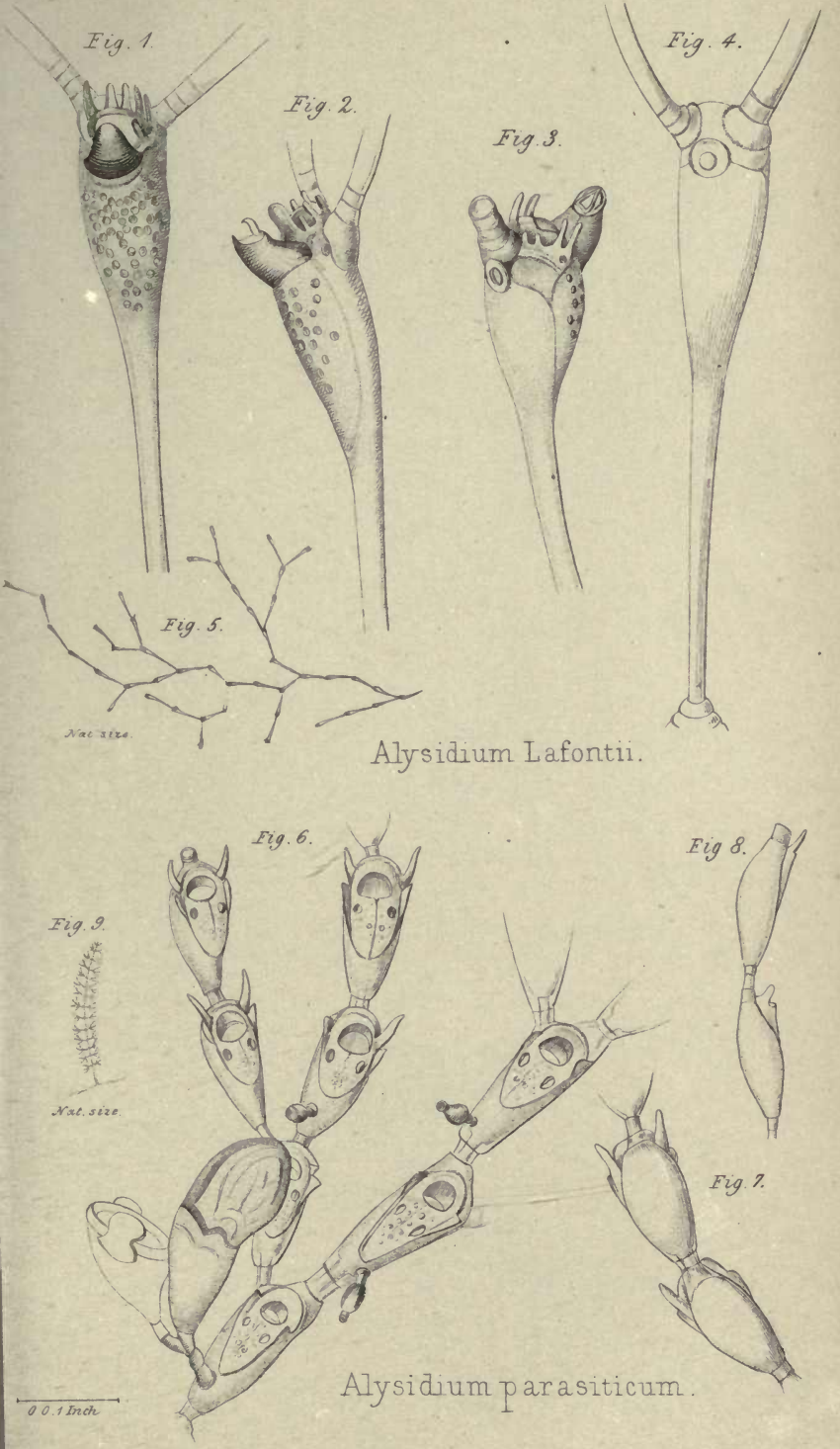


\section{Fig 1.}

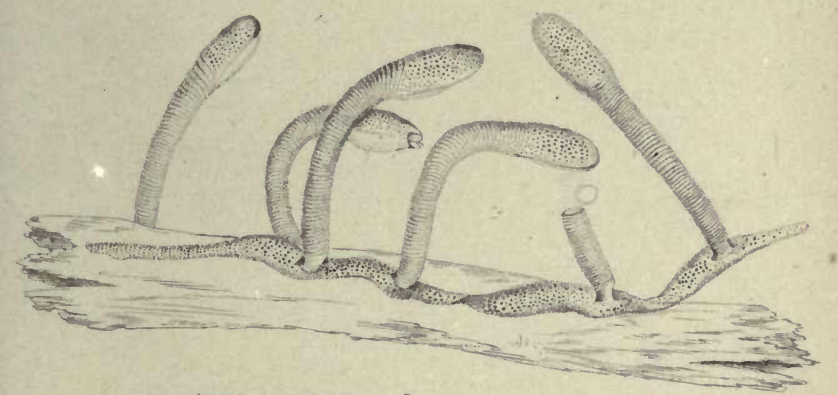

Anguinaria spatulate .
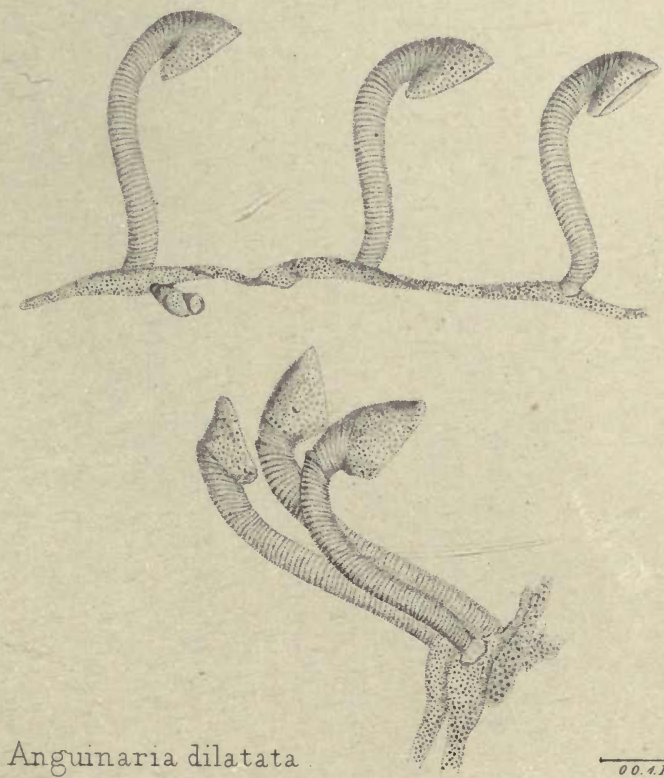

Anguinaria dilatata 


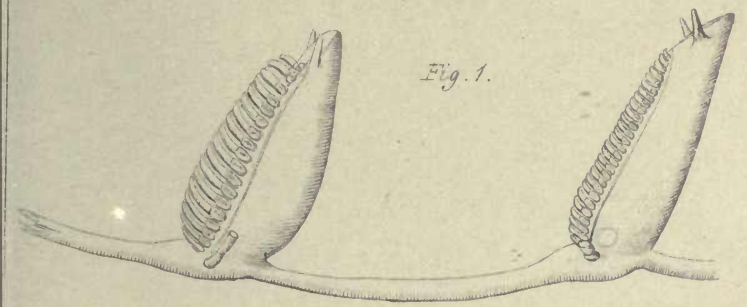

Fig. 2.

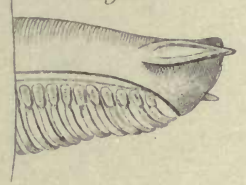

Beania australis.

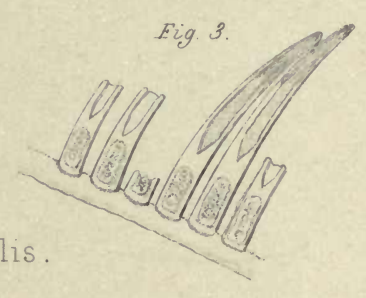

Fig. 4
Caberea zelanica.

Fig. 5.

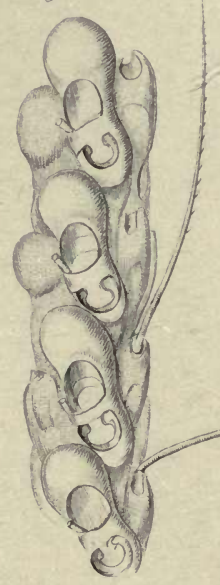

00.1 Ineh 





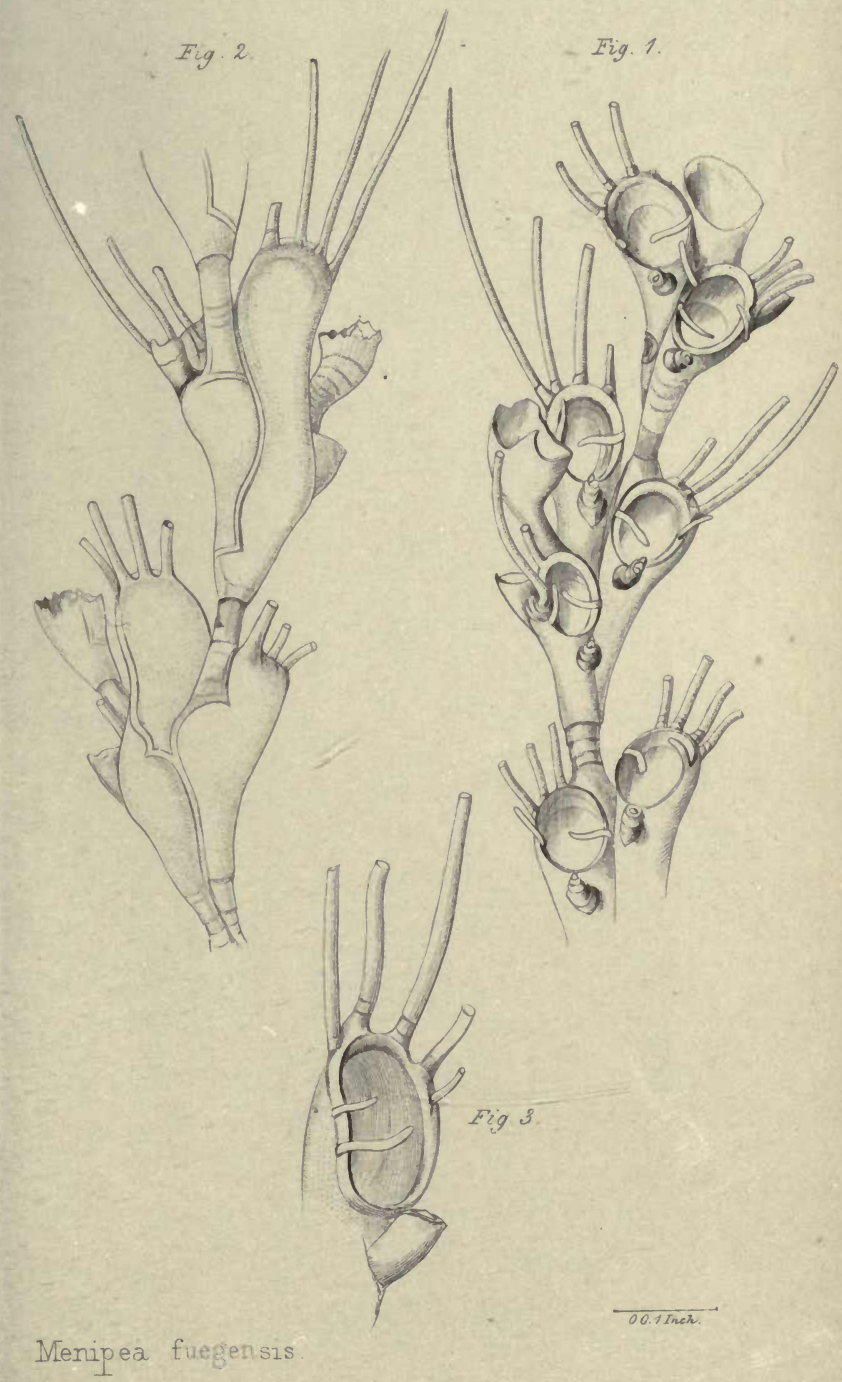





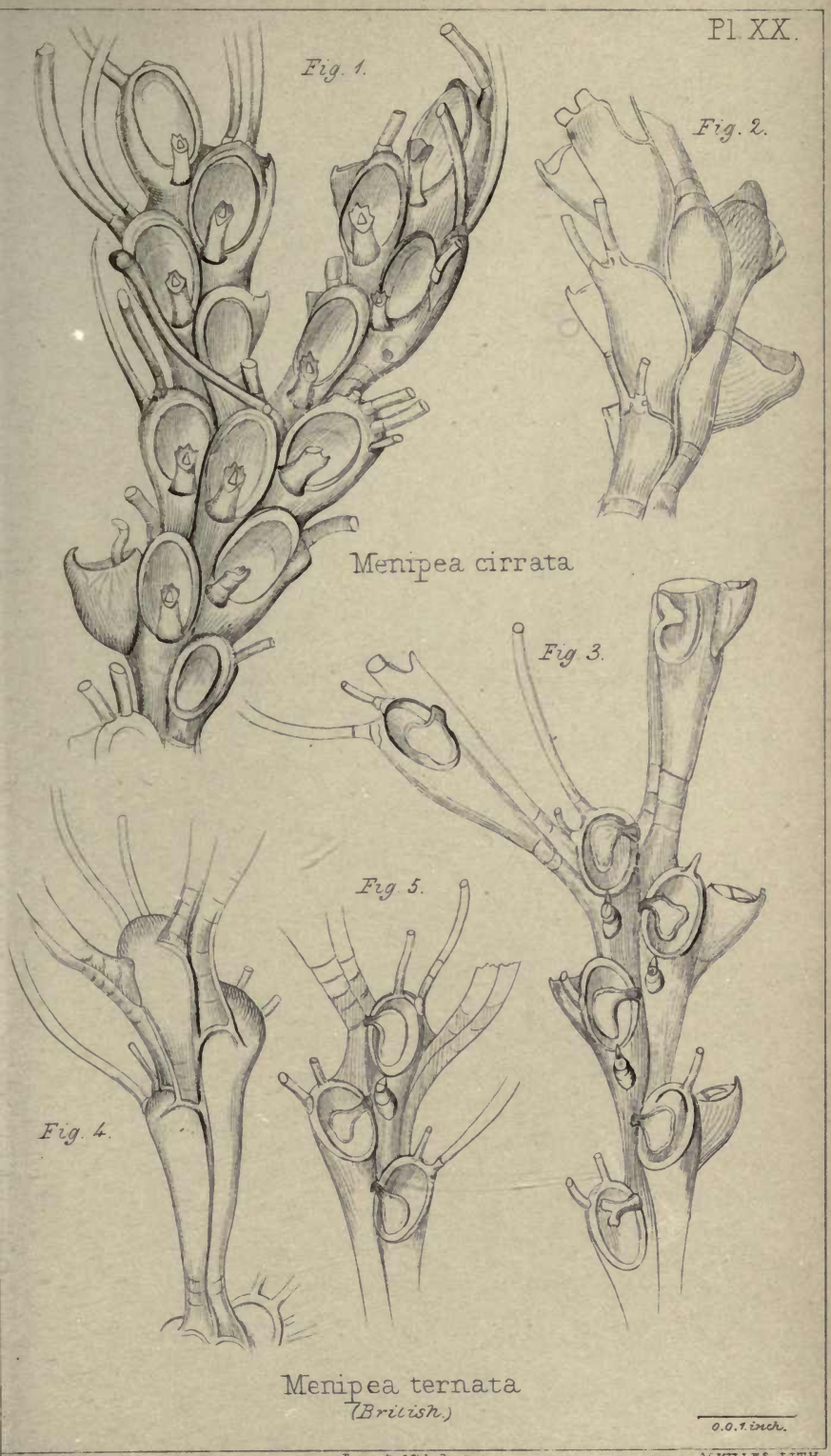





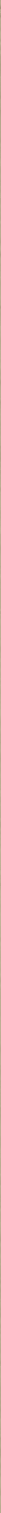





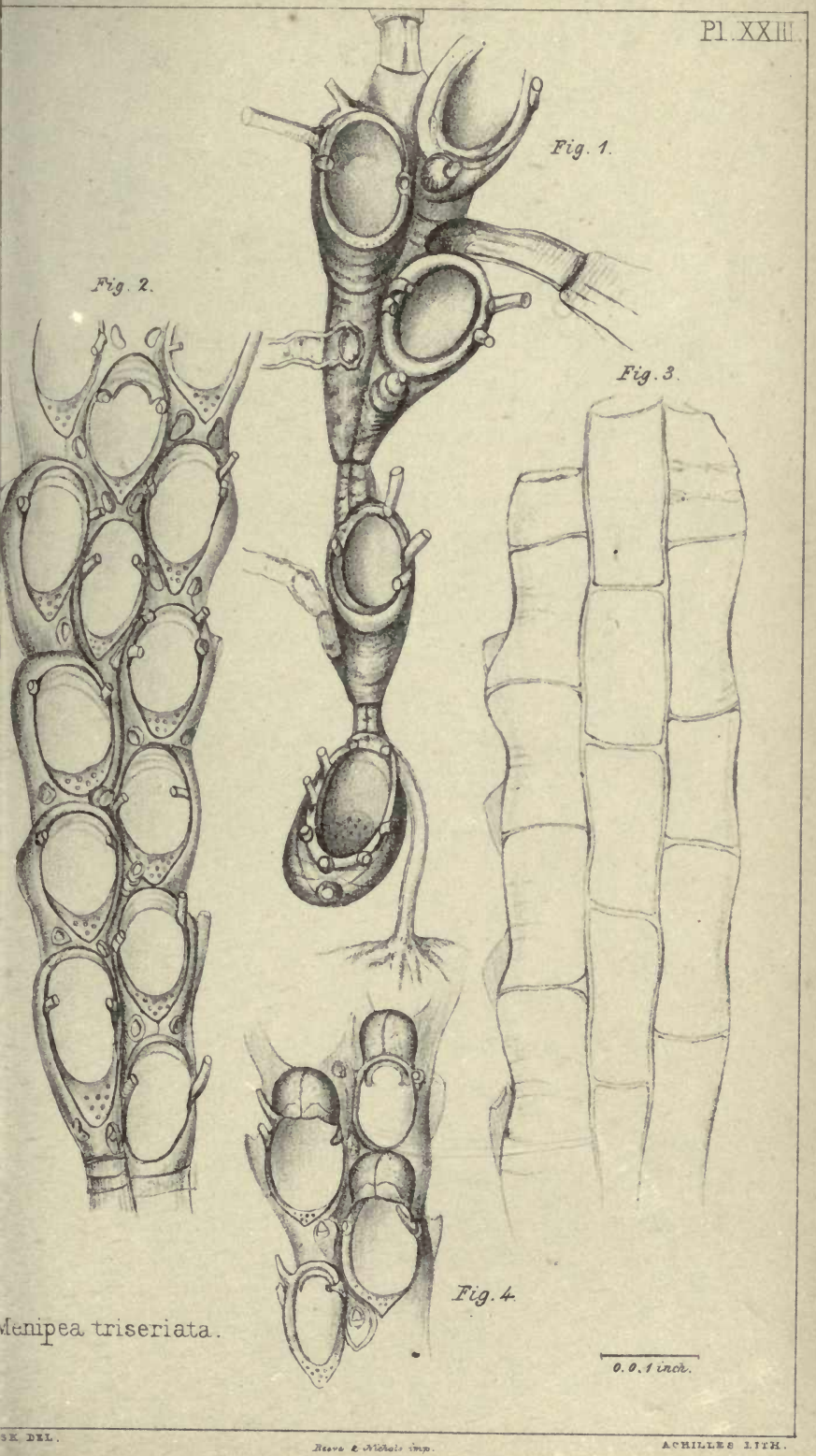




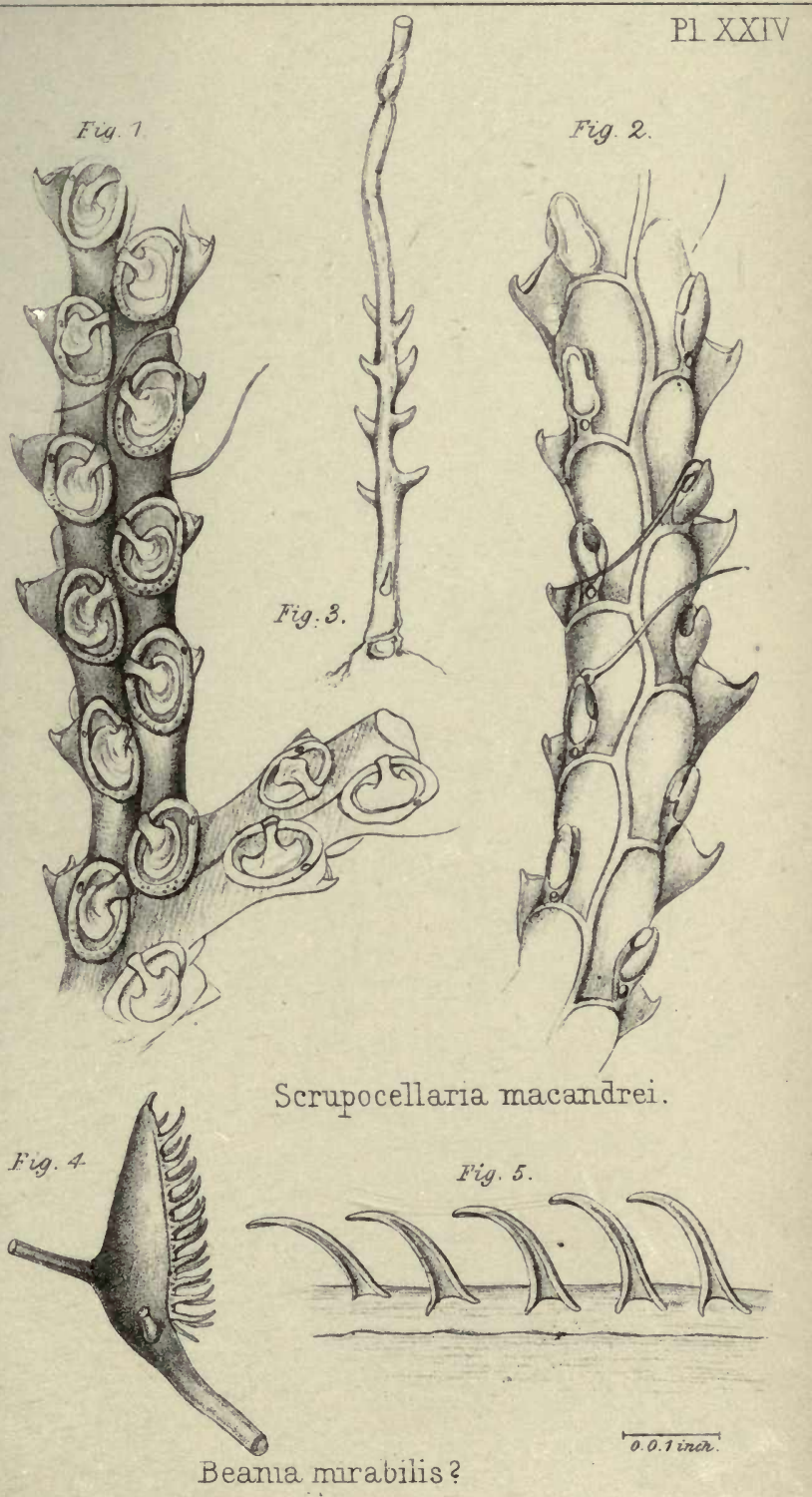

BUSK,DEI 



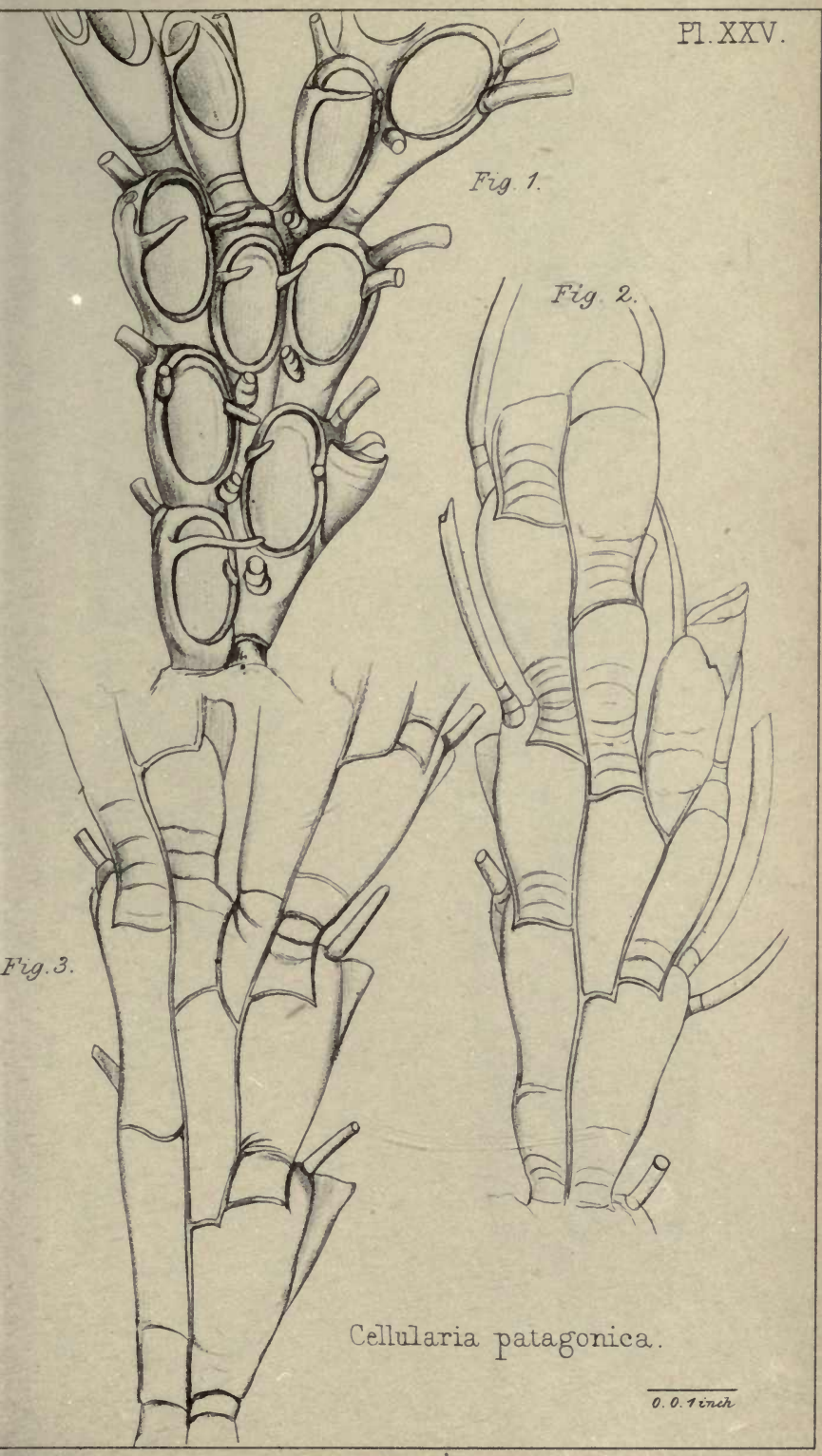

USK.DEL.

ACHILLES IITH 


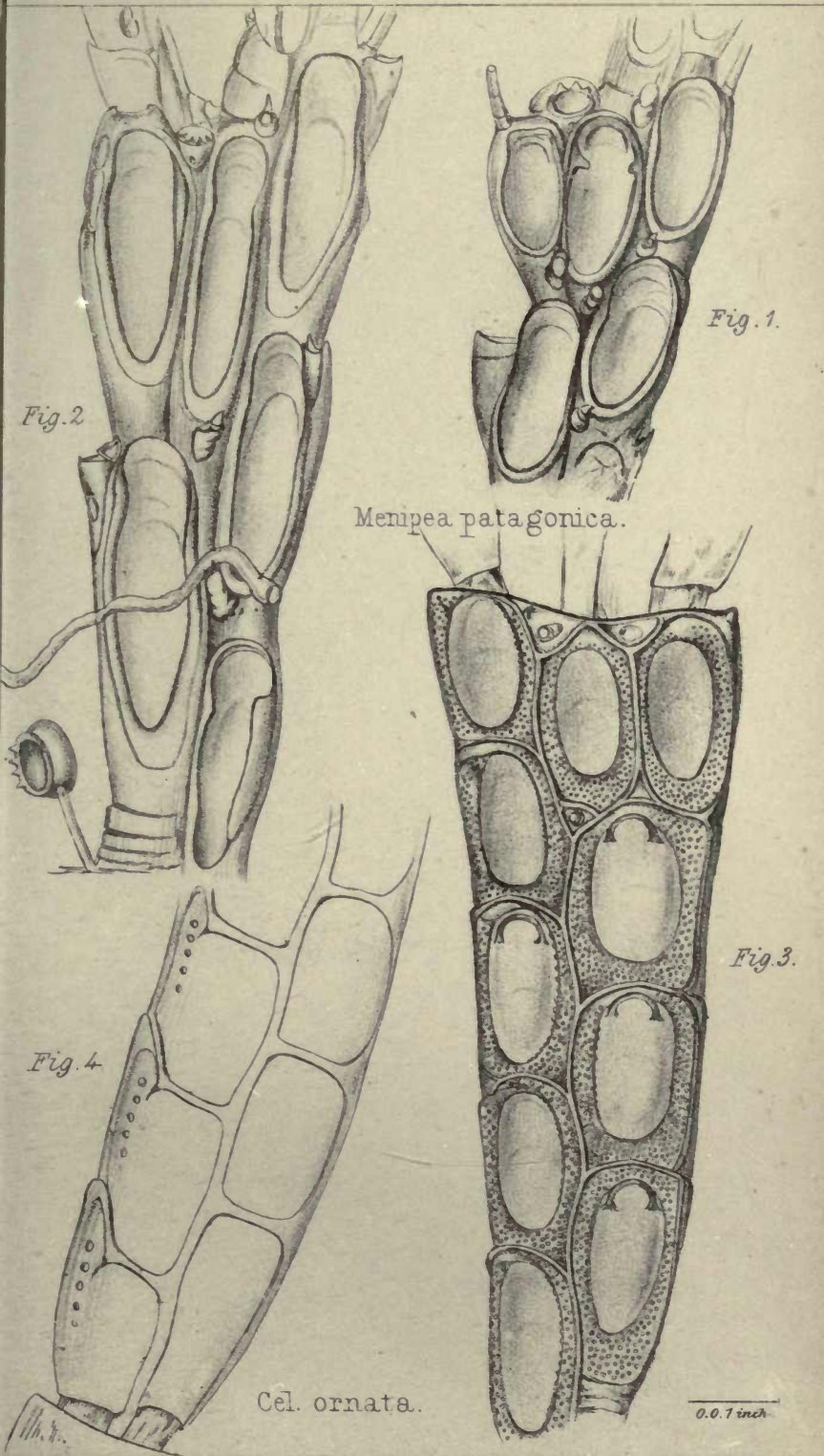


P1.XXVII.

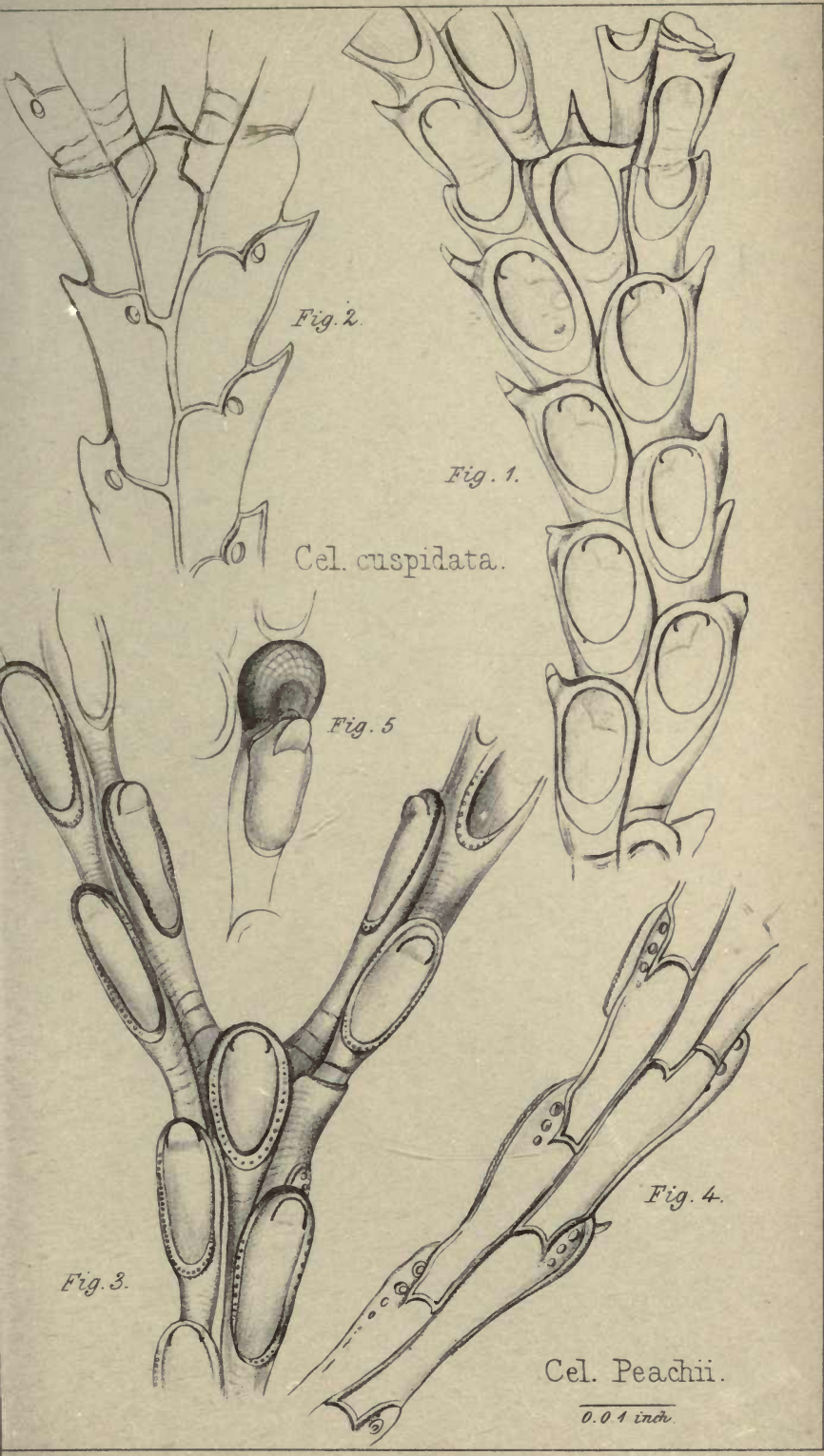

BU\& DX, DXI. 



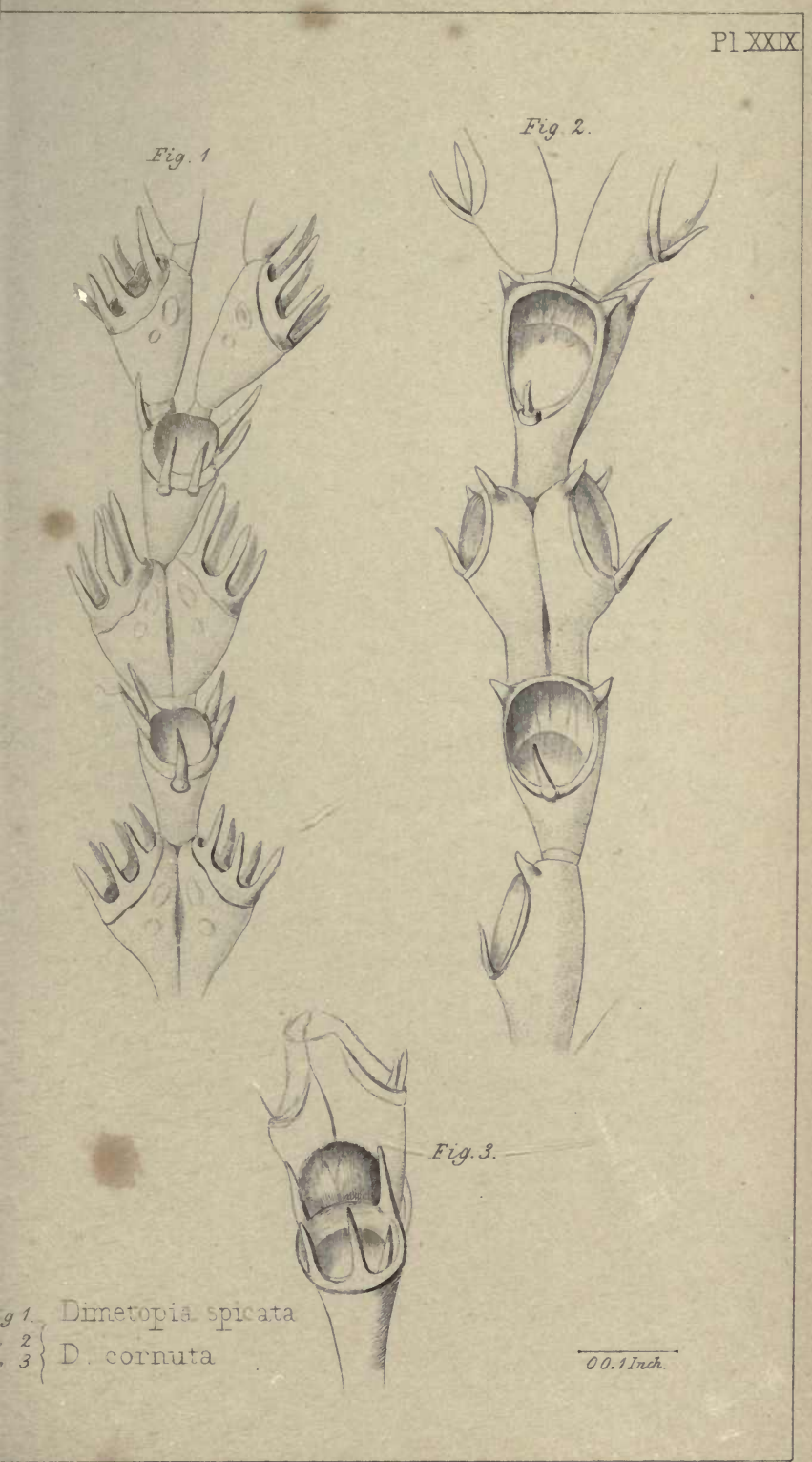





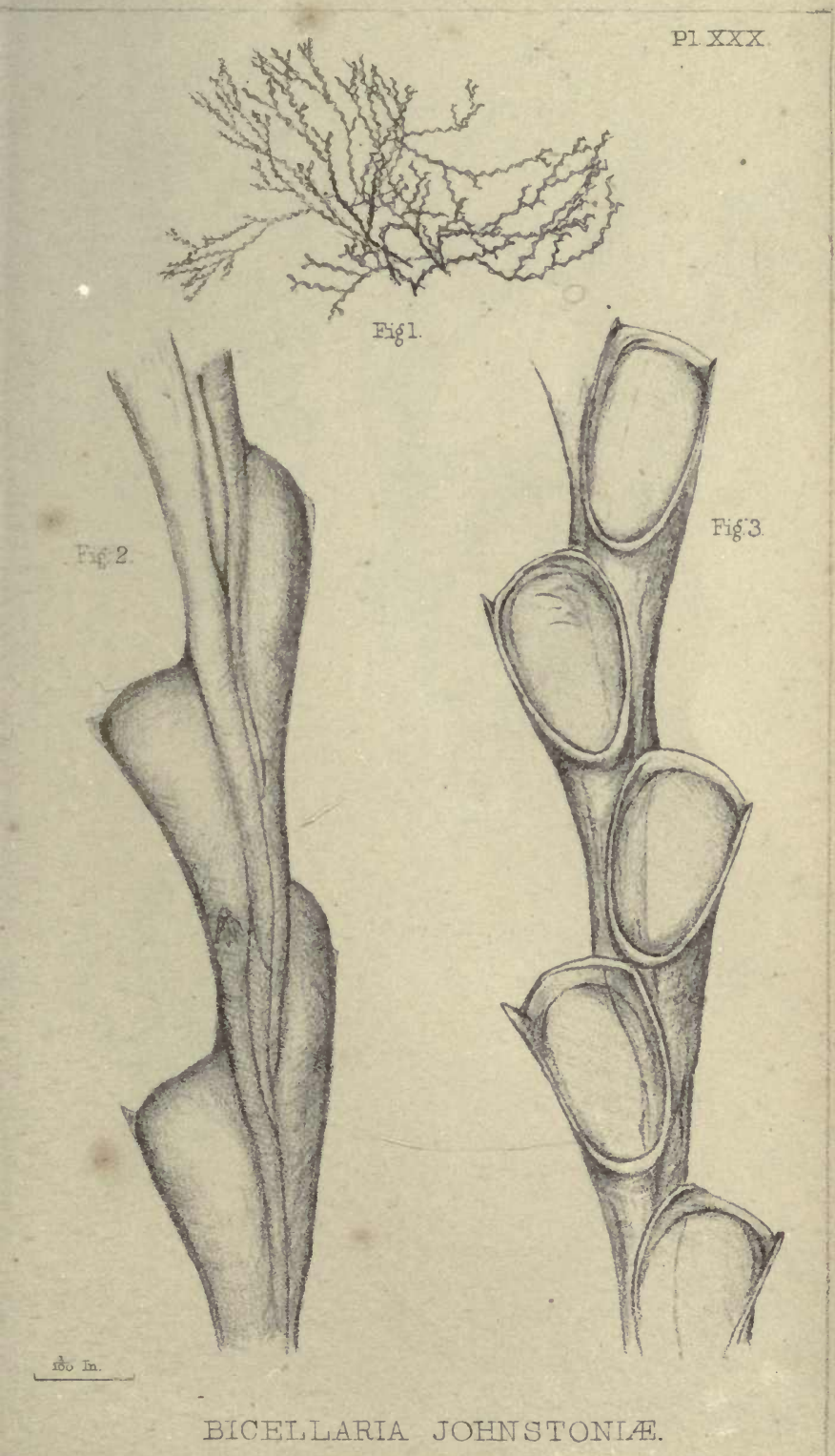






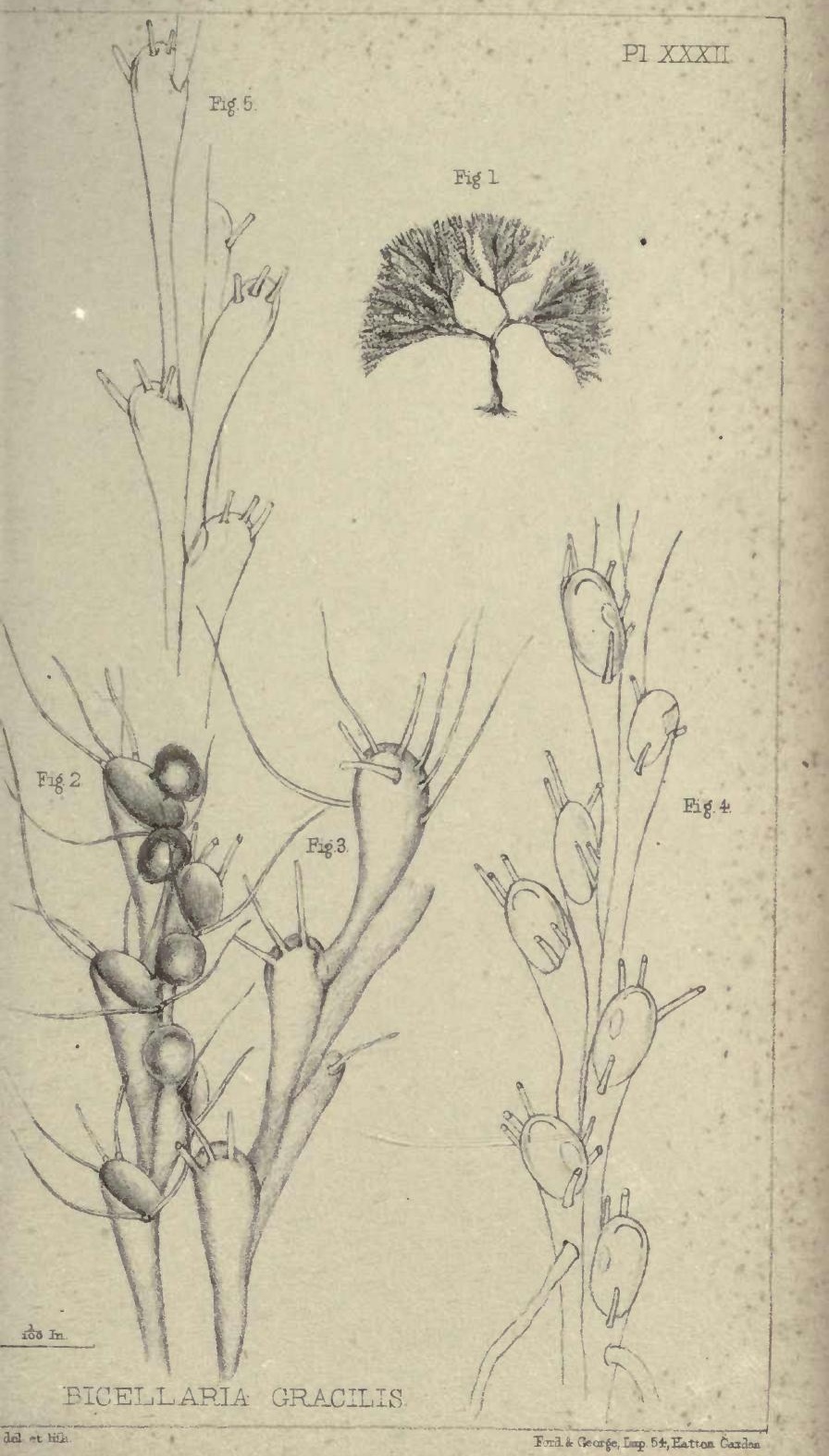





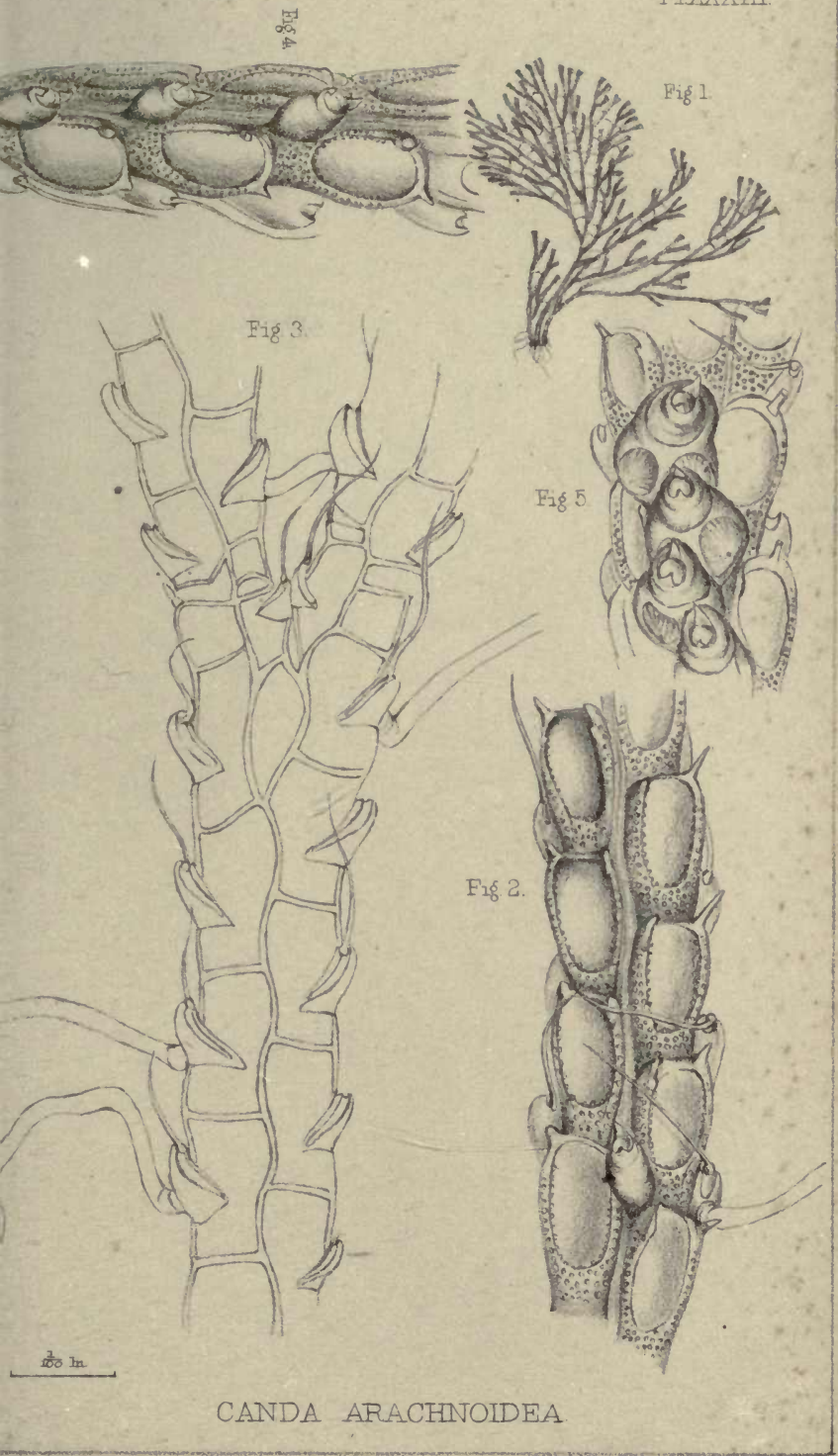





Fig. 3.

PI XXXVIL

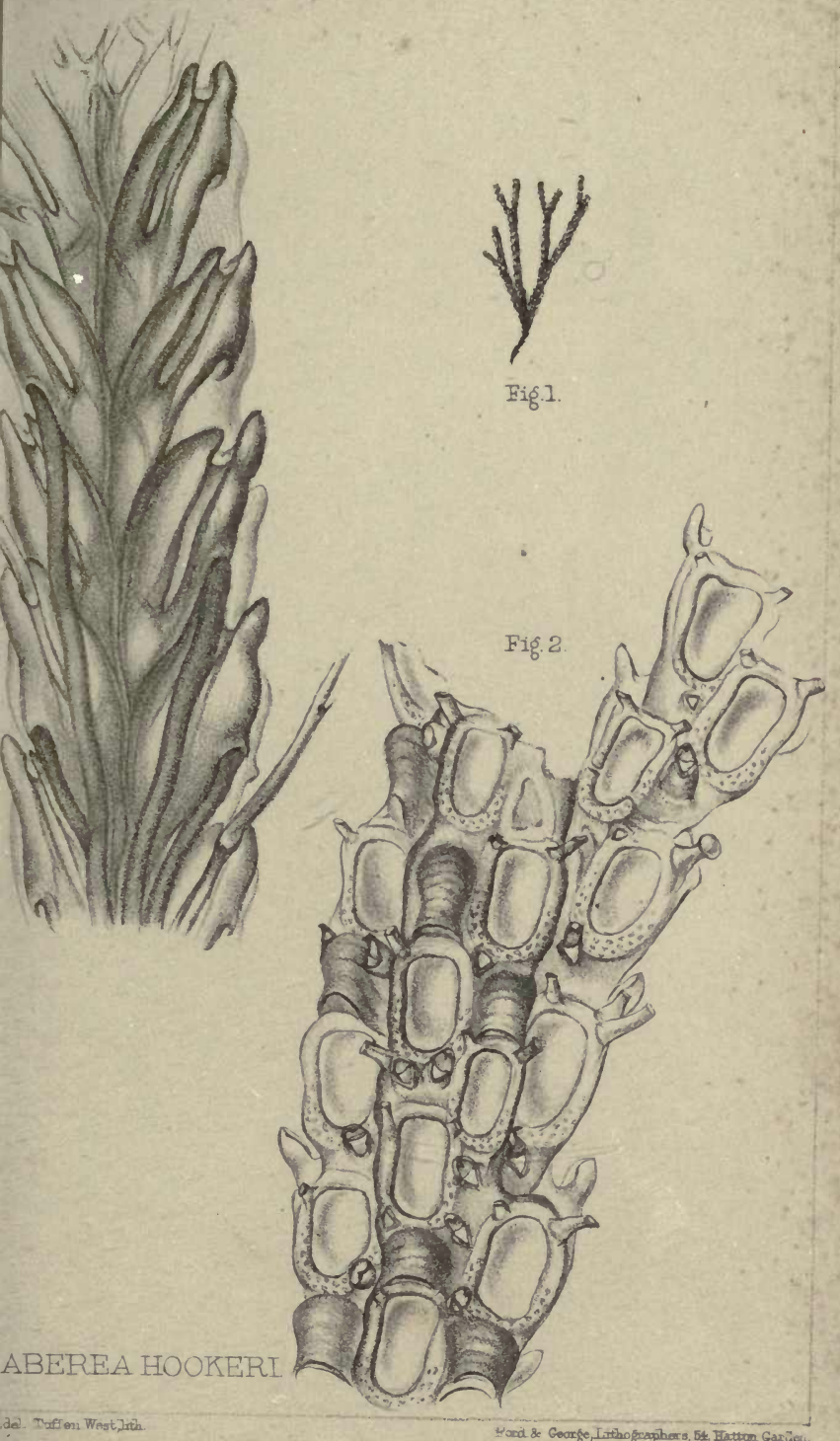





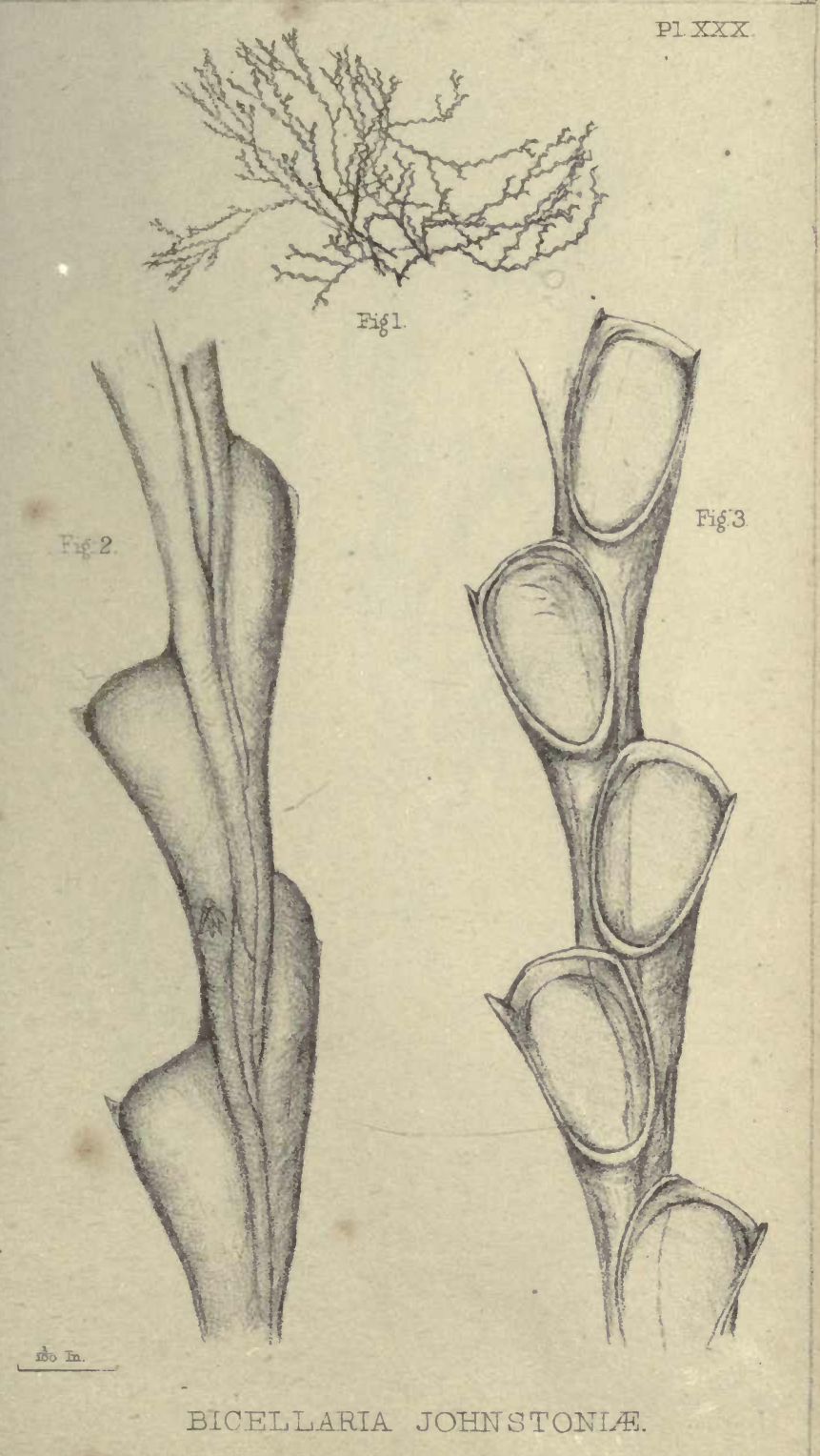






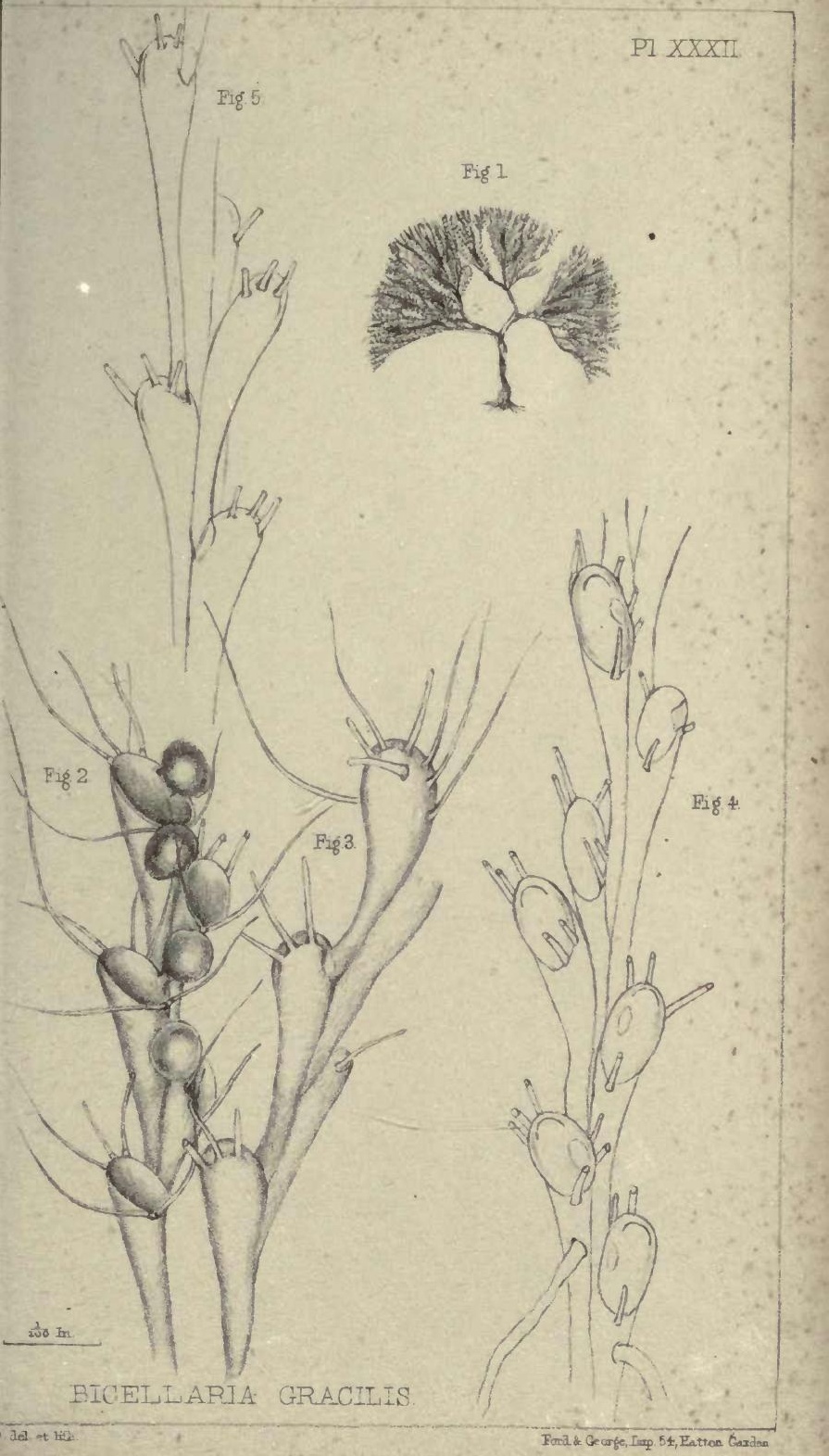





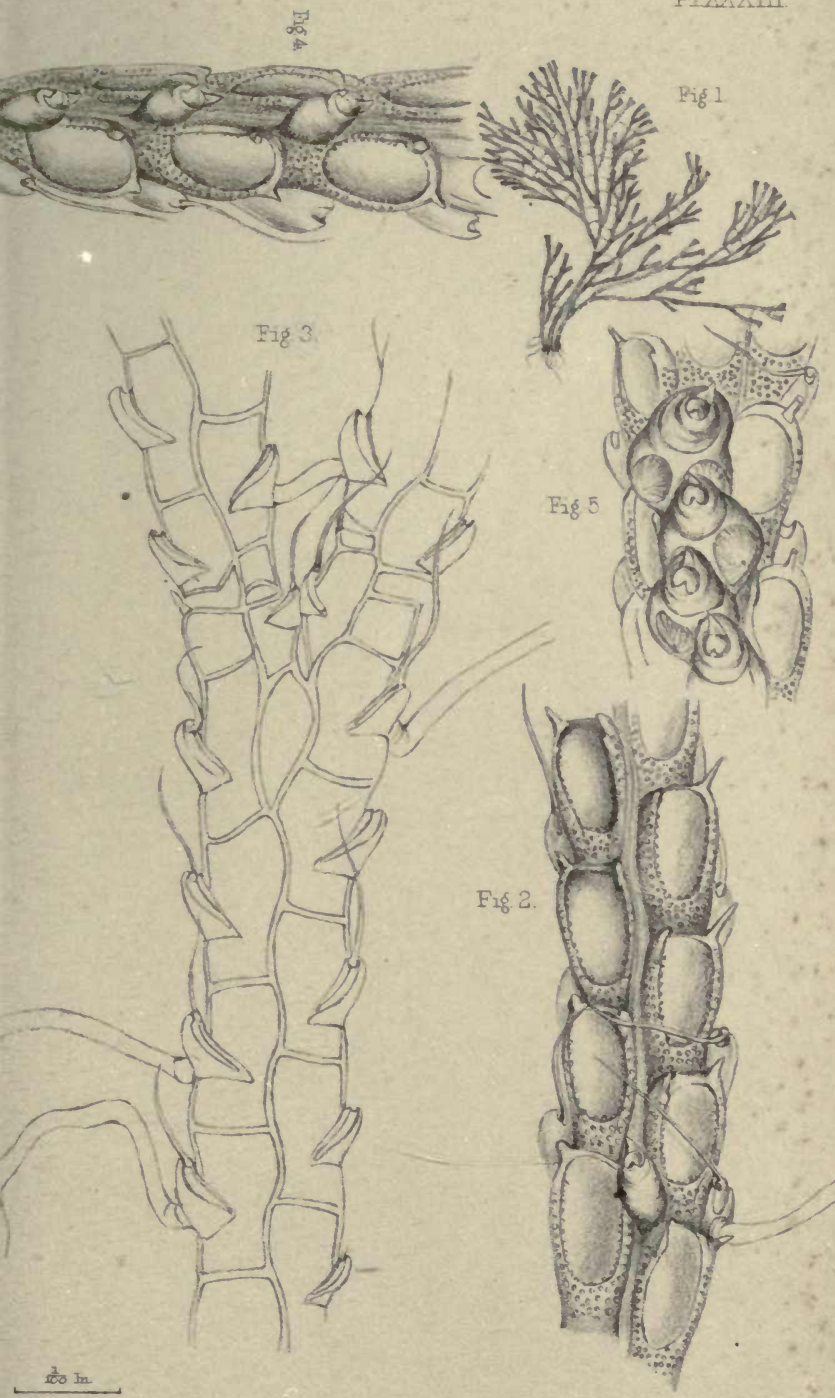

CANDA ARACHNOIDEA. 


st 

Fig. 3.

P1 XXXVIL

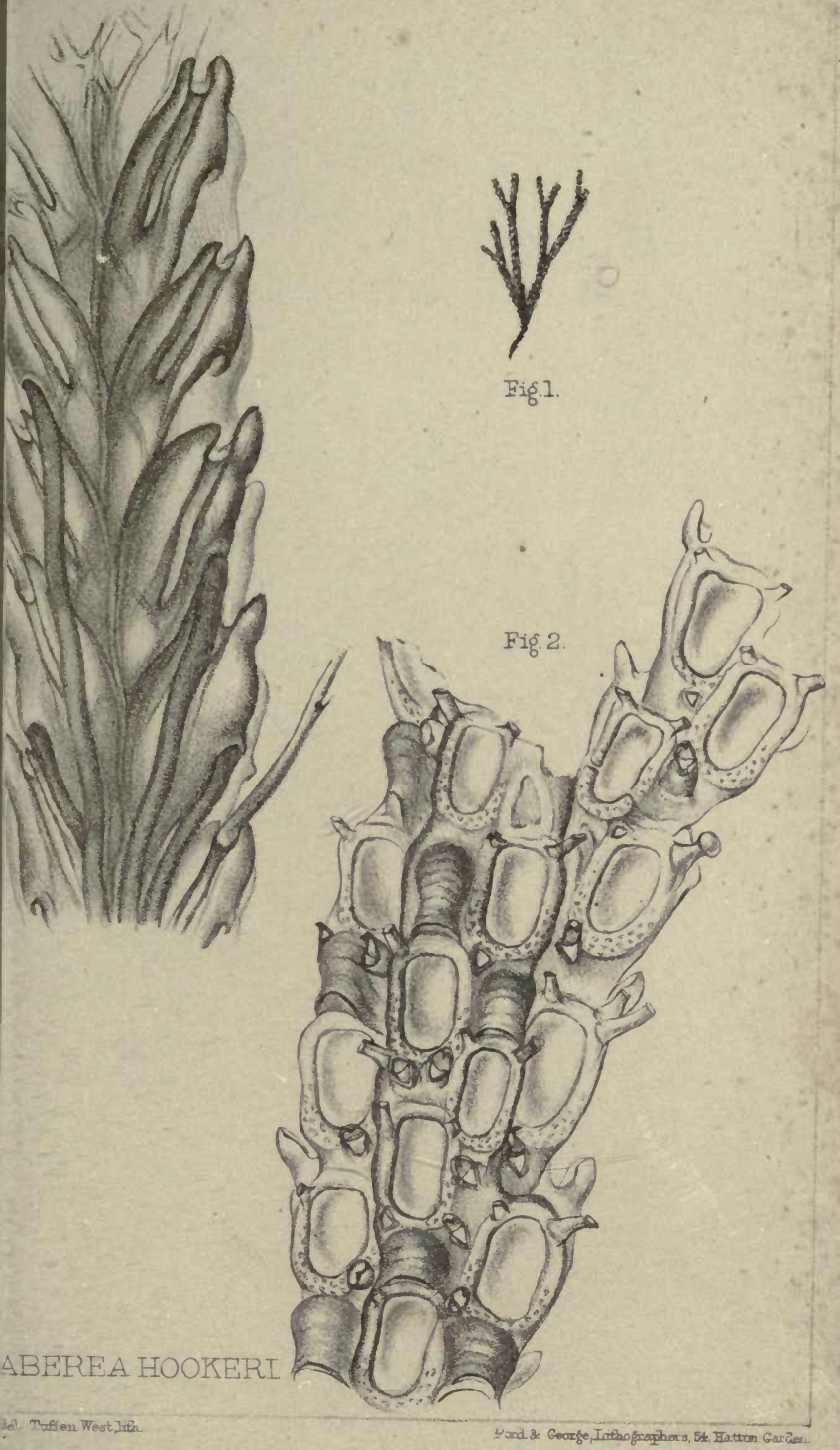





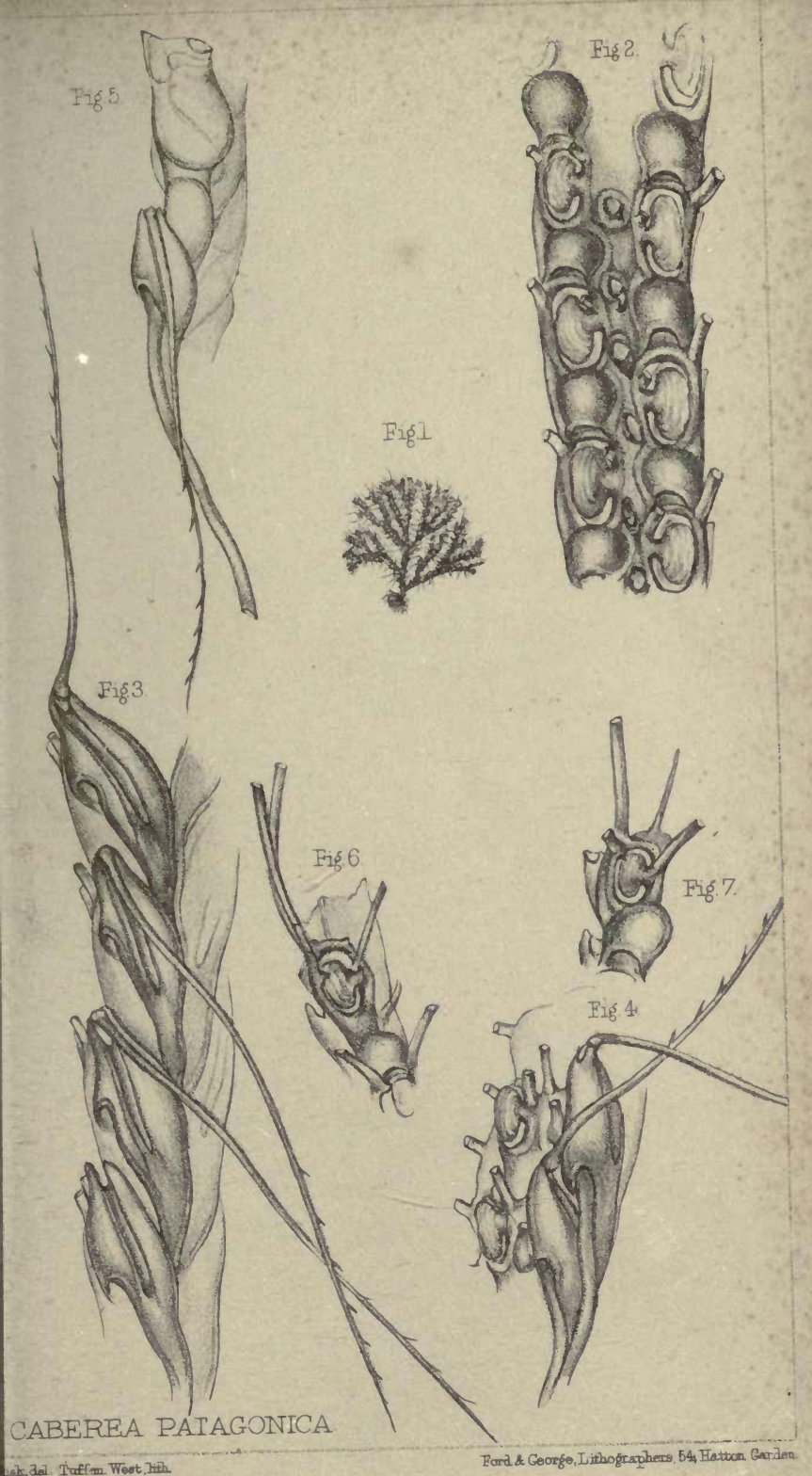




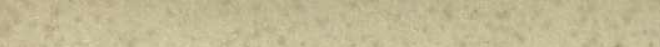

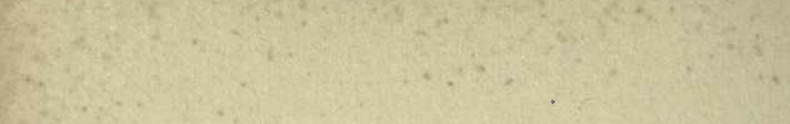

$3 x^{2}-3$

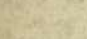

$2:$

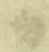

$\operatorname{lig}^{2}+4$

8: $920+2$

$45+35$

$63+46$

$2 x^{2}+(6+19=$

$\left(4 x^{3}\right)^{2}$

$y^{2} x^{2}$

wition

3. 3

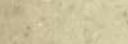

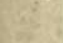

(2503)

$6 x^{2} \times x^{2} \cdot$

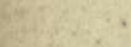

$\cos ^{2}+300^{3}$

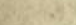

16y.

2.1.2

46xis:

$+4 y+2 y+1$

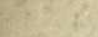

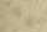

$x^{3} y^{2}=$

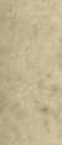

$\frac{3}{4}+3=$

87 


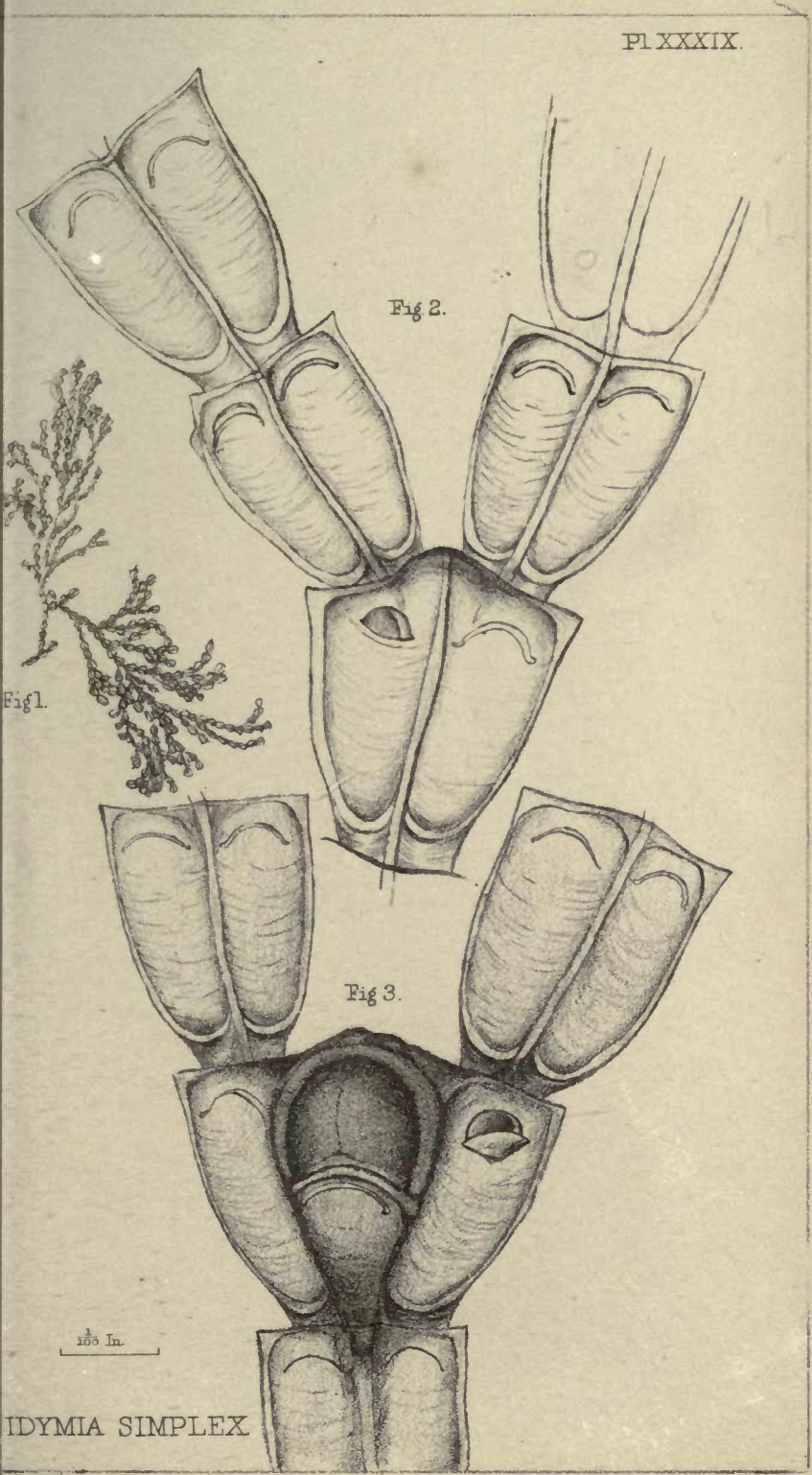




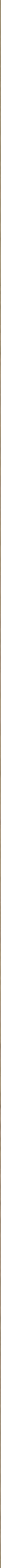


$-x^{2}+y^{5}$

a

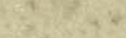

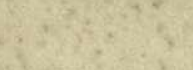

$6+2=2 x+2 y$

$4+2 x+2$

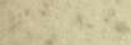

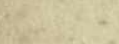

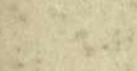

$+35 \times 28$

8xis

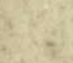

356

t $54-3$

Exy-1.

(4-x)

$6 y^{2}+2 x+2 x$

$\log +2,2$

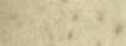

wit $+2 s$

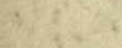

$x^{2} x^{7}=$

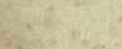

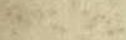

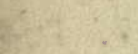

$3 x^{2}+1$

$625 x+4,7$

$x^{2}+3=28$

$y^{5}=3+2$

6.

(1) $x^{2}+x^{2}$

2.tily

$45+4=$

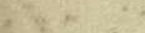

intis 


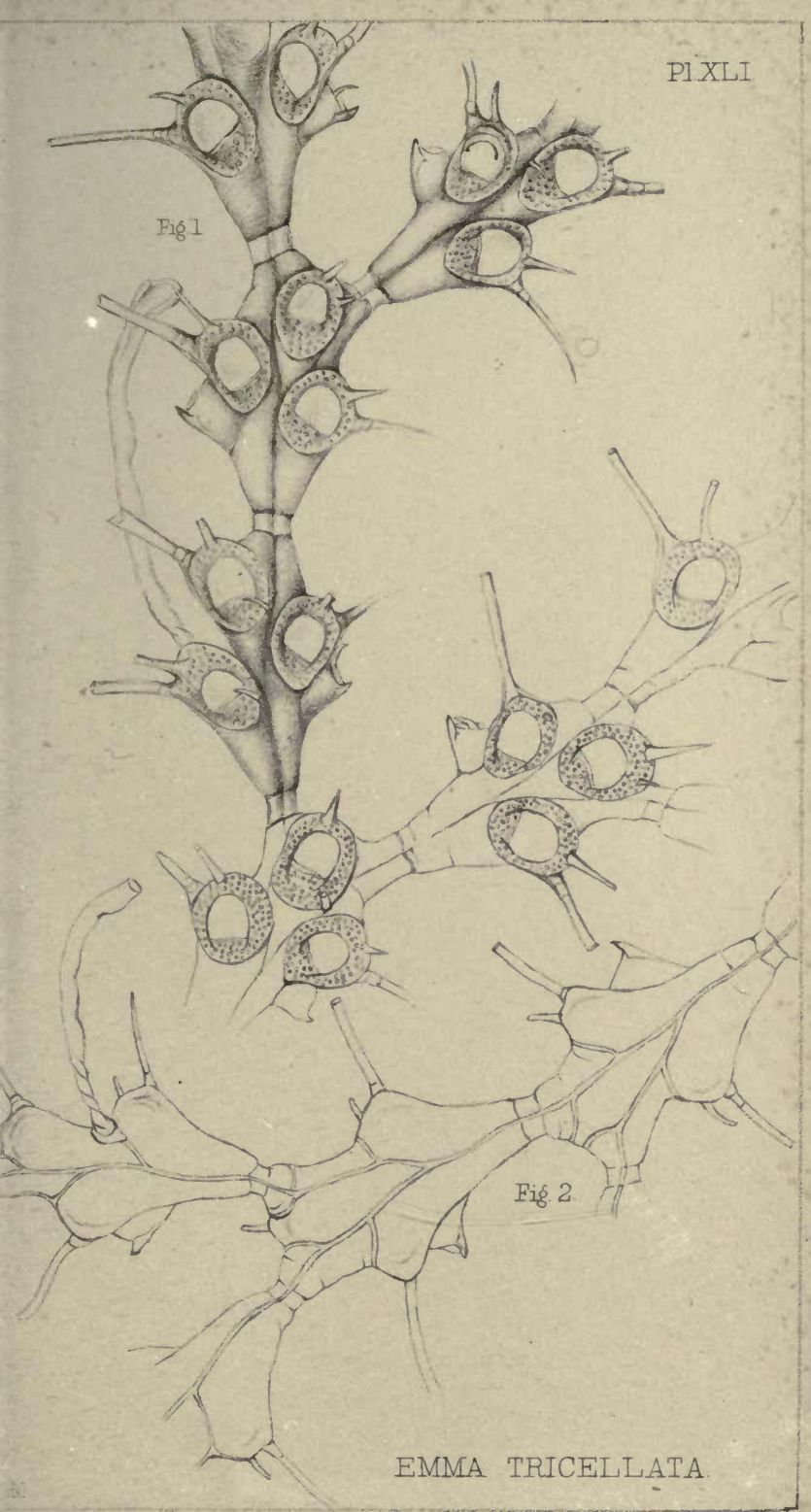





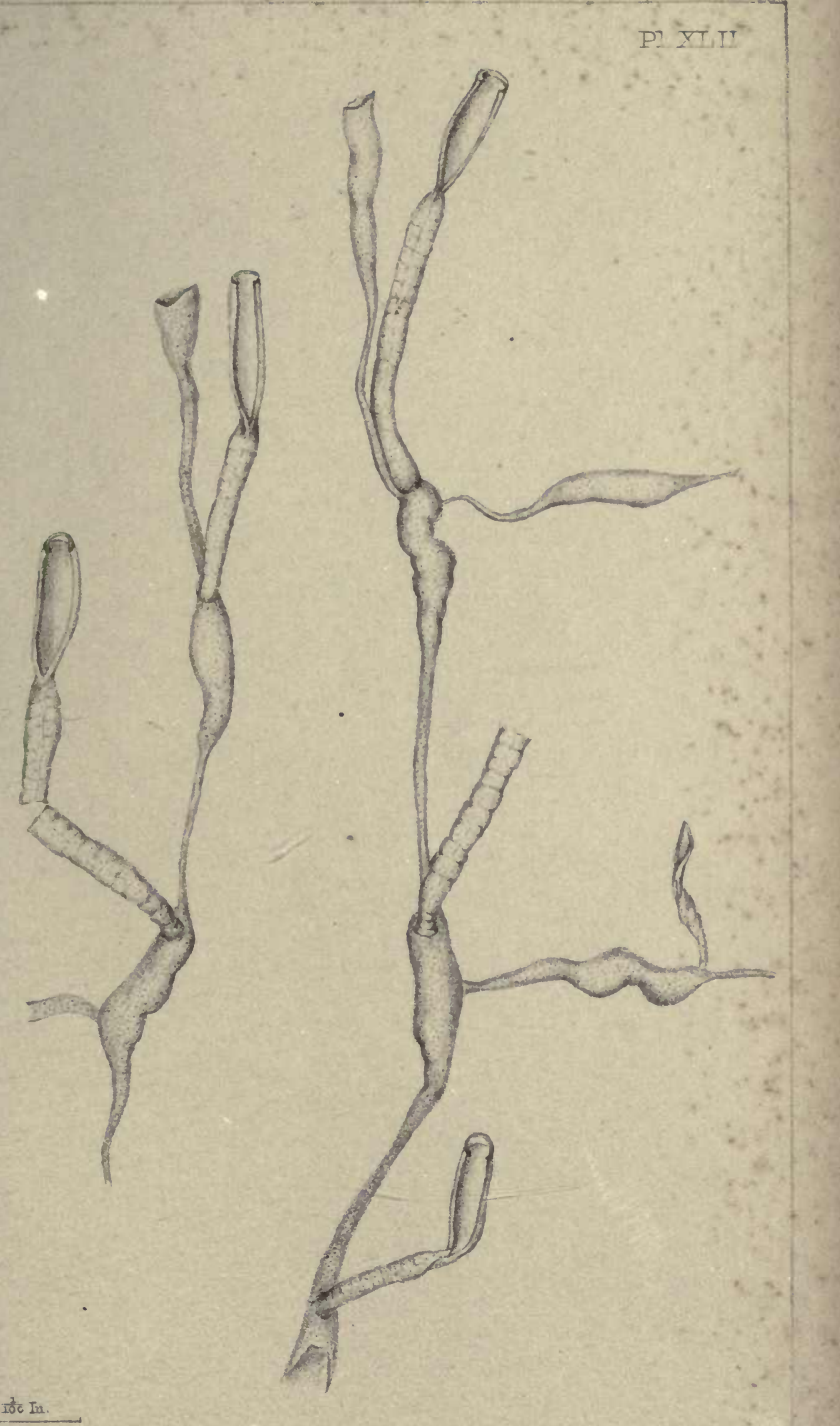

ANGUINARIA LIGULATA

2 da et JFfh

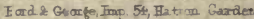





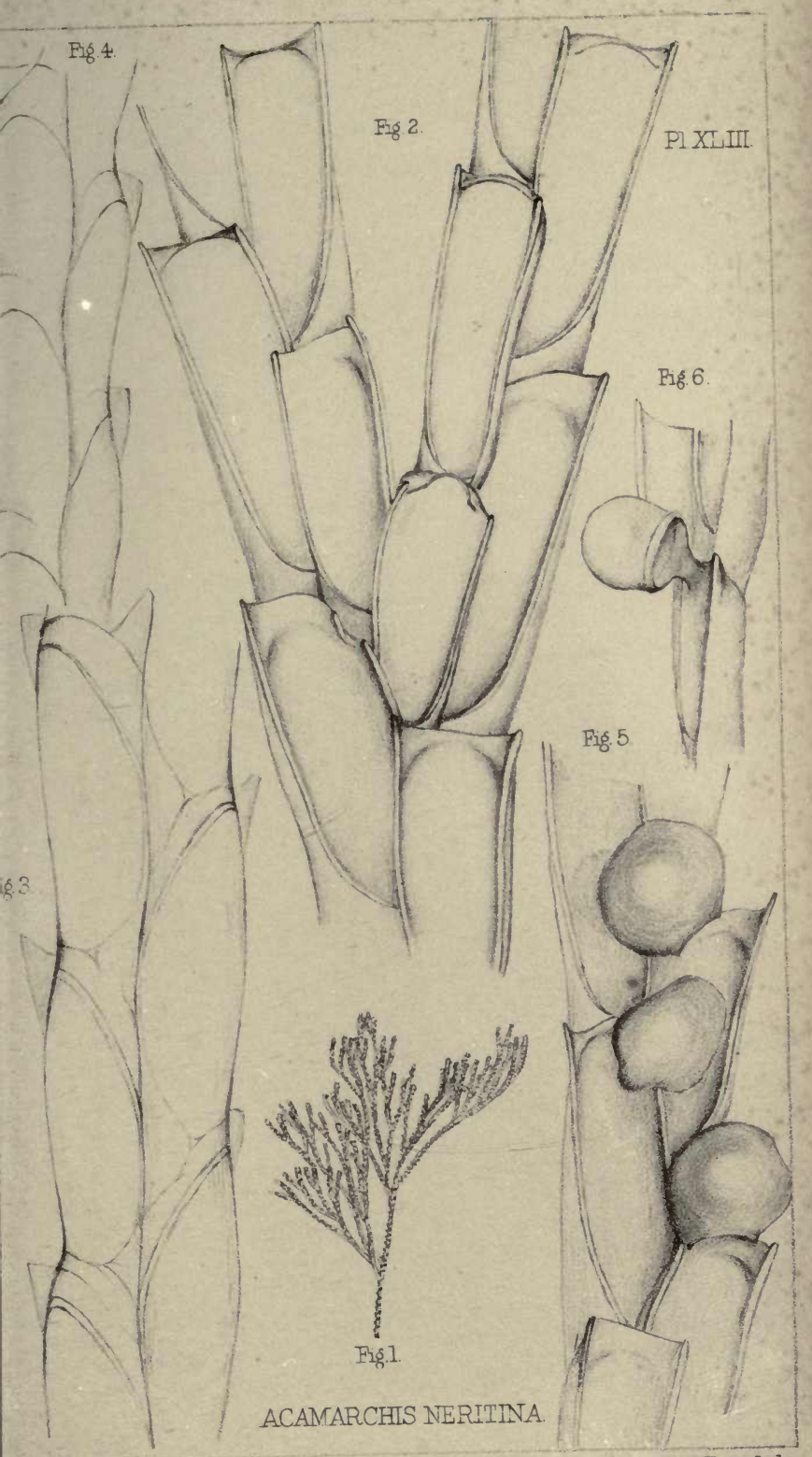





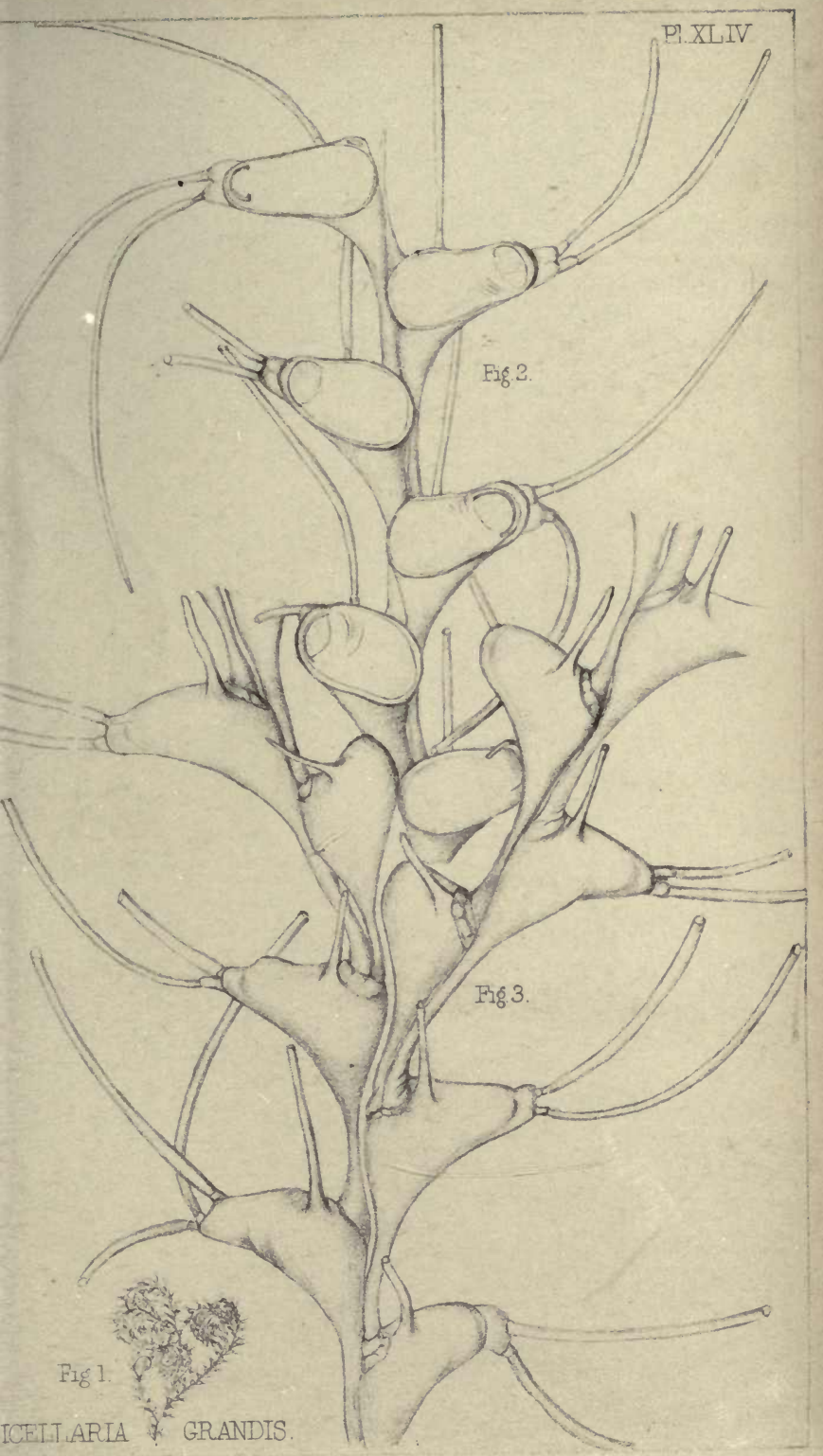





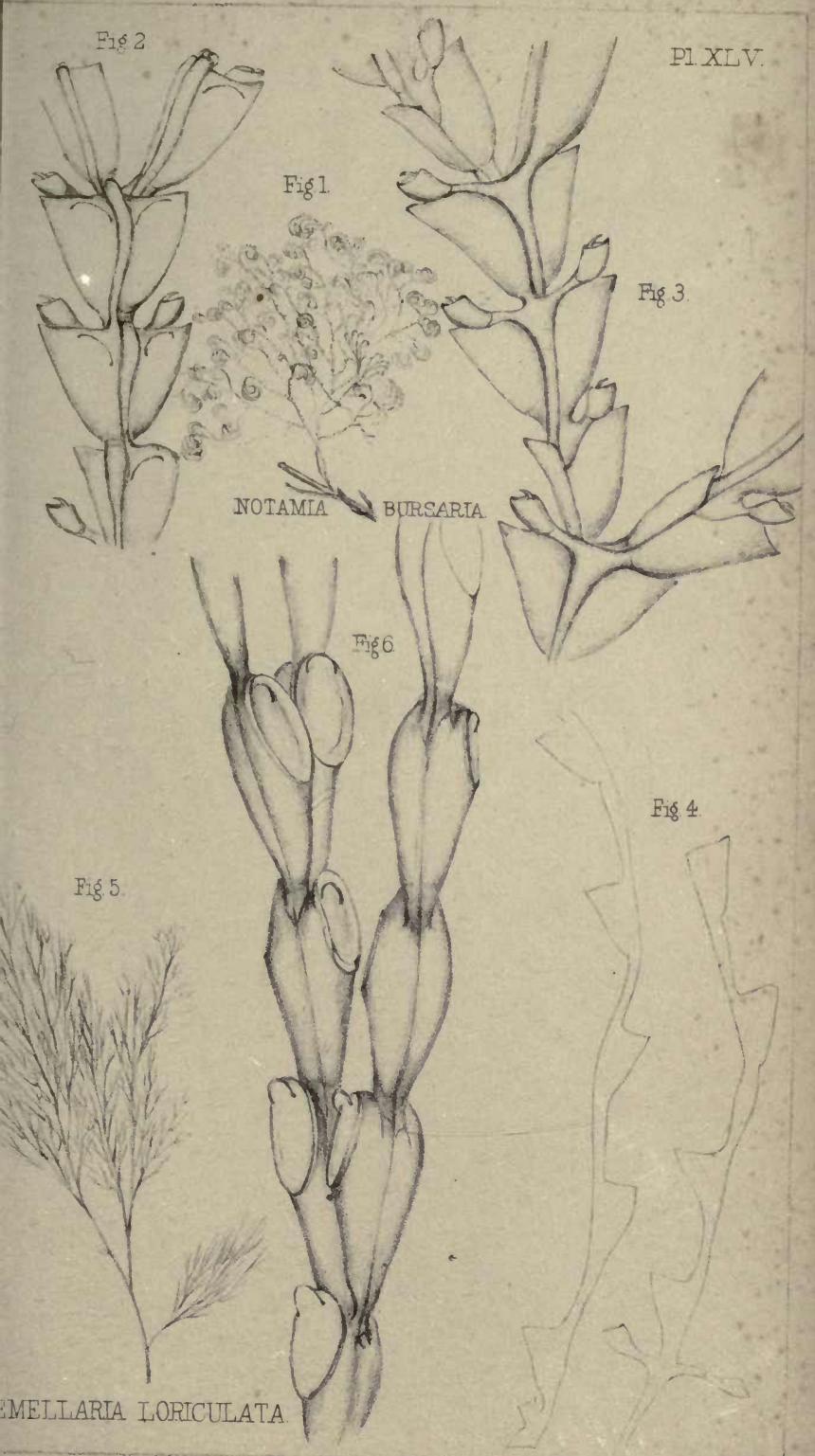





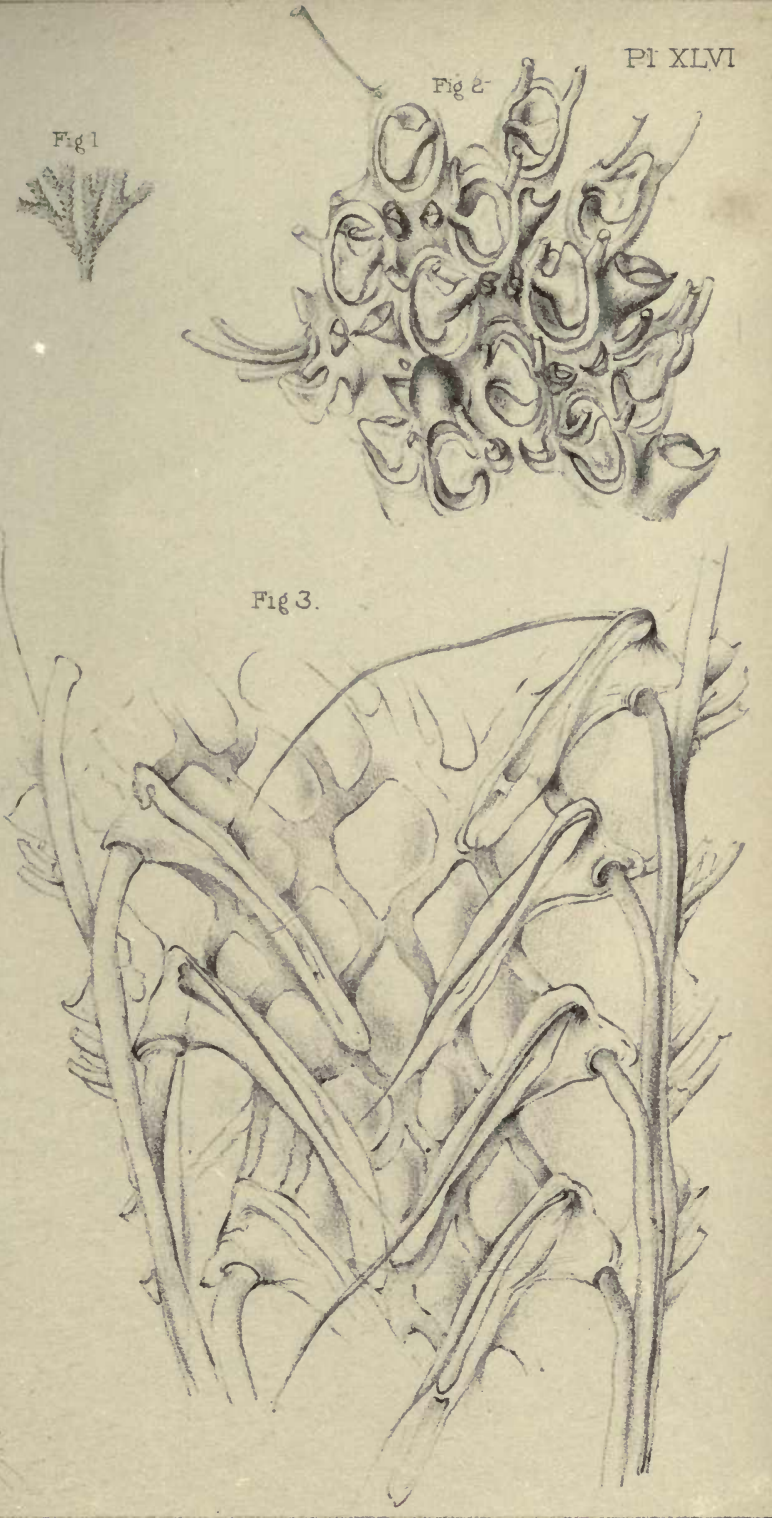





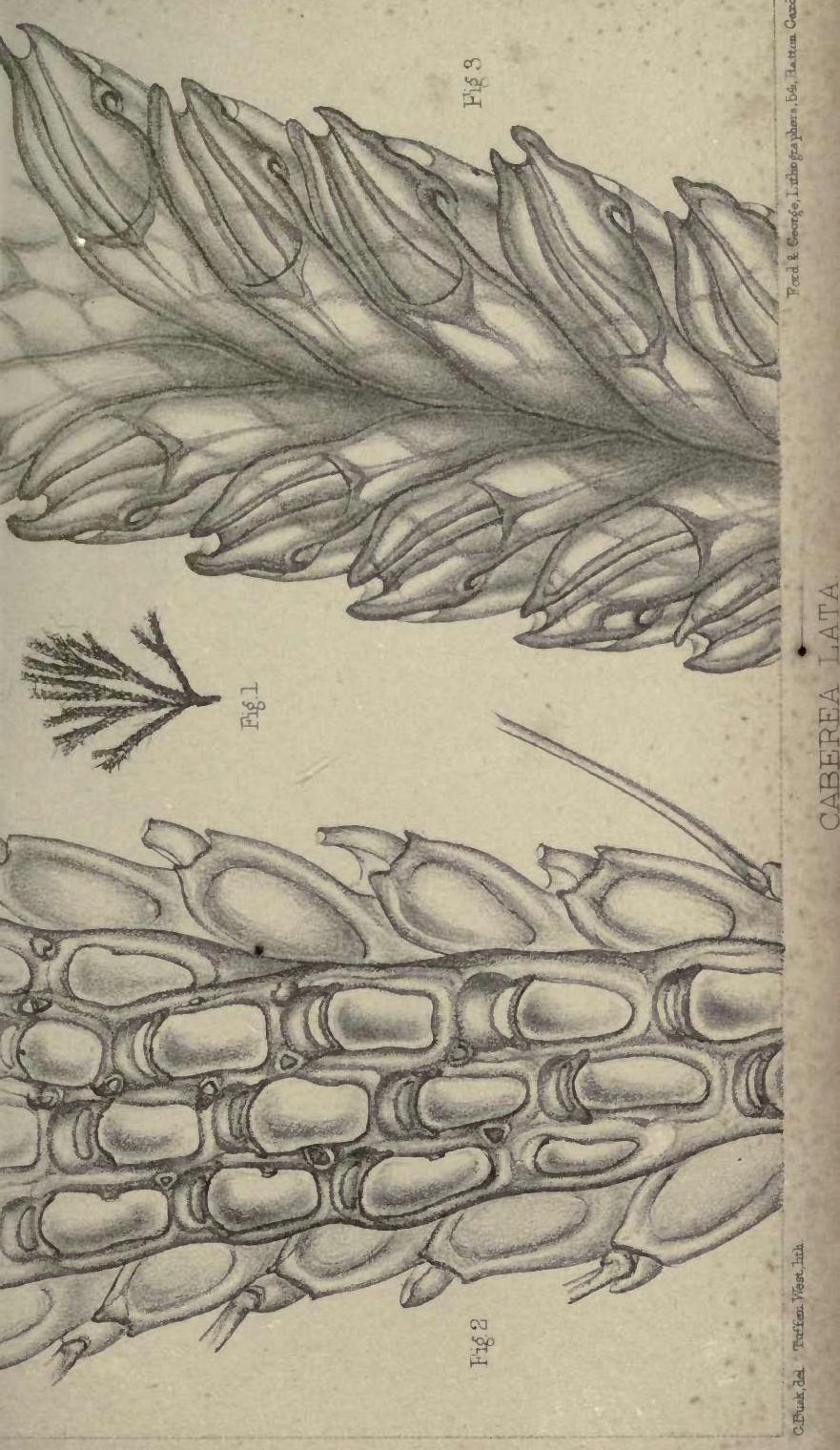




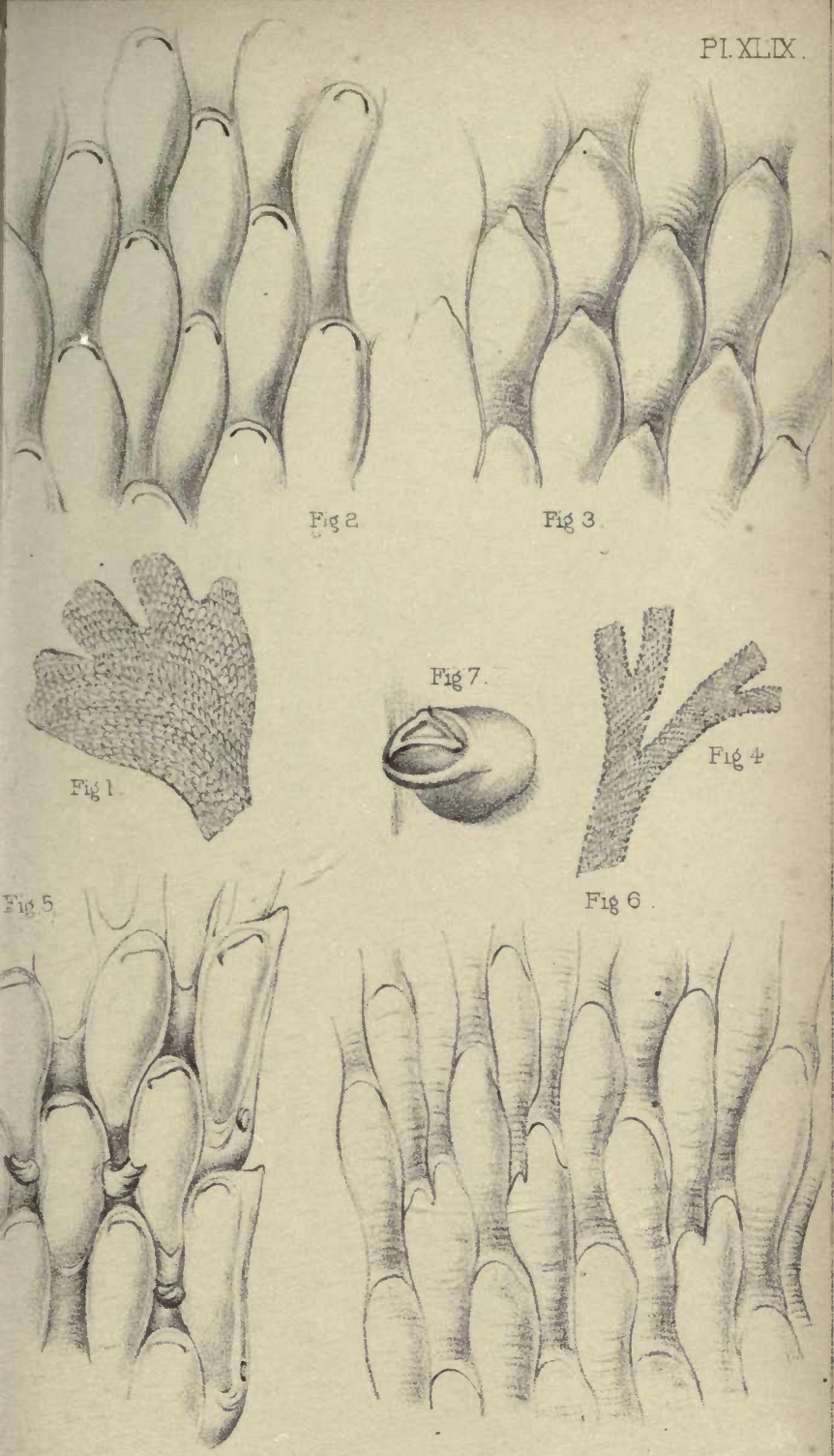


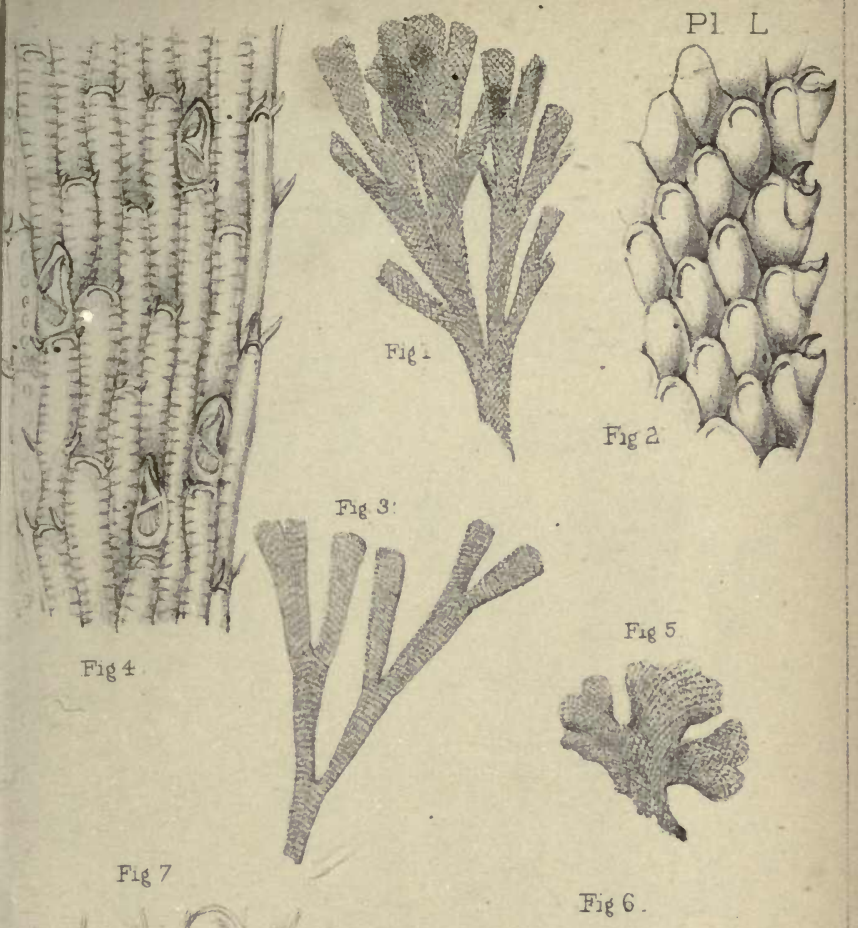




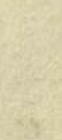



PI. LIII.

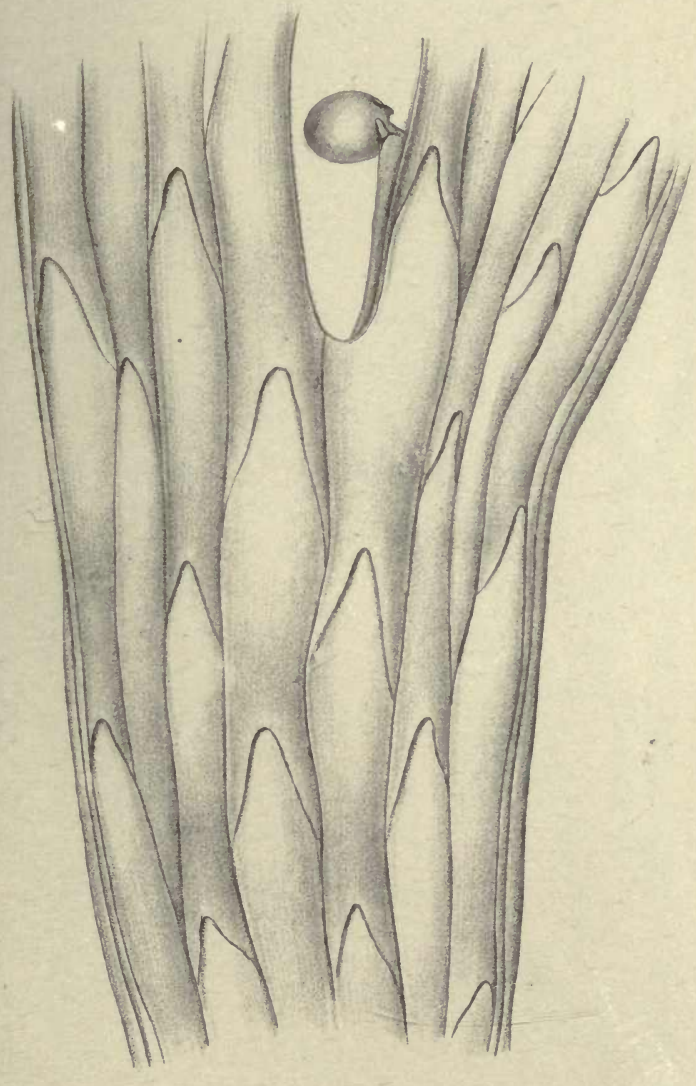

Acamarchis flabellata.

(back.) 

PI. L III .

Fig. 1.

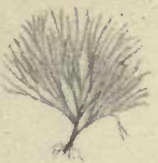

Fig. 2.

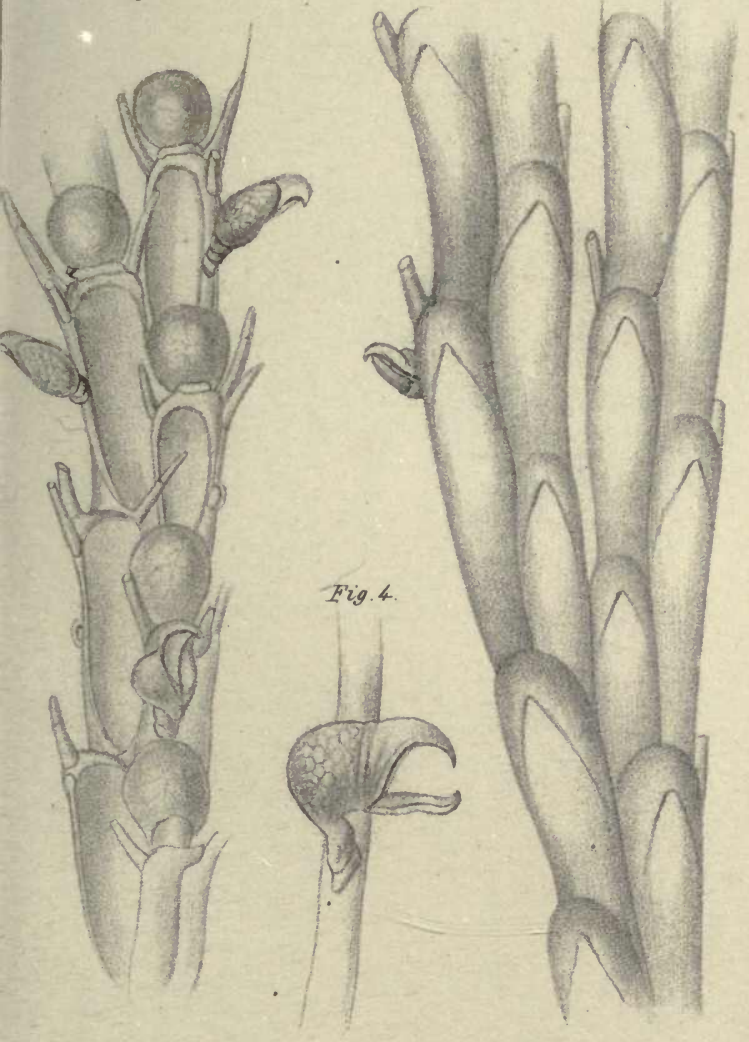

Acamarchis avicularia. 



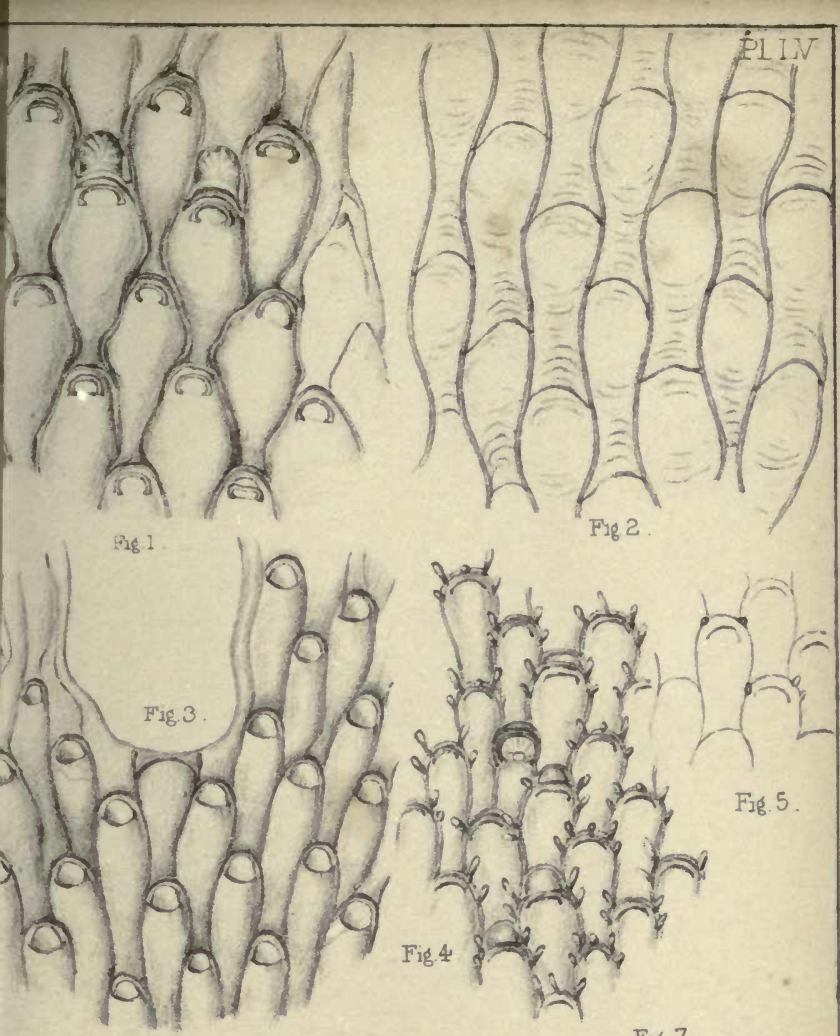

Fig 2
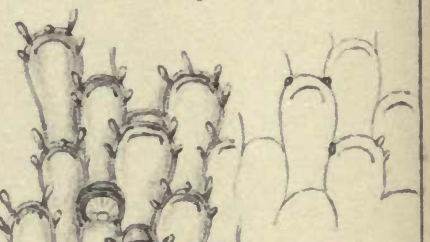

ving ata

No 50 Fis. 5.

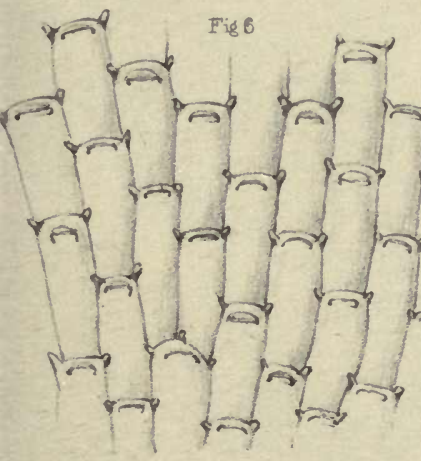

Fig. 7
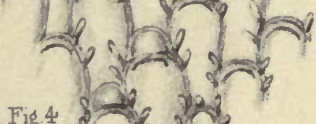

Fig. 4 करो the

$$
\text { ข้า? }
$$

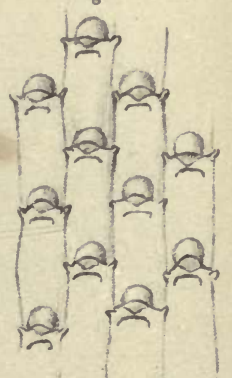





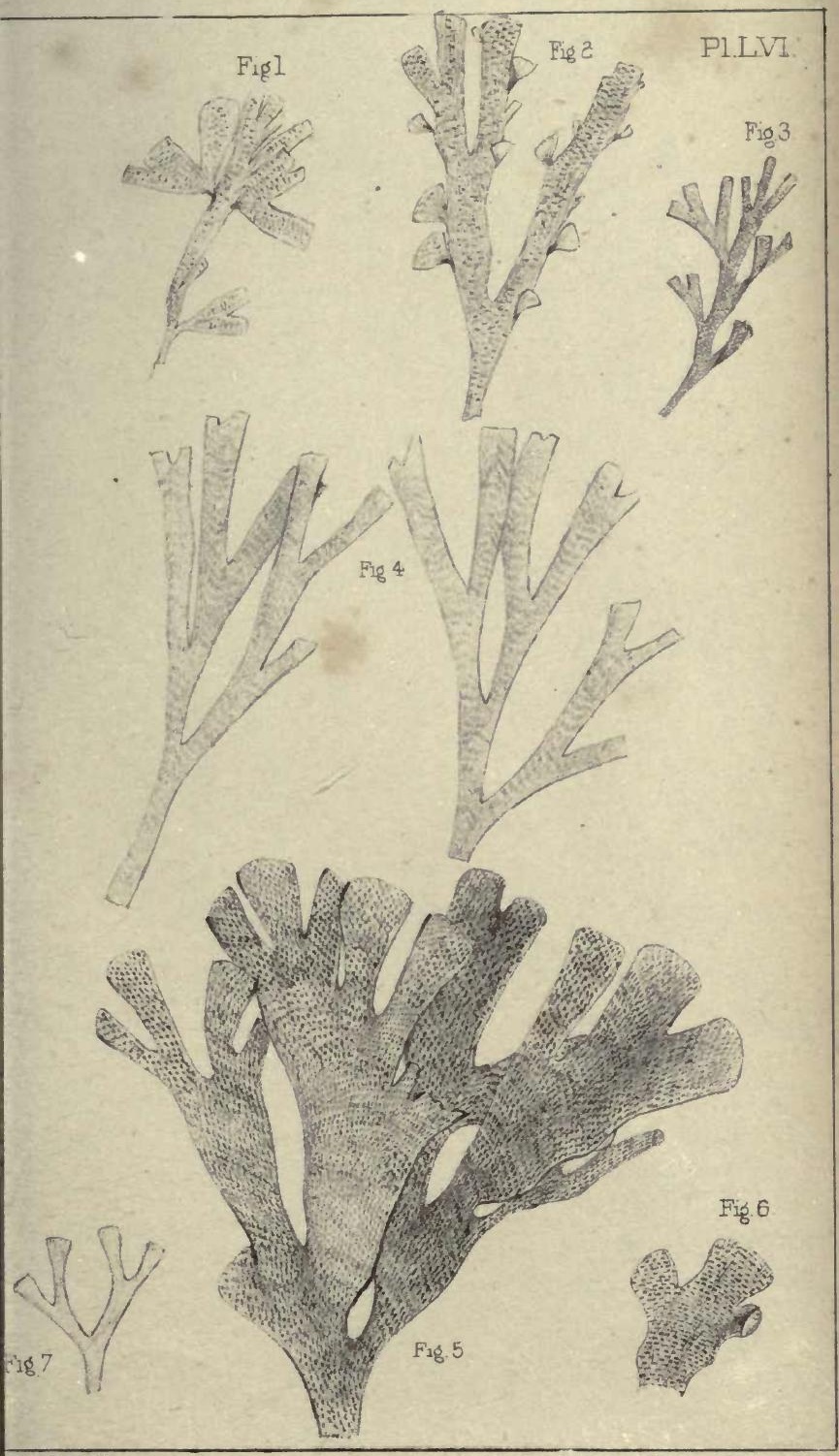

Bust. 1A et Lith.

Fond \& Geospo Iitho graphers, Fatton $Q$ arden 



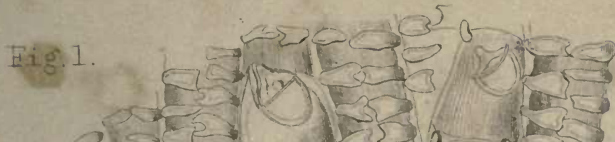

PI. LVII

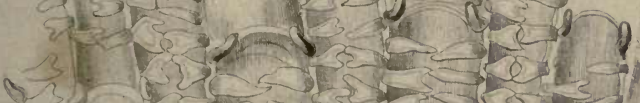

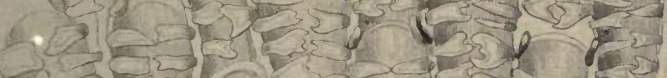

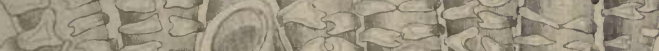

3035 .

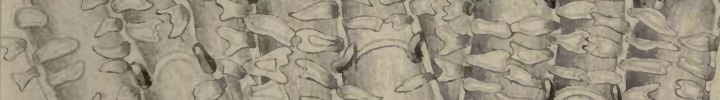

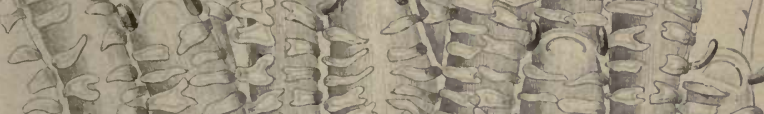

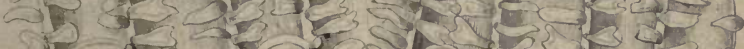

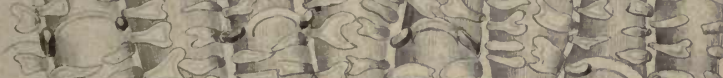

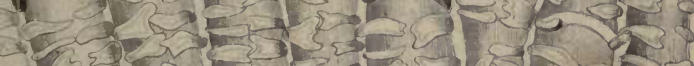

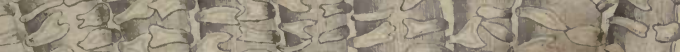

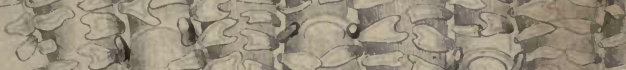

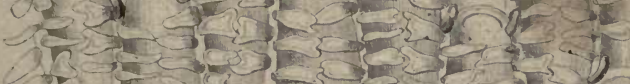

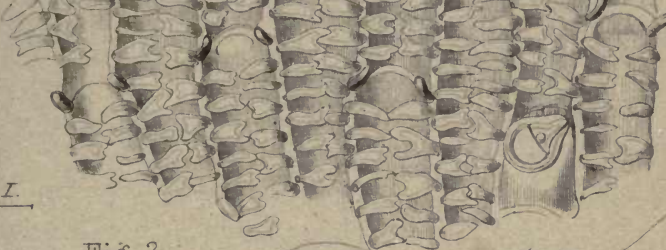

Fig. 2.

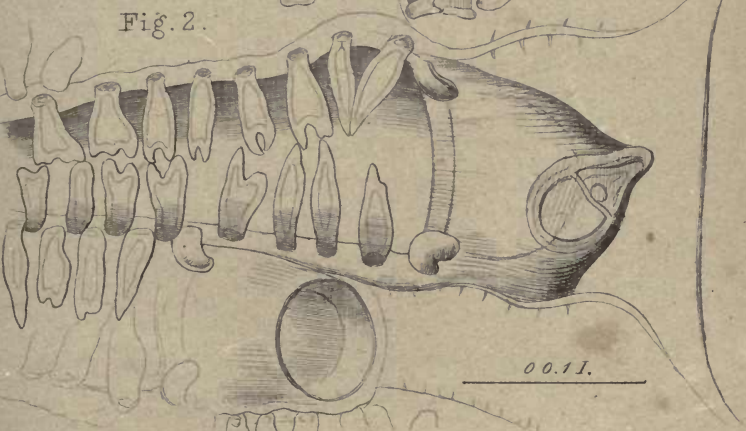





Fig. 1.

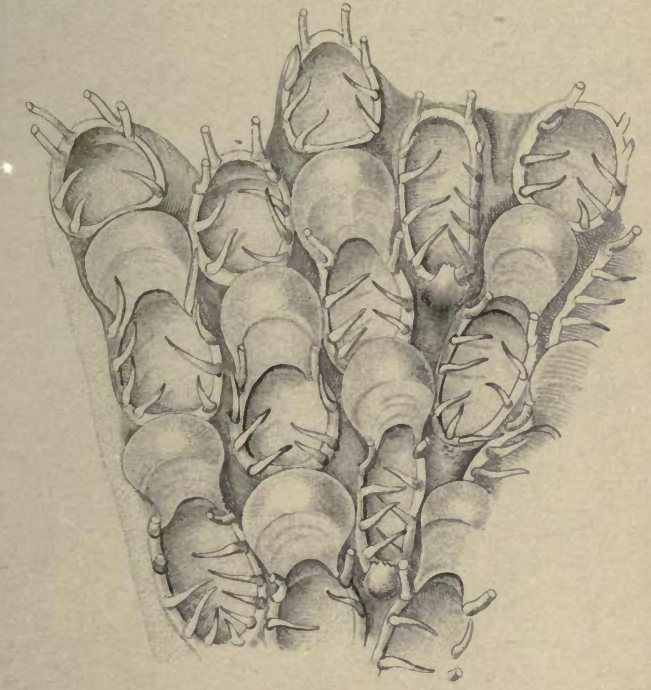

Fig. 2 .

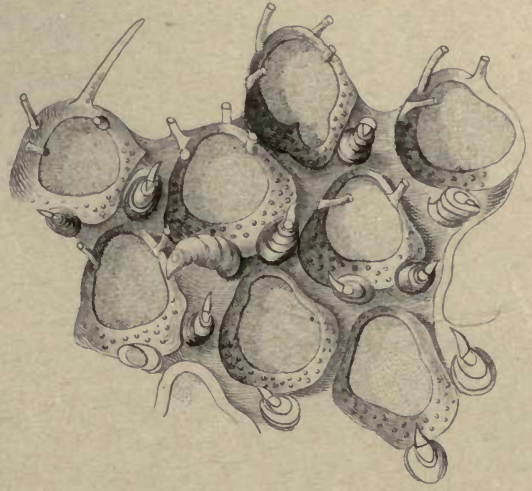

00.1 .1$. 



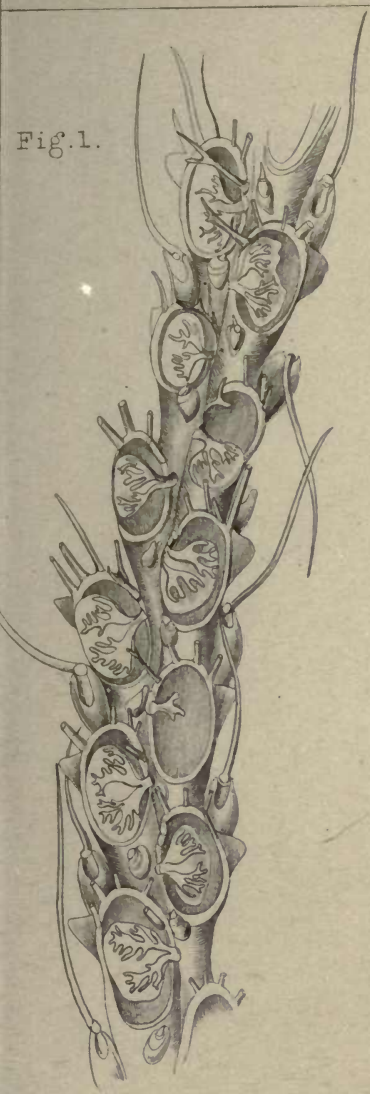

P1. LXII.

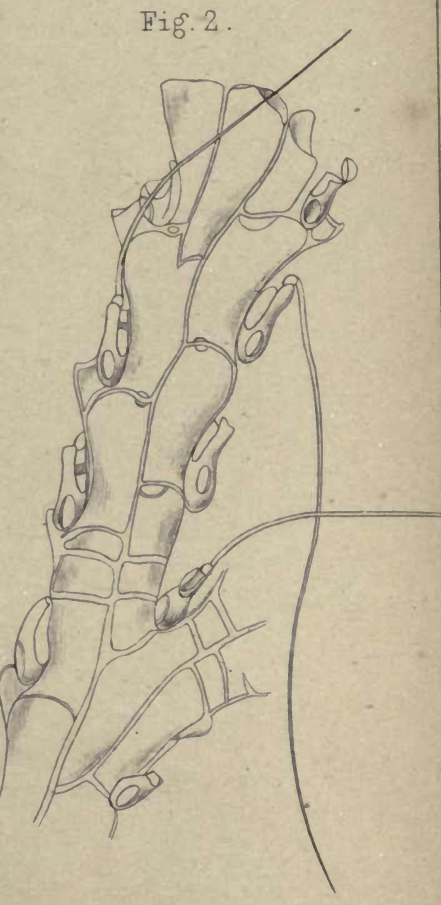

Fig.4.
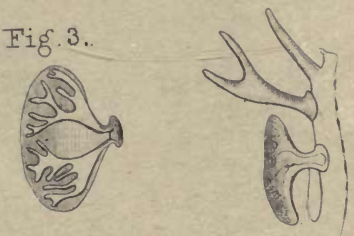

Scrupocellaria cervicornis. 
Pl. IXII.

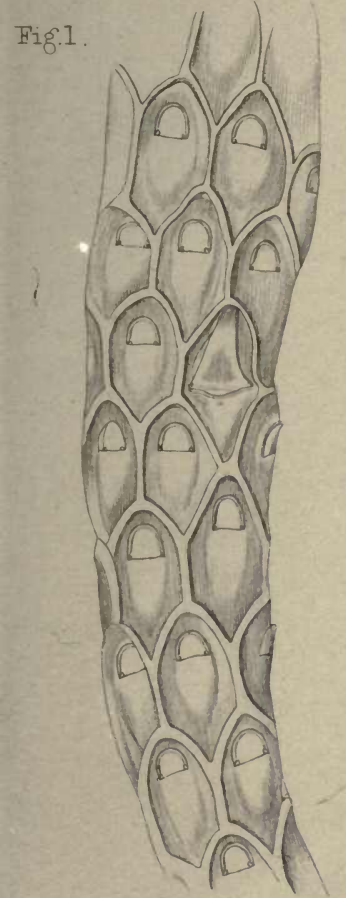

Fig. 2

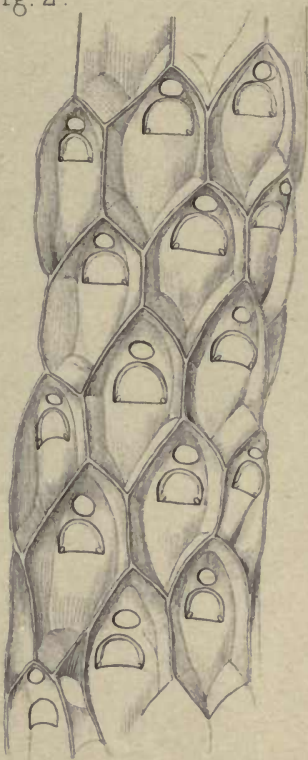

Fiŝ. 3 .

Fig. 5. Fig. 4 .
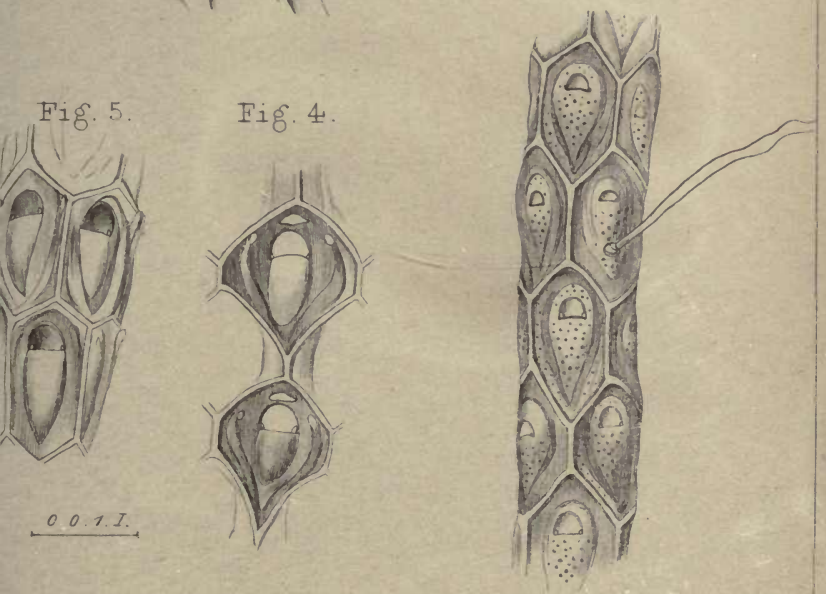


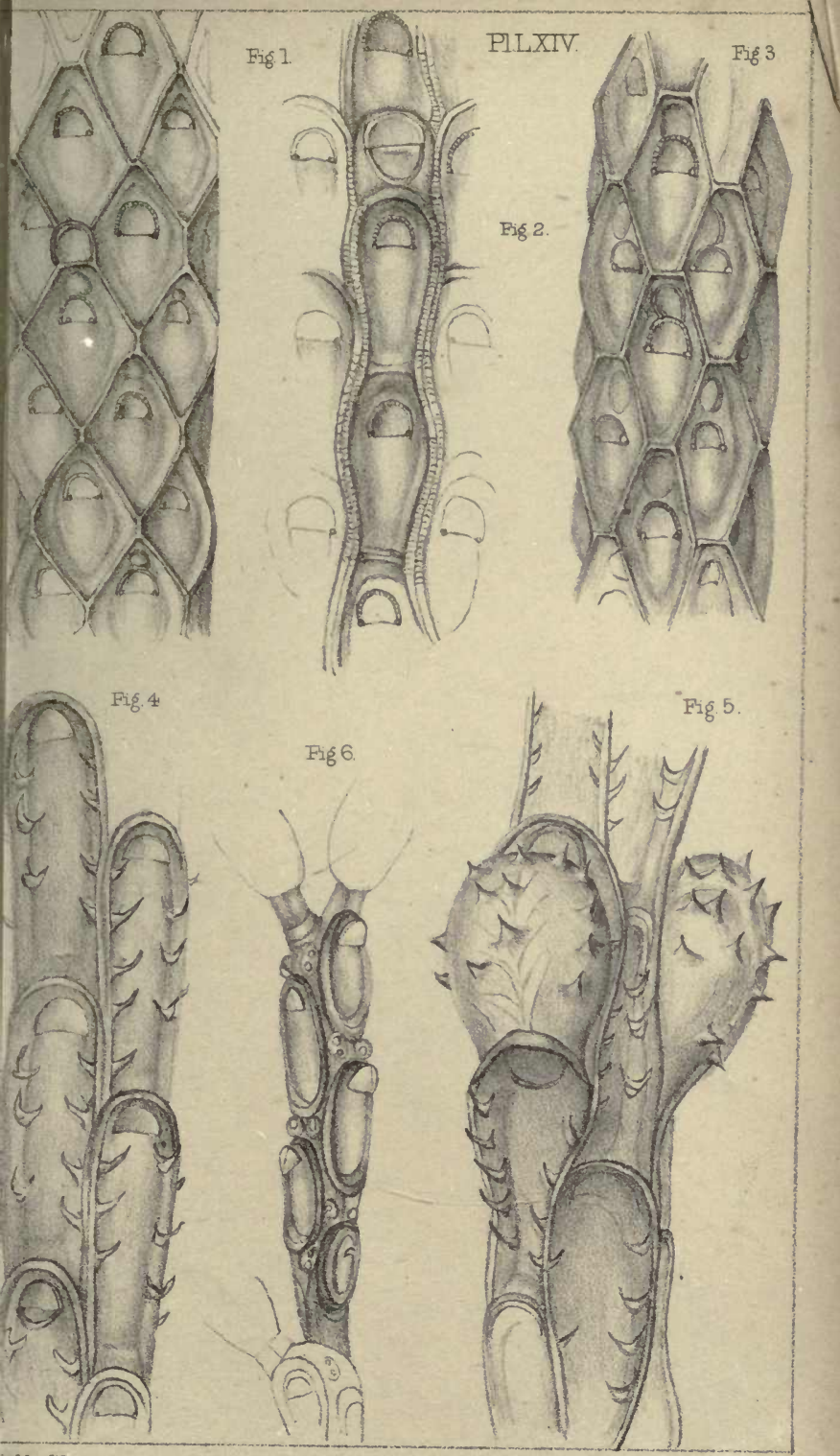

ix, and ot tith 



\section{P1. I.XV}

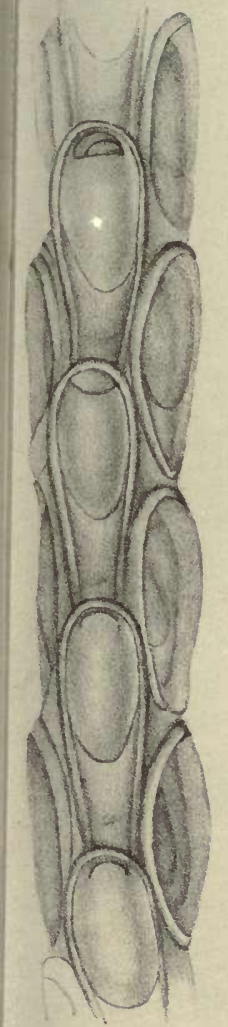

0.07, I

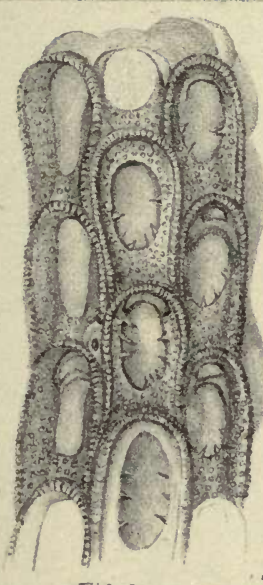

Fiß̨. 2 .

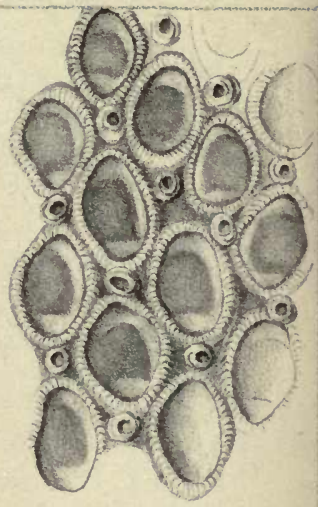

Fig. 3
0. 01.1

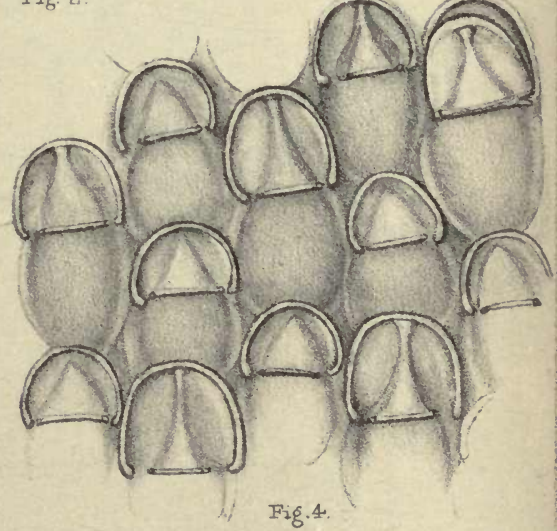

Fig. 6.909

$x^{9}, 190$

61.02-a?

(-) 1 (t)

1.90909

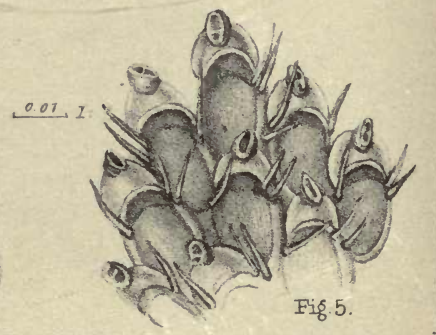




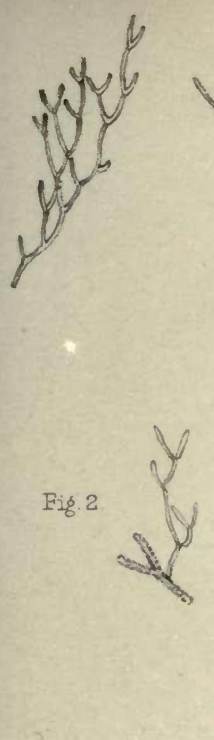

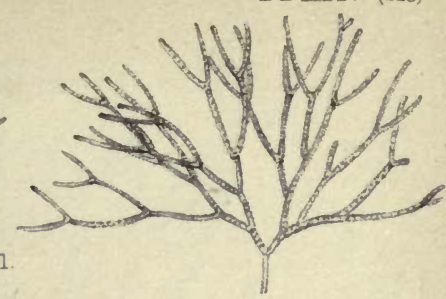

Fig. 1.

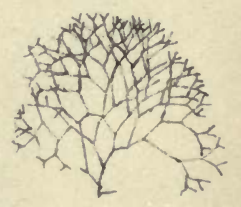

Fig 4

Fig. 3.

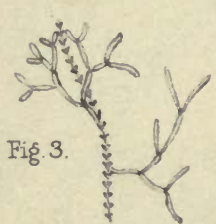

I) 1

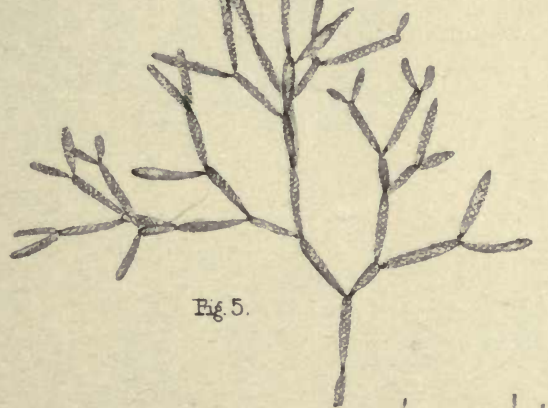

Fif. 5.

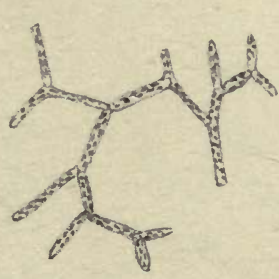

Fig 7.

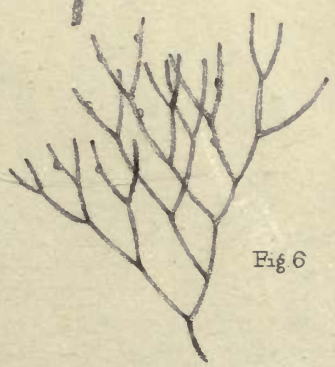




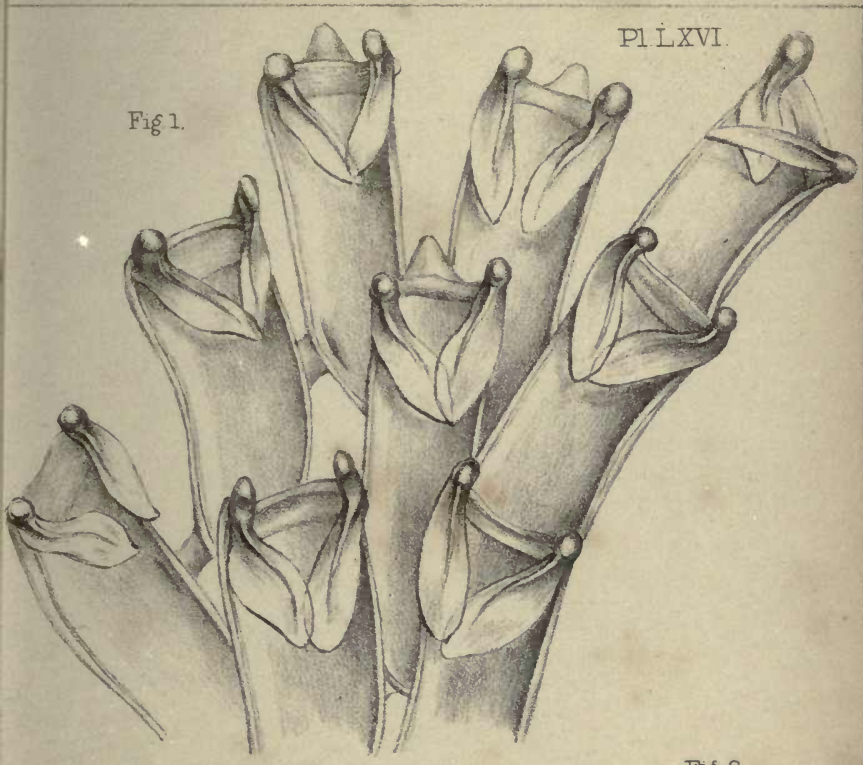

Fig. 2.

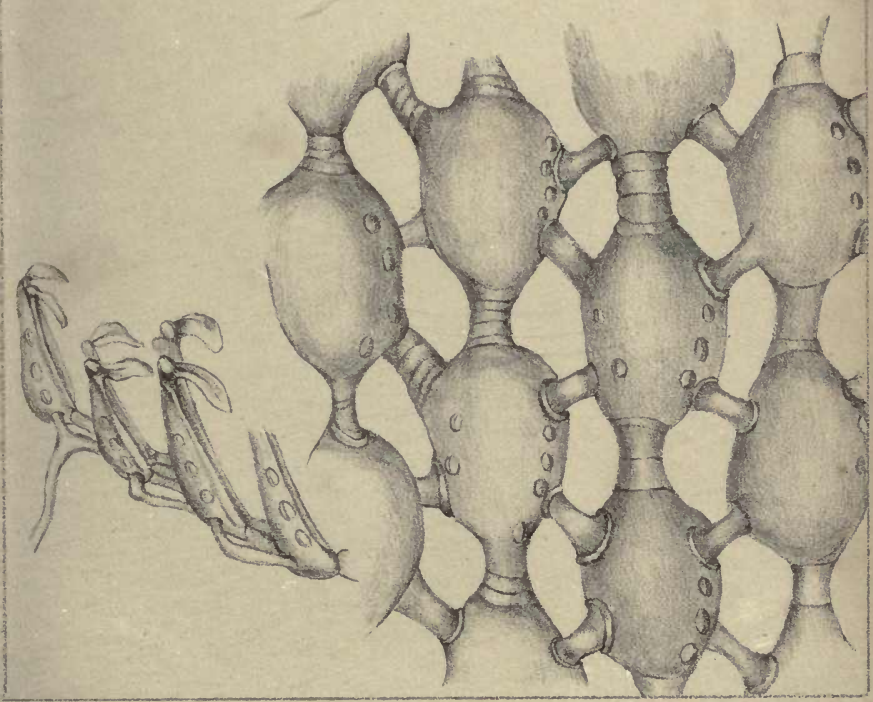

GBunt, del et lith

Fand \& Wert, Inom 54, Detton Garder. 


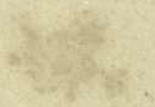



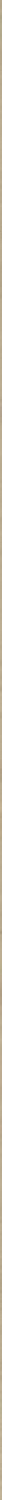




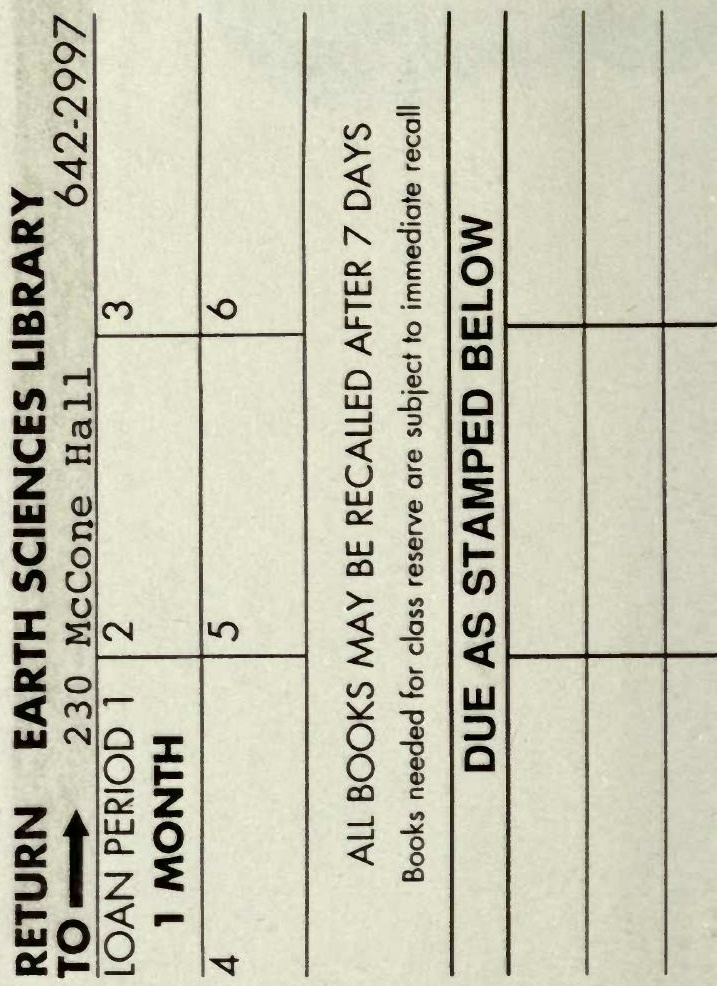


